\title{
Strength grading and selected strength properties of European hardwoods
}

\section{Dissertation}

In partial fulfillment of the requirements for the doctoral degree

„Doctor rerum naturalium“

of the Faculty of Forest Science and Forest Ecology

University of Göttingen

in the Ph.D. program Wood Biology and Wood Technology

of the Georg-August University School of Science (GAUSS)

Submitted by

\section{Philipp Schlotzhauer}

Born in Eisenach, Germany

Göttingen, 2018 

First referee: $\quad$ Prof. Dr. Holger Militz

Department of Wood Biology and Wood Products

Faculty of Forest Sciences

University of Göttingen, Germany

Second referee: $\quad$ Prof. Dr.-Ing. Werner Seim

Department of Timber Structures and Building Rehabilitation

Faculty of Civil and Environmental Engineering

University of Kassel, Germany

Further examiners in the disputation:

Prof. Dr. Dr. h.c. František Hapla

Department of Wood Biology and Wood Products

Faculty of Forest Sciences

University of Göttingen, Germany

Prof. Dr. Andreas Krause

Mechanical Wood Technology, Centre of Wood Science, Department of Biology MIN Faculty

University of Hamburg, Germany

PD Dr. habil. Christian Brischke

Department of Wood Biology and Wood Products

Faculty of Forest Sciences

University of Göttingen, Germany

Date of oral examination: $13^{\text {th }}$ September 2018 

Dedicated to my loving wife Eva-Lotta. 



\section{Acknowledgements}

First, I would like to thank Prof. Dr. Holger Militz, Dr. Susanne Bollmus and Dr. Antje Gellerich for considering me for the position of doctoral candidate in the FNR research group "New markets and applications for native hardwood species", what gave me the opportunity to compose this doctoral thesis. I greatly appreciated their professional expertise as well as the familiar atmosphere within the working group.

For their support in conducting my research, I also want to thank the entire technical staff and primarily Bernd Bringemeier, who helped handle the great number of wood specimens that had to be prepared.

The final manuscript could not have been written without the contributions made by the collaborating bachelor, master and Ph.D. students Philipp Nelis, Fritz Wilhelms, Lukas Emmerich, Georg Behr, Michael Starck, Bernd Lütkemeier, Alexander Ehrmann, Benedikt Wingen, Johannes Persch, Katja Butter, Franziska Hentschel and Jan-Philipp Butz.

In the final stages of my dissertation, Prof. Dr. Dr. h.c. Frantisek Hapla and Dr. Peter Stapel as well as Dr. Susanne Bollmus and Prof. Dr. Holger Militz were a great help by reviewing the manuscript and giving me helpful advice.

I also want to thank Prof. Dr.-Ing. Werner Seim for agreeing to serve as second referee. In this function, he focused my attention on the practical implications of my research results and helped me see them from the point of view of a construction engineer.

Last but not least, I would like to thank my family for supporting me spiritually throughout writing this thesis and my life in general. Especially, I want to thank my loving wife Eva-Lotta, who this thesis is dedicated to. She constantly supported me during the last years and whenever necessary, next to her own studies and motherhood, she took weight off my shoulders.

The research conducted to compile the papers of this dissertation was part of the research project "New markets and applications for native hardwood species [Schaffung neuer Absatzmärkte und Anwendungsfelder für einheimische Laubhölzer unter Anwendung neuartiger Technologien]" (funding code: 22024211). The funding from the German Federal Ministry of Food and Agriculture (BMEL/FNR) is gratefully acknowledged. 


\section{Contents}

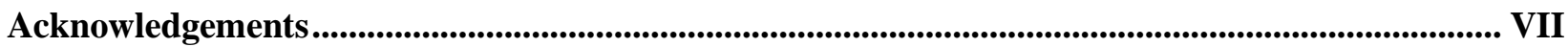

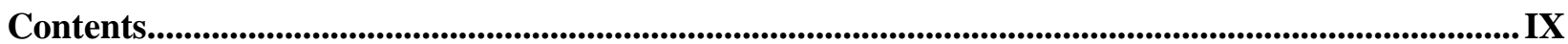

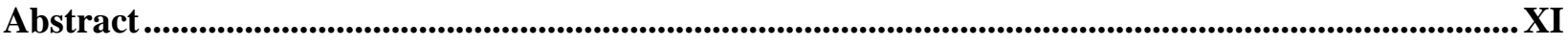

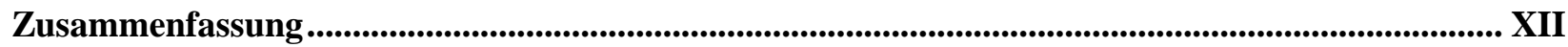

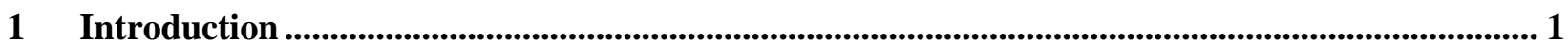

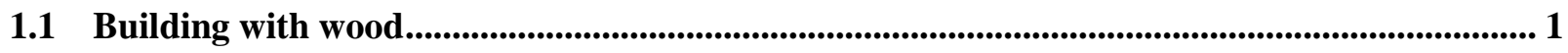

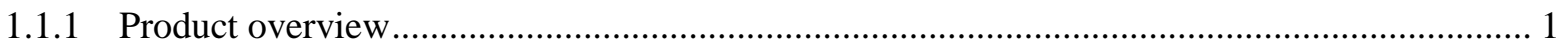

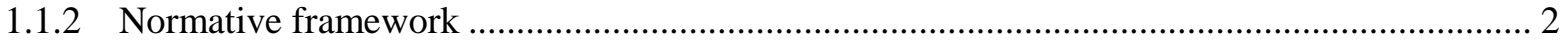

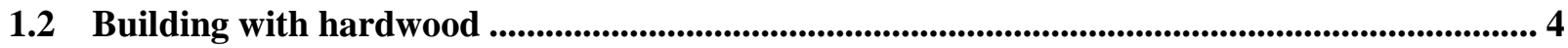

1.2.1 Hardwood resources - availability and use ................................................................. 4

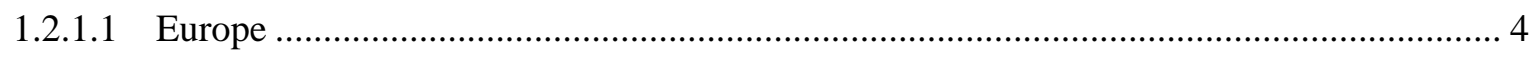

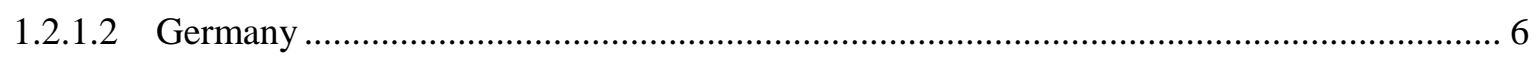

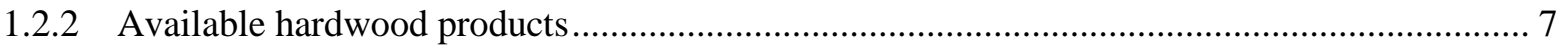

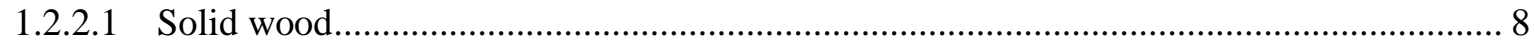

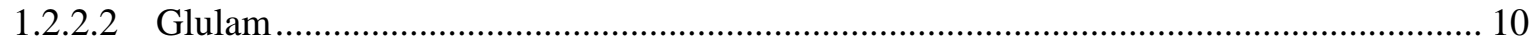

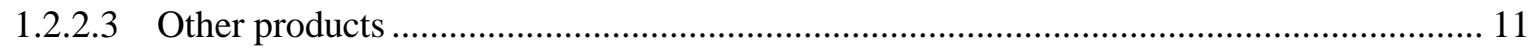

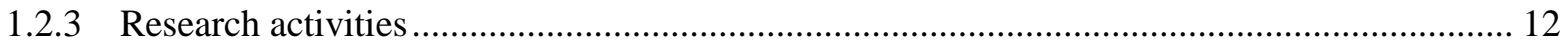

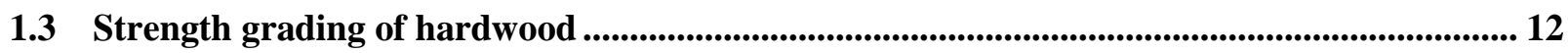

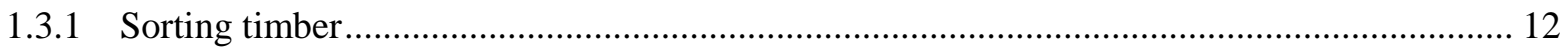

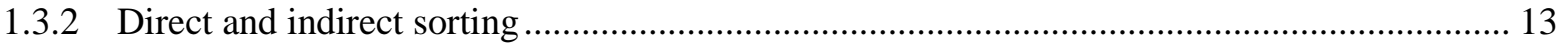

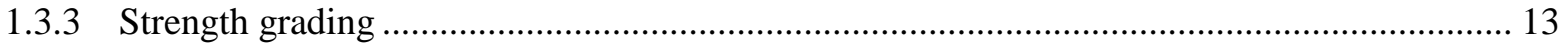

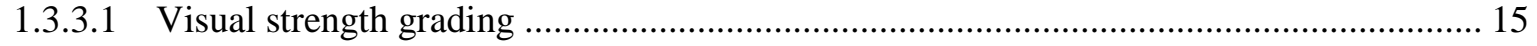

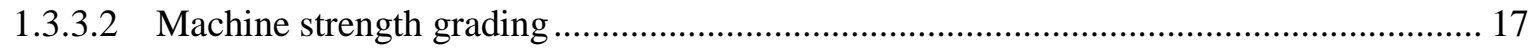

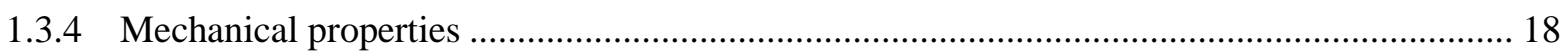

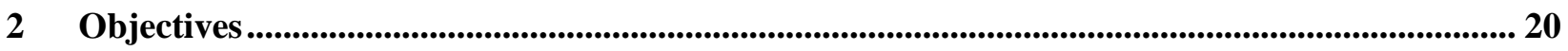

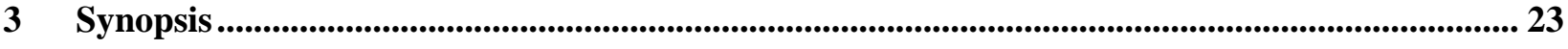

3.1 Hardwoods in construction - challenges along the production and utilization chain (A) ..... 23

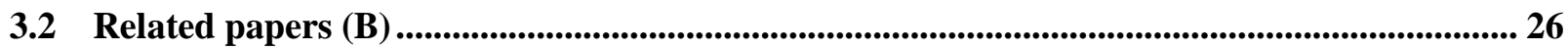




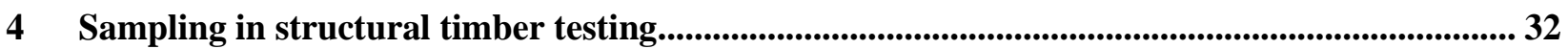

4.1 Definitions and standard specifications.................................................................................... 32

4.2 Sampling in publications..................................................................................................................... 34

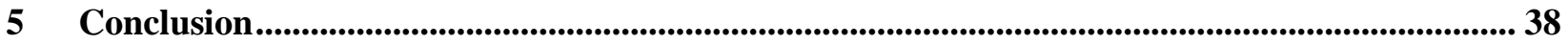

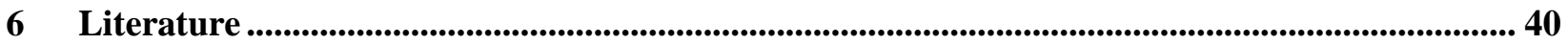

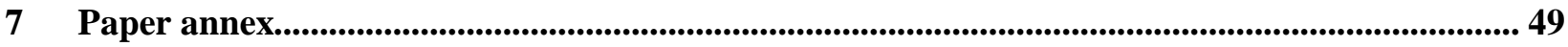

Paper a: Visual and machine strength grading characteristics of six European hardwoods......... 51

Paper b: Analysis of economic feasibility of ash and maple lamella production for glued laminated timber.................................................................................................................... 63

Paper c: Visual and machine strength grading of European ash and maple for glulam

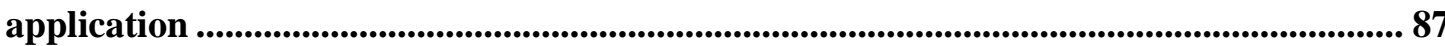

Paper d: Comparison of three systems for automatic grain angle determination on European hardwood for construction use .......................................................................................................... 103

Paper e: Effect of size and geometry on strength values and MOE of selected hardwood

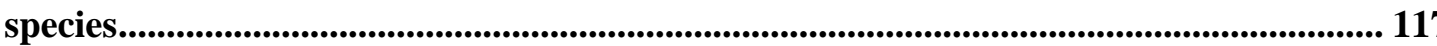

Paper f: Critical discussion of perpendicular to grain tension testing of structural timber case study on the European hardwoods ash, beech and maple

Paper g: Überprüfung der in DIN EN 338 angegeben (Querdruck-)Festigkeits- und Steifigkeitseigenschaften sowie Rohdichten für Buchen-, Eschen- und Ahornholz [Review of EN 338 characteristic (perpendicular to grain compression) strength and stiffness as well as density values for European beech, ash and maple wood]

Curriculum vitae 


\begin{abstract}
Since national standing stocks of hardwoods will be rising in central Europe in the future, it is the declared political will to introduce these resources to a higher extent into the building sector. That is why since the turn of the century more and more funds for hardwood research have been made available. This research together with efforts made by private companies has led to a number of European and German technical approvals for hardwood glulam (oak, beech, sweet chestnut, beech LVL). A further result was the inclusion of the hardwood species beech, oak, maple, ash and poplar into the European standard EN 1912, which allows the use of these hardwoods as solid wood product in construction. Nonetheless, a wide-spread use of these products cannot be witnessed at present. One goal of this dissertation was to identify reasons for this development. Next to market driven causes like a still sufficient availability of softwood and high prices of hardwood products, technological reasons (problems) regarding hardwood glulam and solid wood were identified. In the course of this dissertation, it was aimed to answer some of these technical questions, in order to work towards a more reliable and cost reduced (etc.) hardwood construction product.
\end{abstract}

First, the market and standard situation was identified and put together. The subsequent research was designed to create answers to pressing questions connected to the work field of strength grading. Here, a raised improvement potential was seen. For the six European hardwood species oak, beech, ash, maple, lime and birch the distribution of sawn wood characteristics (of a typical, market available assortment) were determined and the timber availability examined, in order to evaluate the suitability of the species for a wider use in construction. For the species ash and maple, a yield analysis from round wood sections to sorted glulam lamellas was carried out, which pointed out the need for an improved sawing technique (incl. sawing pattern), a faster drying technology and optimized strength grading. When it comes to strength grading, the grain angle is highly correlated with the final tensile strength of the glulam lamella. According to experts on the field, it is not possible to determine the grain angle on hardwoods in a non-destructive way. In the course of this dissertation, it was proven that for five of the six above-mentioned hardwood species (except ash) it is possible to determine the grain angles by machine use. Also, in this field of work falls the topic "size effect", which was examined for bending, tension and compression parallel to grain (for all six species). Mechanical properties in tension and compression testing perpendicular to grain were examined for ash, maple and beech construction timber. In addition, tension tests on glulam lamellas were carried out and the results correlated with the sorting results. These experiments revealed the unused potentials (in standard strength values) of some of the hardwoods, but also pointed out the difficulties in raising the final yield (i.e. lower production costs). 


\section{Zusammenfassung}

Die Laubholzvorräte werden in Mitteleuropa in Zukunft ansteigen und es ist erklärter politischer Wille, diese Ressourcen im Bauwesen stofflich zu nutzen. Seit der Jahrtausendwende wurden deshalb mehr und mehr öffentliche Mittel für die Laubholzforschung zur Verfügung gestellt. Diese Forschung hat zusammen mit Bemühungen privater Unternehmen zu einer Reihe von europäischen und deutschen technischen Zulassungen für Brettschichtholz aus Laubholz (Eiche, Buche, Edelkastanie, Buche Furnierschichtholz) geführt. Ein weiteres Ergebnis war die Aufnahme der Laubholzarten Buche, Eiche, Ahorn, Esche, Pappel und Edelkastanie in die europäische Norm EN 1912, die die Verwendung dieser Laubhölzer als Vollholz im Bau ermöglicht. Eine weit verbreitete Verwendung dieser Produkte ist derzeit jedoch nicht $\mathrm{zu}$ beobachten. Ein Ziel dieser Dissertation war es, die Produktions- und Wertschöpfungsketten von LaubKonstruktionsholz zu analysieren und Probleme bzw. Optimierungspotentiale entlang dieser zu identifizieren. Zunächst wurde hierfür die Markt- und Normensituation identifiziert und zusammengestellt. Ziel der im Anschluss durchgeführten Versuche war es drängende Fragestellungen in der Produktions- und Wertschöpfungskette von Laubholzprodukten für die konstruktive Anwendung zu beantworten. Besonderes Augenmerk wurde auf das Arbeitsfeld Festigkeitssortierung gelegt, da hier ein deutliches Optimierungspotenzial gesehen wurde. Für die sechs europäischen Laubholzarten Eiche, Buche, Esche, Ahorn, Linde und Birke wurde die Verteilung der Schnittholzmerkmale (eines marktüblichen Sortiments) ermittelt und die Holzverfügbarkeit untersucht, um die Eignung der Holzart für eine breitere Verwendung im Bauwesen zu bewerten. Für Esche und Ahorn wurde eine Ausbeuteanalyse vom Langholzabschnitt bis zur sortierten BSH-Lamelle durchgeführt. Diese Untersuchung verdeutlichte die Notwendigkeit einer verbesserten Sägetechnologie, einer schnelleren Trocknungstechnik und einer angepassten Sortierung. Ein wichtiges Schnittholz-Sortiermerkmal ist die sogenannte Faserneigung. Diese korreliert stark mit der Zugfestigkeit von BSH-Lamellen. Nach Ansicht von Experten auf dem Gebiet ist es nicht möglich den exakten Faserwinkel für Laubschnittholz zerstörungsfrei zu bestimmen. Im Rahmen dieses Projektes wurde nachgewiesen, dass es außer für Eschenholz für alle oben genannten Laubholzarten möglich ist, den Faserwinkel maschinell zu bestimmen. Abhängig von der Sortierung treten bei den Festigkeiten und Steifigkeiten der Holzbauteile Größeneffekte auf. Diese wurden für alle sechs oben genannten Holzarten im Biege-, Zug- und Druckversuch parallel zur Faser untersucht. Zusätzlich wurden im Druck- und Zugversuch quer zur Faser Festigkeiten, Steifigkeiten und Versagensmodi für Ahorn, Esche und Buche evaluiert. Weitere Materialkennwerte wurden in Zugversuchen parallel zur Faser an BSH-Lamellen ermittelt und

diese mit visuellen und maschinellen Sortierergebnissen korreliert. Diese Experimente zeigten die zum Teil ungenutzten Potentiale bezüglich Festigkeiten und Steifigkeiten einiger Laubhölzer, aber auch die Schwierigkeit die Materialausbeute zu erhöhen. 


\section{Introduction}

\subsection{Building with wood}

The use of wood as building material goes back to the beginning of mankind. The more working respectively machining options were available, the more applications for wood were possible. Virtually any building structure can be constructed with wood. For centuries, wooden structures have been part of residential buildings and bridges. During the middle ages, mainly oak solid wood was used for framework constructions in central Europe. Architectural witnesses of these times still exist. In an impressing manner, these buildings prove the applicability of the material - regarding durability and strength properties. Before the invention of steel, wood was the only building material, which was able to carry high tension and bending loads. Along with the industrialization of the $19^{\text {th }}$ century, the use of steel and later steel in combination with concrete forced wood out of many applications. With the invention of glulam in 1906 by Otto Hetzer, timber engineering gained new momentum (Lennartz and Jacob-Freitag 2016). The new, glued products were mainly produced form spruce and fir wood, since these trees were widely available and gluing and machining of these species is least complicated (Aicher 2014). In modern timber engineering, hardwoods like oak played nearly no role. It was only at the turn of the century, when the works of Glos and Näher (2005) as well as Glos and Lederer (2000) eased the use of oak as construction timber according to current harmonized European regulations.

\subsubsection{Product overview}

Present-day wood-based building products can be classified into the following groups (Table 1), whereby certain special products might fall in more than one of the listed groups. 
Table 1: Wood-based building products.

\begin{tabular}{|c|c|}
\hline Building product group & Product examples \\
\hline Roundwood & Poles \\
\hline \multirow[t]{5}{*}{ Sawn wood (timber) products } & Solid wood (construction timber) \\
\hline & Finger jointed solid wood (construction timber) \\
\hline & Glulam (glued laminated timber) \\
\hline & CLT (cross-laminated timber) \\
\hline & Etc. \\
\hline \multirow[t]{2}{*}{ Veneer-based products } & LVL (laminated veneer lumber) \\
\hline & Plywood \\
\hline \multirow[t]{4}{*}{ Particle-based products } & OSB (strands) \\
\hline & Particleboard \\
\hline & Insulation material (wood shavings) \\
\hline & Scrimber \\
\hline \multirow[t]{3}{*}{ Fiber-based products } & HDF \\
\hline & MDF \\
\hline & Insulation material (Paper and wood fiber insulation) \\
\hline \multirow[t]{7}{*}{ Others (mixed) } & Windows \\
\hline & Doors \\
\hline & Flooring \\
\hline & Furniture \\
\hline & Claddings/facades \\
\hline & Deckings \\
\hline & Etc. \\
\hline
\end{tabular}

According to Sathre and Gustavsson (2009), in the construction of German one and two family houses, wood only makes up $10 \%$ of the consumed material volume. In other regions of the world, shares are higher. In Scandinavia this share is $80-85 \%$ and in the USA even $90-94 \%$.

\subsubsection{Normative framework}

The normative framework of wood use in construction is exemplarily illustrated for sawn wood products in Figure 1. 
Products

(solid wood, finger jointed solid wood, glulam, CLT, etc.)

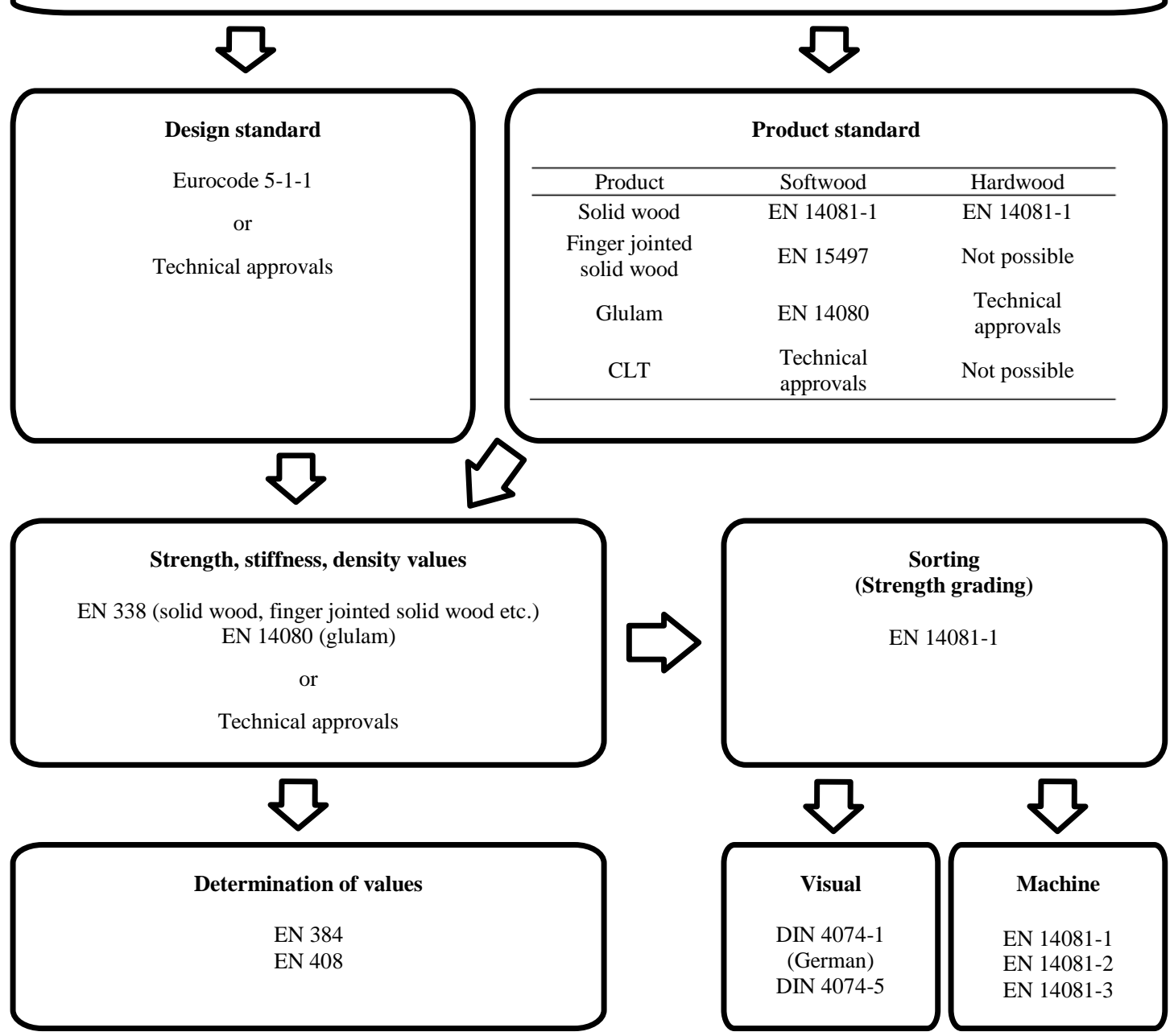

Figure 1: Normative framework (without years) of wood-based products for load bearing applications (as of January 2018).

There is a so-called product standard for each wood-based product, which regulates the production of the building product. Here also product control and labelling are specified. It has to be distinguished between soft- and hardwoods. While for both soft- and hardwoods solid construction timber is produced in accordance with the harmonized European standard EN 14081-1 (2016), finger jointed construction timber can at present only be produced from softwoods (EN 15497 2014). For glulam, the harmonized European standard EN 14080 (2013) also only regulates the softwood product. At the moment, hardwood glulam can only be produced after technical building approvals (European and national). The European design standard Eurocode 5-1-1 (EN 1995-1-1 2010) gives planners respectively engineers and architects the rules for planning and calculating wooden, load bearing structures. The semi-probabilistic safety concept of the design standard ensures that during the erection phase and the intended period of use, the planned structure is able to withstand all possible external forces unharmed with a reasonable reliability. Calculation strength, 
stiffness and density values are provided either by EN 338 (2016) for solid soft- and hardwood and finger jointed solid wood (only softwood) or by EN 14080 (2013) for softwood glulam. The values are put together to so-called "strength classes". The EN 338 (2016) distinguishes between softwood strength classes, which are abbreviated with $\mathrm{C}$ for coniferous, and hardwood strength classes, which are abbreviated with $\mathrm{D}$ for deciduous. Poplar wood is assigned to C-classes, since its characteristics profile is similar to that of softwoods. Different wood species are assigned to different strength classes. Furthermore, since wood from the same species but different origin can be characterized by differences in elasto-mechanic properties, it can also be assigned to different strength classes. Also, different strength grading schemes of the same species can lead to different characteristics profiles. In many of the European countries over the time separate national visual strength grading standards have been developed, which fulfil the requirements of EN 14081-1 (2016) for visual strength grading. In Germany, for example, the DIN 4074-1 (2012) is the visual sorting (strength grading) standard for softwoods (S-classes) and DIN 4074-5 (2008) for hardwoods (LS-classes; poplar included). For species and origins, for which an extensive data set respectively long-term experience with their use is available, EN 1912 (2013) assigns national visual sorting classes to strength classes according to EN 338 (2016). EN 14081-1 (2016) gives requirements, which have to be fulfilled by machine strength grading systems, so that they can also be assigned to EN 338 (2016) strength classes. Strength, stiffness and density values for an allocation of a wood sample (set of specimens) to a strength class are to be determined according to EN 384 (2016). Here, general instructions are given on sample collection, test procedure and conditions as well as the calculation of "characteristic values". For further test instructions (e.g. span length, test speed, length-width-height ratios, etc.) EN 384 (2016) refers to EN 408 (2012). Hardwood glued laminated timber (glulam) as well as softwood cross-laminated timber (CLT) are not regulated by harmonized European standards yet. They are produced according to national or European technical building approvals (ETA). Such approvals also include design specifications and values (strength, stiffness, density) as well as strength grading additions.

\subsection{Building with hardwood}

\subsubsection{Hardwood resources - availability and use}

\subsubsection{Europe}

National forest inventories give an overview of the forest resources potentially available for material or energetic use. The actual use of the resource wood is hard to quantify and published figures can only be seen as rough estimates (Sauter 2016). Data of felling or selling volumes and assortments have to be

gathered from forest owners. Data from small, private-owned forests is often not available. Also fuel wood removals are often not listed in official statistics (FOREST EUROPE 2015).

Kleinschmit (2012) analyzes Eurostat data and states that the EU 27 countries are covered by 176 million hectares of forest. $38 \%$ of that area is covered with hardwood tree species. This share is very different for different European countries. While in Germany the share of hardwood cover is with $29 \%$ low, it is high in France $(63 \%)$ and highest in Croatia and Hungary (over $80 \%$ ). Northern European countries are mainly stocked with softwood tree species. The further south the European country is located, the higher the hardwood share gets (see Figure 2). 


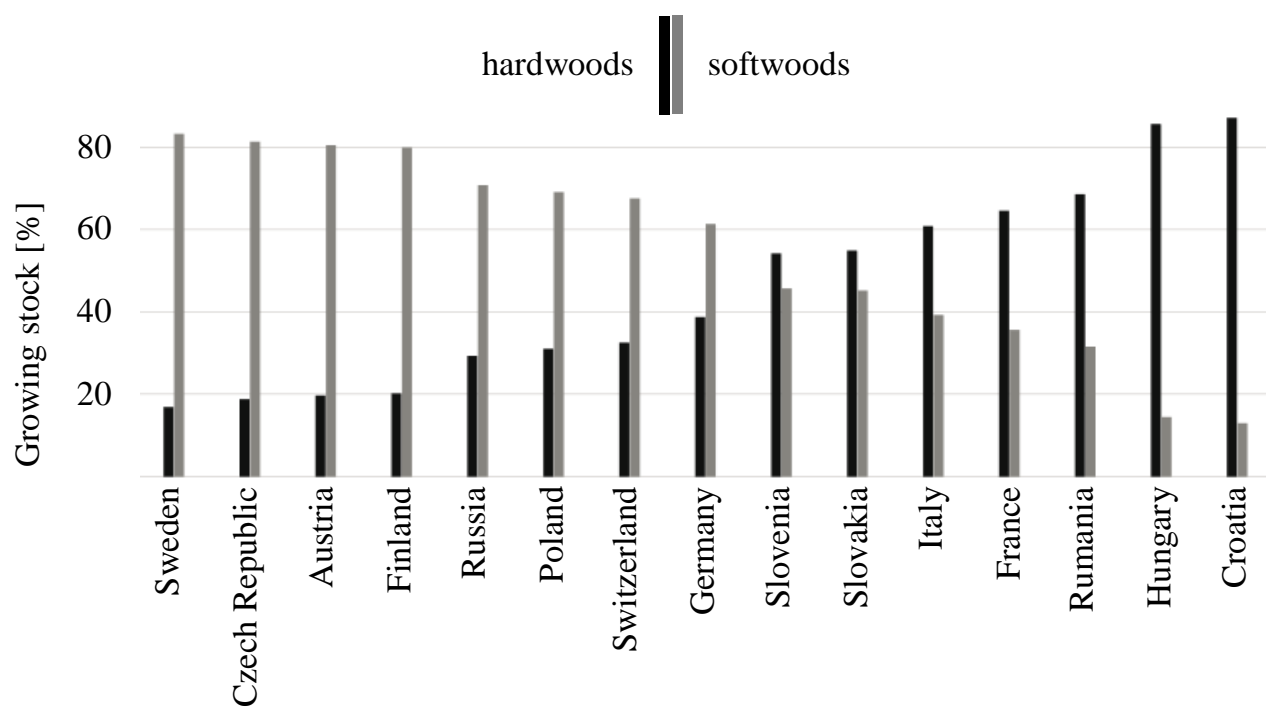

Figure 2: Growing stock in selected European countries separated after hardwood and softwoods tree species (Isopp 2016, translasted).

Separate statistics of the Food and Agriculture Organization of the United Nations (FAO) and the European Union (EU) show, how rough round wood production estimates are. The FAO gathers data on the Europe-wide round wood production. For its report of the year 2015 (FOREST EUROPE 2015), 38 countries ( $60 \%$ of total forest area) have reported their productions. According to the report, in 2010 these countries removed in total 407 million $\mathrm{m}^{3}$ of round wood from their forests. Data on the share of hardand softwoods are not part of the report. The European Union (2017) estimates a round wood production of the $28 \mathrm{EU}$ member countries of 427 million $\mathrm{m}^{3}$ in 2010. The discrepancy between the estimated production of the 28 EU-countries with 427 million $\mathrm{m}^{3}$ and 38 European countries with 407 million $\mathrm{m}^{3}$ is clear.

Nonetheless, according to European Union (2017), around $32 \%$ of the produced round wood was hardwood. The produced sawn wood volume amounted for about one fourth of the round wood volume. Kollert and Lebedys (2012) estimate that in 43 European countries approximately $10 \%$ of the total sawn wood production is hardwood.

More robust data than FAO or European Union data, especially on the available hardwood resources for building applications, was gathered by the so-called "EU HARDWOODS project", in which national forest inventories and felling statistics were reanalyzed (Sauter 2016). Here for the Central European countries Austria, France, Germany and Slovenia the available hardwood timber resources were quantified. Sauter (2016) summarizes that in the four analyzed countries the availability of only the main hardwood species beech and oak account for 2.2 billion $\mathrm{m}^{3}$ (standing stock). For comparison, the standing stock of spruce and pine for Germany and France is indicated with 2.7 billion $\mathrm{m}^{3}$. The majority of hardwoods show constant or even increasing standing stocks. For the hardwood species ash, though, the standing stock is expected to decline due to the ash dieback disease. Accordingly, the harvest volumes are expected to rise in the near future.

Despite national differences, the majority of publications on the matter stress the divergence between a high and constantly rising availability of the resource hardwood and its utilization - especially the desired material use (Krackler et al. 2010; Kleinschmit 2012; Weimar and Seintsch 2012). Individual national 
figures show that the utilization and here especially the material utilization of softwoods is predominant. In Switzerland, for example, in 2008 hardwoods made up about $29 \%$ of the total raw wood use. The share of hardwoods in the Swiss sawn wood and veneer production was only $11 \%$ (Krackler et al. 2010). In France, this share was with $17 \%$ higher, but still low compared to a hardwood forest cover of $63 \%$ of the total forest area (Kleinschmit 2012). In Germany, the hardwood share in the total sawn wood (and veneer) volume was with approximately $4 \%$ vanishingly small (Weimar and Seintsch 2012).

\subsubsection{Germany}

The Third German National Forest Inventory revealed that the total forest area of 11,419,124 hectares covers $32 \%$ of the national territory. $43 \%$ of the forest area is stocked with hardwoods. This implies an increase of $7 \%$ in ten years (2002 - 2012) compared to the Second German National Forest Inventory. The softwood share went down approximately $4 \%$ in the same period (Federal Ministry of Food and Agriculture 2014). This development is due to forest-political decisions, which favor a hardwood-oriented shift in forest structure respectively silvicultural practice (Seintsch and Rosenkranz 2014). In the inventory, the broadleaved tree species are sorted into four so-called "tree species groups", for which also the stocked forest area (in hectares) and the growing stock is given (Federal Ministry of Food and Agriculture 2014). Table 2 summarizes the inventory results.

Table 2: Selected results from the Third German National Forest Inventory (Federal Ministry of Food and Agriculture 2014).

\begin{tabular}{|c|c|c|c|c|}
\hline \multirow{2}{*}{ Species group } & \multicolumn{2}{|c|}{ Stocked forest land } & \multicolumn{2}{|c|}{ Growing stock } \\
\hline & [hectares] & [\% of total] & {$\left[1000 \mathrm{~m}^{3}\right]$} & [\% of total] \\
\hline$\overline{\text { Oak }}$ & $1,129,706$ & 10.38 & 361,231 & $\overline{9.86}$ \\
\hline Beech & $1,680,072$ & 15.43 & 635,257 & 17.34 \\
\hline $\mathrm{ALH}^{*}$ & 769,578 & 7.07 & 204,369 & 5.58 \\
\hline $\operatorname{ALN} * *$ & $1,147,904$ & 10.54 & 219,712 & 6.00 \\
\hline Sum of broadleaved tree species & $4,727,260$ & 43.42 & $1,420,570$ & 38.78 \\
\hline Total (conifers and broadleaved) & $10,887,990$ & $\overline{100.00}$ & $3,662,972$ & $\overline{100.00}$ \\
\hline
\end{tabular}

*ALH = other broadleaved tree species with a long lifetime (maple, ash, chestnut, lime, Sorbus aria, Sorbus domestica, black locust, elm); **ALN = other broadleaved tree species with a short lifetime (birch, Surbus torminalis, Sorbus aucuparia, alder, poplar, Prunus spp., willow, wild fruit trees)

For all four hardwood species groups, the forest area grew compared to the Second German National Forest Inventory. With $39 \%$ of the total growing stock hardwoods respectively broadleaved tree species make up a considerable share of the total volume. Beech is the most common hardwood species in German forests, followed by oak. In the species groups ALH and ALN the inventory does not distinguish between the different hardwood species. These species do not occur in pure stands but are mixed in - mostly into beech stands. The so-called WEHAM prediction groups beech, ALH and ALN into one group and states that here in total $41 \%$ are "not-beech" species like ash, maple, birch or alder (Federal Ministry of Food and 
Agriculture 2016). Sauter (2016) reanalyzed the current inventory data and also gives growing stock figures for the species ash $\left(74,700 \mathrm{~m}^{3}\right)$ and sweet chestnut $\left(3,500 \mathrm{~m}^{3}\right)$.

The WEHAM prediction (base scenario) of standing stocks estimates that in the next 35 years the standing stock of hardwoods will rise, due to unused potentials (Weimar and Seintsch 2012). Especially in the species groups ALH, ALN and oak the resource potentials are not exploited (37\%, $35 \%$ and $44 \%)$. The present beech harvests utilize approximately $74 \%$ of the predicted WEHAM potential. A rise of the hardwood use is not expected. That is why these species are seen as alternative for a use in construction as substitution material for softwood (mainly spruce).

In 2011, only $25 \%$ of the total German raw wood use comprised hardwood (Weimar and Seintsch 2012). The majority (approximately $80 \%$ ) of the harvested hardwood was used for energy production. While the total hardwood consumption increased from 2002 to 2010, the material use of the resource went down drastically. While in 2002 hardwoods still made up $15 \%$ of the total German wood material use, in 2010 this value dropped to $8.5 \%$. It is the declared political will of German as well as other Central European countries' authorities to raise the material utilization of the national hardwood resources (Austrian Federal Environment Agency 2014; German Federal Ministry of Food and Agriculture 2017; Swiss Federal Department of Environment 2017).

\subsubsection{Available hardwood products}

Mantau et al. (2013) estimate that in German house building structures only $12.6 \%$ of the total wood consumption comprises native hardwoods. As Figure 3 proves, in load bearing structures (exterior and interior walls, roof and ceiling) hardwoods play a negligible role. Only in floorings high volumes of hardwoods are being used. Also, staircases are mainly constructed from hardwoods.

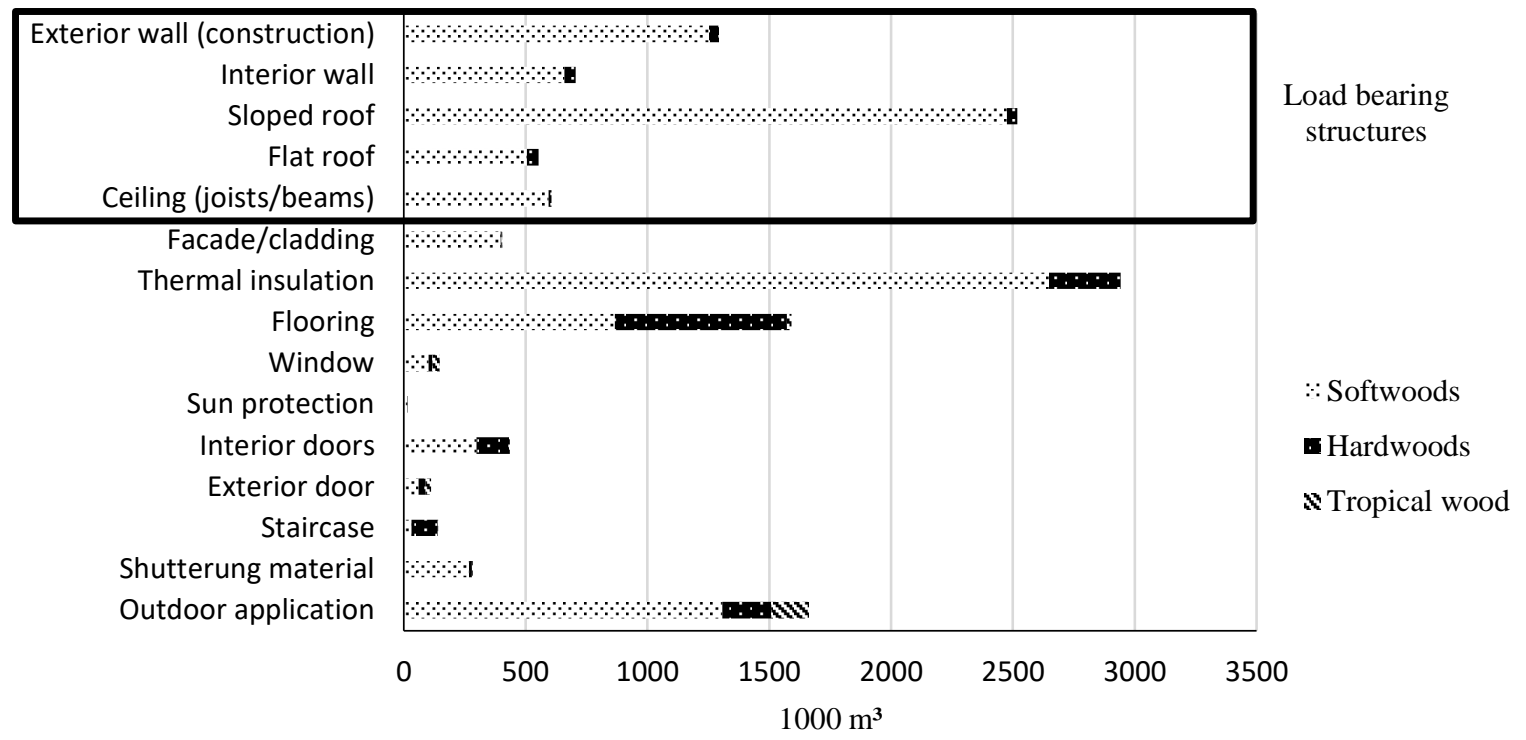

Figure 3: Hard- and softwood (plus tropical wood) distributions and volumes in German building structures separated after trade respectively building part (Mantau et al. 2013, translated). 
Other wooden buildings like bridges are almost entirely construction with spruce solid construction timber or glulam. The following sections list the hardwood products at present (potentially) available on the market for load bearing applications.

\subsubsection{Solid wood}

In general, the European timber construction standard or Eurocode 5 (EN 1995-1-1 2010) allows the utilization of solid hardwood as load bearing element in construction. This structural timber has to be sorted respectively strength graded visually or with a machine system in accordance with EN 14081-1 (2016). The characteristic strength, stiffness and density values have to be in line with one EN 338 (2016) strength class value set for strength, stiffness and density. These values have to be calculated after EN 384 (2016). For some hardwood species, intensive testing respectively the assignment of national visual strength grading classes to EN 338 (2016) strength classes has already been carried out. EN 1912 (2013) lists these assignments. Table 3 shows only the hardwood assignments. 
Table 3: Visual sorting class to strength class assignments for European hardwood structural timber listed in EN 1912 (2013) and two CEN TC124/WG2/TG1 APPROVED GRADING REPORTs (* and ***).

\begin{tabular}{|c|c|c|c|c|c|}
\hline & Bot. Name & Origin & Visual sorting class & (National sorting standard) & $\begin{array}{c}\text { Strength class } \\
\text { (EN 338) }\end{array}$ \\
\hline Ash & $\begin{array}{l}\text { Fraxinus } \\
\text { excelsior }\end{array}$ & Gemany & LS10 or higher & (DIN 4074-5 2008, German) & $\mathrm{D} 40$ \\
\hline \multirow[t]{6}{*}{ Beech } & \multirow[t]{6}{*}{ Fagus sylvatica } & \multirow[t]{2}{*}{ Germany } & LS13 & \multirow{2}{*}{ (DIN 4074-5 2008, German) } & D40 \\
\hline & & & LS10 or higher & & D35 \\
\hline & & \multirow[t]{4}{*}{ France* } & H1 & \multirow{4}{*}{ (NF B 52-001 2011, French) } & $\mathrm{D} 40$ \\
\hline & & & $\mathrm{H} 2$ & & D35 \\
\hline & & & $\mathrm{H} 3$ & & D24 \\
\hline & & & $\mathrm{H} 4$ & & D18 \\
\hline Maple & $\begin{array}{l}\text { Acer } \\
\text { pseudoplatanus }\end{array}$ & Germany & LS10 or higher & (DIN 4074-5 2008, German) & D30 \\
\hline \multirow[t]{2}{*}{ Oak } & $\begin{array}{l}\text { Quercus } \\
\text { petraea }\end{array}$ & \multirow[t]{2}{*}{ Germany } & LS10 & \multirow[t]{2}{*}{ (DIN 4074-5 2008, German) } & \multirow[t]{2}{*}{ D30 } \\
\hline & Quercus robur & & & & \\
\hline \multirow[t]{4}{*}{ Poplar } & \multirow[t]{2}{*}{ Populus spp. } & \multirow[t]{2}{*}{ France** } & ST-II & \multirow{2}{*}{ (NF B 52-001 2011, French) } & $\mathrm{C} 24$ \\
\hline & & & ST-III & & $\mathrm{C} 18$ \\
\hline & \multirow[t]{2}{*}{ Populus nigra } & \multirow[t]{2}{*}{ Germany } & LS13 & \multirow{2}{*}{ (DIN 4074-5 2008, German) } & $\mathrm{C} 27$ \\
\hline & & & LS10 or higher & & $\mathrm{C} 22$ \\
\hline \multirow[t]{3}{*}{$\begin{array}{l}\text { Sweet } \\
\text { chestnut }\end{array}$} & \multirow{3}{*}{$\begin{array}{l}\text { Castanea } \\
\text { sativa }\end{array}$} & Italy & $\mathrm{S}$ & (UNI 11035-1/-2 2010, Italian) & D24 \\
\hline & & \multirow[t]{2}{*}{ France $* * *$} & ST-II & \multirow{2}{*}{ (NF B 52-001 2011, French) } & $\mathrm{C} 24$ \\
\hline & & & ST-III & & $\mathrm{C} 18$ \\
\hline
\end{tabular}

* CEN TC124/WG2/TG1 APPROVED GRADING REPORT No AGR/6/FR/119 from September 2017 (TG1 2017a).

** The assignments only apply to certain poplar clones (EN 1912 2013).

*** CEN TC124/WG2/TG1 APPROVED GRADING REPORT No AGR/7/FR/79 from September 2017 (TG1 2017b).

In Germany, hardwoods are visually strength graded after DIN 4074-5 (2008). Accordingly, in Europe the following German hardwood species can be used as construction timber, after they have been strength graded visually according to DIN 4074-5 (2008):

- Ash

- Beech

- Maple

- Oak

- Poplar 
For these species, the planner can use the data set of characteristic values provided by EN 338 (2016). Other European hardwoods like sweet chestnut from Italy and poplar from France are also listed in EN 1912 (2013). For these species, other national visual strength grading standards have to be applied, though. For Italian sweet chestnut the Italian standard is used, for French poplar the French standard.

The structural timber (solid wood) sorting to strength classes assignments of EN 1912 are optimized for structural timber carrying edge bending loads (Glos and Torno 2008). It is also possible to optimize visual or machine strength grading for a special use (EN 14081-1 2016). For a use as top or bottom plate in house framing, for example, the sorting can be optimized after perpendicular to grain compression strength. For softwood, the present EN 338 (2016) already gives CT (i.e. conifer tension) classes, for sorting that is optimized for parallel to grain tension loading (for use in glulam). This procedure can result in a considerable yield raise, since safety deductions are avoided.

Also, so-called "CEN TC124/WG2/TG1 APPROVED GRADING REPORTs" allow for a species from a defined origin to be used as structural timber. At present such grading reports exist for the European hardwoods French beech and French sweet chestnut (Table 3). These hardwoods are also visually graded. To the knowledge of the author, machine strength grading settings, which are defined in a so-called ITT-report, only exist for sweet chestnut at present. The release of these reports is not obligatory. Thus, reports for other European hardwoods might exist, but are kept under lock and key.

In Europe none of the above mentioned native hardwood species are used intensively as load bearing structures, e.g. as joists, rafters, studs or plates. Some European carpentries (e.g. Tajak Holzbau, DLK Melle, etc.) still construct traditional framework houses out of oak solid wood or use the product for the restoration of old structures. Here, only minor hardwood volumes are consumed. Exact production or consumption volumes are not known.

\subsubsection{Glulam}

Hardwood glulam can at present not be produced after the harmonized EN 14080 (2013), like softwood glulam. To produce hardwood equivalents, national technical approvals (in Germany "abZ" for "Allgemeine bauaufsichtliche Zulassung") as well as European Technical Assessments (ETAs) on the basis of EADs (European Assessment Documents) are alternative routes for manufacturers. Table 4 lists the hardwood glulam products, for which such documents respectively approvals exist at the moment. 
Table 4: European hardwood glulam products with a valid technical building approval (Aicher 2016a, adapted).

\begin{tabular}{llll}
\hline Species & Origin & Approval & Holder of Approval \\
\hline Beech & Germany & Z-9.1-679 (DIBt 2014a) & $\begin{array}{l}\text { Studiengemeinschaft } \\
\text { Germany }\end{array}$ \\
& France & ETA 13/0642 (OiB 2013c) & Elaborados y Fabricados Gamiz S.A., Spain \\
Oak & Germany \& & Z-9.1-821 (DIBt 2013b) & Holz Schiller GmbH, Germany \\
& Czech Republic & & \\
Sweet Chestnut & Spain & ETA 13/0646 (OiB 2013b) & SIEROLAM S.A., Spain \\
Beech LVL ('BauBuche') & Germany & Z-9.1-837 (DIBt 2013a) & $\begin{array}{l}\text { Pollmeier Furnierwerkstoffe } \\
\text { Germany }\end{array}$ \\
& & ETA 14/0354 (OiB 2015) & GmbH, \\
\hline
\end{tabular}

Except of beech LVL glulam ('BauBuche'), all products listed in Table 4 are classical glulams comprised of boards/lamellas. For the beech LVL glulam, laminated veneer lumber (LVL) panels are ripped and glued to a glulam equivalent with superior mechanical properties. The company 'Hasslacher Norica Timber' (Austria) is at present working towards ETAs (European Technical Assessments) for both birch glulam and birch CLT (cross-laminated timber). The origin of the logs is in both cases Russia (Jeitler 2016). The company 'NOKA' (Germany) is at present preparing a DoP (Declaration of Performance) for curved oak glulam of German origin (Norrenbrock 2017).

\subsubsection{Other products}

The production of finger jointed solid hardwood (construction timber) is not possible under the current harmonized European system. National or European approvals do not exist either. Consequently, no volumes are available on the market.

The producer of glulam made from beech LVL ('Pollmeier Furnierwerkstoffe GmbH', Germany) is also the holder of the German technical approval Z-9.1-838 (DIBt 2016) - beech LVL panels (without and with transverse veneer layers) for structural applications. This product is also the base product for beech LVL glulam ('BauBuche').

The harmonized European standards EN 636 (2015) and EN 13986 (2015) allow the production of plywood for structural applications from hardwoods. Approvals for such plywood panels are held by the companies 'Hess \& Co. AG' (Switzerland) for beech plywood (DIBt 2013c) and by 'Metsäliitto Cooperative Metsä Wood' (Finland) for birch plywood (DIBt 2014b). According to Aicher (2014) 'Welde Bulgaria AD' (Bulgaria) drew up a DoP (Declaration of Performance) for poplar plywood. All these products are available on the market and can be used, for example, as paneling in house framing. The latter is - covered with special water-repelling resin paper-mostly used as shuttering (for building reinforced concrete forms) in the building industry.

For the same industry, the company 'Doka Group' (Austria) holds an ETA (European Technical Assessment) for the highly specialized timber formwork beam 'I tec 20'. This I-joist is comprised of the above-mentioned 'Welde Bulgaria AD' poplar plywood web (Aicher 2016b) and flanges consisting of glued together birch (Baltic origin) and spruce lamellas. This product, though, is at present not produced (Wenighofer 2016). 
The 'Consorzio Servizi Legno Sughero' (Italy) holds the ETA-12/0540 (OiB 2013a), which allows it to produce and market square-edged sweet chestnut logs with wane as durable strength graded structural timber.

Aicher (2014, 2016a, 2016b) as well as Torno et al. (2017) summarize the available hardwood products and the current standard situation concerning the load bearing application of hardwoods in Europe.

\subsubsection{Research activities}

All of the above listed products have been subject to intensive testing. As consequence, they can be produced according to a harmonized European standard or a national or European technical building approval. Company-driven studies are product-oriented. Some of these research activities have been carried out together with independent research institutions. These independent research institutions also perform autonomous research aiming for building application of hardwoods. In the last 15 years, these research activities became abundant. The document Steiger et al. (2014) summarizes the research conducted on beech glulam until the year 2014. Wehrmann and Torno (2015) list the research conducted mainly on sawn hardwood products (solid wood, finger jointed solid wood, glulam and CLT). It becomes clear that in most cases these past research activities were not coordinated between the different institutions. It is also obvious that the scientific problems, which are to be addressed along the production chain, are numerous.

\subsection{Strength grading of hardwood}

Strength grading of boards is a key part of the production chain of glulam but also CLT, structural timber and finger jointed structural timber. Glos and Lederer (2000) proposed visual grading rules, which led to the establishment of the first German visual strength grading standard for European hardwoods DIN 4074-5 in the year 2003. Their work and the work of Glos and Näher (2005) led to the integration of the German hardwood species oak and beech into EN 1912 (2013). The species poplar, ash and maple followed on the basis of the work of Glos and Torno (2008). French poplar (Populus spp.) and Italian sweet chestnut (Castanea sativa) are now also part of the EN 1912 (2013) list of hardwood species. Furthermore, it is possible to strength grade French beech and French sweet chestnut visually in accordance with the French visual strength grading standard NF B 52-001-1 (2011) due to so-called APPROVED GRADING REPORTs. Machine strength grading for European hardwoods is possible for sweet chestnut from Italy based on an ITT report for a 'Microtec' (Italy) machine. This report is not publicly available. Other reports for hardwoods, which are kept under lock and key, might also exist.

\subsubsection{Sorting timber}

Natural products are often characterized by a limited possibility to influence their characteristics during the production process. That is why the final products have to be sorted in order to ensure certain desired characteristics. When sorting timber, it is important to consider the end use of the timber product. Augustin (2004) identifies three different end uses, after which sawn timber can be sorted:
(A) Load bearing capacity (e.g. strength grading for construction use),
(B) Appearance (e.g. color for kitchen cabinet fronts),
(C) Suitability for special applications (e.g. dimensional stability for flooring). 
Timber with a defined load bearing capacity (A) previously underwent so-called strength grading. The harmonized European standard EN 14081-1 (2016) is the basis for this strength grading. An example for sorting after appearance (B) are the sorting rules of the US-American National Hardwood Lumber Association (2007). These rules are applied (adapted) by the biggest German hardwood processor 'Pollmeier Massivholz GmbH \& Co. KG' for sorting beech timber for various applications. A European standard for sorting hardwood after appearance is the EN 975-1 (2011). A special application (C) is the use of softwood for profiled boards, for which the EN 14519 (2006) gives specifications. The characteristics that need to be determined, can in all three cases (A, B, C) be the same (one or more). It is the goal of each sorting process to divide an original set of elements (e.g. boards) into sub-sets, which are characterized by a homogenization of one or more defined characteristics.

\subsubsection{Direct and indirect sorting}

Timber can be subject to direct or indirect sorting. In direct sorting the measured value is also the target value. An example for direct sorting is the sorting of beech boards for kitchen cabinet fronts into boards with and without red-heart. The tensile strength of a glulam board can only be determined in a destructive way. In order to gain information about the tensile strength of a glulam board without destructively testing it, a correlation model is applied. Wood characteristics that can be determined in a non-destructive way ("NDT" for "non-destructive testing") and that also have an influence on the tensile strength are numerous $\left(\mathrm{MOE}_{\mathrm{dyn}}, \mathrm{MOE}_{\text {stat }}\right.$, knot parameters, density, year ring width, etc.). They are called indicating properties or IPs (Hanhijärvi and Ranta-Maunus 2008; Ridley-Ellis et al. 2016). By using one of these parameters (model value) in a rather simple linear model or by combining more than one parameter to a complex model, the target value (in this case tensile strength) is described. The correlation of the model and the target value can be evaluated through statistical correlation analysis and is described by the correlation coefficient $R$ or the coefficient of determination $R^{2}$ (Sachs 1982). Typically, they are described with the $\mathrm{R}^{2}$ value, which can range for the description of the tensile strength of spruce wood from 0.30 to 0.78 - depending on the model (Augustin 2004). The higher the $\mathrm{R}^{2}$ value is, the better the indirect sorting works. Augustin (2004) explains the theory of sorting timber in depth and gives illustrative examples.

\subsubsection{Strength grading}

The goal of strength grading is to divide an original set of boards through sorting into sub-sets. The generated sub-sets are characterized by differing frequency distributions of single board strength values. Figure 4 visualizes this process for the tensile strength $\left(f_{t, 0}\right)$ of spruce boards. The original set of values is divided into three sub-sets $(a, b, c)$ with a clear gradation of characteristic strength values $\left(f_{t, 0, k}\right)$. This leads to a better use of the material potential and as consequence in a higher value yield. 


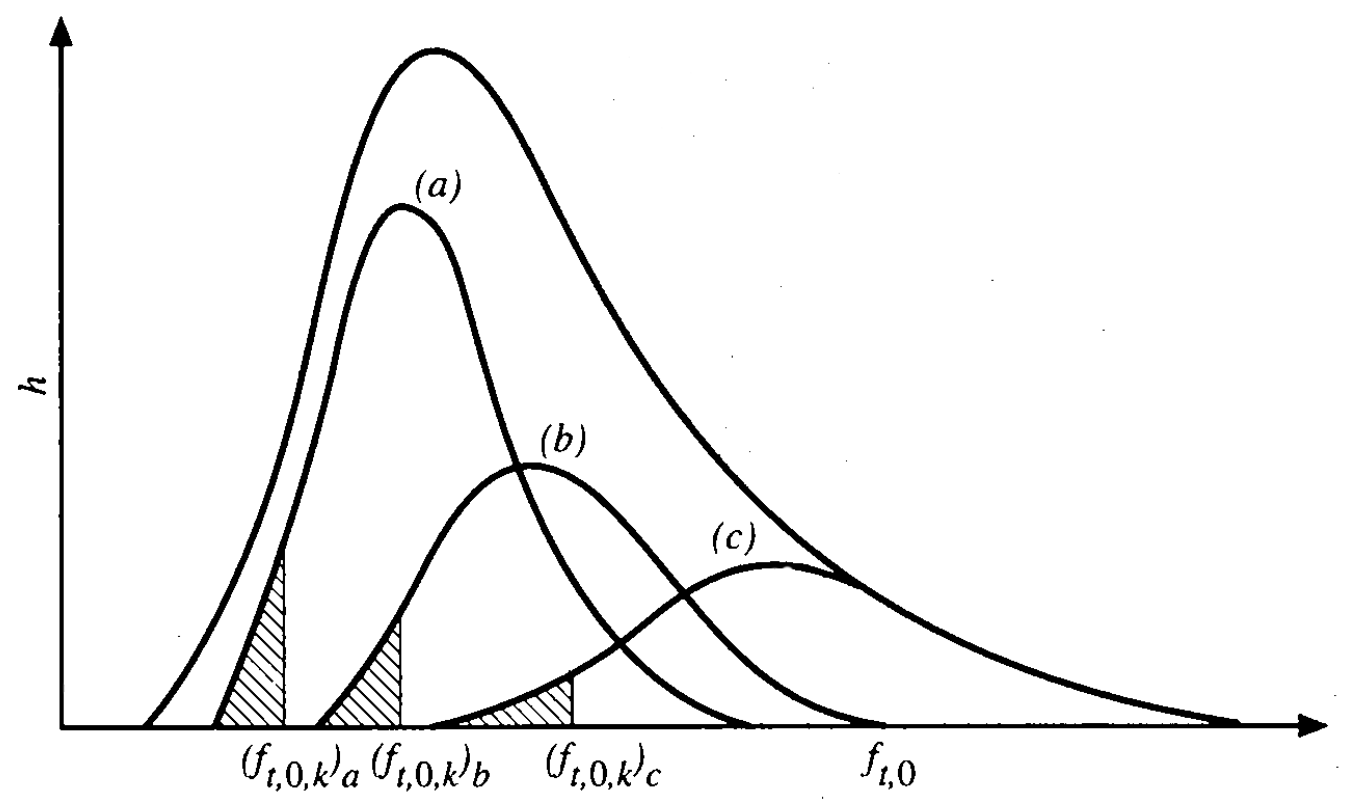

Figure 4: Frequency distributions of original set of elements (overarching line) devided into three subsets $(a, b, c)$ with graduated characteristic tensile strength values (Glos 1995).

For each wood-based product for construction purposes, a product standard exists, which defines the product, its production and its labeling (Figure 1). These standards can be (in most cases harmonized) European standards (EN), national standards (e.g. DIN) and national (e.g. abZ) or European technical approvals (ETA). The Eurocode 5 (EN 1995-1-1 2010) gives planers and engineers instructions, how to design a building with timber. The strength, stiffness and density values for calculating the construction are to be retrieved from EN 338 (2016) for construction timber. For softwood glulam beams, the calculation values are provided by the EN 14080 (2013). For the market available hardwood glulam, the values are part of the national or European technical approvals (abZ or ETA). Cross laminated timber (CLT, only softwood) is also produced after technical approvals (abZ or ETA), where the calculation values are also found (Studiengemeinschaft Holzleimbau e.V. and Überwachungsgemeinschaft Konstruktionsvollholz e.V. 2017).

Each strength class (from EN 14080 2013; EN 3382016 or technical approvals) has a set of characteristic values. In a production facility, solid wood respectively each lamella for glulam or CLT has to be strength graded in order to be assigned to a strength class. This strength grading can happen visually, with a machine and via a combination of both. EN 14081-1 (2016) gives requirements a national visual strength grading standard has to fulfill. These national standards give explicit grading rules. EN 14081-1 (2016) also gives requirements for machine strength grading and refers to EN 14081-2 (2013) and EN 14081-3 (2012) for further specifications for machine strength grading. Regardless of the strength grading technique, the tested "sample" (a sorted batch) has to show characteristic (bending or tensile) strength and stiffness (plus density) values that are equal or higher the values of the strength class. This can be proved by testing the wood destructively in compliance with EN 408 (2012) and EN 384 (2016). How exactly this has to be carried out by a producer, EN 14081-1 (2016) specifies. It is stated that initial testing of the sorting scheme has to be carried out and that a constant in-house production control has to be installed. Ridley-Ellis et al. (2016) state that strength grading in Europe is a rather confusing issue, which often leads to misunderstanding, even 
between structural engineers and timber researchers. The aforementioned publication as well as Augustin (2004) and Stapel (2014) give comprehensive explanations of the topic.

EN 14081-1 (2016) is the harmonized European standard, which sets the basis for strength grading in Europe. It defines requirements, national visual strength grading standards have to comply with and mentions EN 1912 (2013), in which national visual strength grading assortments (grade and species) are already assigned to EN 338 (2016) strength classes (due to former extensive testing or many years of experience in use). It also sets rules for machine strength grading and refers to part 2 and 3 of EN $14081(2012 ; 2013)$ for further rules for machine strength grading.

For the efficiency of strength grading, it is important to know about the end use of the graded timber. General construction timber (solid wood or finger jointed solid wood) typically experiences bending stress (as joist or rafter). Thus, its strength grading is based on data from edge bending tests (C- and D-grades of EN 338 2016). The knowledge about that timber is therefore limited to knowledge about bending strength, bending stiffness and density. Values for other properties (e.g. tension strength, etc.) are conservatively estimated. When using a lamella for glulam, its tension properties are more important than its bending properties for the final glulam strength. Hence, its sorting is based on tension testing (T-grades of EN 338 2016). Equivalently, the bending properties are conservatively estimated. It is possible to utilize a tension graded board in an upright position under bending load, but in this way it is not used to its full static potential (Ridley-Ellis et al. 2016).

\subsubsection{Visual strength grading}

In visual strength grading, especially trained personnel assigns each piece of wood to a sorting class based on visual evaluation. In German production sites, for softwood the DIN 4074-1 (2012) is applied and for hardwood the DIN 4074-5 (2008), since these two standards fulfill the requirements set by the aforementioned EN 14081-1 (2016). The sorting criteria (wood characteristics) listed in these two standards are nearly identical. Both standards depict, how the criteria are measured. Table 5 shows the criteria and the threshold values for the three hardwood sorting classes LS7, LS10 and LS13 of DIN 4074-5 (2008) for boards or planks (e.g. for glulam) that are not stressed in an upright position. In addition to this table, in both standards "other characteristics" are mentioned (e.g. mechanical damage, inbark, etc.). LS13 is the highest strength grading class, which allows the least amount of wood characteristics in the boards. If one sorting criterion of a board does not pass the threshold value of the lowest class LS7, this board must be sorted out (reject). 
Table 5: Sorting criteria of Table 3 of DIN $4074-5$ (2008) for hardwood boards and planks (translated).

\begin{tabular}{|c|c|c|c|}
\hline \multirow[t]{2}{*}{ Sorting criteria } & \multicolumn{3}{|c|}{ Sorting classes } \\
\hline & LS7 & LS10 & LS13 \\
\hline \multicolumn{4}{|l|}{ 1. Knots } \\
\hline - $\quad$ Single knot (DEB) & $\leq 1 / 2$ & $\leq 1 / 3$ & $\leq 1 / 5$ \\
\hline - $\quad$ Knot cluster (DAB) & $\leq 2 / 3$ & $\leq 1 / 2$ & $\leq 1 / 3$ \\
\hline$-\quad$ Edge knot ${ }^{a}$ & - & $\leq 2 / 3$ & $\leq 1 / 3$ \\
\hline 2. $\quad$ Slope of grain ${ }^{b}$ & $\leq 16 \%$ & $\leq 12 \%$ & $\leq 7 \%$ \\
\hline 3. Pith & not allowed $^{\mathrm{c}}$ & not allowed & not allowed \\
\hline $\begin{array}{ll}\text { 4. } & \text { Annual ring width }\end{array}$ & - & - & - \\
\hline \multicolumn{4}{|l|}{ 5. Shake } \\
\hline - $\quad$ Shrinkage crack & allowed & allowed & allowed \\
\hline - $\quad$ Frost crack, ring shake & not allowed & not allowed & not allowed \\
\hline 6. Wane & $\leq 1 / 3$ & $\leq 1 / 4$ & $\leq 1 / 8$ \\
\hline \multicolumn{4}{|l|}{ 7. Warp $^{\mathrm{d}}$} \\
\hline - Bow & $\leq 12 \mathrm{~mm}$ & $\leq 8 \mathrm{~mm}$ & $\leq 8 \mathrm{~mm}$ \\
\hline - $\quad$ Twist & $2 \mathrm{~mm} / 25 \mathrm{~mm}$ width & $1 \mathrm{~mm} / 25 \mathrm{~mm}$ width & $1 \mathrm{~mm} / 25 \mathrm{~mm}$ width \\
\hline - $\quad$ Cup & $\leq 1 / 20$ & $\leq 1 / 30$ & $\leq 1 / 50$ \\
\hline \multicolumn{4}{|l|}{ 8. $\quad$ Stains, rot } \\
\hline $\begin{array}{l}\text { - Nailable brown and red } \\
\text { stains and streaks }\end{array}$ & $\leq 3 / 5$ & $\leq 2 / 5$ & $\leq 1 / 5$ \\
\hline - $\quad$ Rot & not allowed & not allowed & not allowed \\
\hline 9. Worm holes & \multicolumn{3}{|c|}{ not allowed } \\
\hline 10. Other characteristics & \multicolumn{3}{|c|}{ are to be taken into account following the other sorting criteria } \\
\hline \multicolumn{4}{|l|}{ a not applicable for glulam boards } \\
\hline \multicolumn{4}{|l|}{${ }^{\mathrm{b}}$ not to be considered for beech } \\
\hline c allowed for oak & & & \\
\hline
\end{tabular}

DIN 4074-1 (2012) provides the same table for softwood strength grading. The majority of the grading is the same. Some details of that table are different, though:

- For hardwoods, the annual ring width is not a sorting criterion, while for softwoods it is.

- The criterion wane is being evaluated stricter in hardwoods.

- For softwood, only specific degrees of compression wood are allowed. For hardwood, tension wood is not part of the list.

- Worm holes are not allowed in hardwood boards, whereas in softwood $2 \mathrm{~mm}$ holes are still allowed.

For some hardwood species, exceptions were introduced (Table 5, footnotes), like the fact that for beech the slope of grain (grain angle) is not to be considered. In contrast, Volkmer et al. (2017) stress the importance 
of the slope of grain for the finger joint strength of beech glulam lamellas. This sorting criterion has to be seen critically, when sorting visually. In fact, a series of authors has articulated serious doubt in the described method to determine the slope of grain visually (Glos and Lederer 2000; Schickhofer and Augustin 2001; Augustin 2004; Glos and Torno 2008; Torno and Van de Kuilen 2010). For softwood, a machine system for determining slope of grain has been developed and proven - the tracheid effect. This system is at present not applicable for hardwoods (Van de Kuilen and Torno 2014). Paper d of this dissertation shows that available machine systems are able to determine the slope of grain for most of the studied hardwood species. As this brief digression already shows, the characteristics (soring criteria) of the visual sorting can also be part of a machine sorting system (e.g. knot size, slope of grain, pith, etc.).

Intensive research in the past led to the assignment of national sorting classes for strength grading to the strength classes of the EN 338 (2016). This means that it has been proven by testing big data sets that the characteristic strength, stiffness and density values of the graded wood set (certain species from certain origins) are at least as high as the values stated by EN 338 (2016). The report of such research has to be submitted to the European Committee for Standardization (CEN) committee TC124/WG2/TG1 for examination. After successful examination, the assignments can be found in the European standard EN 1912 (2013) or an approved grading report (like TG1 2017a). Table 6 shows the assignments for the most used species spruce (in construction) and for the hardwood species of German origin.

Table 6: Sorting class to (edge bending) strength class assignments of EN 1912 (2013) for construction timber of German origin.

\begin{tabular}{|c|c|c|c|c|c|c|c|}
\hline \multirow{3}{*}{$\begin{array}{l}\text { Softwood } \\
\text { Hardwood }\end{array}$} & \multicolumn{7}{|c|}{ Strength classes (EN 338) } \\
\hline & \multirow[t]{2}{*}{ C18 } & \multirow[t]{2}{*}{$\mathrm{C} 22$} & \multirow[t]{2}{*}{$\mathrm{C} 24$} & \multirow[t]{2}{*}{$\mathrm{C} 27$} & $\mathrm{C} 30$ & $\mathrm{C} 35$ & $\mathrm{C} 40$ \\
\hline & & & & & D30 & D35 & D40 \\
\hline & \multicolumn{7}{|c|}{ Sorting classes } \\
\hline & \multicolumn{7}{|c|}{ (according to DIN 4074-1 and DIN 4074-5) } \\
\hline Spruce & S7 & & S10 & & S13 & & \\
\hline Poplar & & $\geq \operatorname{LS} 10$ & & LS13 & & & \\
\hline Beech & & & & & & $\geq \mathrm{LS} 10$ & LS13 \\
\hline Oak & & & & & LS10 & & \\
\hline Ash & & & & & & & $\geq \mathrm{LS} 10$ \\
\hline Maple & & & & & $\geq \mathrm{LS} 10$ & & \\
\hline
\end{tabular}

The poplar (Populus nigra of German origin) characteristics profile is similar to that of softwoods. Therefore, it is sorted according to the hardwood sorting rules (DIN 4074-5 2008), but is assigned to the softwood strength classes C22 and C27.

\subsubsection{Machine strength grading}

Strength grading machines, that perform a static bending test, were first introduced in the 1960s in the USA (Bendtsen and Youngs 1981; Galligan and McDonald 2000). Since then machine grading has evolved. Especially since computers were able to process big sets of data very fast, the way was free for the 
incorporation of new methods into strength grading. Today's sorting machines make use of modern CCD-camera systems to capture visual sorting criteria ("automated visual sorting"). They also utilize X-ray scanning, natural frequency and ultrasonic transit time measurements $\left(\mathrm{MOE}_{\mathrm{dyn}}\right)$. Like mentioned above, the tracheid effect is being applied to determine the slope of grain. Some machines on the market still bend the boards statically to determine the static $\mathrm{MOE}\left(\mathrm{MOE}_{\text {stat }}\right)$. Boards are weighted with scales to determine their density and moisture contents are being determined via electrical field strength measurements (Bacher 2008; Hanhijärvi and Ranta-Maunus 2008; Bengtsson 2010; Krzosek and Bacher 2011; Stapel 2014). New developments also include microwave measurements (Denzler and Weidenhiller 2015). Augustin (2004) summarizes the technologies applicable for machine sorting of sawn timber.

All technologies utilized to predict timber properties (i.e. strength, stiffness and density) have in common that they are non-destructive ("NDT" for "non-destructive testing"). So-called IPs (indicating properties) are used to forecast the grade determining properties. Thus, strength grading is in most cases an example of indirect sorting. As described above, an IP can be made up of only one or a combination of non-destructive testing (NDT) parameters (Hanhijärvi and Ranta-Maunus 2008; EN 14081-2 2013; Ridley-Ellis et al. 2016).

EN 14081- all parts $(2012 ; 2013 ; 2016)$ generally distinguish between two different machine strength grading systems that both can make use of the above-mentioned IPs:

(A) Output control, which means that parts of the sorted timber have to be tested and consequently the machine settings are adjusted in the production facility. This happens periodically.

(B) Machine control systems rely on default settings of sorting machines, which are the result of intensive destructive testing.

Both systems have their intrinsic advantages, which are described by EN 14081-2 (2013). They have in common that a so-called "visual override" is obligatory for detecting strength reducing defects, which cannot be detected by the machine (Bacher 2008; EN 14081-1 2016; Ridley-Ellis et al. 2016). Trained personnel or a machine system (e.g. CCD-cameras) can carry out this "visual override".

It is also possible to combine visual and machine strength grading. The sorting of beech boards according to the German technical approval for beech glulam (DIBt 2014a) is an example of such a combination. Here the boards are sorted according to DIN 4074-5 (2008) and additionally MOE $_{\text {dyn }}$ (dynamic Modulus of Elasticity) threshold values have to be met. The $\mathrm{MOE}_{\mathrm{dyn}}$ is being measured by determining the natural frequency from longitudinal oscillation and by determining the density. Machines carry out both measurements.

\subsubsection{Mechanical properties}

Compared to softwood, the different European hardwood species show stronger differences in their characteristic's profiles (Welling 2012). The mechanical properties of structural timber depend on a series of factors, which are summarized by Glos (1978). Silvicultural practice as well as soil and climate influence wood characteristics. Tree intrinsic factors like genetics, position in tree, age or life story (i.e. top rupture etc.) also influence mechanical properties. Amongst others, these factors lead to a certain structure of the wood tissue, which can be described on a microscopic or a macroscopic level. By strength grading, the wood is sorted on the macroscopic level. As described above, sorting depends greatly on the end use of the product. The semi-probabilistic safety concept behind the harmonized European design standard Eurocode 5 (EN 1995-1-1 2010) reduces characteristic strength and stiffness of EN 338 (2016) by applying a series of deduction factors. EN 338 (2016) characteristic values are attained via mechanical testing, but 
here also deduction factors reflecting statistical uncertainties already reduced the values. To the knowledge of the author, only one European research project so far evaluated all mechanical properties listed in Table 1 of EN 338 for hardwoods. Hunger and Van de Kuilen (2015) tested beech and ash construction timber and give suggestions for value changes of EN 338 (2010) design values. Other projects only cover single elements of the strength profile depending on the end use. For beech, oak, ash, maple and poplar, data derived from four-point edge bending tests is available (Glos and Lederer 2000; Glos and Näher 2005; Glos and Torno 2008). For beech, oak, ash and birch tension testing of lamellas for an application in glulam supplied useful data (Frühwald et al. 2003; Frühwald and Schickhofer 2005; Jeitler and Augustin 2016; and others). Such research leads to a species-specific optimization of design values and aims for a raised yield. For example, perpendicular to grain compression strength design values for medium dense European hardwoods were lowered in the latest EN 338 (2016) version compared to EN 338 (2010). 


\section{Objectives}

As explained above, in central Europe hardwoods are hardly used in load bearing applications. It is the goal of this dissertation to (A) identify the underlying reasons and to (B) contribute to knowledge increase to work towards a greater integration of hardwoods into the building sector.

(A) The identification of the underlying reasons for the marginal use of hardwoods in building construction was realized within the last years with qualitative methods:

a. Literature study

b. Personal interviews (forestry officials, sawmill owners, construction timber producers, machine suppliers, scientists, politicians, etc.)

c. Conference attendance (presenter and listener)

(B) The scientific papers listed in this dissertation aim to contribute to an overall increase in knowledge about selected aspects along the production and utilization chain of hardwood construction timber (and glulam). The focus of these studies is set on strength grading and the related strength characteristics (amongst others) of European hardwoods, for which - compared to softwoods - the knowledge is scarce. The following paragraphs define the objectives and summarize the background of each scientific paper, which evolved in the course of this dissertation. Complete papers are annexed.

\section{a. Visual and machine strength grading characteristics of six European hardwoods}

This paper aims to characterize boards (lamellas) of six native hardwood species (ash, beech, birch, maple, oak, lime) originating from low to medium quality and low to medium dimension logs via visual (according to DIN 4074-5 2008) and machine ( $\mathrm{MOE}_{\mathrm{dyn}}$ and density) strength grading. The six hardwood species were selected due to their availability in northern Germany and their promising wood characteristics in relation to construction use. By analyzing the sourced material, the following questions were to be answered:

1. When using market available, low to medium quality sawn hardwood timber assortments, what is the quality yield when graded visually according to DIN 4074-5 (2008)?

2. Are all visual sorting parameters named by the DIN 4074-5 (2008) attainable for the selected hardwoods?

3. Do the different hardwood species show typical characteristics respectively characteristics distributions?

\section{b. Analysis of economic feasibility of ash and maple lamella production for glued laminated timber}

This paper links the aspects strength grading and final volume and value (grade) yield. The use of small diameter logs from thinnings as poor-quality resource is in focus of this yield analysis. The yield analysis from $\log$ sections to planed and graded glulam lamellas is performed with state of the art processing 
technology. Moreover, the achieved yields are linked to the mechanical properties relevant for glulam lamellas and measured for the investigated samples. Doing so, the economic feasibility of lamella production out of small diameter logs of the rare hardwood species maple and ash is estimated.

\section{c. Visual and machine strength grading of European ash and maple for glulam application}

Medium dense hardwoods show higher tensile strength values compared to softwoods. These advantages cannot be utilized effectively as the grading of hardwoods is less developed. The aim of the study is to analyze the optimization potential of grading European ash and maple grown in Central Europe and develop optimized grading schemes. Therefore, for 869 hardwood boards, the visual grading characteristics were determined and the dynamic Modulus of Elasticity $\left(\mathrm{MOE}_{\mathrm{dyn}}\right)$ and $\mathrm{x}$-ray attenuation were measured using an industrial scanner. Afterwards, the specimens were tested in tension in accordance with EN 408 (2010).

\section{d. Comparison of three systems for automatic grain angle determination on European hardwood for construction use}

Automatic grain angle determination on construction timber by means of the tracheid effect is a widely used tool to inspect softwood construction timber in the industry. Together with parameters like dynamic Modulus of Elasticity $\left(\mathrm{MOE}_{\mathrm{dyn}}\right)$, density and others, strength grading is carried out (Olsson et al. 2013). So far, for hardwoods such grading systems are not in use. This is on the one hand due to the comparably low use of hardwood in construction and consequently low research efforts in this field. On the other hand, literature reports a limited functionality of the tracheid effect on hardwoods. Therefore, it is the goal of this paper to evaluate the laser tracheid effect used in the industry for softwood concerning its suitability for grain angle determination on European hardwood timber. As alternative systems, the electrical field strength measurement and microwave scanning are tested. The machine measurements are compared to visually determined grain angles on physically split specimens (reference angles).

\section{e. Effect of size and geometry on strength values and MOE of selected hardwood species}

The strength and stiffness properties of a wood member depend on its size and quality (occurrence of defects) - so do the strength and stiffness values of test specimens. This paper aims to provide strength and stiffness values derived from defect-free specimens of different sizes and examines the so-called size effect for the selected hardwoods maple, birch, beech, ash, oak and lime. Compression, bending and tensile tests (all parallel to grain) were carried out. The six hardwood species were selected due to their availability in northern Germany and their promising wood characteristics in relation to construction use.

\section{f. Critical discussion of perpendicular to grain tension testing of structural timber - case study on the European hardwoods ash, beech and maple}

Independent from the sorting class, EN 338 (2016) assigns only one characteristic value for perpendicular to grain tension strength to hardwood structural timber $-0.6 \mathrm{~N} / \mathrm{mm}^{2}$. This value is set very low and therefore prevents the calculating engineer to make use of the strength advantage of single hardwood species compared to softwood. This is mainly due to the limited data available on the characteristics strength and stiffness perpendicular to grain as well as knowledge about the dependency of these characteristics from 
moisture changes and other influencing factors. This paper contributes to the overall goal of supplying data for an increased use of hardwood in construction. It provides perpendicular to grain tension strength and stiffness values separated after species. As research material the three European hardwood species maple, ash and beech were chosen.

g. Review of EN 338 characteristic (perpendicular to grain compression) strength and stiffness as well as density values for European beech, ash and maple wood [Original title: Überprüfung der in DIN EN 338 angegeben (Querdruck-)Festigkeits- und Steifigkeitseigenschaften sowie Rohdichten für Buchen-, Eschen- und Ahornholz]

This conference paper summarizes the current and former situation concerning characteristic strength, stiffness and density calculation values of hardwood construction timber. As example, perpendicular to grain compression strength testing of construction timber has been performed in accordance with EN 408 (2012). The test set-up as well as the results are discussed critically and are put in relation to design values (EN 338 2010, 2016). 


\section{Synopsis}

\subsection{Hardwoods in construction - challenges along the production and utilization chain (A)}

Figure 5 lists the research issues to be addressed, when developing or optimizing the production chain of hardwood glulam. For other products, which are produced on the bases of sawn wood, the production chains are similar. Only single elements might be different or do not occur.

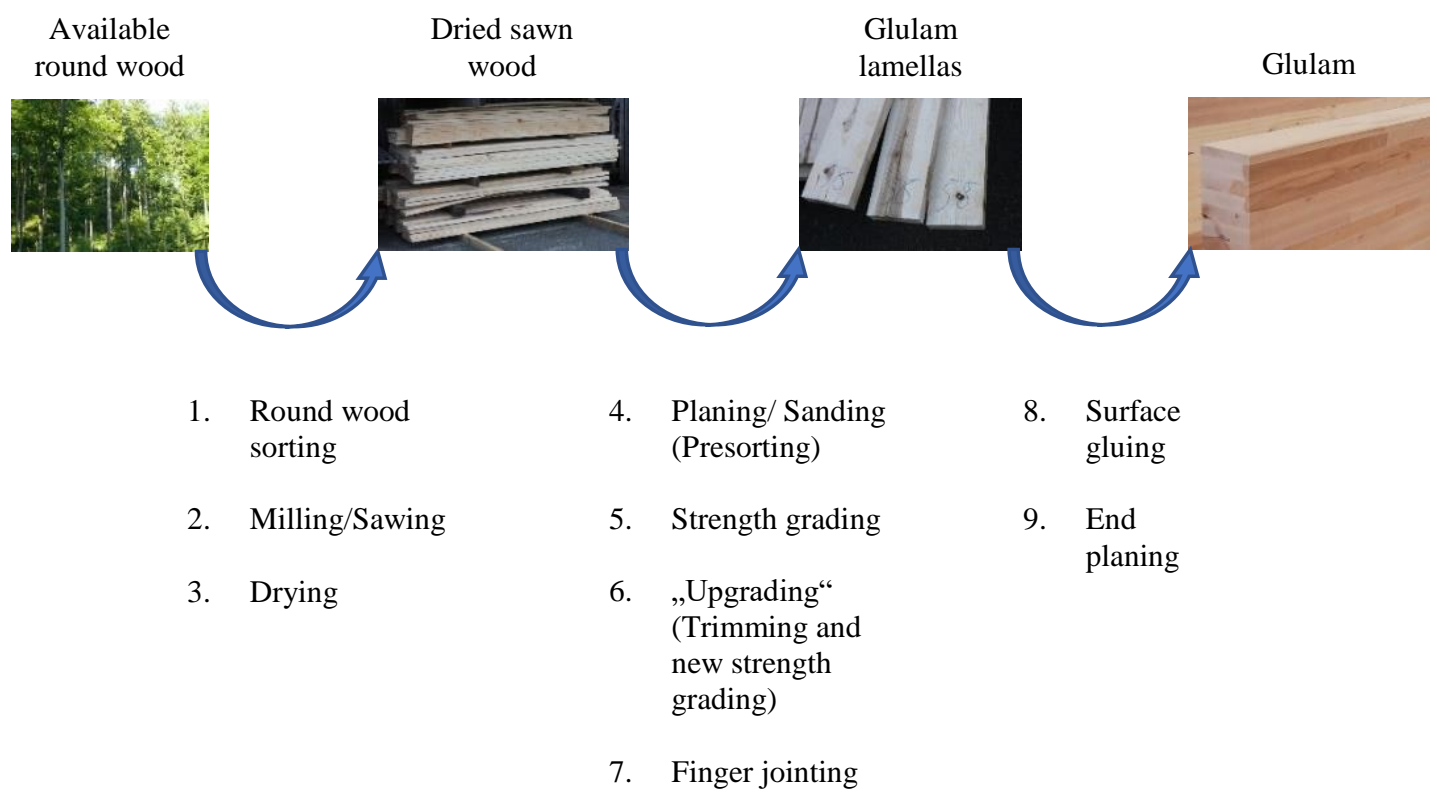

Figure 5: Production chain of glulam.

In the course of this dissertation, so-called "bottle-necks" along the production and utilization chain of hardwood building products have been identified to find explanations, why hardwoods are not used in construction. The findings are summarized in Figure 6. 


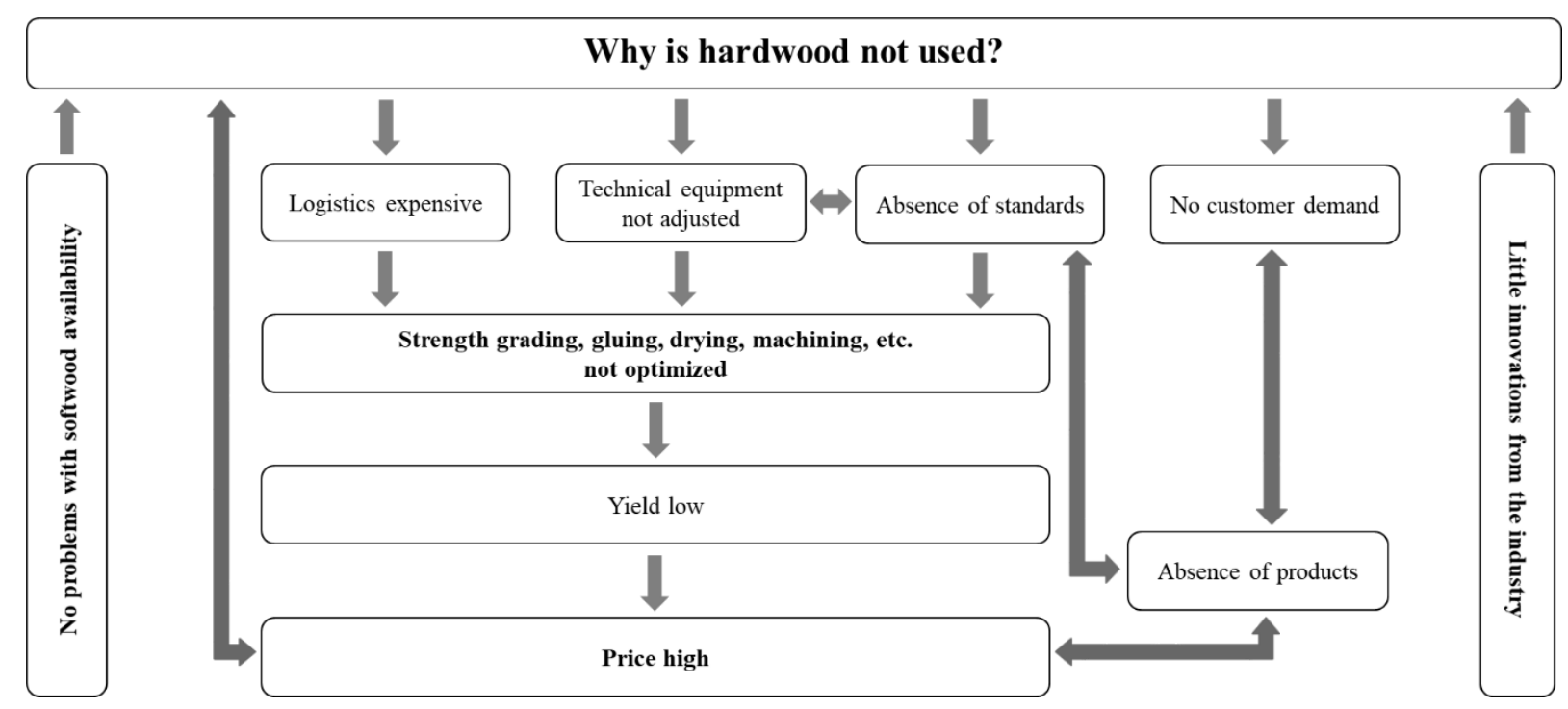

Figure 6: Underlying factors of the low use of hardwoods in construction.

The production chain starts with raw material availability. At the beginning of the $21^{\text {st }}$ century, central European softwood prices were rising, and for the near future the industry predicted a resource shortage of especially spruce round wood. That is why research projects started evaluating the suitability of mainly beech wood as construction material (Frühwald et al. 2003; Blaß et al. 2005; Blaß and Frese 2006; Frese 2006). At the same time an increased use of wood for energy production was favored by political incentives - here mainly beech wood (Seintsch and Weimar 2012). Thus, the price gap between soft- and hardwoods did not rise as predicted. Now, softwood (mainly spruce) raw material supply shortages are compensated by deliveries from eastern European countries, Russia and Scandinavia. Nonetheless, for both hard- and softwoods, the European price development of round wood for sawn wood production is estimated to be positive until 2030 by Kollert and Lebedys (2012). According to their predictions, hardwood prices will rise faster than softwood prices (annual increment $3.3 \%$ compared to $2.9 \%$ ). The prices of the low-quality assortments (for fiber production) will rise even faster (4.6 - 4.8\%). These low quality and low diameter hardwood assortments are the ones, which are at present under discussion for a use in construction. The higher quality assortments are too costly for and application in load bearing structures, where they have to compete with softwood prices. Comparing price estimates for 2030 for high quality softwood round wood (for sawn lumber) with that for low quality hardwood round wood (for fiber production), the price difference is marginal (softwood: $82 € / \mathrm{m}^{3}$, hardwood $79 € / \mathrm{m}^{3}$ ). These figures raise doubts about a wide spread substitution of softwoods by hardwoods in load bearing structures - an aspiration of many national and Europe-wide political and scientific initiatives. Regardless of the price, the low-quality assortments of rare hardwood species (not oak or beech) like ash, maple, birch, lime, etc. do normally not find their way to a sawmill. Although the ALH and ALN species (Table 2) do mostly not occur in pure stands, German forestry officials report local abundance of them. Due to missing assortments for these species or a lack of communication between forest owners, these trees either remain in stands or are sold as industrial round wood or energy wood together with other species. As described in the introduction, at least for Germany all WEHAM scenarios predict a rise in hardwood stocks in the next 35 years - especially in the ALH and ALN species (Federal Ministry of Food and Agriculture 2016). Therefore, it will be a major task of forest politics to develop harvesting and supply strategies for these wood species. 
While softwood sawmills are supplied with their raw material all year round, hardwood sawmills do mostly not get their raw material in the summer season, what makes logistics more difficult. Sawing of hardwoods is due to the mostly higher density slower and therefore costlier. Special hardwoods also present other challenges - e.g. ash, which dulls saw blades very fast. In general, machining of hardwoods means a higher machine wear and often has to be performed slower. Due to the often disadvantageous round wood geometry (bowing, ovality, etc.), sawing yield is in most cases lower than in softwood mills (paper b). Most hardwood sawmills do not follow a yield maximization approach but produce in accordance with received sawn wood orders. Here clear final product definitions and the subsequent optimization of the sawing process for each product separately would raise the yield and consequently would reduce the price of the final product. One example of such a positive development presents the grade sawing method for the production of defined final products performed by the 'Pollmeier Massivholz GmbH \& Co. KG' since the early 1990s. Other Central German sawmills have adapted this method lately (Abalon Hardwood Hessen GmbH, Georg Fehrensen $\mathrm{GmbH}$ ), because it produces higher volume yields than cant sawing or live sawing (Torno et al. 2013). Such developments lead to sawn wood price reductions and work towards the application of hardwoods in new products - e.g. construction.

Drying presents a further cost driving factor. Drying rates of hardwoods are in most cases slower than of softwoods - drying times are mostly a multiple. Oak wood is especially difficult to dry. As example, while in a conventional drying kiln $52 \mathrm{~mm}$ spruce boards can be dried to $8 \%$ moisture content in approximately ten days, it takes over 30 days to dry beech boards and over 90 days to dry oak. Here, superheated steam or vacuum drying might be viable alternatives for some species to reduce drying times and thus capital commitment.

As the papers $\mathbf{b}$ and $\mathbf{c}$ stress, strength grading of hardwoods needs to be optimized in order to raise recovery rates. Next to strength grading itself, the strength characteristics of European hardwoods vary greatly between the different species. Also, the ratios between different strength characteristics (bending, tension, compression, parallel and perpendicular to grain), but also between strength and MOE or density are not the same between the different hardwood species. These ratios have to be evaluated to use the wood to its full static potential. Knowledge concerning design specifications is also scarce. For example, the long-term behavior of the different hardwood species under different climate conditions is mostly not known. Only for beech glulam a study from Jiang (2016) proves the high susceptibility of beech glulam to delamination, which has to be considered, when designing a building. Other fields with knowledge gaps are crack propagation, failure modes and displacement rates. The consequence is a design code, which is far from being optimized for the use of hardwoods, which therefore are not used to their full potential respectively material is wasted due to unnecessary over-dimensioning.

Gluing (surface and finger joint) is a key technology in producing high quality finger jointed construction timber, glulam or CLT. The gluing of beech wood for glulam has been studied by a series of authors (Aicher and Reinhardt 2007; Ohnesorge et al. 2010; Schmidt et al. 2010; Jiang 2016) in the last ten years. Still, the gluing of beech lamellas to glulam (in accordance with DIBt 2014a) is very costly due to long assembly times (up to 70 minutes) and comparatively long pressing times of up to 24 hours. Thus, the producer has to provide expensive temporary storage capacities. Other hardwood species are far less researched concerning gluing. Also, some species contain extractives, which make gluing difficult. Knorz et al. $(2014,2015)$, for example, prove that gluing ash for glulam is more challenging than gluing beech wood. 
The above-listed challenges along the production and utilization chain of hardwood construction products are numerous and may lead to the conclusion that hardwoods are not suited for such an application. Their suitability as elements of load bearing structures depends on many technological and economic factors, which can change over time. This means that a special assortment might not be suitable respectively economic as load bearing element in a building structure at present but can be in the future due to changes in the market situation. As example, the company 'Hasslacher Norica Timber' (Austria) is planning to produce birch glulam and CLT. The input birch wood is a co-product of exploiting a spruce wood concession in Russia. Hitherto, the birch wood was left on site. After evaluating the mechanical properties of the material, the company started sawing the birch wood and brought ETAs on the way. Suddenly, also birch wood from areas in north-east Germany, where birch trees are mixed into pine stands, is being discussed as construction wood alternative.

\subsection{Related papers (B)}

In the center of the flowchart of Figure 6 stands the fact that production processes are far from being optimized for hardwoods. The papers of this thesis focus on the "bottle-neck" strength grading and connected strength properties and design implications. They aim to provide useful data to overcome some of the hurdles named in Figure 6. Furthermore, they are aimed to help decision makers evaluate the true potential of single hardwood species or assortments.

\section{a. Visual and machine strength grading characteristics of six European hardwoods}

This paper provides information on the strength grading characteristics of six European hardwood species. Market available dried sawn wood assortments served as research material. Lamellas with a cross section of $100 \times 30 \mathrm{~mm}^{2}$ and lengths up to 3 meters were strength graded visually according to DIN 4074-5 (2008). Additionally, the dynamic Modulus of Elasticity $\left(\mathrm{MOE}_{\mathrm{dyn}}\right)$ and the density were determined.

Yield wise, the investigated samples of the species ash, maple and oak seem best suited for an application in load bearing applications. They show the highest proportion of very good quality boards (LS13), i.e. low number of big knots and pith. Excluding the criterion pith from sorting raises ash and maple yield values even further and also points out birch to be interesting, when it comes to visual grading yield. Beech and lime wood show very big knots. In lime wood, also inbark is abundant, for which sizes are very difficult to determine. Further research needs to evaluate the strength profiles of these species. Especially, the influence of pith on strength and stiffness needs to be evaluated. A use of pith containing boards in the final product would raise final yield values considerably. For the species lime, ash and beech, the suitability for construction use has to be evaluated by further studies via integrating more factors than sorting characteristics. Lime wood shows an unfavorable strength class distribution and is only available locally in small quantities, which makes it not suitable for an application. Ash wood shows a favorable strength class distribution, but it is expected that the ash dieback disease will diminish the species availability heavily. The studied beech wood shows an unfavorable strength class distribution, but the wide-spread availability of beech wood speaks for an application.

In the future, it will be important to evaluate all factors influencing the economic feasibility of the use of the studied hardwood species in load bearing applications. Here, the resource availability plays a very important role. In German forests, beech and oak trees are the most common hardwood (broadleaved) tree 
species (Federal Ministry of Food and Agriculture 2014). Maple, ash, birch and lime trees do mostly not occur in pure stands, but are mixed in. Due to missing assortments for these rare species or a lack of communication between forest owners, these trees either remain in stands or are sold as industrial round wood or energy wood together with other species. Most of these trees do not find their way into sawmills. Their use in construction can only be economically viable, when special forest utilization and logistics solutions can ensure a constant supply. It is advisable to repeat the presented study for these supplied round wood assortments to investigate their suitability as load bearing elements. Another economically feasible option of raw material provision presents the commercialization of co-products - the use of side-products of high quality products production as construction material instead of using them for energy production.

\section{b. Analysis of economic feasibility of ash and maple lamella production for glued laminated timber}

In this study, the volume yields of the production of glulam lamellas from low quality and low dimension ash and maple log sections are investigated. For this purpose, $15.8 \mathrm{~m}^{3}$ of maple (81 log sections) and $14.3 \mathrm{~m}^{3}$ of ash (79 log sections) were harvested from natural forest stands (mixed beech forests) in central Germany and were turned into dry-dressed lumber (unsorted lamellas) with state of the art technologies. The resulting board volumes amount for only $20.9 \%$ (maple) and $18.2 \%$ (ash) of the original log volumes. The most waste (relative) is produced in the production step "presorting \& planing" (maple: $56 \%$; ash: $60 \%$ ), since here a high percentage of the boards had to be sorted out due to bowing. By trimming these boards to shorter lengths, the waste of this production step could be reduced considerably. In addition, the sawing of the boards produced in both cases around $50 \%$ waste. Nonetheless, with an adjusted sawing technology, this waste can be reduced - e.g. through shorter log sections and optimized machine combinations. It is also advisable to define a minimum input log diameter, since the lower the log diameter is, the lower the volume yield of milling gets. Another approach to a raised final volume and value yield is the diversification of final products. Thus, as an example, glulam lamellas could be produced as low-quality co-product from the production of high quality lumber for furniture production.

Strength grading of lamellas lowers final volume yields even further. When grading the lamellas according to DIN 4074-5 (2008), final volume yields of $12.7 \%$ for maple and $9.1 \%$ for ash are attained. One way of raising the final volume and also value yield, could be the adjustment of the sorting (grading) scheme. For example, by excluding the criterion "pith" from sorting, final yield values of $20.6 \%$ (maple) and $18.2 \%$ (ash) can be achieved. Generally, it is advisable to combine visual and machine sorting to an assortment and species adjusted combined grading, which is optimized after the criteria "desired tensile strength and stiffness" but also "yield". Kovryga et al. (2019, paper c of this dissertation) is attempting this. Resulting total yields, when applying the optimized grading of Kovryga et al. (2019) to this study's lamellas, lie between $17.0 \%$ (ash) and $17.8 \%$ (maple). This yield is considerably lower than that typically obtained for softwood glulam lamellas. Factors like the higher attainable tensile strength, if compared to $30 \mathrm{~N} / \mathrm{mm}^{2}$ possible for softwoods (EN 338 2016), and the appealing appearance of hardwood glulam may make up for the yield disadvantages. In general, the economic feasibility of hardwood glulam is influenced by a series of factors, which have to be analyzed in detail for each final product and production plant separately. 


\section{c. Visual and machine strength grading of European ash and maple for glulam application}

The mechanical properties of graded boards are analysed for visual and combined visual grading methods. Visual grading in accordance with the German visual grading standard DIN 4074-5 (2008) produces characteristic tensile strength of as high as $28 \mathrm{MPa}$ for ash and $30 \mathrm{MPa}$ for maple. By combining the visual and machine strength grading, in a manner Frese and Blaß (2007) did, higher mechanical values can be achieved. For ash, characteristic tensile strength of $62 \mathrm{MPa}$ and for maple $42 \mathrm{MPa}$ are possible.

The obtained mechanical property values for visually graded lamellas are in good agreement with material profiles proposed by Kovryga et al. (2016). These profiles reflect static Modulus of Elasticity (MOE stat $_{\text {) }}$ values better compared to the profiles of the softwood T-Classes for the highest grades of visually and combined graded boards. However, for visually graded timber of lower grades (e.g. LS10) and machine graded timber, the real $\mathrm{MOE}_{\text {stat }}$ seems to be underestimated by the material profiles. For classes with characteristic tensile strengths below $28 \mathrm{MPa}$ the $\mathrm{MOE}_{\text {stat }}$ design value could be increased. For a definite conclusion, values for other wood species should be analyzed.

The parameter "pith" has a low impact on the tensile properties parallel to grain. Rejecting the pith leads only to higher strength classes, when aiming for a characteristic strength of over $54 \mathrm{MPa}$. For classes with lower property values allowing pith increases the yields. The pith in boards used for glulam beams should be allowed, if the desired mechanical properties of the final product glulam remain unaffected. This has to be evaluated, though.

The use of the "edge knot" criterion does not affect the tensile properties of the boards in a meaningful way. Thus, the criterion can be excluded from grading of boards loaded in tension.

Finally, the potential of fully automated grading systems using a combination of $\mathrm{MOE}_{\mathrm{dyn}}$ and X-ray knot detection is studied. With the prediction accuracy $\left(\mathrm{R}^{2}\right)$ of 0.576 for ash and 0.533 for maple, an increase compared to the prediction on the basis of only $\mathrm{MOE}_{\mathrm{dyn}}$ (ash: 0.270; maple: 0.288) can be reported. The machine grading allows grading hardwood timber to higher classes and with higher yields compared to the visual grading. Nevertheless, the performance of machine grading is below the one of the combined grading, as lower yields - especially for grading to classes with superior characteristic property values (> $50 \mathrm{MPa}$ for ash) - are achieved. For grading to DT38/DT34, machine grading appears attractive. Further research is required in order to adapt existing or introduce new technologies to grading of hardwoods.

\section{d. Comparison of three systems for automatic grain angle determination on European hardwood for construction use}

In this study the three systems tracheid effect, microwave measurement and electrical field strength measurement are tesed for their applicability for grain angle determination on hardwood boards. Findings of previous studies, that all three systems are applicable on spruce boards, are confirmed. The reference method splitting, which was used in this study, contains sources of errors - especially in knot areas. Therefore, to evaluate the functionality of a machine measurement system for grain angle determination, mainly the analysis of knotless areas is helpful. A different reference system would raise the informative value of such a study substantially.

No system is found, which shows satisfactory correlations for all six selected hardwood species. Ash shows no correlation at all (with all three systems), while on lime only the tracheid effect shows a high $\mathrm{R}^{2}$ value (0.71). For beech wood, the electrical field strength measurement displays the highest 
correlation (0.66). For birch wood, the correlation is the highest, when using the tracheid effect, although the value is with 0.51 low. It is expected that with rather simple algorithm adjustments, $\mathrm{R}^{2}$ will rise considerably. The system utilizing the tracheid effect is not applicable for oak $\left(R^{2}=0.2\right)$. For oak, the electrical field strength system and the microwave measurement system present true alternatives $\left(R^{2}=0.80\right.$ and 0.73 ). For maple, the system using the tracheid effect and the microwave system are characterized by high coefficients of determination $\left(\mathrm{R}^{2}=0.81\right.$ and 0.88$)$.

In summary, high $\mathrm{R}^{2}$ values ( $\left.>0.60\right)$ reported in this study indicate a high suitability of a system for machine grain angle determination. In contrast, low values do not necessarily mean that the system is not suitable for grain angle determination on this species. A mix of distorting factors (scanning depth, reference method, quality difference in specimens) might lead to a low coefficient of determination.

\section{e. Effect of size and geometry on strength values and MOE of selected hardwood species}

This paper aims to provide data for a review of EN 338 (2010) design values. Furthermore, the size effect and the modes of failure for the different mechanical tests are evaluated. For each test (compression, bending and tensile strength testing parallel to grain) three specimen sizes are compared - Real size, F5 and Standard. The Real size specimens had a cross-section of $100 \times 30 \mathrm{~mm}^{2}$ and were produced in accordance with EN 408 (2012). The F5 specimens had the same aspect ratio as the Real size specimens, but the size was reduced by the factor 5. Additionally, the German standard specimens for testing little, error-free wood specimens were tested (DIN 52185 1976; DIN 52186 1978; DIN 52188 1979). All specimens were error-free.

Regarding the compression strength values, lime achieves the lowest mean values with $38.48 \mathrm{~N} / \mathrm{mm}^{2}$. The highest strength is achieved by Real size birch specimens (mean $61.15 \mathrm{~N} / \mathrm{mm}^{2}$ ). The strength values inside the groups vary only to small extend (standard deviation $1.67-7.25 \mathrm{~N} / \mathrm{mm}^{2}$ ). The standard deviations between the different specimen sizes and species also show small variation. Concerning the size effect, one objective of this study is to evaluate, if the two different lengths (longitudinal direction) of the standard specimens (according to DIN $52185197630 \mathrm{~mm}$ and $60 \mathrm{~mm}$ ) produce different strength results. This is not the case. Comparing all four different sizes, for maple, birch and ash the specimen dimensions do not influence the values. For beech, oak and lime, it is observed that compression strength increases as specimen volume is increased. This is contradictory to Weibull's (1939) theory, which states that with increasing volume the strength decreases. The mode of failure is also affected by the specimen dimensions. In Standard3 and Standard6 specimens the predominating failure mode is the formation of compression wrinkles due to buckling of fibers. Here the lime specimens show a completely different behavior. At the bottom and top of these specimens a bulge is formed. This difference in failure mode is not observed in Real size and F5 specimens. Here buckling of the entire specimen with subsequent formation of strong compression wrinkles is the typical reaction of the specimen to compression stress.

The bending strength values of beech are in most cases superior to that of the other species, whereas lime normally shows the lowest values. In contrast to that the F5 lime specimens have the highest bending strength of all the F5 specimens with a mean value of $111.14 \mathrm{~N} / \mathrm{mm}^{2}$. This is due to a drastically higher raw density in this group (mean $0.72 \mathrm{~g} / \mathrm{cm}^{3}$ ). The standard deviation in most groups is small. Regarding the size effect, for all species the bending strength decreases as the specimen's dimensions are increased. The failure mode of the Standard specimens and the F5 specimens is similar for all species. Like explained in Madsen (1992), typically the upper part of the specimen experiences compression stress in the compression 
zone, to which it reacts quite ductile with wrinkles (i.e. failure), before the lower side under tension fails suddenly with a weak formation of a typical T-break. This presents a mixed mode of failure between tension perpendicular and parallel to grain. The Real size specimens show the same sequence of events. It has to be stated, though, that here clear differences in the failure modes of the different species can be found. While ash and beech show tension failure similar to that of the Standard specimens (weak to pronounced T-break in tension zone), oak and maple fails very brittle, mostly breaking into many little pieces. Lime and birch form very pronounced wrinkles in the compression zone (buckling of fibers), before the tension zone fails quite ductile. The more stress is applied, the littler fiber bundles are torn apart, resulting in many scattered little T-breaks.

Tensile strength values vary greatly. The mean values range from $39.45 \mathrm{~N} / \mathrm{mm}^{2}$ (lime Real size) to $160.50 \mathrm{~N} / \mathrm{mm}^{2}$ (birch Standard). In general, birch and beech Standard specimens attain the highest strength values. In this study, a clear statement of the effect of specimen size on tensile strength is not possible. For that a number of explanations can be listed. First, this is due to the drastic differences in selected specimen shapes (Standard versus Real size and F5). Second, testing set-ups of Real size and F5 specimen testing was not optimal (see failure mode description below). Third, the production of the bone-shaped Standard specimen is very likely to influence the strength values, due to cutting into the fibers, when routering the taper. Concerning the failure mode, the Standard specimens fail very brittle in the center of the specimens. The simple board shape of the F5 and Real size specimens in most cases leads to fracture in the clamping area. Based on these findings, the test set-up for Real size specimens proposed by Blaß et al. (2005) should be employed with special care. Only when a certain knot size (or any other wood debilitating characteristic) is exceeded, interpretation of the results makes sense. Below that characteristic knot size the obtained strength values originate from the fracture induced in the clamping area.

Regarding the static moduli of elasticity ( $\mathrm{MOE}_{\text {stat }}$ ), for compression and bending testing, it is observed that for all species the specimen dimensions do not influence MOE values. Literature normally lists the bending MOE. Regarding the tensile MOE, statistical analysis detects a size effect for almost all species. Whether the MOE differences are due to a real size effect or rather caused by differences in specimen shapes and differing distances between the elongation measuring points and the force introduction area cannot be answered conclusively by this study. Here also further research is needed with adjusted specimen sizes, shapes and machine set-ups.

This paper focuses on defect-free specimens. Therefore, the results must be interpreted with special care. Nonetheless, it gives useful data for the evaluation of design values of EN 338 (2010), the test set-ups defined in EN 408 (2012) and the development of hardwood adapted design specifications for Eurocode 5 (EN 1995-1-1 2010).

\section{f. Critical discussion of perpendicular to grain tension testing of structural timber - case study on the European hardwoods ash, beech and maple}

As Barret (1974) and Pedersen et al. (2003) describe, the load carrying capacity of a wood member, which a test specimen also is, is affected by many factors - mainly size, shape and stress distribution. Therefore, in this study two different specimen types are tested - the EN 408 (2012) standard specimen and a newly designed alternative. Specimen size and shape as well as force introduction are different in these two specimen types. In the specimen produced according to EN 408 (2012), the force introduction system is responsible for low strength values that cannot be seen as "real" material property. They are rather a product 
of a special stress distribution in the specimen. Still, resulting 5-percentile strength values are with approximately $4 \mathrm{~N} / \mathrm{mm}^{2}$ for beech, ash and maple wood six to seven times higher than the EN 338 (2016) design value for hardwoods. The newly designed, little perpendicular to grain tension test specimen and here especially the loading (force introduction) produces strength values that are "real" material characteristics. 5-percentile strength values range from $7.2 \mathrm{~N} / \mathrm{mm}^{2}$ for ash to $10.6 \mathrm{~N} / \mathrm{mm}^{2}$ for maple wood. Nonetheless, a need for a change of the EN 338 design value of medium-dense European hardwoods cannot be concluded only on the basis of the presented results.

More important than the design value itself, though, are the implications it has on designing structures. That means that the specimen design, the EN 338 design value, the design standard (Eurocode rules) and the assortments respectively grading must be synchronized carefully. In construction situations, where perpendicular to grain strength is critical, the stresses, which are introduced into a wood member, need to be modeled prudently. Subsequently, it needs to be tested on real structures, if the applied models hold short and long term under different climatic conditions. According to the applied model, the EN 338 (2016) design value needs to be selected respectively adapted.

The ideal perpendicular to grain tension specimen should reflect the "real" material properties and should, if possible, not be affected by an inhomogeneous stress distribution. Therefore, a prismatic specimen with axial clamping is suited better for strength determination on construction timber than the current EN 408 (2012) specimen with glued on metal plates. What also speaks for a substitution is the simple design and the easy production of such a specimen.

Perpendicular to grain tension stiffness is several times higher in this study than EN 338 (2016) design values. Both type of specimens tested in this study allow measurements of static moduli of elasticity. According to Eurocode 5 (EN 1995-1-1 2010), the compression stiffness is important for building design. Tension stiffness is only important for modeling purposes, for which this paper provides useful data.

\section{g. Review of EN 338 characteristic (perpendicular to grain compression) strength and stiffness as well as density values for European beech, ash and maple wood [Original title: Überprüfung der in DIN EN 338 angegeben (Querdruck-)Festigkeits- und Steifigkeitseigenschaften sowie Rohdichten für Buchen-, Eschen- und Ahornholz]}

The experiments of this study were carried out in accordance with EN 408 (2012). The majority of resulting perpendicular to grain compression strength values lie beneath the at that time valid EN 338 (2010) design values. The current versions of EN 384 (2016) and EN 338 (2016) consider this and for medium-dense

European hardwoods state lower characteristic values $-f_{c, 90, k}=0,010 \rho_{k}(\mathrm{EN} 384$ 2016). This paper also suggests an adjustment of EN 408 (2012) failure definition for ring-porous wood species like ash and oak and also states that it will be helpful for the design of a building to give information about deformation followed by a certain stress level (stress-strain-relationship). The mean $\mathrm{MOE}_{\text {stat }}$ values are below standard and literature values. The reasons are investigated at present. Faulty strain measurements cannot be excluded with absolute certainty. Furthermore, the size effect in compression testing perpendicular to grain is investigated at this time. 


\section{Sampling in structural timber testing}

\subsection{Definitions and standard specifications}

Like in any other biological statistics, also in structural timber testing sampling heavily influences the resulting characteristic values. The tested "sample" has to be representative for the "population", which is being analyzed. For statisticians, a "population" is a group of measurements, for which conclusions are to be drawn. Often "populations" are so large that measuring all its elements is unfeasible. Thus, only a sub-set of measurements - a "sample" - is taken. For this "sample" to be representative for the entire "population" and to subsequently reach valid conclusions, it has to be obtained in a "random" fashion. This means that each member of the "population" has to have an equal and independent chance to be selected (Zar 2010). For structural timber, a "population" can be all the boards attainable from all the trees growing in the world. It is clear that this "population" is too large for a feasible characterization. By defining the "population" with, for instance, wood species selection, round wood origin, round wood diameter range, sawing pattern and others, the "population" size is reduced. Still, measuring all of the elements of the "population" - in this case boards - is unfeasible. Thus, a "random sample" can be drawn, which then is representative for the "defined population".

Even if a structural timber "population" is well-defined, structural timber is a building material, which is characterized by a high "variability" in strength properties. For example, in paper c ash glulam lamellas ("sample") show a tension strength range from $10 \mathrm{~N} / \mathrm{mm}^{2}$ to $150 \mathrm{~N} / \mathrm{mm}^{2}$. As described in section 1.3 (Figure 4), via strength grading - i.e. sorting after strength influencing characteristics - the "variability" is minimized. Subsequently, the "variability" in each strength grading class ("sub-sample") is lower than in the total "sample". This is shown by lower "coefficients of variation" (CV). Graduated characteristic tensile strength values for each class are the consequence.

For structural timber, bending strength and stiffness as well as density "variability" need to be minimized. For glulam, the tension properties parallel to grain as well as the density are target characteristics for homogenization. EN 338 (2016) gives the characteristic strength, stiffness and density values respectively the allowable working stresses for each strength class. Here bending strength classes are optimized for an application of the wood member in an upright position under bending load. This system exists for soft- and hardwoods. The most recent version of EN 338 (2016) also gives tension strength classes and the corresponding characteristics. This enables the producer of glulam to make optimal use of the resource softwood by using an optimized grading scheme (Ridley-Ellis et al. 2016).

EN 14358 (2016) postulates that the term "population" must be clearly defined, when testing structural timber, fasteners and wood composites. EN 384 (2016) lists potential defining parameters, which can be, for example, information on sawmill, round wood diameter, country (origin) or silvicultural practice. According to EN 384 (2016), the tested "sample" has to be representative for the entire "population", i.e. all factors (known and suspected) influencing the distribution of mechanical properties have to be determined for the "population" and a "sample" with a comparable characteristics (factors) distribution has to be tested to determine characteristic mechanical properties. Via strength grading, a "sample" of a defined

origin is divided into "sub-samples". EN 384 (2016) states a minimum "sample size" of 40 specimens for determining the characteristic values for a visual strength grading "sample". The more different "subsamples" are being characterized, the higher the characteristic values are at the end, because strength modification factors $\left(\mathrm{k}_{\mathrm{n}}\right)$ are raised. 
The American standard ASTM D2915 (2017) states that a "population [...] may range from the products produced at a specific manufacturing site to all the products produced in a particular grade from a particular geographic area, during some specified interval of time". However, ASTM D2915 (2017) also emphasizes the importance of the "interests/requirements of the user" for sampling as well as analysis and use of the results. For any biostatistical analysis, it is of upmost importance to synchronize sampling and subsequent statistical analysis.

According to EN 384 (2016), "specimens" for determining perpendicular to grain strengths and shear strength have to be error-free. This is mainly due to the limited specimen size. This leads to the fact that the distributions of parameters that influence the mechanical properties perpendicular to grain and the shear strength (cracks, knots, fiber deviations, etc.) are not to be considered. Thus, the resulting "sample" (sum of specimens) is not representative for the structural timber "population". This has to be considered, when using test results in modeling or building design.

For European softwood structural timber, typical "populations" are well-known - i.e. a certain sawmill only sources round wood from a specific origin, always uses the same sawing pattern and separates logs after diameters. A sample drawn from the structural timber of this specific sawmill meets the requirement made by EN 384 (2016), EN 14358 (2016) as well as ASTM D2915 (2017). Since European hardwoods are not used intensively in construction, they are also not produced as structural timber and not traded. Therefore, for hardwoods a typical "population" is at present not definable. Studies analyzing the strength-related properties of hardwoods are thus characterized by a limited significance - i.e. the drawn conclusions are not representative. Ensuring reproducibility of parameters (factors influencing mechanical properties) and results (mechanical properties) raises significance. This can be realized by clearly defining test "samples".

Blaß et al. (2005) created the basis for the production of beech glulam after the German technical building approval DIBt (2014a). Here the grading parameter distributions were determined for 350 beech boards. Correlations between grading parameters and tension and compression characteristics parallel to grain were determined via destructive testing. This served to generate a calculation model to predict the load bearing capacity of beech glulam of different dimensions and comprised of different sorting classes. Here, the so-called "Karlsruher Modell", which was developed in the 1980s for modeling the load carrying capacity of spruce glulam, was applied and adapted. For this study, as "population" definition it was specified that highest quality (cabinet makers quality) is to be excluded on grounds of cost. Still, the tested "sample", which had a size of 350 beech boards, was a high quality. This led to the specification made by the German technical building approval DIBt (2014a) to only apply boards graded into the visual strength grading classes LS10 and better for beech glulam. This - next to other factors - leads to high price beech glulam. The "population" of the study is reproducible in the sense of EN 384 (2016) and ASTM D2915 (2017). From an economic point of view, though, it is not optimized. At present, joint research focusses on finding such "ideal populations" for low value hardwoods, which are economically optimized. In cooperation with the sawmill 'Fehrensen GmbH' (Germany), only boards produced from heart planks from grade sawing medium diameter beech round wood (compare with Torno et al. 2013) are being characterized and subsequently bending strength, MOE and density are determined. The heart planks of grade sawing are the lowest quality and thus also lowest price "sample" available at the sawmill, which is being produced constantly with the same quality and for which detailed information on round wood origin is available. 


\subsection{Sampling in publications}

\section{a. Visual and machine strength grading characteristics of six European hardwoods}

Paper a characterizes boards (glulam lamellas) of six native hardwood species (ash, beech, birch, maple, oak, lime) originating from low to medium quality and low to medium dimension logs via visual (according

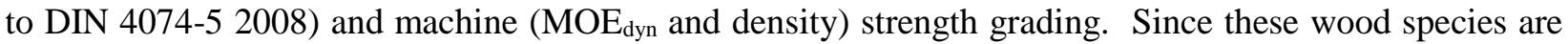
not commercially available as strength graded structural timber, the "population" respectively the selected "sample" was only defined with the phrase "market available". Another "sample" of market available dried sawn wood of one species is very likely to show different characteristics distributions. In addition, between the sampled wood species of paper a, the round wood diameter, the round wood quality, the sawing pattern as well as drying was different. Thus, making comparisons between the different species is not advised. Paper a can only show trends - like that in lime wood inbark is a very common characteristic. The discussion of this paper makes clear that a high reproducibility of characteristics - e.g. sorting parameters is one adequate definition for an "ideal population", which fulfills the requirements of EN 384 (2016), EN 14358 (2016) as well as ASTM D2915 (2017).

\section{b. Analysis of economic feasibility of ash and maple lamella production for glued laminated timber}

The papers b and $\mathbf{c}$ use - in part - the same test material ("sample") to answer questions about conversion efficiency and determine the characteristic tension strength of the production of glulam lamellas from low dimension ash and maple trees. At the beginning of the design of the test set-up stood the idea that the term "population" in structural timber testing is only a theoretical consideration, because its true nature cannot be known until all trees of a species are sawn and tested. Thus - as described above - a suitable raw material must be well defined. Any hardwood species can be turned into structural timber and subsequently used in construction. As a commercial product, the structural timber or glulam will only be applicable, when it can compete with the existing alternatives - mainly spruce structural timber (with and without finger joints) and glulam. For this reason, a low-cost round wood assortment was chosen for determining the conversion efficiency and characteristic strength values. Here, the "sub-samples" for strength grading (two origins and three different dimension) were predefined - each with the same size (number of boards). This was necessary to reduce the effect of the strength modification factors $\left(\mathrm{k}_{\mathrm{n}}\right)$ on the final characteristic strength value - i.e. for maximizing the characteristic strength (paper c). It had a negative effect on the final volume yields of paper b, though, what makes the product more expensive. Nonetheless, the holistic approach of linking the final characteristic material properties of strength classes to suitable raw material (round wood) and the conversion efficiency is consistently following EN 384 (2016) specifications for sampling. The

material tested ("sample") is representative for a possible low-cost structural timber alternative ("population") to softwood products.

\section{c. Visual and machine strength grading of European ash and maple for glulam application}

Paper c analyzes the potential of European grown ash and maple for glulam lamellas with regard to different grading techniques - visual strength grading, combined visual and machine strength grading and machine strength grading. Additionally, the mechanical properties are compared to the material property profiles 
suitable for glulam production. For each wood species, the study compares timber from different origins. These "sub-samples" show characteristic visual and mechanical properties. The target property tensile strength shows for all "sub-samples" high "coefficients of variation" (measure of variability) of over $45 \%$. To minimize this high "variability" in strength, the study divides the original "sample" and also the "subsamples" into strength grading classes with significantly lower "coefficients of variation". Overall, the study meticulously follows European harmonized standard specifications for sampling, testing and data processing to be able to integrate the attained results into European standards.

\section{d. Comparison of three systems for automatic grain angle determination on European hardwood for construction use}

Paper d evaluates the applicability of three different machine grain angle determination systems for their possible use on hardwood structural timber. Therefore, the measured grain angles were compared to a reference grain angle attained by splitting the wood. Pretests showed a very high "variability" in angle differences, which was mostly attributable to special wood characteristics like knots and grain angles. To raise the significance of the attained results, for this study, the statistics tool "stratified sampling" was chosen, which is commonly used in forest inventory. With "stratification", an original "population" is partitioned into sub-groups respectively "strata", with defined characteristics - here certain knot sizes and grain angles. This leads to a minimized within-group "variability" on the expense of the "variability" between the groups (Maniatis und Mollicone 2010). For each group ("stratum"), "systematic sampling" was carried out. In general, this procedure was successful, although for future studies the "strata" definitions need to be adjusted. The "strata" 3 and 4 did not give reasonable results for answering the desired questions. A further division of the "strata" into "sub-strata" - i.e. finer definition of knot sizes, knot characteristics or 3-dimesional information on grain angles - could have led to results with a higher informative value for each of the four "strata". "Stratification" leads to a considerable decrease in "sample size", but knowledge about the "population" is needed before designing the experimental set-up in order to find suitable "strata" definitions.

\section{e. Effect of size and geometry on strength values and MOE of selected hardwood species}

Paper e aims to provide data on the highest strength and MOE values attainable with hardwood structural timber. Therefore, the "samples" consisted only of error-free specimens. Thus, the "sample" was not representative for a possible structural timber "population". Nonetheless, this "sample" was selected, because (specimen) size effects for parallel to grain testing of wood were also to be evaluated. Paper e shows that next to the "sample size" (number of tested specimens) and the definition of sample characteristics, the experimental set-up has a major influence on the final values. Parallel to grain tension testing of $800 \mathrm{~mm}$ long Real size specimens (cross section: $100 \times 30 \mathrm{~mm}^{2}$ ) did not give conclusive size effect insights. Also, the "sample size" (number of tested specimens) for each species was with ten specimens rather low, which also complicated interpretation of results.

Many studies determining relationships between wooden structures, design stresses and material strength and stiffness show low "sample sizes" due to the high costs of testing. Evaluating, for example, the behavior of a newly developed glulam beam under different stresses, only via empirical testing is not feasible (Blaß et al. 2005). The factors influencing the behavior are numerous. Therefore, the behavior is 
often modeled. Like explained above, for any modeling of this type, knowledge about the distribution of material characteristics in the wood product on the one side as well as knowledge about the stresses resulting from the design on the other side is needed. This knowledge has to be gathered in order to develop a model that successfully stands up to empirical verification. In the case of the above-mentioned "Karlsruher Modell", this meant determining the typical respectively representative wood characteristics distribution on glulam lamellas and calculating correlations between these wood characteristics and stiffness and strength values. With this knowledge, the model simulates a possible glulam beam and via finite element modeling calculates the bending behavior respectively load carrying capacity of the glulam beam. For verification of the modeling/calculation results, only a low number of glulam beams ("sample") needs to be tested.

For testing little error-free specimens - as also performed for paper e - a "sample size" of around 40 for each group (species, specimen geometry, mechanical test) is typical. EN 384 (2016) also states this number for testing structural timber. The standard also gives the possibility to determine characteristic values for tropical hardwood construction timber by testing little, error-free specimens - a procedure, which in general has to be seen critical. Therefore, the standard states a series of conditions, which have to be met, when this procedure is applied. These conditions imply deep knowledge about the strength influencing factors. Additionally, a fixed reduction factor reduces final characteristic values, what is supposed to take account of any other unknown uncertainty.

By providing data on the upper boundary values attainable for the six tested hardwood species, paper e also gives a trend on the attainable strength values, when homogenization through further processing is applied - i.e. production of glulam or cross-laminated timber (CLT) from boards or laminated veneer lumber (LVL) from veneers.

\section{f. Critical discussion of perpendicular to grain tension testing of structural timber - case study on the European hardwoods ash, beech and maple}

Paper f provides perpendicular to grain tension strength and stiffness values for beech, ash and maple structural timber. It compares the values attained with the EN 408 (2012) specimens to those produced by a newly designed specimen.

The specimen cutting scheme ("axially assigned"; see Figure 2 of paper $\mathbf{f}$ ) led to a raised comparability of results, because for big and little specimens material with a similar density distribution was compared. The EN 384 (2016) requirements for perpendicular to grain tension specimens to be error-free lead to the fact that the distributions of other parameters that influence the mechanical properties perpendicular to grain (cracks, knots, fiber deviations, etc.) are not to be considered. When sorting parameters are not part of the procedure of determining characteristic values, their influence on the load carrying capacity needs to be addressed in the design code. For example, cracks originating from drying or occurring during service life have severe effects on tension strength perpendicular to grain as well as shear strength and their corresponding moduli of elasticity. Most literatures only consider short-term loading. Aicher and Dill-Langer (1999) evaluate the long-term behavior of spruce solid wood and report no duration of load (DOL) effect at constant climate conditions $\left(20^{\circ} \mathrm{C} ; 65 \% \mathrm{RH}\right)$. Changes in environmental conditions, though, have a big effect on cracking and therefore the final strength and stiffness under short- and longterm loading. Aicher et al. (1998) analyze this matter for spruce glulam and make suggestions for an incorporation of their findings into the design code. As technical solution they propose surface coating to reduce moisture dynamics. They also propose the reduction of the strength modification factor for 
accumulated time of loading $\left(\mathrm{k}_{\mathrm{mod}}\right)$ in service class 2 to the range $0.5-0.6$ or applying a system, which combines the design stresses from mechanical loads with climate changes. Comparable studies for hardwoods are missing so far but are very important for their applicability in construction. As proposed by Aicher et al. (1998) for spruce glulam, the results of such tests on hardwoods should not be considered by adapting EN 338 design values. They should rather be integrated into the design code (Eurocode 5) by incorporating the found dependencies in reduction factors or other models.

Micro-cracks also occur during the process of drying green lumber. They also influence perpendicular to grain tension properties heavily. This characteristic, though, cannot be quantified reliably. Thus, it can also not be included in sampling respectively sorting. This matter also has to be integrated into the design code.

\section{g. Review of EN 338 (perpendicular to grain compression) characteristic strength, stiffness and density values for European beech, ash and maple wood [Original title: Überprüfung der in DIN EN 338 angegeben (Querdruck-) Festigkeits- und Steifigkeitseigenschaften sowie Rohdichten für Buchen-, Eschen- und Ahornholz]}

Paper $\mathbf{g}$ analyzes the perpendicular to grain compression strength of European hardwoods and proposes a reduction of EN 338 (2010) design values. In the current version of EN 338 (2016), this value is set lower. In this study, the "sample sizes" per species lay around 90 specimens, which on first examination seems unnecessarily high. This high number of specimens per "sample" was chosen, though, because each "sample" was divided into "sub-samples" after testing. Comparable to tension perpendicular to grain, annual ring orientation has - amongst other factor - a high influence on compression stiffness and strength perpendicular to grain. This is owed to the cylindrical orthotropic structure of wood. Thus, for each species the original "sample" was divided into three "sub-samples" following the annual ring orientation in the failure zone. The bigger the wood member gets or the more homogenization through further processing the wood experiences, the more this influence of annual ring orientation on strength and stiffness is superimposed by other factors. In that case, the "sample" can be smaller again or new "sub-samples" can be created, which requires deeper knowledge on the strength and stiffness reducing properties of the new product. For hardwoods, the influence of wood characteristics like knots, cracks and fiber deviations on perpendicular to grain tension and compression properties as well as shear properties has not been investigated systematically. Research results only refer to error-free specimens. Thus, EN 338 (2016) design values as well as the design code do not reflect the true properties of European hardwoods concerning these characteristics. Technical building approvals do also not show representative characteristic values and design equations. Future research needs to fill this knowledge gap. 


\section{Conclusion}

At present, hardwoods are very little used in construction. This is due to technological and economical factors. Knowledge about strength characteristics of hardwood structural timber as well as strength grading of the timber is scarce - compared to softwood timber. Gluing of beech wood has been investigated scientifically, but practical solutions, which are suitable for an industrial production, have not been found so far. Other species have not been investigated at all. Next to the low final product yields, heavy machine wear, higher drying costs and rising round wood prices for hardwoods are hindering factors for an inclusion of more hardwoods into building structures. Research efforts of the last 10 - 15 years have tried to eliminate knowledge gaps in single links of the production and utilization chain of hardwood structural timber and glulam. The continued availability of spruce wood from eastern and northern Europe and Russia as well as little interest of the industry in hardwood product developments has kept spruce (respectively softwood) solid wood building product (solid wood, finger jointed solid wood, glulam, CLT) prices stable - contrary to former forecasts. Thus, the hardwood use in construction did not rise considerably in the last ten years.

The overarching aim of all papers of this dissertation was to provide data, which would contribute to a raised use of hardwoods in construction. Therefore, single research issues were identified, research set-ups were developed and the results were compressed into seven publications. These publications aimed to answer pressing questions in the production and utilization chain of hardwood solid wood construction products.

Comparing the value (grading) yield of producing glulam lamellas from low value round wood, amongst the six investigated hardwood species ash, beech, birch, maple, oak and lime, the species ash, maple and oak were identified to be best suited for an application. Excluding pith from strength grading could raise yield values considerably and would also bring up birch wood as interesting alternative. In that case, the influence of pith on strength and stiffness characteristics of the final products needs to be investigated further. Some publications focusing on hardwoods have already shown that pith has a significant influence on the bending strength of structural timber and the perpendicular to grain tension strength of glulam. On the parallel to grain tension strength of structural timber it has almost no influence. In general, the low yield in the production of strength graded hardwood lamellas is a very critical part of the production chain, which needs to be optimized. Adjusted cutting patterns as well as log lengths would raise the yield. In addition, a strength grading system, which is adjusted to the end use of the product can raise yield values and help lower the production costs. For ash and maple lamellas, strength grading results are linked to volume yield and value yield (characteristic strength values). Three grades resulting in three board tensile strength classes based on destructive tension testing are proposed. The resulting final yield is considerably higher than when grading the lamellas according to DIN 4074-5 (2008).

The grain angle (slope of grain) is an important grading criterion affecting strength grading and finger joint strength. Up to date, no machine strength grading system was available on the market, which could securely determine hardwood grain angles. This dissertation proves that for the species beech, birch, maple, oak and lime an automatic grain angle determination is possible, while for ash no functioning system is found. Furthermore, bending, compression and tension strength data derived from testing different size specimens is provided. This data is to help with the development of a hardwood adjusted design code in order to use the full potential of the hardwood products. Clear size effects independent of the species are only identified for parallel to grain bending strength. More sophisticated research set-ups that test larger data sets need to be developed to answer size effect questions. Perpendicular to grain compression testing of ash, beech and maple construction timber reveals that design value adjustments made in the current EN 338 (2016) and 
EN 384 (2016) are consistent. Tests on the same species show that the perpendicular to grain tension strength design value can be raised. More important than raising the value, though, is a synchronization of the design value with the design standard (Eurocode 5), since perpendicular to grain tensile strength of timber products depends on a series of wood intrinsic and environmental factors.

Future research initiatives by public and private entities are needed to close further knowledge gaps in the field of the utilization of hardwoods in construction. Without developments respectively improvements, a broader integration of hardwoods into building structures cannot succeed. 


\section{Literature}

Aicher S (2014) Laubholzprodukte und -anwendungen im Bauwesen - Aktueller Stand in Europa [Hardwood construction products and applications - the situation in Europe today]. In: 20. International Wood Construction Conference (IHF 2014). Garmisch-Patenkirchen

Aicher S (2016a) Glulam made of hardwoods. State of the art - species, adhesives and national/European approvals. Presentation at workshop "European hardwoods for the building sector", GarmischPatenkirchen

Aicher S (2016b) Laubholzprodukte und -anwendungen / Anschlüsse [Hardwood products and applications / Connections]. In: 9. Europäischer Kongress EBH 2016. Köln

Aicher S, Dill-Langer G (1999) Zeitstandfestigkeit von Fichten-Vollholz bei transversaler Zugbeanspruchung [Long term strength of spruce solid wood at transverse tension loading]. OttoGraf-J 10:99-112

Aicher S, Dill-Langer G, Ranta-Maunus A (1998) Duration of load effect in tension perpendicular to the grain of glulam in different climates. Holz Als Roh- Werkst 56:295-305. doi: $10.1007 / \mathrm{s} 001070050323$

Aicher S, Reinhardt H-W (2007) Delaminierungseigenschaften und Scherfestigkeiten von verklebten rotkernigen Buchenholzlamellen [Delamination characteristics and shear strength of glued red heart beech lamellas]. Holz Als Roh- Werkst 65:125-136. doi: 10.1007/s00107-006-0135-7

Augustin M (2004) Eine zusammenfassende Darstellung der Festigkeitssortierung von Schnittholz [A summary of the strength grading of sawn wood]. Diploma thesis, Graz University of Technology, Austria

Austrian Federal Environment Agency (2014) Effizente Nutzung von Holz: Kaskade versus Verbrennung [Efficient use of wood: cascade versus combustion]. Umweltbundesamt Österreich

ASTM D2915 (2017) Standard Practice for Sampling and Data-Analysis for Structural Wood and WoodBased Products. ASTM International, West Conshohocken, PA

Bacher M (2008) Comparison of different machine strength grading principles. In: COST E53 Conference 2008, Delft

Barrett JD (1974) Effect of size on tension perpendicular-to-grain strength of Douglas-fir. Wood Fiber Sci 6:126-143

Bendtsen BA, Youngs RL (1981) Machine stress rating of wood: An overview. In: Proceedings of the XVII IUFRO World congress - Division 5. Kyoto, Japan

Bengtsson C (2010) Advances and the future of grading structural timber. In: The Future of Quality Control for Wood \& Wood Products - The Final Conference of COST Action E53, Edinburgh

Blaß HJ, Denzler J, Frese M, et al (2005) Biegefestigkeit von Brettschichtholz aus Buche [Bending strength of beech glulam]. Band 1 Karlsruher Berichte zum Ingenieurholzbau, Universitätsverlag Karlsruhe, Karlsruhe 
Blaß HJ, Frese M (2006) Biegefestigkeit von Brettschichtholz-Hybridträgern mit Randlamellen aus Buchenholz und Kernlamellen aus Nadelholz [Bending strength of hybrid glulam with outer beech and inner softwood lamellas]. Band 6 Karlsruher Berichte zum Ingenieurholzbau, Universitätsverlag Karlsruhe, Karlsruhe

Denzler JK, Weidenhiller A (2015) Microwave scanning as an additional grading principle for sawn timber. Eur J Wood Wood Prod 73:423-431. doi: 10.1007/s00107-015-0906-0

DIBt (2013a) Brettschichtholz aus Buchen-Furnierschichtholz [Glulam from beech laminated veneer lumber]. German technical building approval Z-9.1-837. Holder of approval: Pollmeier Furnierwerkstoffe $\mathrm{GmbH}$, Germany. Issued by Deutsches Institut für Bautechnik (DIBt), Germany. valid until 02.12.2018

DIBt (2013b) Holz Schiller Eiche-Pfosten-Riegel-Brettschichtholz [Timber Schiller oak post and beam glulam]. German technical building approval Z-9.1-821. Holder of approval: Holz Schiller GmbH, Germany. Issued by Deutsches Institut für Bautechnik (DIBt), Germany. valid until 02.03.2018

DIBt (2013c) Sperrholz aus Buchefurnieren [Plywood from beech veneers] German technical building approval Z-9.1-841. Holder of approval: Hess \& Co. AG, Switzerland. Issued by Deutsches Institut für Bautechnik (DIBt), Germany. valid until 25.11.2018

DIBt (2014a) BS-Holz aus Buche und BS-Holz Hybridträger [Glulam and hybrid glulam made of beech]. German technical building approval Z-9.1-679. Holder of approval: Studiengemeinschaft Holzleimbau e.V., Germany. Issued by Deutsches Institut für Bautechnik (DIBt), Germany. valid until 27.10.2019

DIBt (2014b) Sperrhölzer aus Nadelholz "Metsä Wood Spruce” und Sperrhölzer aus Birkenholz "Metsä Wood Birch" [Plywood from softwood "Metsä Wood Spruce" and plywood form birch wood "Metsä Wood Birch"] German technical building approval Z-9.1-843. Holder of approval: Metsäliitto Cooperative Metsä Wood, Finnland. Issued by Deutsches Institut für Bautechnik (DIBt), Germany. valid until: not known to the author

DIBt (2016) Furnierschichtholz aus Buche zur Ausbildung stabförmiger und flächiger Tragwerke "Platte BauBuche S" und "Platte BauBuche Q" [Laminated veneer lumber form beech for plane and rodshaped load bearing structures "BauBuche S panel" and "BauBuche Q panel"]. German technical building approval Z-9.1-838. Holder of approval: Pollmeier Furnierwerkstoffe GmbH, Germany. Issued by Deutsches Institut für Bautechnik (DIBt), Germany. valid until 21.09.2018

DIN 4074-1 (2012) Strength grading of wood - Part 1: Coniferous sawn timber. German Institute for Standardization, Berlin

DIN 4074-5 (2008) Strength grading of wood - Part 5: Sawn hardwood. German Institute for Standardization (DIN), Berlin

DIN 52185 (1976) Testing of wood; compression test parallel to grain. German Institute for Standardization, Berlin

DIN 52186 (1978) Testing of wood; bending test. German Institute for Standardization, Berlin

DIN 52188 (1979) Testing of wood; determination of ultimate tensile stress parallel to grain. German Institute for Standardization, Berlin 
DIN EN 14358 (2016) Timber structures - Calculation and verification of characteristic values; German version. European Committee of Standartization, Brussels

DIN EN 14519 (2006) Solid softwood panelling and cladding - Machined profiles with tongue and groove. European Committee of Standartization, Brussels

EN 338 (2010) Structural timber - Strength classes (2016 replaced by new version). European Committee for Standardization, Brussels

EN 338 (2016) Structural timber - Strength classes. European Committee for Standardization, Brussels

EN 384 (2016) Structural timber - Determination of characteristic values of mechanical properties and density. European Committee of Standartization, Brussels

EN 408 (2010) Timber structures - Structural timber and glued laminated timber - Determination of some physical and mechanical properties. European Committee of Standartization, Brussels

EN 408 (2012) Timber structures - Structural timber and glued laminated timber - Determination of some physical and mechanical properties. European Committee of Standartization, Brussels

EN 636 (2015) Plywood - Specifications. European Committee for Standardization, Brussels

EN 975-1 (2011) Sawn timber - Appearance grading of hardwoods - Part 1: Oak and beech. European Committee for Standardization, Brussels

EN 1912 (2013) Structural timber - Strength classes - Assignment of visual grades and species. European Committee for Standardization, Brussels

EN 1995-1-1 (2010) Eurocode 5: Design of timber structures - Part 1-1: General - Common rules and rules for buildings. European Committee for Standardization, Brussels

EN 13986 (2015) Wood-based panels for use in construction - Characteristics, evaluation of conformity and marking. European Committee for Standardization, Brussels

EN 14080 (2013) Timber structures - Glued laminated timber and glued solid timber - Requirements. European Committee for Standardization, Brussels

EN 14081-1 (2016) Timber structures - Strength graded structural timber with rectangular cross section Part 1: General requirements. Eurpoean Committee for Standardization, Brussels

EN 14081-2 (2013) Timber structures - Strength graded structural timber with rectangular cross section Part 2: Machine grading; additional requirements for initial type testing. European Committee of Standartization, Brussels

EN 14081-3 (2012) Timber structures - Strength graded structural timber with rectangular cross section Part 3: Machine grading; additional requirements for factory production control. European Committee of Standartization, Brussels

EN 15497 (2014) Structural finger jointed solid timber - Performance requirements and minimum production requirements. European Committee of Standartization, Brussels 
European Union (2017) Agriculture, forestry and fishery statistics - 2017 edition. Publications Office of the European Union

Federal Ministry of Food and Agriculture (2014) Der Wald in Deutschland - Ausgewählte Ergebnisse der dritten Bundeswaldinventur [The forest in Germany - Selected results of the Third National Forest Inventory]. Bundesministerium für Ernährung und Landwirtschaft (BMEL)

Federal Ministry of Food and Agriculture (2016) Wald und Rohholzpotenzial der nächsten 40 Jahre Ausgewählte Ergebnisse der Waldentwicklungs- und Holzaufkommensmodellierung 2013 bis 2052 [Forest and raw wood potential of the next 40 years - Selected results of the forest development and raw wood availability modelling 2013 to 2052]. Bundesministerium für Ernährung und Landwirtschaft (BMEL)

FOREST EUROPE (2015) State of Europe's Forests 2015. Ministerial Conference on the Protection of Forests in Europe

Frese M (2006) Die Biegefestigkeit von Brettschichtholz aus Buche - Experimentelle und numerische Untersuchungen zum Laminierungseffekt [The bending strength of beech glulam - experimental and numerical analysis of the lamination effect]. Band 5 Karlsruher Berichte zum Ingenieurholzbau, Universitätsverlag Karlsruhe, Karlsruhe

Frese M, Blaß HJ (2007) Characteristic bending strength of beech glulam. Mater Struct 40:3-13. doi: $10.1617 / \mathrm{s} 11527-006-9117-9$

Frühwald A, Ressel JB, Bernasconi A, et al (2003) Hochwertiges Brettschichtholz aus Buchenholz [High quality glulam made of beech wood]. Final report. Zentrum Holzwirtschaft, Universität Hamburg, Hamburg

Frühwald A, Schickhofer G (2005) Strength grading of hardwoods. In: Proceedings of the 14th International Symposium on Nondestructive Testing of Wood, Hanover

Galligan WL, McDonald KA (2000) Machine grading of lumber - Practical concerns for lumber producers. U.S. Department of Agriculture, Forest Service, Forest Products Laboratory, Madison, WI

German Federal Ministry of Food and Agriculture (2017) Klima schützen. Werte schaffen. Ressourcen effizient nutzen. Charta für Holz 2.0 [Climate protection. Value creation. Efficient resource use. Charta for wood 2.0]. Bundesministerium für Ernährung und Landwirtschaft (BMEL)

Glos P (1978) Zur Bestimmung des Festigkeitsverhaltens von Brettschichtholz bei Druckbeanspruchung aus Werkstoff- und Einwirkungskenngrößen - Berichte zur Zuverlässigkeitstheorie der Bauwerke [On the determination of strength behaviour of glulam under tension stress from characteristic material properties and external forces - Reports on the reliability theory of buildings]. Holzforschung München, Technical University Munich, Munich

Glos P (1995) Festigkeitssortierung [Strength grading]. In: Blaß HJ, Görlacher R, Steck G (eds) Informationsdienst Holz. Holzbauwerke nach Eurocode 5. [1] Step 1. Bemessung Baustoffe. [2] Step 2. Bauteile - Konstruktionen - Details. [3] Step 3. Grundlagen - Entwicklungen Ergänzungen. [4] Step 4. Eurocode 5 - Nationales Anwendungsdokument. Arbeitsgemeinschaft Holz e.V., Düsseldorf 
Glos P, Lederer B (2000) Sortierung von Buchen- und Eichenschnittholz nach der Tragfähigkeit und Bestimmung der zugehörigen Festigkeits- und Steifigkeitskennwerte [Strength grading of beech and oak lumber and determination of characteristic strength and stiffness values]. Final report. Holzforschung München, Technical University Munich, Munich

Glos P, Näher T (2005) Aufnahme der einheimischen Holzarten Buche (Fagus sylvatica), Eiche (Quercus petraea, Quercus robur) und Douglasie (Pseudotsuga menziesii) in die europäische Norm EN 1912 [Inclusion of the native wood species beech, oak and Douglas fir in the European standard EN 1912]. Holzforschung München, Technical University Munich, Munich

Glos P, Torno S (2008) Aufnahme der einheimischen Holzarten Ahorn, Esche und Pappel in die europäische Norm EN 1912: „Bauholz - Festigkeitsklassen - Zuordnung von visuellen Sortierklassen und Holzarten" [Inclusion of tha native wood species maple, ash and poplar in the European standard EN 1912: "Structural timber - Strength classes - Assignment of visual grades and species"]. Holzforschung München, Technical University Munich, Munich

Hanhijärvi A, Ranta-Maunus A (2008) Development of strength grading of timber using combined measurement techniques. Report of the Combigrade-project - phase 2, VTT Publications 686, Espoo

Hunger F, Van de Kuilen J-W (2015) Festigkeitsprofile von heimischen Laubhölzern [Strength profiles of native hardwoods]. Holzforschung München, Technical University of Munich, Munich

Isopp A (2016) Was die Fichte für die Industrie, ist die Buche für die Ökologie - Waldbewirtschaftung in Zeiten des Klimawandels [What the spruce means for the industry, the beech means for ecology Forest management in times of climate change]. Zuschnitt 64 - Laubholz

Jeitler G (2016) Personnel Communication

Jeitler G, Augustin M (2016) Ist Birke die bessere Buche? Mechanische Eigenschaften und Referenzprojekte aus Birke / BSH \& BSP [Is birch the better beech? Mechanical properties and reference projects from beech / glulam and CLT]. In: 20. International Wood Construction Conference (IHF 2014). Garmisch-Patenkirchen

Jiang Y (2016) Brettschichtholz aus Buche - Langzeitmessung zur Bestimmung von Feuchtegradienten in Holzbauteilen der Nutzungsklasse 1 und 2 [Glulam from beech wood - long-term measurement for determination of moisture gradients in wood components in the use class 1 and 2]. Final report. Holzforschung München, Technical University Munich, Munich

Kleinschmit A (2012) Französische Strategien zur innovativen Wertschöpfung des heimischen Laubholzpotenzials [French strategies for an innovative utilization of the native hardwood potential]. In: Gülzower Fachgespräche stoffliche Nutzung von Laubholz, Würzburg

Knorz M, Neuhaeuser E, Torno S, van de Kuilen J-W (2015) Influence of surface preparation methods on moisture-related performance of structural hardwood adhesive bonds. Int J Adhes Adhes 57:40-48. doi: 10.1016/j.ijadhadh.2014.10.003

Knorz M, Schmidt M, Torno S, Kuilen J-W (2014) Structural bonding of ash (Fraxinus excelsior L.): resistance to delamination and performance in shearing tests. Eur J Wood Wood Prod 72:297-309. doi: 10.1007/s00107-014-0778-8 
Kollert W, Lebedys A (2012) Globale Laub- und Nadelholzmärkte mit Schwerpunkt Europa [Global hardwood and softwood markets with focus on Europe]. In: Gülzower Fachgespräche stoffliche Nutzung von Laubholz, Würzburg

Kovryga A, Schlotzhauer P, Militz H, Van de Kuilen J-W (2019) Visual and machine strength grading of European ash and maple for glulam application. Holzforschung 0(0). doi: 10.1515/hf-2018-0142

Kovryga A, Stapel P, Van De Kuilen JW (2016) Tensile strength classes for hardwoods. Paper 49-10-1. In: Proceedings of 49th INTER \& CIB Meeting. Graz, Austria

Krackler V, Keunecke D, Niemz P (2010) Verarbeitung und Verwendungsmöglichkeiten von Laubholz und Laubholzresten [Processing and utilization possibilities for hardwood and hardwood residues]. IfB Projektstudie, Swiss Federal Institute of Technology Zurich, Zurich

Krzosek S, Bacher M (2011) Aktueller Stand der maschinellen Festigkeitssortierung von Schnittholz in Polen und in Europa [Status quo of machine strength grading of sawn wood in Poland and Europe]. For Wood Technol 74:254-259

Lennartz MW, Jacob-Freitag S (2016) Neues Bauen mit Holz: Typen und Konstruktionen [New building with wood: types and constructions]. Birkhäuser Verlag GmbH, Basel

Madsen B (1992) Structural behavior of timber. Timber Engineering Ltd, North Vancouver

Maniatis D, Mollicone D (2010) Options for sampling and stratification for national forest inventories to implement REDD+ under the UNFCCC. Carbon Balance Manag 5:9. doi: 10.1186/1750-0680-5-9

Mantau U, Döring P, Hiller D (2013) Holzeinsatz im Bauwesen - Verwendungsstrukturen nach Gebäuden und Gewerken [Wood in construction - Structure of use seperated after buildings and building parts]. In: Weimar H, Jochem D (eds) Holzverwendung im Bauwesen - Eine Marktstudie im Rahmen der „Charta für Holz“. Johann Heinrich von Thünen-Institut, Hamburg

National Hardwood Lumber Association (2007) Rules for the measurement and inspection of hardwood and cypress. National Hardwood Lumber Association (NHLA), Memphis, TN

NF B 52-001 (2011) Règles d'utilisation du bois dans les construc tions; Classement visuel pour employ en structure pour les principales essences résineuses et feuillues [Rules for the use of wood in buildings; Visual classification for structural application for the main softwood and hardwood species]. AFNOR. Saint-Denis

Norrenbrock M (2017) Personnel communication

Ohnesorge D, Richter K, Becker G (2010) Influence of wood properties and bonding parameters on bond durability of European Beech (Fagus sylvatica L.) glulams. Ann For Sci 67:601

OiB (2013a) Legno strutturale classificato secondo la resistenza - tronchi squadrati con smusso per utilizzo come elementi portanti di edifici e opere d'ingegneria civile [Structural timber classified according to resistance - square-edged logs with wane for use as load bearing elements in structural engineering] ETA-12/0540 European Technical approval. Holder of approval: Consorzio Servizi Legno - Sughero, Italy. issued by Austrian Institute of Construction Engineering (OiB), Austria. valid until 30.01.2018 
OiB (2013b) Sierolam - Glued laminated timber of chestnut. ETA-13/0646 European Technical approval. Holder of approval: Siero Lam S.A., Spain. issued by Austrian Institute of Construction Engineering (OiB), Austria. valid until 27.06.2018

OiB (2013c) VIGAM - Glued laminated timber of oak. ETA-13/0642 European Technical Approval. Holder of approval: Elaborados y Fabricados Gámiz S.A., Spain. issued by Austrian Institute of Construction Engineering (OiB), Austria. valid until 27.06.2018

OiB (2015) Brettshichtholz aus Laubholz - Buchenfurnierschichtholz für tragende Zwecke [Glulam from hardwood- beech laminated veneer lumber for load bearing applications]. ETA-14/0354 European Technical approval. Holder of approval: Pollmeier Furnierwerkstoffe $\mathrm{GmbH}$. issued by Austrian Institute of Construction Engineering (OiB), Austria. valid until: not specified

Olsson A, Oscarsson J, Serrano E, et al (2013) Prediction of timber bending strength and in-member cross-sectional stiffness variation on the basis of local wood fibre orientation. Eur J Wood Wood Prod 71:319-333

Pedersen MU, Clorius CO, Damkilde L, Hoffmeyer P (2003) A simple size effect model for tension perpendicular to the grain. Wood Sci Technol 37:125-140. doi: 10.1007/s00226-003-0168-6

Ridley-Ellis D, Stapel P, Baño V (2016) Strength grading of sawn timber in Europe: an explanation for engineers and researchers. Eur J Wood Wood Prod 74:291-306. doi: 10.1007/s00107-016-1034-1

Sachs L (1982) Statistische Methoden [Statistical methods]. Springer, Berlin, Heidelberg

Sathre R, Gustavsson L (2009) A state-of-the-art review of energy and climate effects of wood product substitution. Mid Sweden University, Östersund

Sauter U (2016) WP 1: Hardwood resources in Europe - Standing stock and resource forecasts. Presentation at workshop "European hardwoods for the building sector", Garmisch-Patenkirchen, Germany

Schickhofer G, Augustin M (2001) EU-Project INTELLIWOOD - Final Report; Working Package 3: Strength Correspondence. Graz, Austria

Schmidt M, Glos P, Wegener G (2010) Verklebung von Buchenholz für tragende Holzbauteile [Gluing of beech for load bearing elements]. Eur J Wood Wood Prod 68:43-57

Seintsch B, Rosenkranz L (2014) Mögliche Wirkungen des Waldnaturschutzniveaus auf die holzbasierte Wertschöpfung in Deutschland [Possible effect of the level of forest conservation on the woodbased added value in Germany]. 3. Workshop der Dialogplattform Wald: „Wettbewerb um das Holz: Auswirkungen von Schutzmaßnahmen und Rohstoffpolitiken auf Art und Umfang des Holzaufkommens - wie reagieren die Abnehmer? “, Brilon

Seintsch B, Weimar H (2012) Actual situation and future perspectives for supply and demand of hardwood in Germany. In: Nemeth R, Teischinger A (eds) The 5th Conference on Hardwood Research and Utilisation in Europe 2012. University of West Hungary Press, Sopron

Stapel P (2014) Strength grading of timber with regard to different grading methods. Doctoral thesis, Holzforschung München, Technical University Munich, Munich 
Steiger R, Franke S, Frangi A (2014) Brettschichtholz aus Buche und Verbindungen in BuchenBrettschichtholz - Workshops zur Erhebung des aktuellen Wissensstandes in Deutschland, Österreich und der Schweiz [Beech glulam and connections in beech glulam - Workshop for determination of state of knowledge in Germany, Austria and Switzerland]. Project report, Bundesamtes für Umwelt (BAFU), Zurich

Studiengemeinschaft Holzleimbau e.V., Überwachungsgemeinschaft Konstruktionsvollholz e.V. (2017) Merkblatt zur ansetzbaren Rechenwerten für die Bemessung nach DIN EN 1995-1-1 für Vollholz, keilgezinktes Vollholz, Balkenschichtholz (Duobalken® / Triobalken®), Brettschichtholz, Brettsperrholz, Furnierschichtholz [Data sheet on calculation values for designing after DIN EN 1995-1-1 for solid wood, finger-jointed solid wood, Duobalken ${ }^{2}$ Triobalken ${ }^{\circledR}$, glulam, CLT, LVL]. Studiengemeinschaft Holzleimbau e.V., Überwachungsgemeinschaft Konstruktionsvollholz e.V., Wuppertal

Swiss Federal Department of Environment (2017) Ressourcenpolitik Holz - Strategie, Ziele und Aktionsplan Holz [Resource policy wood - Strategy, objectives, action plan wood]. Schweizer Bundesamt für Umwelt (BAFU)

TG1 (2017a) APPROVED GRADING REPORT No. AGR/6/FR/119

TG1 (2017b) APPROVED GRADING REPORT No. AGR/7/FR/79

Torno S, Jentsch A, Lattke F (2017) Konstruktive Bauprodukte aus europäischem Laubholz [Construction products from European hardwood] Informationsdienst Holz spezial, Informationsverein Holz e.V., Düsseldorf

Torno S, Knorz M, Van de Kuilen JW (2013) Supply of beech lamellas for the production of glued laminated timber. In: 4th International Scientific Conference on Hardwood Processing, Florence

Torno S, Van de Kuilen JW (2010) Esche für tragende Verwendungen - Festigkeitseigenschaften visuell sortierten Eschenholzes [Ash for load bearing use - strength properties of visually graded ash lumber]. LWF Aktuell 77:18-19

UNI 11035-1/-2 (2010) Legno strutturale - Classificazione a vista dei legnami secondo la resistenza meccanica - parte 1-2 [Structural timber - Visual strength grading - part 1-2]. Italian Organization for Standardization, Milano

Van de Kuilen JW, Torno S (2014) Untersuchungen zur Bereitstellung von Lamellen aus Buchen- und Eschenholz für die Produktion von Brettschichtholz [Studies on the supply of lamellas for the production of glulam from beech and ash wood]. Final report X37, Holzforschung München, Technical University Munich, Munich

Volkmer T, Lehman M, Clerc G (2017) Brettschichtholz aus Buche: Keilzinkenverbindung und Flächenverklebung [Glulam from beech: Finger-joints and surface gluing]. In: 23. International Wood Construction Conference (IHF 2017), Garmisch-Patenkirchen

Wehrmann W, Torno S (2015) Laubholz für tragende Konstruktionen - Zusammenstellung zum Stand von Forschung und Entwicklung [Hardwood for load bearing structures - Compilation of state of research and development]. Cluster-Initiative Forst und Holz in Bayern gGmbH, Freising

Weibull W (1939) A statistical theory of the strength of material. The Royal Swedish Institute for Engineering Research, Proceedings No. 151, Stockholm 
Weimar H, Seintsch B (2012) Laubholz in Deutschland - Auf welchen Markt trifft das Potenzial? [Hardwoods in Germany - What is the market for the potential?]. In: Gülzower Fachgespräche stoffliche Nutzung von Laubholz, Würzburg

Welling J (2012) Unterschiede zwischen Laub- und Nadelholz und deren Einfluss auf die Verarbeitung und Verwendung [Differences between hard- and softwoods and their influence on processing and use]. In: Gülzower Fachgespräche stoffliche Nutzung von Laubholz, Würzburg

Wenighofer G (2016) Personel communication

Zar JH (2010) Biostatistical Analysis. Prentice Hall, New Jersey 


\section{Paper annex}

a. Schlotzhauer P, Bollmus S, Militz H (2018) Visual and machine strength grading characteristics of six European hardwoods. holztechnologie 59(6):5-14

b. Schlotzhauer P, Kovryga, Emmerich L, Van de Kuilen JW, Militz H (2019) Analysis of economic feasibility of ash and maple lamella production for glued laminated timber. Manuscript submitted to forests

c. Kovryga A, Schlotzhauer P, Stapel P, Militz H, Van de Kuilen JW (2019) Visual and machine strength grading of European ash and maple for glulam application. Holzforschung 0(0). doi: 10.1515/hf-2018-0142

d. Schlotzhauer P, Wilhelms F, Lux C, Bollmus S (2018) Comparison of three systems for automatic grain angle determination on European hardwood for construction use. European Journal of Wood and Wood Products 76:911-923. doi: 10.1007/s00107 018-1286-z

e. Schlotzhauer P, Nelis PA, Bollmus S, Gellerich A, Militz H, Seim W (2015) Effect of size and geometry on strength values and MOE of selected hardwood species. Wood Material Science \& Engineering 12(3):149-157. doi: 10.1080/17480272.2015.1073175

f. Schlotzhauer P, Ehrmann A, Bollmus S, Militz H (2018) Critical discussion of perpendicular to grain tension testing of structural timber - case study on the European hardwoods ash, beech and maple. Wood Material Science \& Engineering. doi: $10.1080 / 17480272.2019 .1596157$

g. Schlotzhauer P, Bollmus S (2016) Überprüfung der in DIN EN 338 angegeben (Querdruck-)Festigkeits- und Steifigkeitseigenschaften sowie Rohdichten für Buchen-, Eschen- und Ahornholz [Review of EN 338 characteristic (perpendicular to grain compression) strength and stiffness as well as density values for European beech, ash and maple wood]. Conference transcipt of 6. Doktorandenkolloquium „Holzbau Forschung und Praxis“, Stuttgart 


\section{Paper a}

Visual and machine strength grading characteristics of six European hardwoods 


\section{Visual and machine strength grading characteristics of six European hardwoods}

\section{Philipp Schlotzhauer, Susanne Bollmus, Holger Militz}

To achieve a more prominent integration of native hardwoods into construction as load-bearing elements it is necessary to evaluate their suitability on a technological and an economical basis. This paper provides information on the strength grading characteristics of six European hardwood species. Market available dried sawn wood assortments were selected as research material. Lamellas with a cross section of $100 \times 30 \mathrm{~mm}^{2}$ and lengths up to three meters were strength graded visually according to DIN 4074-5 (2008). Additionally, dynamic modulus of elasticity $\left(\mathrm{MOE}_{d y n}\right)$ and density were determined. Out of the investigated collectives, the collectives of the species ash, maple and European oak showed the best lamella qualities. Many big knots, that led to downgrading characterized the beech and lime collectives. In lime, inbark was also abundant, which makes it less suitable for an application in construction. The influence of pith on mechanical properties is to be investigated, since in the maple, birch and ash collectives, pith was the main downgrading criterion. Ash exhibits the highest $\mathrm{MOE}_{d y n}$ values, but also the highest value variation. The highest densities were measured in the beech and oak collectives. At present, the market does not provide dried sawn wood assortments suitable as hardwood structural timber. Suitable assortments might come from round wood, which is at present consumed for energy production or from commercializing co-products from high quality products.

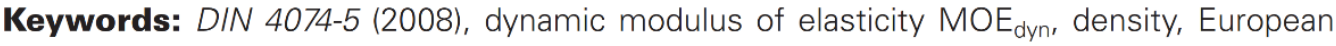
hardwood, knot size, pith

Introduction

From 2002 to 2012, the German hardwood standing stock grew $7 \%$ and in the year of the inventory (2012) made up $43 \%$ of the total standing stock (Federal Ministry of Food and Agriculture, 2014). In contrast, in the year 2011, the German annual fellings were made up of about $75 \%$ coniferous round wood (Seintsch and Weimar, 2012). Scientific predictions estimate that in the next 35 years the standing stock of hardwoods will rise even further, due to unused potentials (Weimar and Seintsch, 2012). A possible application of these unused resources are load-bearing elements - as structural timber (solid wood), finger-jointed structural timber, glulam, CLT, and others. Mantau et al. (2013) estimate that in German house building structures only $12.6 \%$ of the total wood consumption comprises native hardwoods. Fig. 1 shows the hardwood and softwood distribution separated after trade respectively building part.

The upper five products are load-bearing elements. Here hard- woods play almost no role. The reasons for this are numerous. They are of technological (e.g. gluing, machining and strength prediction problematic) and economical (lower yields, higher drying costs etc.) nature. Also, scientific data as well as expert knowledge on the use of hardwoods in construction is scarce. For centuries, though, all over Europe wooden structures made of hardwoods have been part of residential buildings and bridges. During the middle ages, mainly oak solid wood was used for framework constructions in Central Europe, while in Southern Europe sweet chestnut was used. Architectural witnesses of these times still exist. In an impressing manner, these buildings prove the applicability of the material - regarding durability and strength properties. The less durable species poplar can also still be found in old farm buildings in Central and Southern Europe. Here, it was used as cladding, but also as structural timber(Grosser, 2006). Glos and Torno (2008) have proven that German poplar (Populus nigra) structural timber 


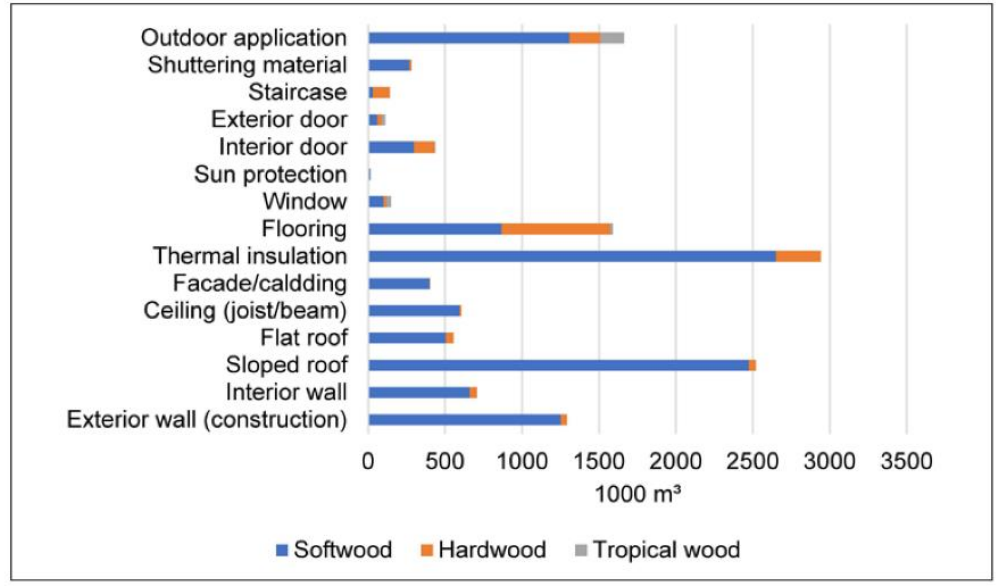

Fig. 1: Hardwood and softwood (plus tropical wood) distributions and volumes in German building structures separated after trade respectively building part (Mantau et al., 2013, translated) Abb. 1: Laub- und Nadelholznutzung (plus Tropenholz) im deutschen Baugewerbe unterteilt nach Gewerken shows similar strength and stiffness values as spruce wood. It can be visually strength graded into the strength classes $\mathrm{C} 22$ and $\mathrm{C} 27$, i. e. it exhibits characteristic bending strengths of $22 \mathrm{~N} / \mathrm{mm}^{2}$ respectively $27 \mathrm{~N} / \mathrm{mm}^{2}$. Also, ash wood can be found in 300 years old framework houses - mainly as structural timber in inside walls. At the end of the $19^{\text {th }}$ century it was also widely used - next to oak wood - as load-bearing element in the construction of railway vehicles and later in automotive vehicles (Grosser; 2002).

Before the invention of steel, wood was the only building material, which was able to carry high tension and bending loads. Along with the industrialization of the $19^{\text {th }}$ century, the use of steel and later steel in combination with concrete forced wood out of many load-bearing applications. With the invention of glulam in 1906 by Otto Hetzer, timber engineering gained new momentum (Lennartz and Jacob-Freitag, 2016). The new glued products were mainly produced form spruce and fir wood, since gluing and machining of these species is least complicated (Aicher, 2014). In modern timber engineering, hardwoods like oak played nearly no role. It was only at the turn of the century, when the works of Glos and Näher (2005) as well as Glos and Lederer (2000) eased the use of oak as structural timber according to current harmonized European regulations. With the DIN 4074-5 (2008), the first German visual strength grading standard was developed in the year 2000 (Glos and Lederer, 2000). Machine strength grading for hardwood is at present not even in use. Since the development of the DIN 4074-5 (2008), the German hardwood species ash, beech, maple, oak and poplar were introduced into the EN 1912 (2013). Thus, when strength graded, they can be used as structural timber (solid wood without finger-joints). At present, though, German National Application Documents (NAD) only allow the use of beech and oak. Also, German beech and oak can be used in glulam (according to German technical building approvals Z-9.1-679 and Z-9.1-821). Nevertheless, these hardwood species are hardly used in construction, since the described products are at present economically not competitive.

Glos and Torno (2008) claim that due to costs, only low to me- dium dimension logs of low to normal quality are worth considering for load-bearing elements. Frese and Riedler (2010) postulate that for beech glulam, to be an economic alternative to softwood glulam, a high percentage of the strength graded boards has to fulfil the requirements of the visual sorting classes LS10 and LS13 (and better) of the German visual hardwood strength grading standard 4074-5 (2008). These two requirements seem to contradict each other - attaining high quality boards from low quality logs.

This paper aims to characterize boards (lamellas) originating from low to medium quality and low to medium dimension logs via visual (according to DIN 4074-5, 2008) and machine (MOE ${ }_{\text {dyn }}$ and density) strength grading.

For this purpose, the following six species were investigated: - maple (Acer spp.),

- birch (Betula pendula),

- beech (Fagus sylvatica),

- ash (Fraxinus excelsior),

- European oak (Quercus spp.) and

- lime (Tilia $\mathrm{spp}$.).

Since these wood species are not traded as structural timber, but mostly as material for the furniture industry (amongst others), market available wood mostly exceeds the desired qualities. Thus, finding suitable assortments for this study presented a challenge. The same was reported by Frese and Riedler (2010) and Glos and Torno (2008). This shows that the availability and consequently also the use situation has not changed since 2010. Based on the conducted sorting, this study aims to answer the following questions:

1. When using market available, low to medium quality sawn hardwood timber assortments, what is the quality yield concerning strength grading?

2. Are all visual sorting parameters named by the $D I N$ 4074-5 (2008) clearly attainable/determinable for the selected hardwoods?

3. Do the different hardwood species show specific and or typical characteristics respectively characteristics distributions? 


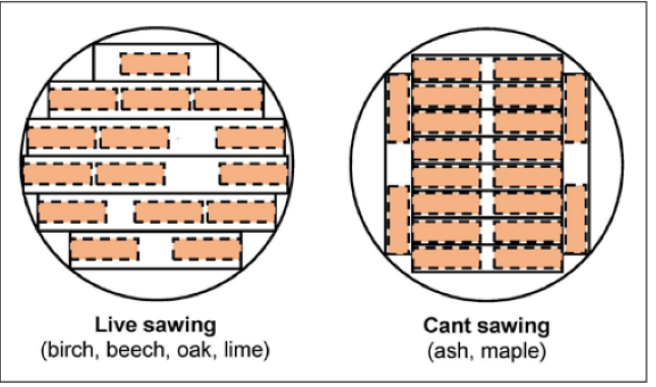

Fig. 2: Sawing patterns employed for the sourced raw material and arrangement of final lamellas (beige)

Abb. 2: Verwendete Schnittbilder und Anordnung der finalen Lamellen (beige)

Material

It was aimed to source the raw material for hardwood glulam lamellas from typical assortments, available on the present sawn timber market. For economic reasons, the round wood qualities suitable for such a product are classes $\mathrm{C}$ and $\mathrm{D}$ (according to $R V R, 2015$ ). The round wood sections of all six species originated from natural mixed forest stands in Central Germany (West Thuringia and Northern Hesse), where they were selected randomly. The species birch, beech, oak and lime were sourced from local sawmills as kiln-dried live sawn timber (see Fig. 2) with a thickness of $50 \mathrm{~mm}$. The round wood sections of beech, oak and lime had mid-diameters between $400 \mathrm{~mm}$ and $500 \mathrm{~mm}$. The birch sections had mid-diameters between $200 \mathrm{~mm}$ and $350 \mathrm{~mm}$. The unedged sawn timber was square-edged with a sliding-table saw to boards with a width of $110 \mathrm{~mm}$, starting from the edges, leaving the centre part of each board as scrap piece. Subsequently the boards were planed to their final dimensions of $100 \times 30 \mathrm{~mm}^{2}$ (red boards in Fig. 2). The maple and ash raw material was sourced from a sawmill, that produces square-edged timber for the parquet flooring industry. The round wood sections utilized in this sawmill exhibit mid-diameters of $200 \mathrm{~mm}$ to $350 \mathrm{~mm}$. The used logs were of minor quality (C and D according to $R V R, 2015$ ). This raw material was thought as ideal for glulam lamellas. In this sawmill the logs are cant sawn, resulting in a specific sawing pattern (see Fig. 2). The dried square-edged boards $\left(40 \times 110 \mathrm{~mm}^{2}\right)$ were also planed to the final dimensions of $100 \times 30 \mathrm{~mm}^{2}$. The sawn timber had a length of $3.10 \mathrm{~m}$. Boards with intensive bowing were trimmed, so that subsequent planning resulted in fully planed lamellas. The resulting numbers of lamellas (sample size) per species and the corresponding length distribution are shown in Fig. 3.

Since it was already clear at the beginning of the project, that one focus of the research would be set on the species ash and maple, for these two species the most lamellas were provided (255 and 286). Moreover, for the other species sufficient dried timber from $\mathrm{C}$ and $\mathrm{D}$ quality logs was either not available at all or not available for an acceptable price (similar to high quality sawn timber prices), which would make the final product too expensive for an application in construction.

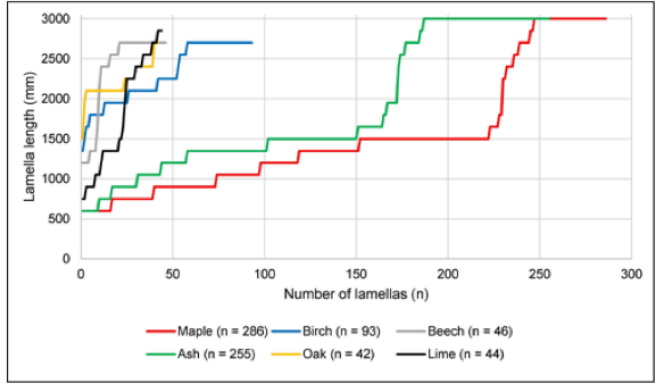

Fig. 3: Distribution of lamella length and corresponding number per species ( $\mathbf{n}=$ total sample size)

Abb. 3: Kumulative Verteilung der Lamellenlängen und korrespondierende Anzahl pro Holzart ( $n$ = Gesamtlamellenzahl)

\section{Methods}

\section{Visual strength grading}

The visual sorting criteria for strength grading were determined according to DIN 4074-5 (2008) for boards for glulam production and according to DIN 1310 (1997). Knots were measured, starting at a knot width of $5 \mathrm{~mm}$. Since visual grain angle determination with a scriber or by evaluating drying cracks is seen very critical, this criterion was excluded from this study (see introduction and also Schlotzhauer et al., 2018c). Since often the more aesthetic appearance of hardwoods in comparison to softwoods is pointed out, the criterion coloured heartwood is included in the data collection. For a randomly selected subset (approximately 20 lamellas per species), the visual strength grading is carried out by two different graders to evaluate the subjectivity of visual grading on hardwoods.

\section{Machine sorting}

Lamella moisture contents (MCs) were estimated with the capacitance method with a Brookhuis Micro-Electronics device $(E N 13183-3,2005)$ two times per lamella $(50 \mathrm{~cm}$ away from ends). Prior to measurement each lamella was stored in $20^{\circ} \mathrm{C}$ and $65 \%$ relative humidity until equilibrium moisture content was reached. At this MC the density was determined according to DIN 52182 (1976).

The dynamic modulus of elasticity $\left(\mathrm{MOE}_{\mathrm{dyn}}\right)$ was determined with two devices:

(A) Timber Grader MTG (Brookhouis Micro-Electronics) and

(B) GrindoSonic (JW Lemmens AIF Management BVBA).

Both devices measure the natural frequency from longitudinal oscillation. Therefore, each lamella is placed on supports as depicted in Fig. 4. A hammer in the Timber Grader MTG (device on left side) triggers the longitudinal oscillation, which is then measured by both devices (via microphone or piezoelectric sensor). 


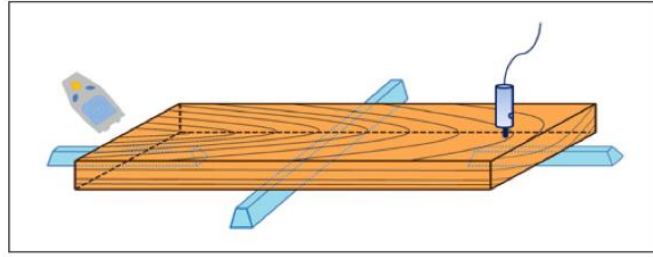

Fig. 4: $\mathrm{MOE}_{\mathrm{dyn}}$ measurement set-up (Hentschel and Butter, 2014)

Abb. 4: Versuchsaufbau zur Bestimmung des dynamischen E-Moduls MOE $E_{d y n}$ (Hentschel and Butter, 2014)

This procedure follows the descriptions of Görlacher (1990). $\mathrm{MOE}_{\mathrm{dyn}}\left(\mathrm{N} / \mathrm{mm}^{2}\right)$ is then calculated according to Eq. 1:

$$
M O E_{d y n}=4 \cdot l^{2} \cdot \rho \cdot f^{2} \cdot 10^{-6}
$$

Whereas

- $1=$ lamella length $(\mathrm{m})$,

- $\rho=\operatorname{density~}\left(\mathrm{kg} / \mathrm{m}^{3}\right)$ and

- $\mathrm{f}=$ natural frequency (first order) $(\mathrm{Hz})$.

\section{Results and discussion}

\section{Visual strength grading}

Fig. 5 visualizes the distribution of sorting classes, when sorting the six hardwood collectives visually according to $D I N$ 4074-5 (2008) for boards.

The proportion of rejects is with around $20 \%$ equally high for maple, birch, beech and ash. Oak shows less than $10 \%$ rejects, while lime exhibits almost $35 \%$ rejects. Fig. 6 shows the visual sorting class distribution, when the criterion pith is excluded from sorting.

For maple, birch and ash, the main rejection criterion is pith, while the collectives of oak, lime and beech are hardly affected

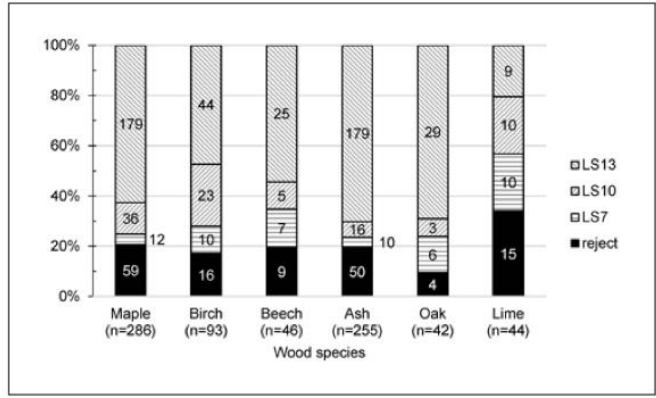

Fig. 5: Visual strength grading class (according to DIN 4074-5, 2008) distribution for the six selected hardwood collectives Abb. 5: Sortierergebnis der visuellen Festigkeitssortierung lgemäß DIN 4074-5, 2008) für die sechs ausgewählten Holzarten

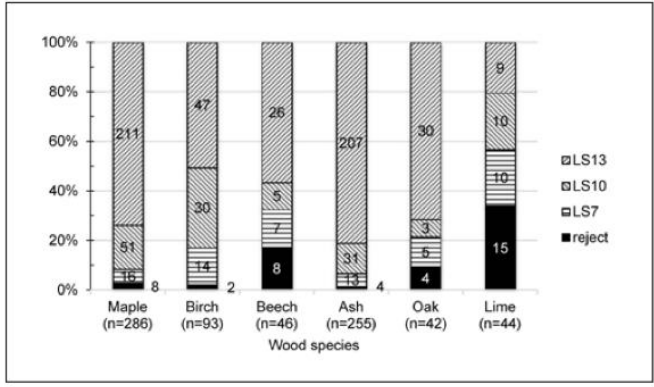

Fig. 6: Visual strength grading class (according to DIN 4074-5, 2008) distribution for the six selected hardwood collectives without considering pith

Abb. 6: Sortierergebnis der visuellen Festigkeitssortierung (gemäß DIN 4074-5, 2008) für die sechs ausgewählten Holzarten ohne Berücksichtigung des Parameters Markröhre

by this criterion. In $D I N 4074-5$ (2008), oak takes a special position, because here pith containing boards are not rejected, but sorted into sorting class LS7. Since only one of the 42 oak boards contain pith, this distinction does not have a drastic effect on the sorting class distribution. For ash and maple, Glos and Torno (2008) prove that pith has a significant influence on the bending strength of square-edged lumber. They also stress the fact that the appearance of pith is often accompanied by bows, twists and cracks. Similar results are presented by Glos and Lederer (2000) for beech and oak square-edged lumber. Hübner (2013) proves the significant influence of pith on the tension strength perpendicular to grain of ash glulam. Kovryga et al. (2018) report a low impact of pith on tension properties parallel to grain. Thus, when allowing pith, it will be important to distinguish the end use of the structural timber. The more frequent occurrence of pith in maple, birch and ash lamellas compared to the other investigated species is mainly owed to stochastic reasons. Mean maple, birch and ash log diameters were much lower. Furthermore, ash and maple lamellas were sawn using a different cutting pattern (cant sawing), which compared to other sawing patterns (e. g. grade sawing) are known to produce higher amounts of pith containing boards. The log quality also plays an important role. For example, intensive bowing of logs also leads to more pith containing lamellas (Schlotzhauer et al., 2018b). For this study, though, information on the log quality was not collected. For ash, the typical so-called "wandering pith" is a further explanation of the high proportion of pith containing lamellas (Ehlebracht, 2000; Torno and van de Kuilen, 2010). In birch, cracks form especially in the vicinity of pith. In beech boards, mainly big single knots lead to a rejection. Abundant in all examined hardwood species is the occurrence of knots that end inside the board. This special case occurs, when a branch brakes off the tree and is overgrown. Here the dimensions and the course of the knot through the board are hard to impossible to distinguish.

Tab. 1 summarizes the visual sorting results for each wood species separately - following the criteria list of Tab. 3 of DIN 4074-5 (2008). 


\begin{tabular}{|c|c|c|c|c|c|c|c|}
\hline \multirow{2}{*}{$\begin{array}{c}\text { Sorting crite- } \\
\text { ria }\end{array}$} & \multicolumn{6}{|c|}{ Wood Species } & \multirow{2}{*}{ Unit } \\
\hline & Maple & Birch & Beech & Oak & Ash & Lime & \\
\hline \multicolumn{8}{|l|}{ 1. Knots } \\
\hline \multirow{3}{*}{$\begin{array}{l}\text { Single knot } \\
\text { (DEB) }\end{array}$} & 3.3 & 3.4 & 0.5 & 0.8 & 1.4 & 3.3 & Knot/meter \\
\hline & 80 & 96 & 54 & 50 & 60 & 98 & Lamellas with knots (\%) \\
\hline & 0.08 & 0.09 & 0.31 & 0.16 & 0.09 & 0.17 & $\emptyset$ DEB size \\
\hline \multirow{2}{*}{$\begin{array}{l}\text { Knot cluster } \\
\text { (DAB) }\end{array}$} & 49 & 47 & 7 & 17 & 20 & 50 & Lamellas with DAB > DEB (\%) \\
\hline & 4 & 6 & 0 & 2 & 2 & 11 & $\begin{array}{l}\text { Lamellas, where DAB sorting } \\
\text { class relevant }(\%)\end{array}$ \\
\hline $\begin{array}{l}\text { Knot } \\
\text { boundaries }\end{array}$ & $\begin{array}{l}\text { Often not } \\
\text { clear }\end{array}$ & $\begin{array}{l}\text { Often not } \\
\text { clear }\end{array}$ & $\begin{array}{l}\text { Sometimes } \\
\text { not clear }\end{array}$ & Clear & $\begin{array}{l}\text { Often not } \\
\text { clear }\end{array}$ & $\begin{array}{c}\text { Often not } \\
\text { clear with } \\
\text { inbark }\end{array}$ & \\
\hline 2. Slope of grain & \multicolumn{7}{|c|}{ Visual determination questionable } \\
\hline 3. Pith & 19 & 15 & 2 & 2 & 18 & 0 & Lamellas with pith $(\%)$ \\
\hline 4. Annual ring width & 99 & 22 & 96 & 100 & 100 & 98 & Determination possible (\%) \\
\hline \multicolumn{8}{|l|}{ 5. Shake/Crack } \\
\hline Shrinkage crack & 14 & 6 & 28 & 45 & 31 & 0 & Lamellas with cracks (\%) \\
\hline $\begin{array}{l}\text { Frost crack, } \\
\text { ring shake }\end{array}$ & \multicolumn{6}{|c|}{ Not apparent } & \\
\hline 6. Wane & \multicolumn{6}{|c|}{ Sorted out } & \\
\hline 7. Warp & \multicolumn{6}{|c|}{ Only minor due to trimming } & \\
\hline 8. Stains, rot & 2 & 0 & 24 & 0 & 0 & 0 & Lamellas with stains, rot (\%) \\
\hline 9. Worm holes & \multicolumn{6}{|c|}{ Sorted out prior to planning } & \\
\hline \multicolumn{8}{|c|}{ 10. Other characteristics } \\
\hline Inbark & Below 5 & Below 10 & 44 & Below 10 & Below 10 & abundant & Lamellas with inbark $(\%)$ \\
\hline Heartwood colouring & 35 & 34 & 0 & 0 & 70 & 0 & Lamellas with heartwood colouring (\%) \\
\hline
\end{tabular}

Maple, birch and lime lamellas exhibit the highest number of single knots per meter (3.3 to 3.4). Beech shows the biggest single knots (DEB) with a mean DEB value over all investigated knots of 0.31 . Oak and lime knots have twice the size of maple, birch and ash knots (mean DEB). Knot clusters are abundant in maple, birch and lime (see Tab. 2a). These clusters are often accompanied by veined wood tissue (i. e. curly or wavy wood; see Tab. 2e). In the lime collective, knot clusters are sorting class relevant in $11 \%$ of the lamellas. For the other species, they are of minor influence on the visual sorting according to DIN 4074-5 (2008). This confirms the findings made by other authors for medium-dense European hardwood species. For beech, three studies prove that the criterion $\mathrm{DAB}$ is not sorting class determining (Blaß et al., 2005; Frese and Riedler, 2010; Glos and Lederer, 2000). In Schlotzhauer et al. (2018b) out of 324 sorted maple lamellas and 220 sorted ash lamellas only $3.7 \%$ and $1.4 \%$ of the lamellas were downgraded due to the sorting criterion DAB. A critical aspect in the visual characterization of hardwood lamellas is the determination of knot boundaries respectively exact knot sizes (see as example maple in Tab. 2e). Especially in maple, birch and ash, knot colour and the colour of the surrounding wood tissue is very similar. Birch knots are dark in the centre (Tab. 2d). Here the colour change within a knot can accidently be interpreted as knot boundary as well. Thus, the knot size is underestimated. Ash knots often show holes in their centre. These holes also appear in lime together with abundant bark ingrowth (inbark) in and around knots (see Tab. 2b). This makes knot size determination difficult. Beech knot boundaries are mostly clear, unless staining and/or rot appears in (and also around) knots, for which beech is susceptible. One quarter of the 46 investigated lamellas comprised knots with beginning white rot or staining (see Tab. 2f).

Comparing the knot size results of two different graders (A and B) for a subset of randomly selected lamellas reveals the weaknesses of the visual grading system (see Fig. 7). For beech, oak, ash and lime the two grading repetitions (grader A and B) lead two a differing sorting class distribution.

Sorting class differences between the two graders are most substantial for lime, for which knot boundaries are unclear. For ash and birch, grading results are identical, although knot size determination is evaluated to be very difficult. Especially 


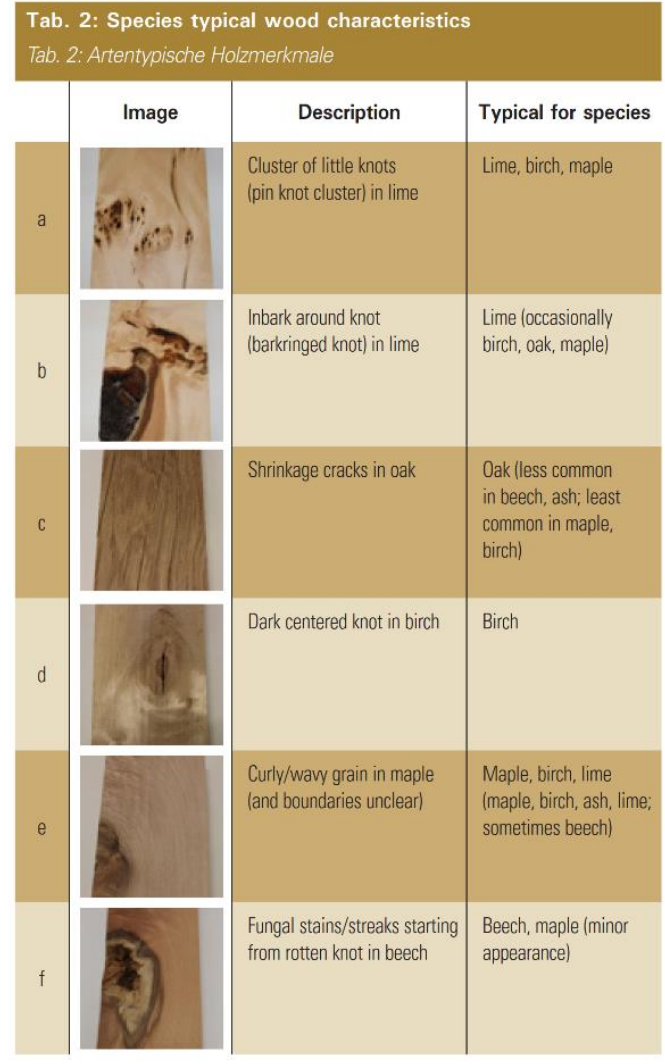

on oak, knot boundaries are evaluated to be clear. Nonetheless, grading results are different for the two different graders (see Fig. 7). To avoid grading inaccuracies owed to visual determination, opto-sensory systems for automatic knot evaluation need to be developed for the application on hardwoods. For softwoods, these systems are on the market (Microtec, WoodEye, ATB Blank etc.).

The annual ring width is a further visual sorting criterion. For hardwoods, though, no boundary values are set in DIN 4074-5 (2008). Fig. 8 plots the measured values, which especially for maple and lime vary greatly.

On the majority of the birch lamellas (78 \%), the annual ring width was not recognizable. Although, for maple it was recognizable, it was often difficult to determine due to little colour differences between earlywood and latewood. Sometimes, this was also the case for lime and beech. A very sharp crosscut saw blade leads to best recognisability. Also wetting the crosscut (end-grain) surface, leads to better recognisability. The ring-porous species ash and oak are not problematic. Due to the shortcoming of the method and the high variability of the annual ring width even within one lamella, this sorting criterion is not applicable on most of the hardwoods. The machine sorting criterion density represents a viable alternative,

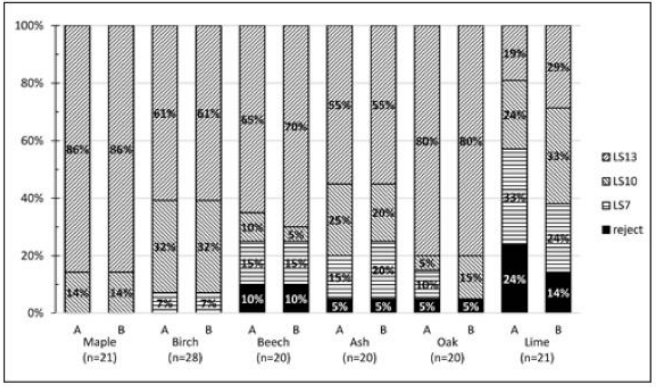

Fig. 7:Visual sorting class (according to DIN 4074-5, 2008) assignments after DEB size - class distribution difference between two different graders (A and $B$ )

$A b b$. 7: Sortierergebnis der visuellen Festigkeitssortierung (gemäß DIN 4074-5, 2008) nach DEB - Sortierunterschiede zwischen zwei Sortierpersonen (A und $B$ )

for which strength-density-correlations of up to $0.6\left(\mathrm{R}^{2}\right)$ for softwoods have been proven (Glos, 1995).

Shrinkage cracks are allowed in all DIN 4074-5 (2008) sorting classes. Shrinkage cracks affect the perpendicular to grain tension strength (Schlotzhauer et al., 2018a). They occurred in $50 \%$ of the oak lamellas (see Tab. 2c). Ash and beech lamellas are also susceptible to cracking, especially around knots. No shrinkage cracks were found in the investigated lime. Wane, warp, stains (and rot) and worm holes were (mostly) not apparent in the sorted wood (see Tab. 1 sorting criteria 6-10). This is an effect of pre-sorting before planing. Therefore, this result is not representative. Investigations on large volumes of sawn timber need to be carried out to find representative distributions of the occurrence of certain characteristics. For the occurrence of wane and warp, tree quality and wood drying quality as well as the selected oversize are important factors. In the selected wood species, staining and rot was mostly observed in beech, where these characteristics typically start at broken off branches (knots). In maple, staining and rot was also witnessed. In lime, already a slight raise in the relative humidity leads to mould formation on the wood surface. In lime, inbark occurred very frequent (see Tab. 2b), especially around knots. In oak, birch and maple only a few lamellas showed inbark (5-10\%). Inbark dimensions are hard to quantify. In combination with knots (i. e. lime), knot size determination is also hindered. Heartwood colouring is abundant in ash (70\%), while about one third of the birch and maple lamellas were characterized by heartwood colouring. Although it is known that beech also forms facultative heartwood colouring, the investigated collective did not show the characteristic. The probability of the formation of the so-called "red heart" in beech rises drastically at the age of 120 years respectively approximately $60 \mathrm{~cm}$ diameter (Weller, 2016). The investigated beech collective originated from trees that had diameters of maximum $40 \mathrm{~cm}$. In oak, actually all lamellas comprised only heartwood (not facultative), since production process removes the little proportion of minor quality sapwood. Nonetheless, the lamel- 


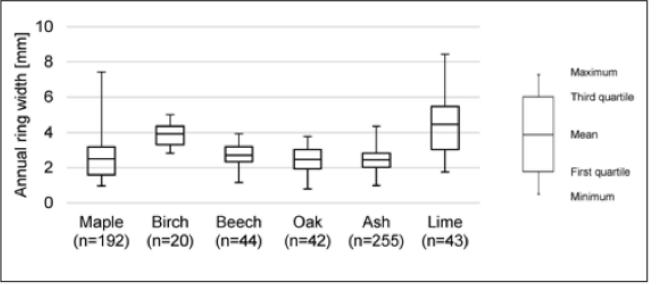

Fig. 8: Annual ring width $(\mathrm{mm})$ separated after wood species Abb. 8: Jahrringbreite $(\mathrm{mm})$ unterteilt nach Holzarten

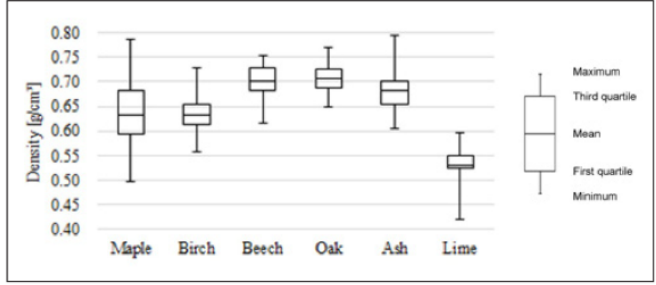

Fig. 10: Lamella densities $\left(\mathrm{g} / \mathrm{cm}^{3}\right)$ separated after wood species Abb. 10: Lamellen-Rohdichten $\left(\mathrm{g} / \mathrm{cm}^{3}\right)$ unterteilt nach Holzarten las are evaluated as free of heartwood colouring, since no colour changes are visible within the single lamellas. Heartwood colouring can be interesting for aesthetic reasons, i. e. indoor applications of building products, where the appearance might play an important role.

\section{Machine sorting}

$\mathrm{MOE}_{\mathrm{dyn}}$ is widely used in softwood grading systems. The determination procedure is the same for hardwoods as for softwoods. Fig. 9 plots the Timbergrader MTG measurement results for the six selected hardwoods.

The values vary greatly. Especially for the species maple, ash and lime. Mean values are the lowest for lime $\left(10,502 \mathrm{~N} / \mathrm{mm}^{2}\right)$ and the highest for ash with $15,050 \mathrm{~N} / \mathrm{mm}^{2}$. For some lamellas, the Timbergrader MTG did not give results (compare $\mathrm{n}$ in Fig. 5 and Fig. 9). The 34 maple lamellas, for which no $\mathrm{MOE}_{\mathrm{dyn}}$ was recorded, were all very short (mostly below $1 \mathrm{~m}$ length). The shorter the lamella gets, the harder it gets to produce a longitudinal oscillation, which is not superimposed by other oscillations (e. g. transverse). This is also the case for 14 ash lamellas and two lime lamellas. The Timbergrader MTG was also not able to deliver $\mathrm{MOE}_{\mathrm{dyn}}$ values for two beech lamellas and two lime lamellas, which exhibited very big knots (DEB and DAB around 1). With the alternative measurement system Grindosonic, it was possible to calculate $\mathrm{MOE}_{\mathrm{dyn}}$ values for these lamellas, although in most cases the values are to be questioned. For the mentioned lamellas, measurement repetitions produced values that varied greatly and were in

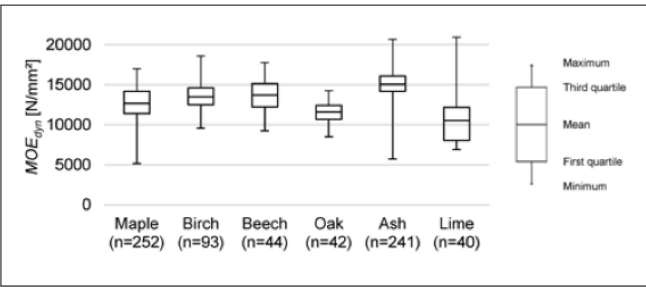

Fig. 9: $M_{\text {dyn }}$ determined with the Timbergrader MTG system separated after wood species

Abb. 9: $M O E_{d y n}$-Werte ermittelt mit Timbergrader MTG unterteilt nach Holzarten most cases extreme (as low as $1,000 \mathrm{~N} / \mathrm{mm}^{2}$ and as high as $40,000 \mathrm{~N} / \mathrm{mm}^{2}$ ).

The density measurement results are plotted in Fig. 10.

Lime exhibited the lowest mean density $\left(0.53 \mathrm{~g} / \mathrm{cm}^{3}\right)$, oak and beech the highest $\left(0.71 \mathrm{~g} / \mathrm{cm}^{3}\right.$ and $\left.0.70 \mathrm{~g} / \mathrm{cm}^{3}\right)$. Values varied greatly within one species group-most for maple, lime and ash.

\section{Summary}

The questions formulated in the introduction section can be answered as follows:

(1) When using market available, low to medium quality sawn hardwood timber assortments, what is the quality yield (concerning strength grading)?

The tested lime collective shows the worst lamella quality. $34 \%$ of the lamellas are rejected, the other lamellas are equally distributed into the three visual strength grading classes. The oak collective comprises the least "rejects" and a high number of LS13 lamellas (69\%). Of the other examined hardwood species between $17 \%$ (birch) and $21 \%$ (maple) of the lamellas fall into the category "reject". Maple, ash and oak collectives show the highest lamella quality (LS10 and LS13). When excluding the sorting criterion pith from visual sorting according to DIN 4074-5 (2008), "reject" percentages of the maple, birch and ash collectives fall to $2-3 \%$. The beech, oak and lime collectives are not affected by this change. When allowing pith boards as load bearing elements in order to raise the material yield, the end use needs to be defined.

(2) Are all visual sorting parameters named by the $D I N$ 4074-5 (2008) clearly attainable/determinable for the selected hardwoods?

Most of the visual sorting parameters are attainable for the selected hardwoods. The determination of the annual ring width is in most cases not possible on birch lamellas and is often problematic on maple, beech and lime. Maple, birch, ash and lime knots often show unclear boundaries, what leads to different $\mathrm{DEB}$ and DAB values, when different graders sort lamellas. Also inbark is a parameter, whose size determination is in most cases problematic. Inbark occurs frequently in lime and sporadically in oak, birch and maple. A reliable visual slope of grain determination is not possible.

(3) Do the different hardwood species show specific and/ or typical characteristics respectively characteristics distributions? 
Typically, the species maple, birch and ash show little knots (mean DEB 0.08-0.09), while oak and lime knots have twice the size $(0.16-0.17)$ and beech knots over three times the size (0.31). The most knots per meter are found in ash, birch and lime (3.3-3.4). The least are found in beech and oak. A typical knot distance in the longitudinal direction is not observed for the investigated species. The occurrence of knot clusters is distinctive for maple, birch and lime. Often, around these clusters, curly wood tissue is found. In lime, also inbark occurs frequently. Oak is very susceptible to shrinkage cracks (45\% of lamellas), in beech and ash they occur in about one third of the lamellas ( $28 \%$ and $31 \%$ ). $70 \%$ of the investigated ash lamellas were characterized by the facultative heartwood colouring, while only about one third of the maple and birch lamellas contain coloured heartwood. In these species heartwood colouring is also a facultative characteristic as well as in beech. In the lower diameter beech logs selected for this study, heartwood colouring is not typical, though.

The characteristics distribution depends highly on the sourced raw material. Therefore, presented species-specific figure can only serve as a trend. Similar investigations need to be carried out for construction material assortments, when they are available. At present, this is not the case.

\section{Conclusion}

Yield wise, of the investigated collectives the species ash, maple and oak seem best suited for an application in load-bearing applications. They show the highest proportion of very good quality boards (LS13), i. e. low number of big knots and pith. Excluding the criterion pith from sorting raises ash and maple yield values even further and also points birch out to be interesting, when it comes to visual grading yield. Beech and lime shows very big knots. In lime, also inbark is abundant, for which sizes are very difficult to determine. Further research needs to evaluate the strength profiles of defined collectives of these species and especially the influence pith has on them.

\section{References}

Aicher S (2014) Laubholzprodukte und -anwendungen im Bauwesen - Aktueller Stand in Europa (Hardwood construction products and applications - the situation in Europe today). In: Proceedings of 20. International Wood Construction Conference, IHF 2014, Garmisch-Partenkirchen, Germany

Blaß HJ, Denzler J, Frese M, Glos P, Linsenmann P (2005) Biegefestigkeit von Brettschichtholz aus Buche (Bending strength of beech glulam). Karlsruher Berichte zum Ingenieurholzbau, Band I, Universitätsverlag Karlsruhe

DIN 4074-5 (2008) Strength grading of wood - Part 5: Sawn hardwood

DIN 52182 (1976) Testing of wood-determination of density

Ehlebracht V (2000) Untersuchung zur verbesserten Wertschöpfung bei der Schnittholzerzeugung aus schwachem Buchenstamm- holz (Fagus sylvatica L.) (Investigation on improved added value in the production of sawn lumber from low dimension beech timber). Dissertation, Georg August University Göttingen

EN 1310 (1997) Round and sawn timber-Method of measurement of features

EN 1912 (2013) Structural timber - Strength classes - Assignment of visual grades and species.

EN 13183-3 (2005) Moisture content of a piece of sawn timberPart 3: Estimation by capacitance method

Federal Ministry of Food and Agriculture (2014) Der Wald in Deutschland - Ausgewählte Ergebnisse der dritten Bundeswaldinventur (The forest in Germany-Selected results of the Third National Forest Inventory). Bundesministerium für Ernährung und Landwirtschaft (BMEL)

Frese M, Riedler T (2010) Untersuchung von Buchenschnittholz (Fagus sylvatica L.) hinsichtlich der Eignung für Brettschichtholz (Examination of suitability of beech lumber for glulam). Eur. J. Wood Wood Prod. 68: 445-453

Glos P (1995) Festigkeitssortierung (Strength grading). In: Blaß HJ, Görlacher R, Steck G (eds) Informationsdienst Holz - Holzbauwerke nach Eurocode 5. - Step 1: Bemessung BaustoffeStep 2: Bauteile, Konstruktionen, Details - Step 3: Grundlagen, Entwicklungen, Ergänzungen - Step 4: Eurocode 5, Nationales Anwendungsdokument, Arbeitsgemeinschaft Holz e. V., Düsseldorf, $p 9$

Glos P, Lederer B (2000) Sortierung von Buchen- und Eichenschnittholz nach der Tragfähigkeit und Bestimmung der zugehörigen Festigkeits-und Steifigkeitskennwerte (Strength grading of beech and oak lumber and determination of characteristic strength and stiffness values). Final report, Technical University of Munich

Glos P, Näher T (2005) Aufnahme der einheimischen Holzarten Buche (Fagus sylvatica), Eiche (Quercus petraea, Quercus robur) und Douglasie (Pseudotsuga menziesii) in die europäische Norm EN 1912 (Inclusion of the native wood species beech, oak and Douglas fir in the European standard EN 1912). Holzforschung München, Technical University of Munich

Glos P, Torno S (2008) Aufnahme der einheimischen Holzarten Ahorn, Esche und Pappel in die europäische Norm EN 1912 „, Bauholz - Festigkeitsklassen - Zuordnung von visuellen Sortierklassen und Holzarten " (Inclusion of the native wood species maple, ash and poplar in the European standard EN 1912 "Structural timber - Strength classes - Assignment of visual grades and species"). Final report No. 06517, Technical University of Munich

Görlacher R (1990) Klassifizierung von Brettschichtholzlamellen durch Messung von Longitudinalschwingungen (Classification of glulam lamellas via measurement of longitudinal oscillation). Report (4-21), University of Karlsruhe 


\section{ABSTRACT}

Charakterisierung von sechs europäischen Laubhölzern mittels visueller und maschineller Festigkeitssortierung

Um die Nutzung heimischer Laubhölzer als tragende Elemente in konstruktiven Holzbau zu steigern, ist es notwendig, deren Eignung auf technologischer und wirtschaftlicher Basis zu bewerten. Diese Veröffentlichung gibt Auskunft über die Festigkeitseigenschaften von sechs europäischen Laubholzarten. Marktverfügbare Schnittholzsortimente wurden als Forschungsmaterial ausgewählt. An Lamellen mit einem Querschnitt von $100 \times 30 \mathrm{~mm}^{2}$ und Längen bis zu drei Metern wurden Holzmerkmale visuell nach DIN 4074-5 (2008) aufgenommen. Zusätzlich wurden der dynamische Elastizitätsmodul $\left(M O E_{d y n}\right)$ und die Dichte bestimmt. Von den untersuchten Kollektiven wiesen die Kollektive der Holzarten Esche, Ahorn und Eiche die besten Lamellenqualitäten auf. Die Buchen- und Lindenkollektive waren durch viele große Äste gekennzeichnet, die zu häufigen Einstufung in untere Sortierklassen führten. Eine Vielzahl von Lindenlamellen zeigte Rindeneinwüchse, was sie für eine Anwendung im Bau weniger geeignet macht. In den Kollektiven Ahorn, Birke und Esche war die Markröhre das Hauptausschlusskriterium bei der Sortierung gemäß DIN 4074-5 (2008). Den Einfluss der Markröhre auf die mechanischen Eigenschaften gilt es zu untersuchen, um diese Lamellen eventuell für eine konstruktive Anwendung nutzbar zu machen. Esche weist die höchsten $M O E_{d y n}$-Werte, aber auch die höchste Wertevariation auf.Die höchsten Dichten wurden in den Buchen-und Eichenkollektiven gemessen. Zurzeit bietet der Markt keine getrockneten Laubschnittholzsortimente für konstruktive Anwendungen an. Geeignete Sortimente könnten aus Rundholz stammen, das derzei zur Energiegewinnung, oder als Kuppelprodukte aus der Produktion hochwertiger Hauptprodukte genutzt wird.

Schlüsselwörter: DIN 4074-5 (2008), dynamischer E-Modul $M O E_{d y n}$, Dichte, europäische Laubhölzer, Äste, Markröhre

Grosser D (2002) Das Holz der Esche - Eigenschaften und Verwendung (Ash wood-Properties and use). In: Bayerische Landesanstalt für Wald und Forstwirtschaft (eds) Beiträge zur Esche - Proceedings of Fachtagung zum Baum des Jahres 2001, LWF-Wissen, No. 34, Freising, Germany

Grosser D (2006) Das Holz der Pappeln - Eigenschaften und Verwendung (Poplar wood - Properties and use). In: Bayerische Landesanstalt für Wald und Forstwirtschaft (eds) Beiträge zur Schwarzpappel-LWF-Wissen, No. 52, Freising, Germany

Hentschel F, Butter K (2014) Untersuchung zur visuellen und maschinellen Festigkeitssortierung von Laubholzlamellen für die Anwendung in homogenen Brettschichtholzträgern (Investigations on the visual and machine strength grading of hardwood lallellas for homogeneous glulam). Project report, Georg August University Göttingen
Kovryga A, Schlotzhauer P, Militz H, van de Kuilen J-W (2018) Visual and machine strength grading of European ash and maple. Submitted to Holzforschung

Lennartz MW, Jacob-Freitag S (2016) Neues Bauen mit HolzTypen und Konstruktionen (New building with wood - types and constructions). Birkhäuser Verlag GmbH, Basel

Mantau U, Döring P, Hiller D (2013) Holzeinsatz im Bauwesen Verwendungsstrukturen nach Gebäuden und Gewerken (Wood in construction - Structure of use seperated after buildings and building parts). In: Weimar H, Jochem D (eds) Holzverwendung Im Bauwesen - Eine Marktstudie Im Rahmen der ,Charta für Holz “. Johann Heinrich von Thünen Institute, Hamburg

RVR (2015) Rahmenvereinbarung für den Rohholzhandel in Deutschland (RVR) (Framework agreement on raw timber trade in Germany). Deutscher Forstwirtschaftsrat und Deutscher Holzwirtschaftsrat

Schlotzhauer P, Ehrmann A, Bollmus S, Militz H (2018a) Critical discussion of perpendicular to grain tension testing of construction timber-Case study on European hardwoods. Submitted to Wood Mater. Sci. Eng.

Schlotzhauer P, Kovryga A, van de Kuilen J-W, Militz H (2018b) Analysis of economic feasibility of ash and maple lamella production for glued laminated timber. Submitted to Holzforsch.

Schlotzhauer P, Wilhelms F, Lux C, Bollmus S (2018c) Comparison of three systems for automatic grain angle determination on European hardwood for construction use. Eur. J. Wood Wood Prod. 76 (3): $911-923$ (https://doi.org/10.1007/s00107-0181286-z)

Seintsch B, Weimar H (2012) Actual situation and future perspectives for supply and demand of hardwood in Germany. In: Nemeth R, Teischinger A (eds) Proceedings of the $5^{\text {th }}$ Conference on Hardwood Research and Utilisation in Europe 2012, Sopron, pp 301-312

Torno S, van de Kuilen J-W (2010) Esche für tragende Verwendungen - Festigkeitseigenschaften visuell sortierten Eschenholzes (Ash for load-bearing use-strength properties of visually graded ash lumber). LWF Aktuell 77: 18-19

Weimar H, Seintsch B (2012) Laubholz in Deutschland - Auf welchen Markt trifft das Potenzial? (Hardwoods in Germany - What is the market for the potential?). In: Proceedings of BMELV conference ,Stoffliche Nutzung von Laubholz-Herausforderung für eine zukunfisfähige Holzverwendung ", Würzburg, Germany, p 11

Weller A (2016) Vergleich von Buchen-Durchforstungskonzepten bezüglich des dimensions- und altersabhängigen Rotkernrisikos basierend auf simulierten Z-Baum-Durchmessern (Comparison of thinning regimes for common beech concerning to the dimension and age dependent risk of beech heart based on simulated future crop tree diameters). forstarchiv 87: 107-120 


\section{Authors}

M.Sc. Philipp Schlotzhauer, born in 1985, studied Forest Sciences and Forest Ecology at the Georg-August-Universität Göttingen with a focus on tropical and international forestry and wood science. He has been a research assistant in the Department of Wood Biology and Wood Products at the Georg-August-Universität Göttingen, Büsgenweg 4, D-37077 Göttingen, since 2012 and is currently working on his doctoral thesis on the strength grading and strength properties of indigenous hardwoods.

pschlot1@gwdg.de

Dr. Susanne Bollmus studied Wood Science in Hamburg. Since 2004 she has been research associate at the Department of Wood Biology and Wood Products of the Georg-August-Universität Göttingen. She received her doctorate in 2010 at the same University in Göttingen on „Biological and technological properties of beech wood after modification with 1,3-dimethylol-4,5-dihydroxyethyleneurea (DMDHEU)". Since 2012, she has also dealt with the topic of „hardwood use“ and led a junior research group on the topic ,Creating new markets and applications for native hardwoods using novel technologies". Her work focuses on wood preservation, wood modification and physical properties of solid wood.

Prof. Dr. Holger Militz, born in 1960, studied Wood Science in Hamburg. He then completed his doctorate at the Agricultural University of Wagengingen (Netherlands). From 1990 to 2000 Militz headed the wood research institute SHR in the Netherlands. Since 2000 he has been professor and head of the department ,Wood Biology and Wood Products " at the Georg-August-Universität Göttingen. His research interests include wood preservation, wood modification and wood degradation.

\section{Ganzheitliche Strategie fördert Bauen mit Holz}

Der DHWR veröffentlicht eine Analyse der Ziele, Maßnahmen und Erfolge der schwedischen Strategie zur Förderung der Holzverwendung im Bau seit 2004.

Das Dokument ist eine sinngemäße Übersetzung und $\mathrm{Zu}-$ sammenfassung der schwedischen Holzbaustrategie und der von der Regierung veröffentlichten Abschlussevaluation. Die statistischen Zahlen sind der benannten Veröffentlichung des Thünen-Instituts entnommen oder spiegeln die Prognose der Linköpings Universität wider.

„Ein zentrales Ziel der deutschen Holzwirtschaft ist die Verbesserung der Rahmenbedingungen für das Bauen mit Holz. Wir wollen dazu beitragen, dass der Anteil des Holzbaus in Deutschland bis zum Jahr 2025 deutlich steigt - nicht nur im mehrgeschossigen Hausbau, sondern auch bei Ein- und Zweifamilienhäusern und landwirtschaftlichen Nutzgebäuden", so der DHWR-Geschäftsführer und Vorsitzende der AG Bauen mit Holz der „Charta für Holz 2.0“ Dr. Denny Ohnesorge. „In der DHWR-Roadmap ,Holzwirtschaft 2025" haben wir dieses Ziel mit konkreten Empfehlungen für die Politik versehen. Hierbei lohnt sich ein Blick über den Tellerrand - zum Holzbaumusterland Schweden. Die vom DHWR jetzt veröffentlichte Analyse der dortigen, ganzheitlichen Regierungsstrategie zur Förderung der Holzverwendung kann als Vorbild und Anregung für die Bundesrepublik dienen. Sie soll unsere Branche sowie die politischen Akteure dabei unterstützen, geeignete Maßnahmen für die weitere Entwicklung des Holzbaus in Deutschland zu formulieren."

Zusammenfassung: Die schwedische Holzbaustrategie wurde 2002 ins Leben gerufen. Sie war bis 2008 befristet, jedoch laufen einige Maßnahmen weiter. Mittlerweile gibt es auf lokaler und kommunaler Ebene viele Projekte, die nun selbst den Holzbau fördern. Der Marktanteil von Holzbauwerken wurde bei neuen mehrgeschossigen Wohnungsbauten gegenüber dem
Jahr 2000 von $1 \%$ auf insgesamt $17 \%$ gesteigert. Hallenbauten nahmen von nur $5 \%$ auf ganze $40 \%$ Marktanteil beim Neubau zu. Die gesetzte Brückenquote wurde eingehalten und somit eine Steigerung von $22 \%$ zum Jahr 2000 erreicht. Auch bei Einfamilienhäusern wurde ein Anstieg von circa einem Drittel im Vergleich zu 2004 verzeichnet. Bei der Vorfertigung von Gebäuden wurde sogar eine Verdreifachung festgestellt. Seit 2009 bot die schwedische Forst- und Holzwirtschaft innerhalb der drei Jahre andauernden Initiative „Trästad“ (Holzstadt) Beratungen für Kommunen bezüglich eigener, regionaler Holzbaustrategien an. Mittlerweile sind solche regionalen Strategien zahlreich etabliert. Insgesamt nahmen zwölf Kommunen selbständig teil, wobei das Projekt allen Kommunen des Landes offenstand.

Im Wesentlichen ist Trästad 2012 eine Holzbaustrategie auf Kommunalebene, die Forschung, Wirtschaft, Planungs- und Staatsbehörden sowie die Kommunalverwaltung selbst mit einbezieht. Die Kommunen fokussieren selbst den Holzbau und treiben ihn voran.

Eine Prognose der Universität Linköping (Brege et al., 2017) geht von einer möglichen Holzbauquote von $50 \%$ bis 2025 bei Mehrfamilienhäusern und einem Gesamtanteil von 30-35 \% bei Bauwerken aus. Folgt man der Voraussage, könnten weitere 8.000 Arbeitsplätze entstehen und 6.000 Arbeitsplätze von der Stadt auf das Land verlagert werden. Bis 2025 werden schätzungsweise 700.000 neue Häuser aus Holz gebaut.

Die Broschüre kann unter: www.verband-crm.de/tmp_uploads/2018.08.15_Schwedische_Holzbaustrategie_und_Evaluation.pdf heruntergeladen werden.

Kontakt:

Deutscher Holzwirtschaftsrat e. V. (DHWR), Melanie Wollenweber,E-Mail:presse@dhwr.de,www.dhwr.de 


\section{Paper b}

Analysis of economic feasibility of ash and maple lamella production for glued laminated timber 
1 Article

\section{Analysis of economic feasibility of ash and maple} 3 lamella production for glued laminated timber

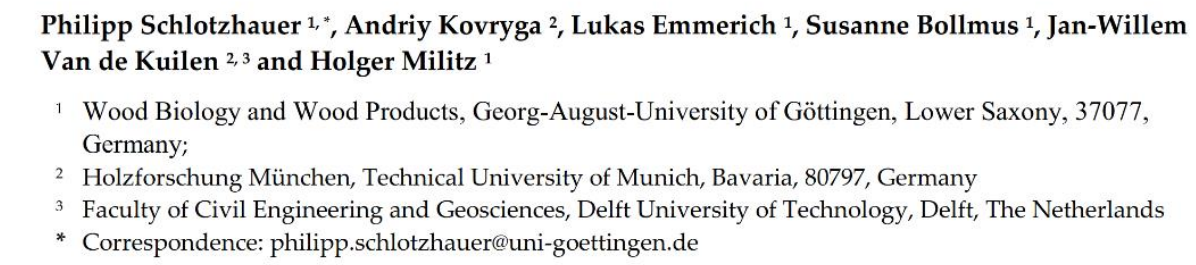

Abstract: Background and Objectives: In the near future, in Europe a raised availability of hardwoods is expected. One possible sales market is the building sector, where medium dense European hardwoods could be used as load bearing elements. For the hardwood species beech, oak and sweet chestnut technical building approvals already allow the production of hardwood glulam. For the species maple and ash this is not possible yet. This paper aims to evaluate the economic feasibility of glulam production from low dimension ash and maple timber from thinnings. Therefore, round wood qualities and the resulting lumber qualities are assessed and final as well as intermediate yields are calculated. Materials and Methods: 81 maple logs and 79 ash logs cut from trees from thinning operations in mixed (beech) forest stands were visually graded, cant sawn and turned into strength graded glulam lamellas. The volume yield of each production step was calculated. Results: The highest volume yield losses occur during milling of round wood (around $50 \%$ ) and "presorting \& planning" the dried lumber (56-60\%). Strength grading is another key process in the production process. When grading according to DIN 4074-5 (2008), another 40 - $50 \%$ volume loss is reported, while combined visual and machine grading only produces $7-15 \%$ rejects. Conclusions: Yield raise potentials were identified especially in the production steps milling, presorting \& planning and strength grading.

Keywords: Volume yield; European hardwoods; low quality round wood; strength grading; glulam

\section{Introduction}

The share of hardwoods in the wood stock of Central European forests is steadily increasing [1]. The higher availability of hardwoods requires the development of new markets and new value chains for an overall increase in use. A possible, large sales market is the application in load bearing structures.

Medium dense hardwoods have preferable mechanical properties compared to softwood. The higher tensile strength of hardwoods leads to either smaller member dimensions or higher load carrying capacities. The high bending strength for hardwood glulam (up to $48 \mathrm{MPa}$ ) has been reported by Blaß et al. [2] and Frühwald et al. [3] for beech glulam and by Van de Kuilen and Torno [4] for ash glulam. In recent years, a number of technical approvals for hardwood glulam have been issued:

- Beech glulam [5],

- VIGAM oak glulam [6],

- Schiller oak glulam [7], and 
- $\quad$ SIEROLAM glulam of chestnut [8].

Despite the attractive mechanical properties, the use of hardwoods in structural applications remains minor. According to Frühwald et al. [3] and Mack [9], more than $90 \%$ of the glulam products in Europe are made of softwood (mainly spruce). The survey by Ohnesorge et al. [10] on glulam producers in Germany, Switzerland and Austria revealed that in the year 2005 out of $900.000 \mathrm{~m}^{3}$ of glued rod-shaped solid wood products only $1 \%$ contained hardwood.

A number of technological reasons as well as historical and silvicultural reasons has led to the fact that mainly softwood is used in wood construction. The use of softwood has been favored over decades, because the physical properties are well predictable and differences between the different softwood species are small. Furthermore, softwood is characterized by long, straight logs with low degrees of taper, homogeneous assortments and little knots that are usually evenly distributed [11]. There are several further technological constraints for the use of hardwoods in structural applications, such as lack of knowledge of the long-term behavior of hardwood gluing, or the less number of certified grading machines compared to softwood, non-harmonized standardization and production processes not optimized for hardwood species.

One major aspect for the broader use of hardwoods in construction (especially glulam) is the economic feasibility of the production. For hardwoods, at present, no calculated data from a production facility is available. Torno et al. [12] estimated the production cost of ash lamellas to be three times higher as of spruce lamellas. Thus, besides the higher load bearing capacity of hardwood glulam, the cost-efficient use of the resource hardwood is required, in order to reduce this cost difference. This includes both the optimization of the production process and of the resources used. Processing cheap, particularly small diameter hardwood logs, which are usually used for energy recovery in Europe [12], is one of the frequently discussed issues. Exploiting small diameter hardwoods for material utilization, e.g. sawing, is an important issue in Northern America as well [13].

It is the aim of this paper to contribute to the overall goal of an effective use of the available hardwood resources by minimizing the waste of each production step (of glulam lamellas) separately and for the entire production. The use of small diameter logs from thinnings as poor-quality resource is in focus of this yield analysis. In the current study, the yield analysis from log sections to planed and graded glulam lamellas is performed using state of the art processing technology. Moreover, the achieved yields are linked to the mechanical properties relevant for glulam lamellas and measured for the investigated samples. Doing so, the economic feasibility of lamella production out of small diameter logs of the rare hardwood species maple and ash can be estimated. The single production steps and technologies of the production of glulam from low dimension maple and ash logs are analyzed and described.

\section{2. Conversion efficiency of hardwoods}

In literature, different terms exist to measure the conversion efficiency. In Northern America, the recovery rates with measures like lumber overrun, lumber recovery factor (LRF) and cubic lumber recovery (CLR) are used. In Europe, the term yield is most commonly used. All these definitions have in common that they calculate the volume ratio between the output sawn product and the input logs. The term yield goes even beyond that and can be determined for each production step separately. It can include final as well as intermediate products. This allows revealing and analyzing the weakest points of the production process. The use of waste material as side product or for energy production can also be considered. A higher lumber volume does not necessarily lead to higher lumber value. That is why it is important to distinguish between lumber volume recovery and lumber value recovery. For sawmill owners or managers, the latter is decision relevant [14].

Due to the low production volumes of hardwood glulam, yield values are known to only a very small extent. Studies on European hardwoods analyzing the yield from log to planed (dry-dressed) lumber are rare. Torno et al. [12] performed an extensive study on the production of beech lamellas and Van de Kuilen and Torno [15] on beech and ash lamellas. For lamellas sorted according to the German visual grading standard DIN 4074-5 [16], volume yield values as high as $26 \%$ for beech and 
$27.7 \%$ for ash were attained. When sorting the lamellas according to the more stringent sorting rules of the German technical approval Z 9.1679 [5], for the production of glulam the total yield starting at round wood (middle diameter classes $2 b-6$ ) ended at only $22 \%$ for beech and $26.9 \%$ for ash. In this case, however, higher mechanical properties are presumed. As shown by Torno et al. [12], the cutting pattern and the sawing technology affect the final yield. For graded beech lamellas those can drop to $10 \%$ or rise to $26 \%$. The highest yield was attained with the grade sawing method, where a vertical bandsaw headrig cuts "around the log" until only a heart plank is left. In these studies, in addition to the cutting pattern and the sawing technology, the quality and the diameter of the round wood had a major influence on the final yield. Frühwald et al. [3] estimate the total yield of the production of high-quality beech glulam from good to medium round wood qualities (B \& C) to be around 28.5 $\%$.

The reported final yields for hardwood lamellas are below the ones for softwoods. Final yields of the latter range from $24.5 \%$ to $38.5 \%$ [17,18]. Even higher yield values of $40 \%$ are stated by Torno et al. [12] for a modern spruce profiling unit. Frühwald et al. [3] mention that the final yield depends greatly on the size (production volume) of the glulam producing company. Only looking at the production of spruce glulam from dried sawn lumber, big producers are able to attain yields between $69 \%$ and $75 \%$, while little glulam producers only reach yields of $53 \%$.

Studies like the ones presented by Torno et al. [12] and Van de Kuilen and Torno [15] on the yield from logs to planed and strength graded hardwood lamellas are scarce. A few studies describe the yields of only individual production steps. Their results are summarized below.

\subsection{Sawing/Milling}

According to Steele [19], the following factors influence the lumber recovery in sawing (milling):

- Log diameter, length, taper, and quality

- Kerf width

- Sawing variation, rough green-lumber size, and size of dry-dressed lumber

- Product mix

- Decision making by sawmill personnel

- Condition and maintenance of mill equipment

- $\quad$ Sawing method

In the study of Lin et al. [14] in small US hardwood sawmills the factors log grade, diameter, sweep, length, species and sawmill specifications had a significant influence on the lumber volume recovery. It is also stressed that interactions between different factors can have a significant influence on the lumber volume recovery. Further influencing factors like board edging and trimming are also introduced. Richards et al. [20] simulate the volume and value yield of sawing hardwood lumber depending on the above mentioned factors. In their simulation the volume yield of live sawing is always higher than that of any 4-sided sawing pattern (quadrant, cant, and decision), when sawing the same size logs. When sawing small logs with large core defects the value yield, though, is higher when applying a 4-sided sawing pattern. The authors also emphasize the importance of the rotational position on the carriage for the first cut.

Ehlebracht [17] compares volume yield values of four German sawmills for the sawing of square-edged sawn lumber (rough green) from low dimension beech logs. The highest yield value of $57 \%$ is attained by a gang saw headrig utilizing the cant sawing method [20]. The lowest yield value of $36 \%$ is produced by a circular saw headrig, which produces a comparatively wide kerf. These values are consistent with the values reported by Emhardt and Pfingstag [21] and Fronius [22] that, when combining their findings, present values that range from $42 \%$ to $47 \%$ for the production of square-edged sawn lumber from low dimension beech logs (middle diameter classes $2 \mathrm{~b}$ and $3 \mathrm{a}$ ). The lower yield values of Ehlebracht [17] are comparable to the $35 \%$ yield reported by Fischer [23] for the production of parquet friezes and pallet boards from low dimension oak logs. For five small US hardwood mills, Lin et al. [14] report cubic recovery percentages (CRP) of $53.2 \%$ for red oak (Quercus rubra) and $57.5 \%$ for yellow polar (Liriodendron tulipifera). The CRP expresses the volume of rough green lumber as percentage of cubic log scale volume and is therefore comparable to the yield of the 
production step "sawing" analyzed by Ehlebracht [17]. The mean small-end diameter (SED) of the input logs in the study of Lin et al. [14] was $33 \mathrm{~cm}$, i.e. also low dimension logs were sawn. All five sawmills used the grade sawing method - two with circular saw headrigs and three with bandsaw headrigs. The simulations of Richards et al. [20] for US hardwood mills result in volume yield values, which range from $54 \%$ to $76 \%$. The high values, though, are only attainable, when live sawing large logs. According to Fronius [22], a further yield drop of $15 \%$ to $20 \%$ (relative to the original round wood volume) is to be expected, when square edging live sawn lumber.

\subsection{Drying}

Drying losses arise from volumetric shrinkage and the quality of the sawn lumber after drying. For hardwoods such as oak, improper drying results in staining, checking, splitting and warp, what leads to a reduced sawn wood value $[24,25]$. Therefore, proper drying schedules are of high importance.

Generally, the higher the specific gravity of the wood is the higher is also the volumetric shrinkage [26]. It varies within a species and even for lumber from the same log. The volumetric shrinkage during technical drying of rough green lumber to a moisture content of $12 \%$ ranges from $14 \%$ to $21 \%$ for beech, from $12.8 \%$ to $13.6 \%$ for ash and from $11.5 \%$ to $11.8 \%$ for maple $[17,27]$. Spruce shrinkage losses are around $12 \%$ [27]. The volumetric shrinkage in the production of hardwood lamellas for glulam lies between $11 \%$ and $17 \%$ for beech and at $9.8 \%$ for ash [15].

\subsection{Planing}

Planing losses depend on the chosen oversize, the final product and the drying quality (i.e. warping and bowing). The resulting losses present a combination of planing away the oversize and sorting out (presorting) boards with intensive bowing. For example, when trimming the lamellas to shorter lengths, the oversize can be reduced and thus the planing losses are also reduced. In similar studies to the presented one [12,15], planing and presorting losses (due to bowing) for the production of hardwood glulam lamellas vary from $18 \%$ to $46 \%$ - a relatively wide range.

\subsection{Grading}

Grading is an important step within the production, as the quality of sawn wood is assessed in terms of appearance (i.e. cladding, furniture) or mechanical properties predicted. As consequence, a discrete value is assigned to a lumber specimen. Both the quality of the produced lumber in terms of achieved mechanical properties and the yield are of interest. For grading, the yield is the share of drydressed lumber (dried, jointed and planed), which is assigned to a certain quality class and not rejected.

Data on hardwood grading yield in general, and on strength grading in particular, is scarce, since hardwoods are rarely strength graded. Generally, the yield losses depend on the grading method (machine vs. visual grading), wood quality, growth region, cross-section and sawing pattern selected. For European hardwoods, the effect the single mentioned factors have on the grading yield, are known to only a small extent. If lamellas are sawn pith free, the grading losses are lower compared to other sawing patterns. This is because the pith is a general rejection criterion for visually graded hardwood lumber after the German visual grading standard for structural timber DIN 4074-5 [16]. So, Glos and Torno [28] report for 324 ash boards and 459 maple boards graded according to DIN 4074-5 rules for joists rejection rates of as high as $21 \%$ and $37 \%$ due to pith and extreme grain deviation. It should be mentioned, though, that for that study the visual assessment of the boards is only being made for that part of each specimen, which is selected as free testing length. In Torno et al. [12] the loss values for beech lamellas range from $37 \%$ to $62 \%$, if graded visually in accordance with the German visual grading rules for structural lumber DIN 4074-5 [16]. If lamellas are graded in accordance with the German technical building approval for beech glulam Z 9.1679 [5] the rejection rate increases to $47 \%$ and $69 \%$. 


\section{Test material}

The round wood used for this investigation came from thinnings in mixed forest stands (mixed beech forests) of the state forestry offices Leinefelde and Heiligenstadt (Central Germany). The wood was harvested in the winter of 2014/2015 with harvester technology. Until the milling in June 2015, the round wood sections (logs) with a length between 3.20 and 3.40 m remained on the log yard of the department sawmill. According to the transport invoice $14.89 \mathrm{~m}^{3}(79 \mathrm{logs})$ of ash (Fraxinus excelsior L.) and $16.25 \mathrm{~m}^{3}$ (81 logs) of maple (80 logs of Acer platanoides L. and 1 log of Acer pseudoplatanus L.) were delivered (with bark). For the yield analysis, round wood sections (logs) with the following characteristics were ordered:

- $\quad$ round wood quality $C$ or worse (according to the Framework agreement on raw timber trade in Germany - RVR [29])

- $\quad$ length $\geq 3.20 \mathrm{~m}$

- $\quad$ round wood diameter classes $2-3$

\section{4. Production steps and determination of characteristics}

\subsection{Round wood sections (logs)}

On the log yard the round wood sections were trimmed uniformly to a length of $3.15 \mathrm{~m}$ in order to be able to determine the heartwood coloring (i.e. brown heart) on both ends. At the top (small) end of each trunk a slice of $1-2 \mathrm{~cm}$ thickness was cut off. The final cut was performed at the bottom of each trunk (large end) to a length of $3.15 \mathrm{~m}$. So, total $\log$ volumes were reduced to $14.3 \mathrm{~m}^{3}$ for ash and $15.8 \mathrm{~m}^{3}$ for maple. For each round wood section the minimum and the maximum diameter was determined in the middle of every $25 \mathrm{~cm}$ section. The last section only had a length of $15 \mathrm{~cm}$. Using the mean diameter for each $25 \mathrm{~cm}$ respectively $15 \mathrm{~cm}$ section $\left(\mathrm{d}_{M n}\right)$, the section volumes were calculated with Huber's formula. The single section's volumes were then added up resulting in equation (1).

$$
\mathrm{V}_{\mathrm{Sec} .}=\left(\sum_{1}^{12} \frac{\pi}{4} * 0,25 \mathrm{~m} * \mathrm{~d}_{M n}{ }^{2}\right)+\frac{\pi}{4} * 0,15 \mathrm{~m} * \mathrm{~d}_{M n}{ }^{2} \quad\left[\mathrm{~m}^{3}\right]
$$

219

The logs were sorted into diameter classes according to their small-end (top-end) diameter (SED) and into quality classes according to the specifications of the RVR [29] and DIN 1316-3 [30]. Both standards allow the assignment to classes from A (highest quality) to D (lowest quality). The qualitydetermining characteristics of the round wood sections were determined and recorded in accordance with Annex VIII (Measurement of the characteristics) of the RVR [29]. The characteristics shrinkage cracks, insect holes, tree cancer and the so-called moon ring (light discoloration in heartwood) were not recorded and thus were not part of sorting.

The RVR [29] offers no separate quality grading for maple and ash logs. Thus, depending on the particular characteristic, the oak grading rules (e.g. for knots, star shake, twigs, etc.) or those for beech (only for width of brown heart and heart shake) were used.

\subsection{Sawing/Milling}

The logs were milled with a mobile horizontal bandsaw headrig (Montana ME 90 2.0, SERRA) with a kerf width of $2.45 \mathrm{~mm}$. The cant sawing patterns used are shown in Figure 1. 
A

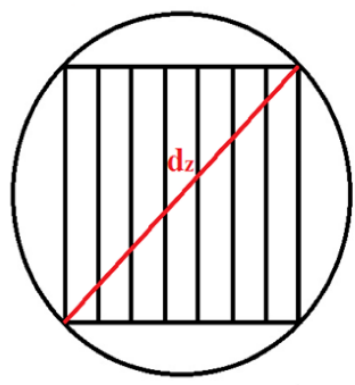

B

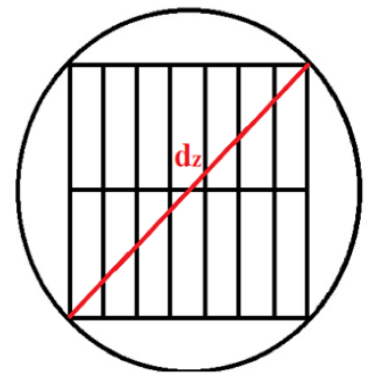

C

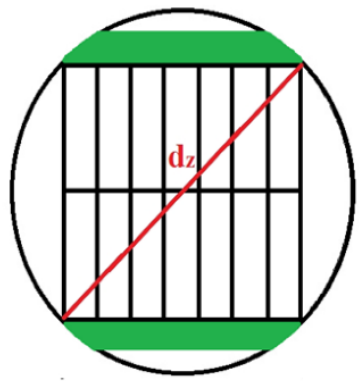

Figure 1. Cant sawing patterns of the milling.

The sawing patterns and the distribution of board dimensions were chosen for each log separately, mainly depending on the small-end log diameter ( $\mathrm{dz}$ or SED). Thus, the maximum yield could be attained. The pattern A was used most. If side boards were produced (colored boards in pattern C), they were edged to square edged lumber on a circular saw. For maple, five different lumber dimensions were sawn, for ash three (see Table 1).

Table 1. Nominal dimensions and quantities (n) of sawn green lumber and the resulting planed lamellas (dry-dressed lumber).

\begin{tabular}{cccc}
\hline $\begin{array}{c}\text { Sawn green } \\
\text { lumber }\end{array}$ & $\begin{array}{c}\text { Planed } \\
\text { lamellas }\end{array}$ & Maple & Ash \\
\hline $\begin{array}{c}\text { width } \times \text { height } \\
{[\mathrm{mm}] \times[\mathrm{mm}]}\end{array}$ & $\begin{array}{c}\text { width } \times \text { height } \\
{[\mathrm{mm}] \times[\mathrm{mm}]}\end{array}$ & $\mathrm{n}$ & $\mathrm{n}$ \\
\hline $\mathbf{1 1 5} \times \mathbf{3 5}$ & $\mathbf{1 0 0 \times \mathbf { 2 5 }}$ & 88 & - \\
$\mathbf{1 4 5} \times \mathbf{3 5}$ & $\mathbf{1 2 5} \times \mathbf{2 5}$ & 132 & - \\
$\mathbf{1 4 5} \times \mathbf{4 0}$ & $\mathbf{1 2 5} \times \mathbf{3 0}$ & 85 & 121 \\
$\mathbf{1 1 5} \times \mathbf{4 5}$ & $\mathbf{1 0 0} \times \mathbf{3 5}$ & 92 & 104 \\
$\mathbf{1 4 5} \times \mathbf{4 5}$ & $\mathbf{1 2 5} \times \mathbf{3 5}$ & 94 & 162 \\
\hline
\end{tabular}

Only the main product glulam lamella was produced for this study. No side products like trimming or baseboards (etc.) were produced. The side products would raise the final yield. The final product - planed glulam lamellas - were subjected to destructive tensile testing after visual and machine strength grading (see sub sample "TH II" in Kovryga et al. [31]).

\subsection{Drying}

The technical drying took place in the in-house conventional dryer (HB Drying Systems). The drying parameters were chosen in order to ensure gentle drying of the boards. The drying process took 21 days. To determine the volumetric shrinkage, the dry lumber volume (at $12 \%$ moisture content) is subtracted from the sawn lumber (rough green) volume. For this purpose, for each dimension and wood species six lamellas were selected randomly. On these lamellas, the lengths (in $\mathrm{mm}$ ) were determined with a tape measure on the rough green and the dry lumber. Lumber dimensions (in $\mathrm{mm}$ ) were measured at intervals of $25 \mathrm{~cm}$ - starting and ending at the board ends. 


\subsection{Presorting and planing}

The dried boards were jointed and planed to glulam lamellas (dry-dressed lumber) with the nominal dimensions presented in Table 1. After the planing process, each lamella that could not attain the nominal dimension (cross-section) on the full length was sorted out (due to a combination of bowing and too little oversize). The volume of the remaining glulam lamellas was calculated by determining their lengths with a tape measure and using the nominal lamella dimensions.

\subsection{Strength grading of planed boards}

\subsubsection{Visual strength grading}

To assess the quality of hardwood lamellas, different grading methods were used. First, each of the lamellas was visually classified according to the German visual strength grading standard DIN 4074-5 [16] over the entire length. The standard uses ten visual criteria to assign hardwood boards to visual strength grading classes. In the current study, the knottiness, presence of pith, bark inclusion, wane and fibre deviation (grain angle) were considered.

All relevant grading criteria were measured as defined in DIN 4074-5 [16]. To assess the knottiness - one of the major parameters of strength grading - the criteria Single Knot (SK) and Knot Cluster (KC) were used. Single Knot or DIN Einzelast Brett (DEB) relates the size of the single knot to the lamella width. For grading, the ratio (knot) with the highest value is indicative. Knot cluster $(\mathrm{KC})$ or DIN Astansammlung Brett (DAB) is a multiple knot criterion, which considers all knots appearing in a (moving) window of $150 \mathrm{~mm}$. Therefore, the spread of all knots over the $150 \mathrm{~mm}$ window is related to the width of the board. The edge knot criterion (E) or Schmalseitenast is an optional criterion for boards and represents the penetration depth of the knots appearing on the edge side only. A low value of these visual grading criteria stands for either rare occurrence or small size of the strength reducing knots and vice versa.

The only adjustment made concerns the measurement of the fibre deviation (grain angle). Fibre deviation is defined as an angle between the fibres and loading direction over a certain length and is measured in percent. The grain angle has a significant impact on strength [32]. Most grading standards indicate that the fibre deviation can be measured on drying checks or by the scribing method on the wood surface. Both methods are reported to have limited use for medium-dense hardwoods [33,34]. In the present study, the visible fibre deviation was detected on drying checks and, additionally, the surface was assessed qualitatively for fibre deviations exceeding the limits of DIN 40745 [16]. The specimens exceeding the limits are rejected.

Hardwood boards are assigned to the visual grades LS13 (highest quality), LS10 (medium quality) and LS7 (lowest quality) based on the boundary values listed in Table 2. To assign a lamella to a visual grade, all boundary values are to be met. Otherwise, the specimen is assigned to the next lower grade or rejected.

Table 2. Boundary values for grading of hardwood lamellas to visual grades (LS7 to LS13) after DIN 4074-5 [16].

\begin{tabular}{cccc}
\hline & LS13 & LS10 & LS7 \\
\hline DEB (SK) & 0.2 & 0.333 & 0.5 \\
DAB (KC) & 0.333 & 0.5 & 0.666 \\
Edge knot (E) & $-*$ & $-*$ & $-*$ \\
Pith & no & no & no \\
Fibre deviation & $7 \%$ & $12 \%$ & $16 \%$ \\
\hline *no requirements set & & &
\end{tabular}

Additionally, to estimate the effect of the grading parameters pith and DAB on the yield, two grading combinations - one without any requirements on pith and one without any requirements on pith and DAB - are applied to the lamellas. 


\subsubsection{Combined visual and machine strength grading}

Additionally, the boards were graded using a combined visual and machine grading approach. The procedure was suggested by Frese and Blaß [35] and is used for beech glulam produced after the German technical building approval Z-9.1-679 [5]. This grading approach combines visual grading parameters (i.e. SK and KC) with the dynamic Modulus of Elasticity (MOEdyn), a parameter used in most state of the art grading machines for softwoods. The MOEdyn was determined using the "Eigenfrequency" method (laboratory and grading machine ViSCAN by MiCROTEC). In case of ViSCAN, the natural frequency (f) from longitudinal oscillation was combined with the density ( $\mathrm{Q}$ ) measured by an x-ray source and the length (1) of the measured specimen (Eq. 2). In laboratory, the density was determined using the gravimetric method. Both measurements provide comparable results in terms of $R^{2}$ value (0.972).

$$
M O E_{d y n}=4 * l^{2} * \rho * f^{2} * 10^{6}
$$

The combined approach uses separate boundary values for visual grading parameters (i.e. SK, $\mathrm{KC})$ and MOEdyn. The boundaries presented by Frese and Blaß [35] are fitted to beech lamellas. For the present study, the combined grading is optimized for ash and maple and presented by the paper Kovryga et al. [31]. Table 3 shows the combination of boundary values selected for the current study. As example, for maple the "Solution B" and for ash the "Solution C" proposed for combined grading by Kovryga et al. [31] is selected. The presented combination allows grading to three different grades plus reject group. The highest grade shows characteristic tensile strength values (above $38 \mathrm{~N} / \mathrm{mm}^{2}$ ) fitting the tensile strength of finger jointed lamellas stated by Van de Kuilen and Torno [4].

Table 3. Optimized grading rules for combined visual and machine strength grading of ash and maple (according to Kovryga et al. [31]; maple: "Solution B", ash: "Solution C").

\begin{tabular}{|c|c|c|c|c|c|c|c|}
\hline & \multirow[b]{2}{*}{ Grade } & \multicolumn{5}{|c|}{ Boundary values } & \multirow{2}{*}{$\begin{array}{c}\text { resulting } \\
\text { Tensile- } \\
\text { Classes }\end{array}$} \\
\hline & & $\begin{array}{c}\text { DEB (SK) } \\
{[-]} \\
\end{array}$ & $\begin{array}{c}\text { DAB (KC) } \\
{[-]}\end{array}$ & $\begin{array}{c}\text { Edge knot (E) } \\
{[-]}\end{array}$ & $\begin{array}{c}\text { Pith } \\
{[-]}\end{array}$ & $\begin{array}{c}\text { MOEdyn }_{\text {dy }} \\
{\left[\mathrm{kN} / \mathrm{mm}^{2}\right]}\end{array}$ & \\
\hline \multirow{4}{*}{ Maple } & 1 & 0.1 & 0.1 & $-*$ & allowed & 13.9 & DT38 \\
\hline & 2 & 0.2 & 0.5 & $-*$ & allowed & 12.2 & DT25 \\
\hline & 3 & 0.3 & 0.6 & $-*$ & allowed & 10.9 & T15 \\
\hline & Reject & & & & & & \\
\hline \multirow{4}{*}{ Ash } & 1 & 0.2 & 0.2 & $-*$ & allowed & 16.5 & DT38 \\
\hline & 2 & 0.3 & 0.3 & $-*$ & allowed & 15.5 & DT34 \\
\hline & 3 & 0.4 & 0.4 & $-*$ & allowed & 11.6 & DT22 \\
\hline & Reject & & & & & & \\
\hline
\end{tabular}

*no requirements set

\subsection{Yield calculation}

For the determination of the total yield, the yields of each single production step are added up. The yield of each production step is calculated by dividing the output product volume by the input volume. How volumes of each intermediate product are calculated and what assumptions are made for these calculations, is described above for each production step separately. 


\section{Results and Discussion}

\subsection{Grading of logs}

Table 4 shows the sorting of the maple and ash logs into diameter and quality classes. Following the descriptions of Van de Kuilen and Torno [15], the diameter sorting was carried out by considering the small-end diameter (SED) inside bark. The supplied round wood sections mainly cover the diameter classes from $2 a$ to $3 b$, with individual sections with diameters below $20 \mathrm{~cm}$ and over $40 \mathrm{~cm}$. For maple and ash, the bark shows a mean thickness of $0.5 \mathrm{~cm}$. Maple shows a higher number of logs graded to the higher quality classes (B and C) compared to ash.

Table 4. Number of logs per species sorted after small-end diameter (inside bark) class and quality class according to RVR [29].

\begin{tabular}{|c|c|c|c|c|c|c|c|c|c|c|c|c|c|c|c|}
\hline \multirow{2}{*}{\multicolumn{2}{|c|}{$\begin{array}{l}\text { Diameter class } \\
\text { Quality class }\end{array}$}} & $2 a$ & $2 b$ & $3 b$ & 4 & $1 \mathrm{~b}$ & $2 a$ & $2 b$ & $3 a$ & $3 b$ & $1 \mathrm{~b}$ & $2 a$ & $2 b$ & $3 a$ & $3 b$ \\
\hline & & \multicolumn{4}{|c|}{ B } & \multicolumn{5}{|c|}{ C } & \multicolumn{5}{|c|}{ D } \\
\hline \multirow{2}{*}{ Quantity } & Maple & & 3 & 2 & 1 & 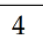 & 18 & 11 & 9 & 3 & 5 & 14 & 5 & 2 & 3 \\
\hline & Ash & 1 & & & & & 8 & 16 & 5 & 1 & 2 & 23 & 19 & 4 & \\
\hline
\end{tabular}

Table 5 and Table 6 show the results of the log quality sorting according to RVR [29] and DIN 13163 [30] in detail.

Table 5. Yields in \% for quality sorting of logs according to RVR [29] separated after sorting criteria (log characteristics).

\begin{tabular}{|c|c|c|c|c|c|c|c|c|}
\hline \multirow{2}{*}{ Log characteristics } & \multicolumn{4}{|c|}{ Maple } & \multicolumn{4}{|c|}{ Ash } \\
\hline & A & B & $\mathrm{C}$ & D & A & B & $\mathrm{C}$ & D \\
\hline Callused knot (bump) & 23 & 1 & 76 & & 46 & & 54 & \\
\hline Healthy knot & 63 & 29 & 9 & & 89 & 10 & 1 & \\
\hline Decayed knot & 63 & 31 & 5 & 1 & 89 & 6 & 5 & \\
\hline Twigs & 76 & 24 & & & 100 & & & \\
\hline Bump on group of broken of twigs & 95 & 1 & 4 & & 100 & & & \\
\hline Star shake/check & 60 & 29 & 11 & & 4 & 14 & 80 & 3 \\
\hline Heart shake/check & 33 & 61 & 5 & 1 & 81 & 15 & 1 & 3 \\
\hline Frost crack & 98 & & 3 & & 99 & & 1 & \\
\hline Ring shake & 98 & 3 & & & 99 & & 1 & \\
\hline Bow (Sweep and crook) & 48 & 14 & 6 & 33 & 38 & 1 & 5 & 56 \\
\hline Spiral (twisted) grain & 98 & & 3 & & 100 & & & \\
\hline Rot & 99 & & & 1 & 97 & & & 3 \\
\hline Log length & 99 & & 1 & & 96 & & 4 & \\
\hline Width of brown heart & 86 & 14 & & & 25 & 46 & 29 & \\
\hline Final quality class of logs & & 8 & 56 & 36 & & 1 & 38 & 61 \\
\hline
\end{tabular}


Table 6. Yields in \% for quality sorting of logs according to DIN 1316-3 [30] separated after sorting criteria

\begin{tabular}{|c|c|c|c|c|c|c|c|c|}
\hline \multirow{2}{*}{ Log characteristics } & \multicolumn{4}{|c|}{ Maple } & \multicolumn{4}{|c|}{ Ash } \\
\hline & $\mathbf{A}$ & B & $\mathrm{C}$ & D & A & B & $\mathrm{C}$ & D \\
\hline Length & 99 & & 1 & & 96 & & 4 & \\
\hline Mid-diameter & 14 & 11 & 70 & 5 & & 4 & $9^{*}$ & \\
\hline Callused knot (bump) & 25 & & 34 & 41 & 47 & & 42 & 11 \\
\hline Healthy knot & 95 & & 5 & & 91 & 3 & 6 & \\
\hline Decayed knot & 90 & & 8 & 3 & 96 & & 4 & \\
\hline Eccentricity of pith & 88 & 13 & & & 80 & 20 & & \\
\hline Star shake/check & 60 & & 5 & 35 & 4 & & & 96 \\
\hline Heart shake/check & 40 & 14 & 46 & & 87 & 4 & 9 & \\
\hline Brown heart & 66 & & 34 & & 38 & 25 & 37 & \\
\hline Bow (Sweep and crook) & 61 & 5 & 1 & 33 & 39 & 5 & & 56 \\
\hline Rot & 99 & & & 1 & 97 & & & 3 \\
\hline Final quality class of logs & 1 & 1 & 26 & 71 & & & 4 & 96 \\
\hline
\end{tabular}

The Tables 5 and 6 present the final assignment of the round wood sections into the quality classes (the last row of both tables) based on the individual class assignment for each sorting criterion. Each single criterion's influence on the grading can be seen as well as the total distribution of quality classes per species. For example, according to DIN 1316-3 [30] $71 \%$ of the maple logs are graded into the lowest quality class D (see Table 6). The final percentage value is a result of all wood characteristics combined. It can be seen that for maple the grading into the D class is mainly due to the characteristics callused knot, star shake and bow. When sorting according to RVR [29] specifications, mainly log bowing is decisive for sorting into class D (see Table 5). Especially in the second lowest grade $\mathrm{C}$, it is observable that the two different quality sorting schemes weigh the different characteristics differently, i.e. have different characteristic's boundary values for the same class. While grading into RVR class C of maple is mainly due to callused knots (76 \%), DIN 1316-3 [30] sorting into class $C$ is due to a number of characteristics (mid diameter, callused knots, heart shake, brown heart). Both grading schemes sort the majority of the studied logs into the classes $\mathrm{C}$ and D.

In general, the two sorting guidelines for round wood use different lists of characteristics. For example, Table 6 shows that in the case of sorting according to DIN 1316-3 [30] the criterion middiameter leads to a classification into quality class C for $70 \%$ of the maple logs and for $96 \%$ of the ash logs. Compared to that, the diameter of the logs is not relevant, when sorting according to RVR [29]. The possible advantage of the absence of log size criteria is that the actual visible log quality can be assessed and used to qualify the logs for the production in addition to the diameter.

Looking at Table 5 and 6, it also becomes obvious that - under the same storage conditions - ash logs tend to form more severe end cracks (star and heart shake) than maple. This cracking results in a serious deterioration of quality and leads to a reduced sawn lumber yield (mainly value yield). Thus, it is recommended to saw (mill) ash logs shortly after logging or adapt storage (e.g. water storage) to ensure the best possible lumber quality and highest yield. Short storage times respectively adjusted storage conditions are also advised for maple logs, since fungal discoloration starting from the log ends presents problems [27]. For an end use as construction material, though, these discolorations may be of low significance, since they do not affect the elasto-mechanic properties of the lumber. 


\subsection{Yields from logs to unsorted glulam lamellas}

Table 7 summarizes the volume losses and the resulting yields for each production step. It can be seen that the major production losses arise from sawing the logs and presorting the dried boards. Both species do not differ considerably.

Table 7: Yield for each production step from logs to planed lamellas (unsorted).

\begin{tabular}{|c|c|c|c|c|c|c|c|c|c|}
\hline \multirow{3}{*}{ Product } & \multirow{3}{*}{ Production step (PS) } & \multicolumn{4}{|c|}{ Maple } & \multicolumn{4}{|c|}{ Ash } \\
\hline & & \multicolumn{2}{|c|}{ Yield } & \multicolumn{2}{|c|}{ Waste/Loss } & \multicolumn{2}{|c|}{ Yield } & \multicolumn{2}{|c|}{ Waste/Loss } \\
\hline & & in $\mathrm{m}^{3}$ & in $\%$ & in $\mathrm{m}^{3}$ & in $\%$ PS & in $\mathrm{m}^{3}$ & in $\%$ & in $\mathrm{m}^{3}$ & in $\%$ PS \\
\hline \multirow[t]{2}{*}{ Logs } & & 15.8 & & & & 14.3 & & & \\
\hline & Milling/sawing & & & 7.6 & 48.2 & & & 7.1 & 49.5 \\
\hline \multirow[t]{2}{*}{ Boards (green) } & & 8.2 & 51.8 & & & 7.2 & 50.5 & & \\
\hline & Drying & & & 0.7 & 8.7 & & & 0.8 & 10.7 \\
\hline \multirow[t]{2}{*}{ Boards (dry) } & & 7.5 & 47.3 & & & 6.5 & 45.1 & & \\
\hline & Presorting \& planing & & & 4.2 & 56.3 & & & 3.8 & 59.6 \\
\hline \multicolumn{10}{|l|}{ Planed } \\
\hline lamellas & & 3.3 & 20.9 & & & 2.6 & 18.2 & & \\
\hline
\end{tabular}

382

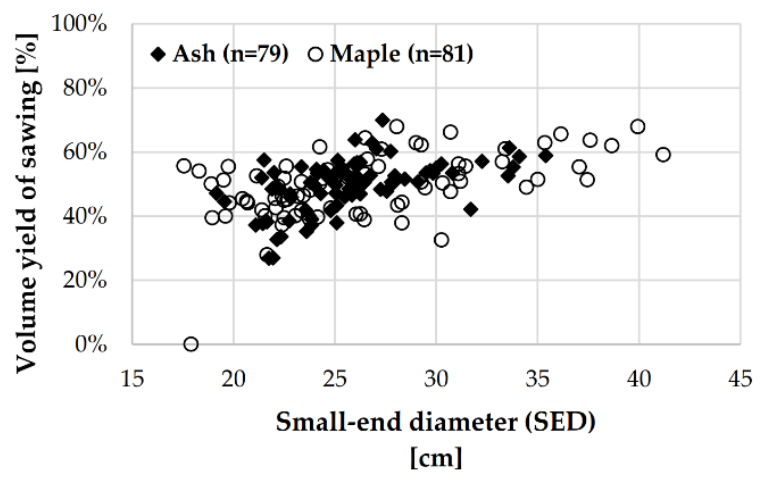

Figure 2: Volume yield of sawing ash and maple depending on the small-end log diameter (inside bark).

\subsubsection{Sawing/Milling}

The mean volume yield of sawing the 81 maple logs by the cant sawing method to square-edged lumber is $51.8 \%$. The mean volume yield of sawing the 79 ash logs is with $50.5 \%$ slightly lower. The $\log$ diameter strongly influences the volume yield of this production step. The effect the mid-diameter has on the sawing yield of this study can be observed in Figure 2.

The higher the log diameter gets, the higher the yield gets. The variation in sawing yield values drops with increasing diameters, as the influence of the log grade (quality class) on the yield decreases. Compared to the log diameter, the quality class only has a minor influence. Wade et al. [36] analyze data from 35 US hardwood mills and also conclude a positive linear relationship between 
$\log$ diameter and sawing yield (in their case LRF). In the simulation of Richards et al. [20] hardwood sawing yields of sawing low dimension logs $(S E D=25 \mathrm{~cm})$ by the cant sawing method start at 56.1 $\%$, while from logs with large diameters $(\mathrm{SED}=71 \mathrm{~cm}$ ) up to $67.2 \%$ rough green lumber can be produced. In Ehlebracht [17] only one of four hardwood mills attains a sawing yield of $57 \%$, when cant sawing low dimensional hardwood logs. Two mills achieve yields like this study (50\% and 51 $\%$ ), while a mill with a circular saw headrig only reaches $36 \%$ volume yield. All presented studies show that it is economically advantageous to sort out logs with diameters below a certain value. The boundary value for the diameter has to be determined for each production site and product separately. The results of Wiedenbeck et al. [13] give rise to the assumption that this boundary value also depends on the wood species sawn.

Lin et al. [14] prove that the log grade (quality class) has an effect on the hardwood volume recovery. In this study, this is only observed in the lower log diameter classes. The individual characteristics eccentricity of pith, ovality and taper show no significant influence on the yield of the first production step. The two latter characteristics are not part of the RVR [29] and DIN 1316-3 [30] sorting standards. Nonetheless, their influence on the yield during production is examined. For ash, the degree of bowing (in one direction) has no influence on the yield of milling. For maple, increased bowing (in one direction) leads to a decreased yield of milling. Multiple bows in one log (in one or more directions) decrease the yield of milling significantly. Comparing logs with one bow in only one direction with logs with multiple bows, the yield is reduced from $52.7 \%$ to $43.7 \%$ for maple and from $51.7 \%$ to $46.1 \%$ for ash. The same relationship - but less pronounced - can be found in so-called butt-cuts. In these first logs of trees taken above the stump, the milling process removes a high volume of wood from the large end of the log.

\subsubsection{Drying}

Drying of the green lumber was carried out for all dimensions and species with the same slow drying program, in order to avoid damages due to inadequate (i.e. too fast) drying. For maple, the volumetric shrinkage lies between $8.0 \%$ and $8.9 \%$ (average $8.7 \%$ ), while for ash it lies between 9.6 $\%$ and $11 \%$ (average $10.7 \%$ ). For both species, these values lie in the lower range of the abovementioned literature values. In some cases, the boards started warping (bowing, crooking, cupping, twisting, etc.) immediately after or even during the milling due to inherent tension in the trunks (eccentric pith, reaction wood, around big knots etc.). Nonetheless, these boards were stacked and underwent drying.

\subsubsection{Presorting and planing}

Before planing the dried boards, they were pre-sorted. Boards with extreme bowing were sorted out. If the infeed and outfeed rollers of the planer were able to press down the bow, resulting in fully planed board surfaces, the lamellas were not sorted out. Nevertheless, the volume loss of this production step is $56.3 \%$ for maple and $59.6 \%$ for ash. The resulting total yields of planed boards (unsorted glulam lamellas) are thus $20.9 \%$ for maple and $18.2 \%$ for ash. If the presorting was excluded from this calculation, i.e. if the bows were cut out (resulting in shorter lamella lengths) and thus all boards could be planed to the nominal dimensions, total yield values of $33.4 \%$ (maple) and $33.2 \%$ (ash) could be obtained. For future investigations, it is planned to evaluate the influence round wood quality has on presorting and planning losses. Especially for low dimension logs of poor quality the question arises, how much of the resulting twisting and bowing in the dried lumber is due to the drying process and how much is already present in the rough green lumber.

\subsection{Strength grading of glulam lamellas (planed boards)}

\subsubsection{Grading results}

As explained in section 4.5 , the planed boards were graded visually according to the German visual strength grading standard DIN 4074-5 [16]. Furthermore, the result of two adjusted grading schemes were compared - when the criterion "pith" is excluded from visual strength grading 
442 according to DIN 40745 [16] and when only single knots (DEB) are evaluated according to DIN 4074-

4435 [16]. Additionally, the lamellas were graded following the combined visual and machine grading 444 proposed by Kovryga et al. [31] and presented in Table 3.

445 Figure 3 shows the grading results for ash and maple respectively. The second box of each 446 diagram gives the results of visual grading according to DIN 4074-5 [16]. For both ash and maple,

447 only few boards are sorted into the classes LS7 and LS10. The majority is either sorted into the highest

448 quality class LS13 or rejected. When excluding the criterion pith from DIN 4074-5 [16] sorting (see

449 third box), no ash lamellas and four maple lamellas were rejected. The majority of the lamellas is

450 graded into LS13 (ash: 195; maple: 238). Only applying the DIN 4074-5 [16] boundary values for the

451 criterion DEB (single knot) gives almost identical sorting results. The combined grading proposed

452 and optimized by Kovryga et al. [31] for the here studied lamellas result in a relatively even

453 distribution of lamellas over the three grades. For ash $6.8 \%$ and for maple $15.7 \%$ of the lamellas are

454 rejected. 
Ash
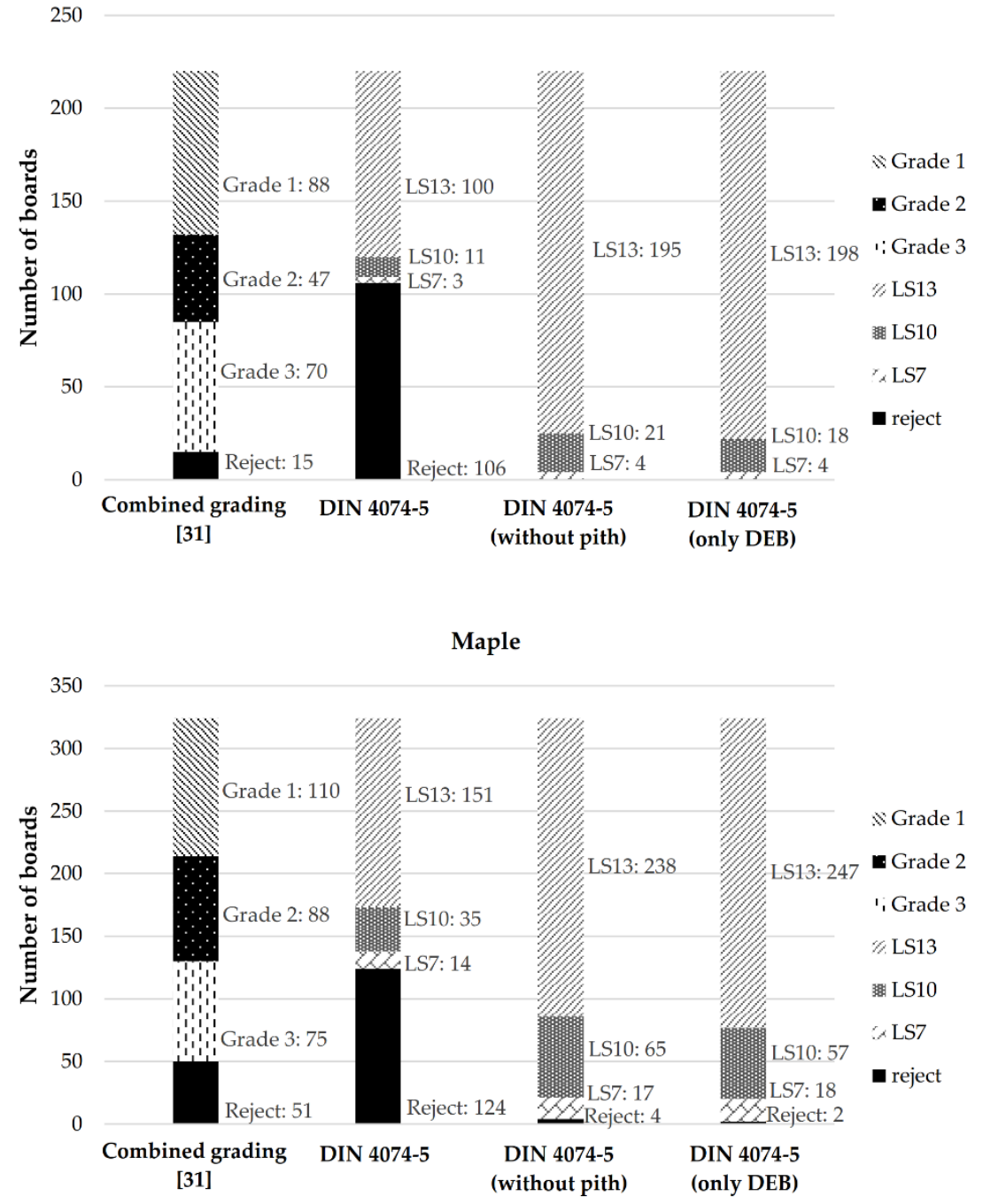

Figure 3: Yields for the combined (left bar) and visual grading (three right bars) of the planed ash and maple boards.

For grading according to DIN 4074-5 [16], a high effect of the pith criterion on the grade class assignment can be stated. Grading with pith as rejection criterion results in a reject rate of $48 \%$ for the ash boards and $38 \%$ for the maple boards. If the pith criterion is excluded from grading, none of the ash boards and only $1 \%$ of the maple boards are rejected. Similar results are reported by Torno et al. [12], who detect pith in $26 \%$ and $30 \%$ of the graded beech boards. Here the sawing pattern was similar to this study, but logs with bigger diameters were sawn. Van de Kuilen and Torno [15] calculate for their study the ratio of pith containing board volume to initial round wood volume 
(inside bark) to be $0.2 \%$ for ash and $0.9 \%$ for beech. In this study, this ratio is $9.1 \%$ for ash and $8.0 \%$ for maple. This much higher appearance of pith can be explained by the fact that lower dimension logs were sawn and the overall log quality was poorer. Furthermore, the study of Van de Kuilen and Torno [15] used a special sawing pattern ("sawing around the log" or "grade sawing") designed to produce boards without pith. Generally, it can be concluded that the sawing pattern and the low log dimensions chosen for this study result in a high amount of pith boards, which have to be sorted out, when sorting according to DIN 4074-5 [16]. Pith is also the main downgrading criterion in the grading of ash and maple lamellas studied by Glos and Torno [28]. The rest of the boards of this study show good quality for both species, resulting in a high proportion in LS13 grading.

One explanation for the higher amount of pith containing boards in the ash compared to the maple collective can be the fact that in ash trees the pith is typically "wandering", which is due to crooked growth in early years $[17,36]$. Other reasons can be more severe bowing of the ash logs or littler log dimensions. Figure 4 proves that the small-end diameters are not severely different for the 81 maple and 79 ash log sections.
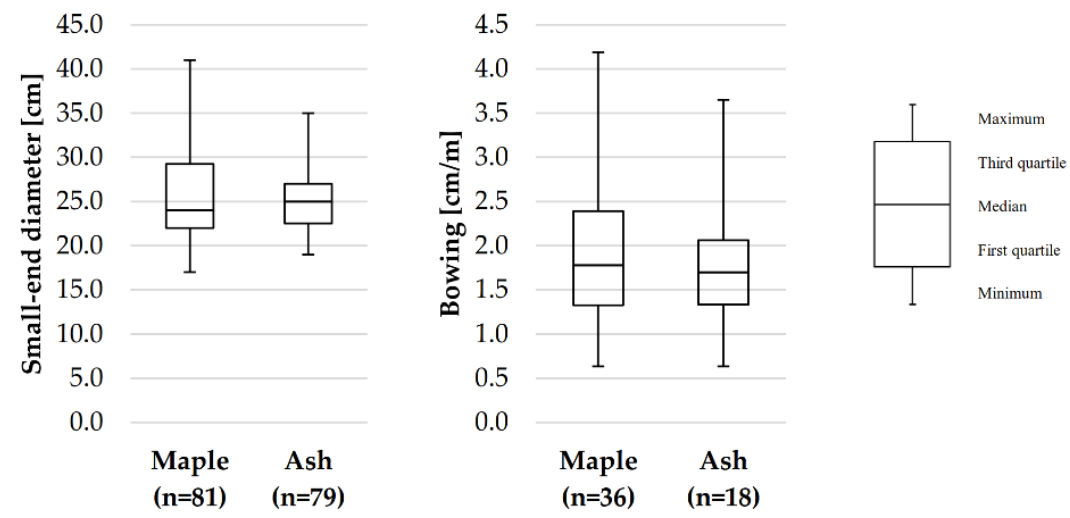

Figure 4: Boxplots for log section small-end diameter and bowing (only in one direction according to RVR instructions) separated after species ( $\mathrm{n}=$ number of log sections).

The bowing of the raw material was according to RVR [29] specifications only measured for log sections that had one bow over the entire log length. This criterion shows now difference between the species ash and maple as well (see Figure 4). Checking the number of logs with compound bowing (bowing into two or more directions) reveals a different picture, though. While only $55 \%$ of the maple $\log$ sections are characterized by compound bowing, $77 \%$ of the ash log sections have compound bows. This could be an explanation for the higher amount of pith containing boards in the ash collective. Since the collected data does not contain information on the degree of compound bowing, one cannot distinguish between the influence of the "wandering pith" and the log section bowing.

To finalize the discussion of the effect of the grading parameters on the yield, the effect of the knot cluster criterion (DAB) is observed. Comparing both visual grading options - for DIN 4074-5 [16] "without considering pith" and "only DEB (without considering pith and DAB)" - little to no changes can be observed (see Figure 3). The added value (information) of DAB for grading is illustrated in Figure 5, which plots the maximum DEB against maximum DAB values for all ash and maple boards. The paired values (boards) on the bisector show those boards, where the maximum $\mathrm{DEB}$ is bigger than or equal to any found DAB. For all other boards a DAB bigger then the DEB is reported. The grey area indicates those boards, for which the criterion DAB leads to a sorting class downgrading, when sorting according to for DIN 40745 [16]. This is the case for only twelve maple 
boards $(3.7 \%)$ and three ash boards $(1.4 \%)$. Therefore, the criterion knot cluster (DAB) is not decisive for downgrading into a lower sorting class, if graded after DIN 4074-5 [16].

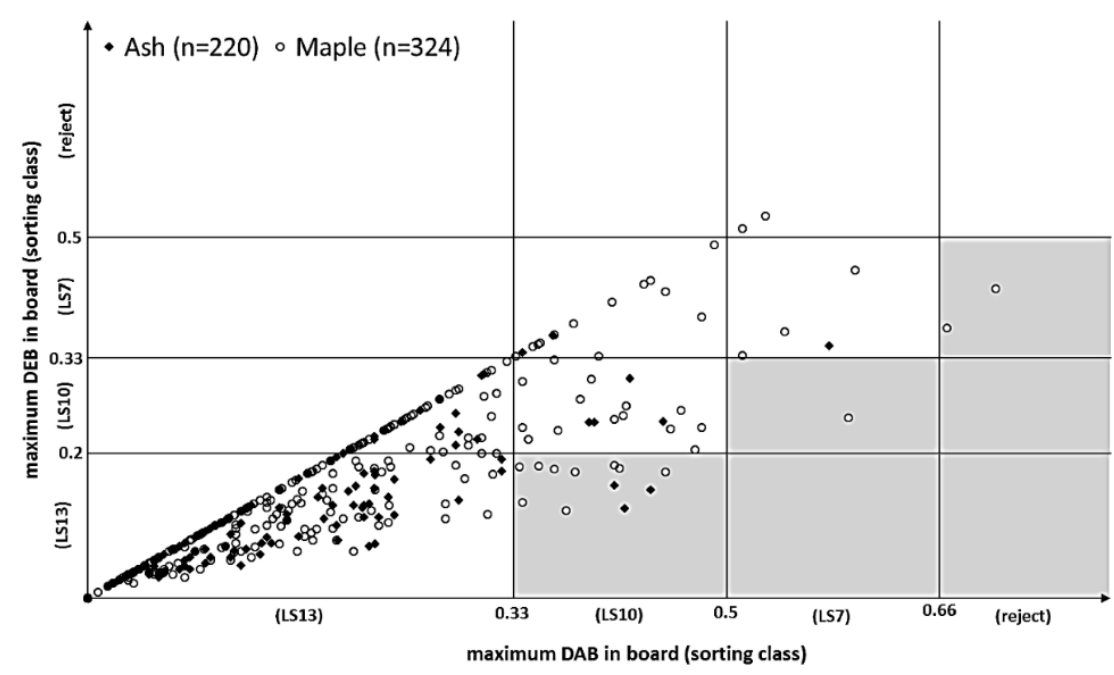

Figure 5: Maximum knot ratio of single knot (DEB) and knot cluster (DAB) for ash and maple boards. For all boards in grey area the criterion knot cluster (DAB) leads to downgrading into lower sorting class.

This confirms the findings made by other authors for the hardwood species beech. Frese and Riedler [38] postulate that for flat sawn beech lamellas (with lying annual rings) the sorting criterion $\mathrm{DAB}$ is not decisive for downgrading. Glos and Lederer [33] state that out of 219 beech boards only for one board the criterion $\mathrm{DAB}$ is sorting class determining. Blaß et al. [2] find similar results for a set of 350 beech boards (for $1.4 \%$ DAB decisive) and another set of 1888 beech boards (for $0.4 \%$ DAB decisive).

When applying stricter boundary values for the DAB than stated by the DIN 4074-5 [16], the $D A B$ 's influence on the grade rises. In the combined grading proposed by Kovryga et al. [31], the boundary values for DEB and DAB for ash are set identical - i.e. the strictest DAB setting possible. Thus, $13.6 \%$ of the ash lamellas of this study are downgraded due to the criterion DAB (cluster knot). For maple grading according to the settings proposed by Kovryga et al. [31] only $6.5 \%$ of the studied lamellas are downgraded due to the criterion DAB (cluster knot). This is, because the proposed DAB boundary values for maple are not as strict as for ash. Regarding knot clusters (DAB), Figure 5 suggests that the investigated maple wood contains proportionally more knot clusters than the ash wood. Further analysis reveals only a difference of $6 \%$, though. $33 \%$ of the ash boards and $39 \%$ of the maple boards contain knot clusters (bigger than the max. DEB). Figure 6 shows that these maximum knot clusters are bigger in the maple collective than in the ash collective. The same holds for single knots. This leads to a higher proportion of LS7 and LS10 boards in the maple collective compared to the ash group (see Figure 3 ). 

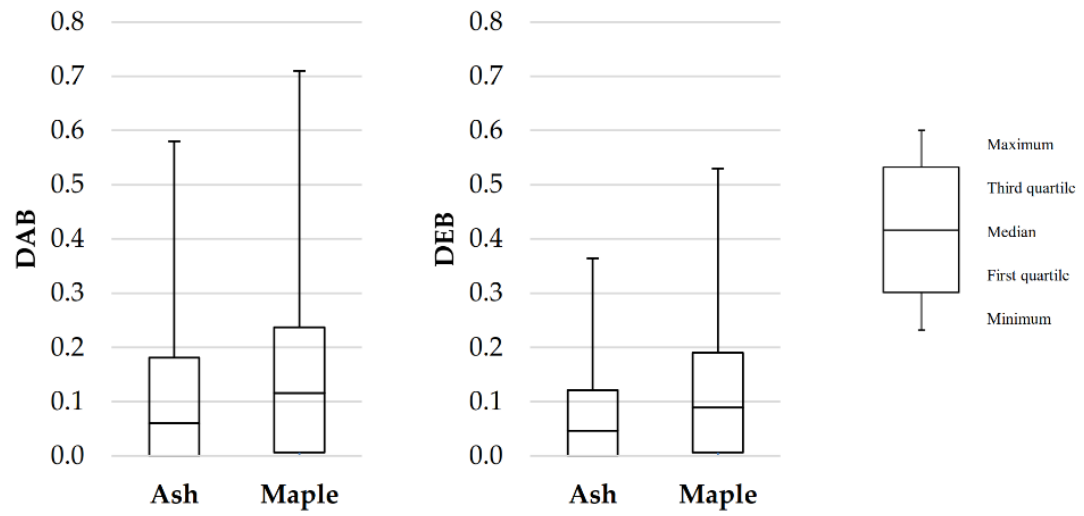

Figure 6: Boxplots separated after sorting criteria (maximum DEB and DAB in board) and species.

520

In general, special care must be taken, when comparing grading results of different publications. The research material can be extremely diverse (i.e. species, origin, quality, sawing pattern, etc.), but also data acquisition for grading can be different. For example, Glos and Torno [28] grade the evaluated lumber only after the sorting criteria occurring within the tension test length, while for this study the entire board length is evaluated. Furthermore, the sorting criterion "grain angle" is a source of confusion, since its visual determination on unbroken boards is problematic [33,34].

\subsubsection{Yields of graded lumber}

The four sorting schemes presented in Figure 3 lead to different rates of so-called "rejects", i.e. boards that have to be sorted out. Table 8 lists the relative and absolute losses for the production step "grading" for each grading scheme and the resulting overall yields (referring to the round wood volume). 
Table 8: Volume yields for the production step grading (from planed board to graded lamella) for four different grading schemes.

\begin{tabular}{|c|c|c|c|c|c|c|c|c|c|}
\hline \multirow{3}{*}{ Product } & \multirow{3}{*}{$\begin{array}{c}\text { Options for production step } \\
\text { grading }\end{array}$} & \multicolumn{4}{|c|}{ Maple } & \multicolumn{4}{|c|}{ Ash } \\
\hline & & \multicolumn{2}{|c|}{ Yield } & \multicolumn{2}{|c|}{ Waste/Loss } & \multicolumn{2}{|c|}{ Yield } & \multicolumn{2}{|c|}{ Waste/Loss } \\
\hline & & in $\mathrm{m}^{3}$ & in $\%$ & in $\mathbf{m}^{3}$ & in $\%$ PS & in $\mathrm{m}^{3}$ & in $\%$ & in $\mathrm{m}^{3}$ & in $\%$ PS \\
\hline $\begin{array}{l}\text { Boards planed } \\
\text { (unsorted lamellas) }\end{array}$ & & 3.3 & 20.9 & & & 2.6 & 18.2 & & \\
\hline & $\begin{array}{l}\text { Grading I (Combined grading } \\
\text { acc. to Kovryga et al. [31]) }\end{array}$ & & & 0.5 & 15.7 & & & 0.2 & 6.8 \\
\hline $\begin{array}{l}\text { Combined grading } \\
\text { lamellas }\end{array}$ & & 2.8 & 17.8 & & & 2.4 & 17.0 & & \\
\hline & Grading II (4074-5) & & & 1.3 & 39.0 & & & 1.3 & 49.8 \\
\hline 4074-5 lamellas & & 2.0 & 12.7 & & & 1.3 & 9.1 & & \\
\hline & $\begin{array}{l}\text { Grading III (4074-5 without } \\
\text { pith) }\end{array}$ & & & 0.04 & 1.3 & & & 0 & 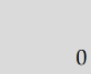 \\
\hline $\begin{array}{l}\text { 4074-5 lamellas } \\
\text { without pith }\end{array}$ & & 3.3 & 20.6 & & & 2.6 & 18.2 & & \\
\hline & $\begin{array}{l}\text { Grading IV (4074-5, only } \\
\text { DEB) }\end{array}$ & & & 0.02 & 0.7 & & & 0 & 0 \\
\hline $\begin{array}{l}\text { 4074-5 lamellas } \\
\text { (only DEB) }\end{array}$ & & 3.3 & 20.8 & & & 2.6 & 18.2 & & \\
\hline
\end{tabular}

When grading the lamellas according to DIN 4074-5 [16], for ash yield values lie around $9 \%$, for maple around $13 \%$. When excluding the sorting criterion "pith", total yields of ash are doubled (18.2 $\%$ ), those of maple rise to $20.6 \%$. The difference between grading scheme III and IV is very little to none. This is due to the fact that the DAB $(\mathrm{KC})$ has very little influence on the strength grading according to DIN 4074-5 [16].

As Table 8 shows, excluding the sorting criterion pith from the sorting scheme, raises the final yield considerably. Since board tension strength is the key influencing factor on glulam bending strength, tension testing of glulam lamellas has to show the effect the pith has on the board tension strength and stiffness (see [31]). If this influence is neglectable, the yield of grading can be raised extremely. It is important to state, though, that this does not hold equally for other strength properties. Glos and Torno [28], for example, prove for ash and maple that pith has a significant influence on the bending strength of square-edged lumber. They also stress the fact that the appearance of pith is often accompanied by bows, twists and cracks. Similar results are presented by Glos and Lederer [33] for beech and oak square-edged lumber. Hübner [39] proves the pith' significant influence on the tension strength perpendicular to grain of ash glulam.

Further research has to work towards a hardwood strength grading system, which is based on the mechanical properties of the resulting glulam. Kovryga et al. [31] proposes different optimized grading schemes for ash and maple glulam lamellas. For this study, one optimized combined grading solution from Kovryga et al. [31] was chosen for each species (see Table 3) to show an example of resulting yield. The chosen grading scheme distinguishes between three grades resulting in three board tensile strength classes based on destructive tension testing. For ash, the lowest class is DT22 with a characteristic tensile strength higher than $22 \mathrm{~N} / \mathrm{mm}^{2}$. For hardwoods, Kovryga et al. [40] proposes no tensile strength class lower than DT18. For lower mechanical properties softwood TClasses can be used. Therefore, for maple the lowest class is T15 (softwood tensile strength class) with a characteristic tensile strength not lower than $15 \mathrm{~N} / \mathrm{mm}^{2}$ (see Table 3). In this study, the proposed 
strength grading results in $15.7 \%$ rejects for maple and $6.8 \%$ rejects for ash. The resulting yields of $17.8 \%$ and $17.0 \%$ are considerably higher compared to grading according to DIN 4074-5 [16].

The economic feasibility of the production of hardwood glulam is strongly influenced by the final yield of glulam lamellas. Torno et al. [12] calculate that the production of beech glulam lamellas costs at least three times as much as that of spruce lamellas, calculating with beech round wood prices of 53.50 to $80.00 €$ per cubic meter. Since final yield figures of this study and Torno et al. [12] lie in a similar range, these costs can also be assumed for the lamellas of this study. This makes raising the yield inevitable, if a competitive hardwood product shall be produced.

When evaluating the competitiveness of a product, not only the production cost, but also the added value should be considered. Following the proposed combined grading of Kovryga et al. [31], for this study strength classes with a characteristic tensile strength as high as $38 \mathrm{~N} / \mathrm{mm}^{2}$ can be produced. With ash lamellas of this characteristic strength, glulam with bending strength values of as high as $48 \mathrm{~N} / \mathrm{mm}^{2}$ can be achieved [4]. Via "upgrading", i.e. cutting out big knots, the characteristic tensile strength of ash lamellas can be raised up to $54 \mathrm{~N} / \mathrm{mm}^{2}$ [31]. Using the combined grading approach for beech lamellas, Erhardt et al. [41] report tensile strength values of as high as $50 \mathrm{~N} / \mathrm{mm}^{2}$. This raised strength allows the production of more slender structures, which means material savings but also more construction possibilities for the architect and engineer. The listed benefits would yield obviously in higher reward for the producer. Although the present market situation has not led to a wide spread use of hardwood glulam, future changes in spruce availability, round wood prices (especially hardwood) and wood processing technology (etc.) might make the production lucrative.

\section{Conclusions}

For this study, the volume yields of the production of glulam lamellas from low quality and low dimension ash and maple log sections are investigated. For this purpose, $16.25 \mathrm{~m}^{3}$ of maple $(81 \mathrm{log}$ sections) and $14.89 \mathrm{~m}^{3}$ of ash (79 log sections) were harvested from natural forest stands (mixed beech forests) in central Germany and were turned into dry-dressed lumber (unsorted lamellas) with state of the art technologies. The resulting board volumes amount for only $20.9 \%$ (maple) and $18.2 \%$ (ash) of the original $\log$ volumes. The most waste is produced in the production step "presorting \& planing" (maple: $56 \%$; ash: $60 \%$ ), since here a high percentage of the boards has to be sorted out due to bowing. By trimming these boards to shorter lengths, the waste of this production step could be reduced considerably. In addition, the sawing (milling) of the boards produced in both cases around $50 \%$ waste, which is in line with the above mentioned literature values for sawing low quality hardwoods. Nonetheless, with an adjusted sawing technology, this waste can be reduced (e.g. through shorter log sections and optimized machine combinations). It is also advisable to define a minimum input log diameter, since the lower the log diameter is, the lower the volume yield of milling gets. Another approach to a raised final volume and value yield is the diversification of final products. Thus, as an example, glulam lamellas could be produced as low quality co-product from the production of high quality lumber for furniture production.

Strength grading of lamellas lowers final volume yields even further. When sorting the lamellas according to DIN 4074-5 [16], final volume yields of $12.7 \%$ for maple and $9.1 \%$ for ash are attained. One way of raising the final volume and also value yield could be the adjustment of the sorting (grading) scheme. For example, by excluding the criterion "pith" from sorting, final yield values of $20.6 \%$ (maple) and $18.2 \%$ (ash) can be achieved. Generally, it is advisable to combine visual and machine sorting to an assortment and species adjusted combined grading, which is optimized after the criteria "desired tensile strength and stiffness" but also "yield". The paper Kovryga et al. [31] is attempting this. Resulting total yields, when applying the selected optimized combined grading of Kovryga et al. [31] to this study's lumber, lie between $17 \%$ and $18 \%$. This yield is considerably lower than that obtained for softwood glulam lamellas. Factors like the higher attainable tensile strength, if compared to $30 \mathrm{~N} / \mathrm{mm}^{2}$ possible for softwoods [42], and the appealing appearance of hardwood glulam may make up for the yield disadvantages. In general, the economic feasibility of hardwood glulam is influenced by a serious of factors, which have to be analyzed in detail for each final product and production plant separately. 
612 Author Contributions: conceptualization, methodology, investigation, formal analysis, visualization and

613 writing - original draft preparation P.S. and A.K.; data curation and investigation L.E.; funding acquisition,

614 project administration, supervision and writing - review and editing S.B.; resources, supervision and writing-

615 review and editing J.W.V.d.K. and H.M.

616 Funding: This study was funded by the German Federal Ministry of Food and Agriculture (grant number 617 22024211).

618 Acknowledgments: We thank Dr. Antje Gellerich for giving helpful advice during data acquisition.

619 Conflicts of Interest: The authors declare no conflict of interest.

\section{References}

621 1. Sauter, U. WP 1: Hardwood resources in Europe - Standing stock and resource forecasts. Presentation at workshop "European hardwoods for the building sector", Garmisch-Patenkirchen, Germany, 2016.

2. Blaß, H.J.; Denzler, J.; Frese, M.; Glos, P.; Linsenmann, P. Biegefestigkeit von Brettschichtholz aus Buche [Bending strength of beech glulam], Karlsruher Berichte zum Ingenieurholzbau, Band 1 Karlsruher Berichte zum Ingenieurholzbau; Universitätsverlag Karlsruhe: Karlsruhe, Germany, 2005.

3. Frühwald, A.; Ressel, J.B.; Bernasconi, A.; Becker, P.; Pitzner, B.; Wonnemann, R.; Mantau, U.; Sörgel, C.; Thoroe, C.; Dieter, M.; Englert, H. Hochwertiges Brettschichtholz aus Buchenholz [High quality glulam made of beech wood], Final report; University of Hamburg: Hamburg, Germany, 2003.

4. Van de Kuilen, J.W.; Torno, S. Materialkennwerte von Eschenholz für den Einsatz in Brettschichtholz [Material properties of ash wood for the use in glulaml, Final report; Holzforschung München, Technische Universität München: Munich, Germany, 2014.

5. DIBt. BS-Holz aus Buche und BS-Holz Buche-Hybridträger [Glulam and hybrid glulam made of beech]; German technical building approval Z-9.1-679; holder of approval: Studiengemeinschaft Holzleimbau e.V., Germany; issued by Deutsches Institut für Bautechnik (DIBt), Germany; valid until 27.10.2019; 2014.

6. OiB. VIGAM - Glued laminated timber of oak; ETA-13/0642 European Technical Approval; holder of approval: Elaborados y Fabricados Gámiz S.A., Spain; issued by Austrian Institute of Construction Engineering (OiB), Austria; valid until 27.06.2018; 2013.

7. DIBt. Holz Schiller Eiche-Pfosten-Riegel- Brettschichtholz [Timber Schiller oak post and beam glulam]; German technical building approval Z-9.1-821; holder of approval: Holz Schiller GmbH, Germany; issued by Deutsches Institut für Bautechnik (DIBt), Germany; valid until 02.03.2018; 2013.

8. OiB. Sierolam - Glued laminated timber of chestnut; ETA-13/0646 European Technical approval; holder of approval: Siero Lam S.A., Spain; issued by Austrian Institute of Construction Engineering (OiB), Austria; valid until 27.06.2018; 2013.

9. Mack, H. Der europäische Markt für Brettschichtholz (BSH) - Ergebnisse einer Umfrage innerhalb der europäischen Leimholzindustrie [The European market for glulam - Results of a survey within the European glued timber industry]. Presentation at „Wiener Leimholz Symposium 2006“, Vienna, Austria, 23-24 March 2006; pp. 35-50.

10. Ohnesorge, D.; Hennig, M.; Becker, G. Bedeutung von Laubholz bei der Brettschichtholzherstellung [Significance of hardwoods in glulam production]. Holztechnologie 2009, 6, 47-49. Verwendung [Differences between hard- and softwoods and their influence on processing and use]. Presentation at "Gülzower Fachgespräche Stoffliche Nutzung von Laubholz", Würzburg, Germany, 
654 12. Torno, S.; Knorz, M.; Van de Kuilen, J.W. Supply of beech lamellas for the production of glued laminated timber. In Proceedings of the 4th International Scientific Conference on Hardwood

13. Wiedenbeck, J.; Scholl, M.S.; Blankenhorn, P.R.; Ray, C.D. Lumber volume and value recovery from small-diameter black cherry, sugar maple, and red oak logs. BioResources 2017, 12, 853-870.

14. Lin, W.; Wang, J.; Wu, J.; DeVallance, D. Log Sawing Practices and Lumber Recovery of Small Hardwood Sawmills in West Virginia. For. Prod. J. 2011, 61, 216-224.

15. Van de Kuilen, J.W.; Torno, S. Untersuchungen zur Bereitstellung von Lamellen aus Buchen- und Eschenholz für die Produktion von Brettschichtholz [Studies on the supply of lamellas for the production of glulam from beech and ash wood], Final report X37; Holzforschung München, Technische Universität München: Munich, Germany, 2014.

16. DIN 4074-5. Strength grading of wood - Part 5: Sawn hardwood; German Institute for Standardization (DIN): Berlin, Germany, 2008.

17. Ehlebracht, V. Untersuchung zur verbesserten Wertschöpfung bei der Schnittholzerzeugung aus schwachem Buchenstammholz (Fagus sylvatica L.) [Investigation on improved added value in the production of sawn lumber from low dimension beech timber]. Dissertation, Georg-August-Universität Göttingen, Göttingen, 2000.

18. Eickers, A. Verschnittuntersuchungen bei der Verarbeitung von Brettschichtholzlamellen [Yield loss in the production of glulam lamellas]. Diploma thesis, Fachhochschule Hildesheim/Holzminden, Hildesheim, 1997.

19. Steele, P.H. Factors Determining Lumber Recovery in Sawmillin, General Technical Report FPL-39; U.S. Department of Agriculture, Forest Service, Forest Products Laboratory: Madison, WI, USA, 1984.

20. Richards, D.B.; Adkins, W.K.; Hallock, H.; Bulgrin, E.H. Lumber values from computerized simulation of hardwood log sawing, Research Paper FPL-356; U.S. Department of Agriculture, Forest Service, Forest Products Laboratory: Madison, WI, USA, 1980.

21. Emhardt, M.; Pfingstag, S. Schnittholzqualität und Ausbeute von schwachem Buchenstammholz [Sawn lumber quality and yield produced from low dimension beech logsl, Final report; FVA Baden-Würtemberg: Freiburg, Germany, 1993.

22. Fronius, K. Arbeiten und Anlagen im Sägewerk - Spaner, Kreissäge, Bandsäge [Work and machines in a sawmill chipper canter, circular saw, band saw], 2nd ed.; DRW-Verlag Weinbrenner: Leinfelden-Echterdingen, Germany, 1989.

23. Fischer, H. Neue Verwendungsmöglichkeiten von Laubschwachholz [New possible uses for low dimensions hardwood timber], Internal report; Forstliche Versuchsanstalt Rheinland-Pfalz, Germany, 1996.

24. Lamb, F.M.; Wengert, E.M. Techniques and procedures for the quality drying of oak lumber. In Proceedings of the 41st Meeting of the Western Dry Kiln Association, Corvallis, Oregon, USA, 1990.

25. Denig, J.; Wengert, E.M.; Simpson, W.T. Drying Hardwood Lumber, General technical report FPL-GTR118; U.S. Department of Agriculture, Forest Service, Forest Products Laboratory: Madison, WI, USA, 2000.

26. Kollmann, F.; Côté Jr, W.A. Principles of Wood Science and Technology, I. Solid Wood; Springer: Berlin, Heidelberg, 1968.

27. Wagenführ, R. Holzatlas; Fachbuchverlag im Carl Hanser Verlag: Leipzig, Germeny, 2007.

28. Glos, P.; Torno, S. Aufnahme der einheimischen Holzarten Ahorn, Esche und Pappel in die europäische Norm EN 1912: „Bauholz - Festigkeitsklassen - Zuordnung von visuellen Sortierklassen und Holzarten“ [Inclusion of tha 
native wood species maple, ash and poplar in the European standard EN 1912: "Structural timber - Strength

classes - Assignment of visual grades and species"], Final report 06517; Holzforschung München, Technische

Universität München: Munich, Germeny, 2008.

29. RVR. Rahmenvereinbarung für den Rohholzhandel in Deutschland (RVR) [Framework agreement on raw timber

trade in Germany]; Deutscher Forstwirtschaftsrat \& Deutscher Holzwirtschaftsrat, 2015.

30. DIN 1316-3. Hardwood round timber - Qualitative classification - Part 3: Ash and maples and sycamore. German Institute for Standardization (DIN): Berlin, Germany, 1997.

31. Kovryga, A.; Schlotzhauer, P.; Stapel, P.; Militz, H.; Van de Kuilen, J.W. Visual and machine strength grading of European ash and maple for glulam application. Holzforschung 2019, 0.

32. Hankinson, R.L. Investigation of Crushing Strength of Spruce at Varying Angles of Grain, Air Service Information Circular No. 259; U.S. Air Service, 1921.

33. Glos, P.; Lederer, B. Sortierung von Buchen-und Eichenschnittholz nach der Tragfähigkeit und Bestimmung der zugehörigen Festigkeits-und Steifigkeitskennwerte [Strength grading of beech and oak lumber and determination of characteristic strength and stiffness values], Final report; Institut für Holzforschung, Technische Universität München: Munich, Germany, 2000.

34. Frühwald, A.; Schickhofer, G. Strength grading of hardwoods. In Proceedings of the 14th International Symposium on Nondestructive Testing of Wood, Eberswalde, Germany, 2-4 May 2005.

35. Frese, M.; Blaß, H.J. Beech glulam strength classes. In Proceedings of Meeting 38 of the International Council of research and innovation in building and construction, Working commission W18 - Timber structures, Karlsruhe, Germany, 2005.

36. Wade, M.W.; Bullard, S.H.; Steele, P.H.; Araman, P.A. Estimating Hardwood Sawmill Conversion Efficiency Based on Sawing Machine and Log characteristics. For. Prod. J. 1992, 42, 21-26.

37. Torno, S.; Van de Kuilen, J.W. Esche für tragende Verwendungen - Festigkeitseigenschaften visuell sortierten Eschenholzes [Ash for load bearing use - strength properties of visually graded ash lumber]. LWF Aktuell 2010, 77, 18-19.

38. Frese, M.; Riedler, T. Untersuchung von Buchenschnittholz (Fagus sylvatica L.) hinsichtlich der Eignung für Brettschichtholz [Examination of suitability of beech lumber for glulam]. Eur. J. Wood Wood Prod. 2010, 68, 445-453.

39. Hübner, U. Mechanische Kenngrößen von Buchen-, Eschen- und Robinienholz für lastabtragende Bauteile [Mechanical parameters of beech, ash and locust lumber for load bearing members]. Doctoral thesis, Technische Universität Graz, Graz, 2013.

40. Kovryga, A.; Stapel, P.; Van De Kuilen, J.W. Tensile strength classes for hardwoods; In Proceedings of the 49th INTER \& CIB Meeting, Graz, Austria, 2016. production of GLT \& CLT. In Proceedings of the 49th INTER \& CIB Meeting, Graz, Austria, 2016. 2016. 


\section{Paper c}

Visual and machine strength grading of European ash and maple for glulam application 
Andriy Kovryga*, Philipp Schlotzhauer, Peter Stapel, Holger Militz

and Jan-Willem G. van de Kuilen

\section{Visual and machine strength grading of European ash and maple for glulam application}

https://doi.org/10.1515/hf-2018-0142

Received June 21, 2018; accepted February 5, 2019; previously published online $x x$

Abstract: Medium dense hardwoods (HWs) show higher tensile strength (TS) values than softwoods (SWs). These advantages cannot be utilised effectively because HW grading is not well developed. The aim of the present paper was to analyse the utilisation potential of European ash (Fraxinus spp.) and maple (Acer spp.) grown in Central Europe, which were graded by different methods. The visual grading characteristics of $869 \mathrm{HW}$ boards were determined and the dynamic modulus of elasticity $\left(\mathrm{MOE}_{\mathrm{dyn}}\right)$ and X-ray attenuation (XRA) were measured by an industrial scanner. The specimens were subsequently tested in tension according to EN 408:2010 and according to German visual grading rules show strength values of $28 \mathrm{MPa}$ and $30 \mathrm{MPa}$, respectively. Machine strength grading and for a combination of manually assessed boards and $\mathrm{MOE}_{\mathrm{dyn}}$ give rise to higher strength data. $\mathrm{MOE}_{\mathrm{dyn}}$, in particular, results in lamella data with $62 \mathrm{MPa}$ for ash and $42 \mathrm{MPa}$ for maple. There is good agreement with recently presented HW tensile profiles. Machine grading with a multisensor system allows better strength prediction compared to the $\mathrm{MOE}_{\mathrm{dyn}}$ or visual strength grading. Best performance is achieved by a combined grading approach.

Keywords: dynamic MOE, glulam, grading of hardwoods, hardwoods, machine grading, mechanical properties of hardwoods, multisensor system, optimisation, strength profiles, tensile strength, visual strength grading, X-ray attenuation (XRA)

\footnotetext{
*Corresponding author: Andriy Kovryga, Holzforschung München, Technical University of Munich, 80797 Munich, Germany, e-mail: kovryga@hfm.tum.de Philipp Schlotzhauer and Holger Militz: Wood Biology and Wood Products, Georg August University of Göttingen, 37077 Göttingen, Germany

Peter Stapel: Holzforschung München, Technical University of Munich, 80797 Munich, Germany

Jan-Willem G. van de Kuilen: Holzforschung München, Technical University of Munich, 80797 Munich, Germany; and Faculty of Civil Engineering and Geosciences, Delft University of Technology, Delft, The Netherlands
}

\section{Introduction}

The forestry policy in Europe is changing towards mixed forests, with a higher proportion of temperate hardwood (HW, abbreviations are summarised in Table 1) species, which are becoming more interesting from the climate change point of view (Kolling 2007). Exemplarily, the total share of HW in Germany increased between 2002 and 2014 by $7 \%$ and accounts for $43 \%$ of the total forestry area (BMEL 2015). European beech and oak have a share of $59.4 \%$ of the HW areas, but also ash, maple, lime, elm and many other species can be found in the mixed forests. The excellent mechanical HW properties (Kollmann and Côté 1968) are favourable for construction wood allowing for creating slenderer structural elements, reaching longer spans or for locally strengthening of softwood (SW) elements. Hitherto, oak, beech, chestnut, birch woods have the highest potential as structural elements (Aicher et al. 2014; Aicher and Stapf 2014; Frese and Blaß 2007; Jeitler et al. 2016). The HW glulam elements from ash and maple are also promising (Van de Kuilen and Torno 2014). In North America, maple glulam has a still unused high application potential (Manbeck et al. 1993; Janowiak et al. 1997). The key issues of HW glulam are the bonding and strength grading of the lamellas including the selection of an appropriate adhesive system and the durability of the composites (Aicher and Reinhardt 2007; Konnerth et al. 2016). Individualised bonding systems are necessary in view of the variability of HW species (Konnerth et al. 2016). The improvement of structural bonding of hardwoods is a hot spot research area (Schmidt et al. 2010, 2012; Knorz et al. 2014; Luedtke et al. 2015; Ammann et al. 2016).

Strength grading of $\mathrm{HW}$ lamellas will also be addressed in the present paper, dealing with the assignment into strength classes concerning strength, stiffness and density based on some visible or non-visible characteristics. The resulting parameters are required for modelling of glulam beams (Frese and Blaß 2007). The applied methodology is similar to that known from softwoods (SW) classification. Visual strength grading is a traditional approach relaying on the number and size of knots and the slope of grains. This cost-saving approach is also popular in HW sawing mills of small and medium size 
Table 1: List of symbols and abbreviations.

\begin{tabular}{|c|c|}
\hline Symbol, abbreviation & Definition \\
\hline BAY & Bavaria, state in Germany \\
\hline CDF & Cumulative distribution function \\
\hline $\mathrm{CV}$ & Coefficient of variation \\
\hline DENS & Density, mesured using XRA $\left(\mathrm{kg} \mathrm{m}^{-3}\right)$ \\
\hline $\mathrm{E}$ & Edge knot, grading criterion after DIN 4074-5 (2008) (-) \\
\hline$E_{0 \text { mean }}$ & Modulus of elasticity parallel to the grain (MPa) \\
\hline $\mathrm{E}_{\mathrm{t}, \mathrm{m} \text { mean }}$ & Modulus of elasticity in tension (GPa) \\
\hline$f_{t}$ & Tensile strength parallel to the grain (MPa) \\
\hline$f_{t, 0, k}^{t}$ & Tensile strength parallel to the grain, $5^{\text {th }}$ percentile value (MPa) \\
\hline HW & Hardwoods \\
\hline IP & Indicating property \\
\hline IP DENS & Modelled density $\left(\mathrm{kg} \mathrm{m}^{-3}\right)$ \\
\hline $\mathrm{IPf}_{\mathrm{t}}$ & Modelled tensile strength (MPa) \\
\hline $\mathrm{IP}_{\mathrm{KNOTS}}$ & Machine measured knotiness parameter (-) \\
\hline IP MOE & Modelled modulus of elasticity (GPa) \\
\hline KC & Knot cluster, multiple knot criterion after DIN 4074-5 (2008) (-) \\
\hline MC & Moisture content \\
\hline MOE & Modulus of elasticity \\
\hline $\mathrm{MOE}_{\mathrm{dyn}}$ & Dynamic modulus of elasticity (GPa) \\
\hline $\mathrm{MOE}_{\text {static }}$ & Static modulus of elasticity ( $\mathrm{GPa}$ ) \\
\hline $\mathrm{n}$ & Number of specimens \\
\hline $\mathrm{Q}_{0.05}$ & $5^{\text {th }}$ percentile value \\
\hline $\mathrm{R}^{2}$ & Coefficient of determination (-) \\
\hline $\mathrm{RH}$ & Relative humidity \\
\hline$\rho$ & Density $\left(\mathrm{kg} \mathrm{m}^{-3}\right)$ \\
\hline$\rho_{k}$ & Density, $5^{\text {th }}$ percentile value $\left(\mathrm{kg} \mathrm{m}^{-3}\right)$ \\
\hline SK & Single knot, important grading criterion after DIN 4074-5 (2008) (-) \\
\hline SW & Softwood \\
\hline $\mathrm{TH}$ & Thuringia, state in Germany \\
\hline TS & Tensile strength \\
\hline XRA & $\mathrm{X}$-ray attenuation \\
\hline$\mu$ & Mean value \\
\hline
\end{tabular}

companies. The prediction accuracy of the strength based on visual grading criteria results in $\mathrm{R}^{2}$ values between 0.3 and 0.7 in the case of temperate HW species such as ash, beech, and oak (Oliver-Villanueva et al. 1996; Glos and Lederer 2000; Frühwald and Schickhofer 2005; Van de Kuilen and Torno 2014; Ehrhart et al. 2016a). For knot free HW specimens, the fibre deviation is an important criterion, but it is difficult to quantify. The fibre orientation on drying checks or the scribbling method on the wood surface are known approaches, but the reliability of booth methods is very limited (Glos and Lederer 2000; Frühwald and Schickhofer 2005). Machine grading is based on density or dynamic modulus of elasticity $\left(\mathrm{MoE}_{\mathrm{dyn}}\right)$ measurement, for which experimental data from tensile/ bending experiments are required. The machine grading of HW is less developed than that of SW, but MOE $\mathrm{dyn}_{\text {data }}$ for grading seems to be well suited for chestnut (Nocetti et al. 2010, 2016), oak (Kretschmann and Green 1999) and eucalyptus (Nocetti et al. 2017) with $\mathrm{R}^{2}$ values between 0.33 and 0.44. $\mathrm{MOE}_{\mathrm{dyn}}$ as a prediction variable is useful, also in case of SW/HW species combination (Ravenshorst 2015). The accuracy of approaches based on tension strength is considerably lower (Green and McDonald 1993; Frühwald and Schickhofer 2005; Van de Kuilen and Torno 2014).

For temperate HWs, the incorporation of visible grading criteria in the machine strength grading improves the strength prediction with $\mathrm{R}^{2}$ values above 0.65 (OliverVillanueva et al. 1996; Frühwald and Schickhofer 2005). However, the accuracy is species specific and can be poor even for the multivariate models, which combine visual and machine parameters ( $\mathrm{R}^{2}$ of 0.33 for chestnut) (Vega et al. 2012). In the case of oak, beech and red maple, the machine measurements were combined with manual knottiness measurement for high quality lamella (Janowiak et al. 1997; Frese and Blaß 2007; Ehrhart et al. 2016b), which resulted in threshold values without compensating the values in a single regression model. The throughput rate of this approach is low. 
In the case of SWs, automated grading machines are able to measure non-visible and visible grading criteria in one step, while multi-sensor systems generally combine knottiness, density and vibration measurement resulting in $R^{2}$ values of 0.69 (Bacher 2008). The common way to detect knottiness is the X-ray attenuation (XRA) measurement (Giudiceandrea 2005). This technique performs well for SW, as knots are twice as dense as the clear wood. For HWs, the difference between the knot and clear wood is low and leads to less accurate knot detection. The studies by Nocetti et al. (2010) on chestnut timber and Nocetti et al. (2017) on eucalyptus show only modest improvements in the case of machine measured knottiness and strength.

For European ash and maple no dedicated grading options are available with respect to glulam application, which is the main focus of this paper. The currently listed mechanical properties are derived from bending tests (Glos and Torno 2008). Therefore, the question arises which mechanical property values in tension can be obtained for visual grading, combined visual and machine grading, and fully automated machine grading? For the machine strength grading, a combined predictor of $\mathrm{MOE}_{\text {dyn }}$ and X-ray knottiness measurement will be considered. Mechanical properties and yields should be optimised for both species. Additionally, the mechanical properties will be compared to the property profiles needed for glulam production according to Kovryga et al. (2016b).

\section{Materials and methods}

To study the mechanical properties of ash (Fraxinus spp.) and maple (Acer spp.) boards, a total of 862 specimens were sampled from Central and Northern Germany (Table S1). The sample for ash included three sub-samples originating from northern Bavaria (BAY) and Thuringia $\left(\mathrm{TH}_{\mathrm{I}}\right.$ and $\mathrm{TH}_{\mathrm{II}}$ ), respectively. The BAY boards were cut from
200 to 600 mm diameter logs with a band saw, while the pith was discarded (Figure 1a). For HWs, a pith-free cutting pattern is preferred, as boards with pith tend to splitting and warping. The average quality of the logs corresponded to $\mathrm{B} / \mathrm{C}$ (common/moderate quality) according to the roundwood standard EN 1316-1. The detailed description of the sawing pattern and log quality is provided by Van de Kuilen and Torno (2014).

The samples from TH were cut to $3 \mathrm{~m}$ boards from 200 to $390 \mathrm{~mm}$ diameter logs. For sample $\mathrm{TH}_{\mathrm{II}}$, the cutting pattern including pith (Figure $1 \mathrm{~b}$ ) was also considered to estimate the possibility of the entire wood utilisation. The quality of logs was on average C (moderate quality) and D (logs not assigned to classes A-C, whereby $40 \%$ of the log's volume is useable) according to the European roundwood standard EN 1316-1. For each of the ash and maple species, both $\mathrm{TH}_{\mathrm{I}}$ and $\mathrm{TH}_{\mathrm{II}}$ ) were considered as a single sample, as the mean static MOE and $5^{\text {th }}$ percentile of tensile strength (TS) differed for the subspecies by $5 \%$ and $6 \%$, respectively. This difference lies within the natural variation for wood species (Stapel and Van de Kuilen 2014).

Visual strength grading: Visual strength grading in Europe is delegated to national grading standards. Here, the German visual grading rules DIN 4074-5:2008 (including ten visual criteria) for boards ("Brett/Bohle") were applied and the knottiness, presence of pith, bark inclusion, wane and fibre deviation were considered. Growth ring width is not included in the standard because it is not relevant for HW species (Oliver-Villanueva et al. 1996; Glos and Lederer 2000; Frühwald and Schickhofer 2005). The main knottiness parameters of the standard are: (1) Single knot (SK) or DIN Einzelast Brett (DEB) is defined as the ratio between the size of the largest knot related to the width of the board (Figure 2a). The size includes dimensions (width parallel to the edge) of an individual knot on all board surfaces. (2) Knot cluster (KC) or DIN Abstandsammlung Brett (DAB) is a multiple knot criterion, which considers all knots appearing in a moving window of $150 \mathrm{~mm}$. Therefore, the spread of all knots over the $150 \mathrm{~mm}$ window is related to the width of the board (Figure $2 \mathrm{~b}$ ). The grading criteria SK and KC are relevant to the grading of boards and lamellas. The low knottiness values indicate small knot size and/or in the case of KC rare occurrence or the knots. (3) Edge knot criterion (E) or Schmalseitenast is an optional criterion for boards used for glulam production and represents the penetration depth of the knots appearing on the edge side only (Figure 2c). For several edge knots,
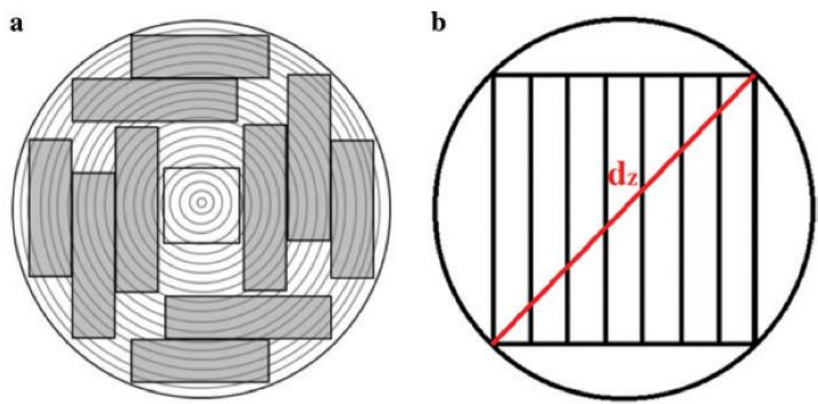

Figure 1: Sawing pattern chosen for the milling of (a) BAY sample (Torno et al. 2013) and (b) TH II sample. In (a) indicative "cutting all around" pattern and in (b) cutting pattern including pith are illustrated. 


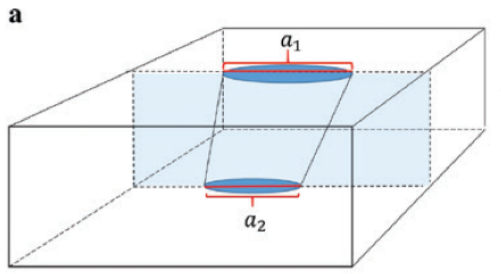

$$
S K=\frac{a_{1}+a_{2}}{2 w}
$$

b
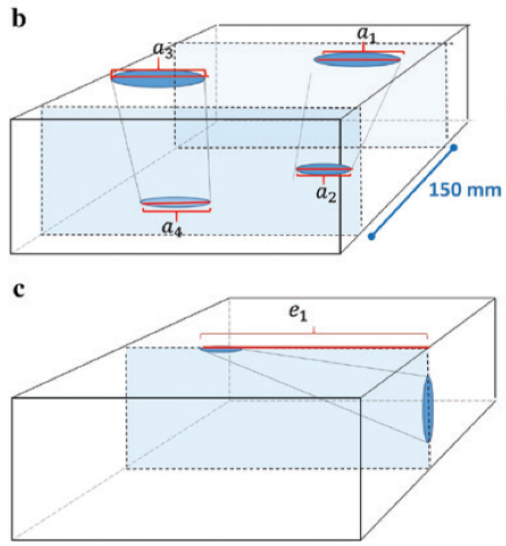

$E=\frac{e_{1}+e_{2}}{w}$

Figure 2: Measuring rules for knots according to grading rules for boards of German visual grading standard DIN 4074-1 and DIN 4074-5.

Figure illustrates different knotiness parameters: (a) SK, Single knot; (b) KC, knot cluster; and (c) E, edge knot.

the non-overlapping penetration within a $150 \mathrm{~mm}$ moving window is considered.

Fibre deviation is defined as an angle with the longitudinal axes of the sawn piece and is measured in \% (grain angle). In this study, visible global fibre deviation was detected on drying checks and, additionally, the surface was assessed qualitatively for fibre deviations exceeding the limits of DIN 4074-5. Specimens exceeding the limits were graded as "reject". In addition, to quantify the fibre deviation and to estimate the possible effect on the grade determining properties, the numerical value of fibre deviation was estimated from the failure pattern after tension tests.

HW boards were assigned to visual grades LS13 (highest quality) to LS7 (lowest quality) based on the thresholds listed in Table 2. To assign a lamella to the visual grade, all boundary values had to be met, otherwise, the specimen was assigned to the next lower grade or rejected.

Machine strength grading: The $\mathrm{MOE}_{\mathrm{dyn}}$ longitudinal to the grain was measured on laboratory equipment by means of a multi-sensor system. MOE ${ }_{\mathrm{dyn}}$ combines the eigenfrequency measurement with density measurement (Eq. 1) and is dependent on the length of the board. The natural frequency from longitudinal oscillation was measured by an accelerometer as well as density. The $\mathrm{R}^{2}$ between laboratory and in a multisensory-system is $99 \%$.

$$
\mathrm{MOE}_{\text {dyn }}=4 \mathrm{f}^{2} 1^{2} \rho
$$

Table 2: Threshold values for grading of hardwood lamellas according to DIN 4074-5:2008.

\begin{tabular}{llll}
\hline Grading property & LS13 & LS10 & LS7 \\
\hline Single knot (SK) (-) & 0.2 & 0.333 & 0.5 \\
Knot cluster (KC) (-) & 0.333 & 0.5 & 0.666 \\
Edge knot (E) (-) & - & - & - \\
Pith (-) & No & No & No \\
Fibre deviation (\%) & 7 & 12 & 16 \\
\hline
\end{tabular}

Machine strength grading was performed on the MiCROTEC (Bressanone/Brixen, IT) GoldenEye 706 scanner. The multi-scanner system combines vibration measurement and X-ray scanning to obtain the $\mathrm{MOE}_{\mathrm{dyn}}$, density and knottiness (Bacher 2008; Giudiceandrea 2005). These parameters can be used either individually or in combination for property prediction. In the latter case, a mathematical model - the so-called indicating property (IP) model - was applied for a better prediction. To predict TS, individual non-linear regression models (Eq. 2) was created, in which the $\mathrm{MOE}_{\text {dyn }}$ and knottiness parameter from the X-ray scan $\left(\mathrm{IP}_{\mathrm{KNOTS}}\right)$ are combined. $\mathrm{IP}_{\text {KNOTS }}$ is a ratio between the number of grid points classified as knots and the overall number of measurement points, both estimated in a $150 \mathrm{~mm}$ window frame. The model parameters were selected based on the finding, that both knottiness and $\mathrm{MOE}_{\mathrm{dyn}}$ show significant ability for timber strength prediction. Visually measured knottiness shows the highest prediction accuracy for strength. Density was included into the model as the overall prediction accuracy increased by 0.03 (Nocetti et al. 2016). For the relationship between knottiness and TS, nonlinear relationship with power of b3 was selected, as the knottiness scatters exponentially to the TS (Figure 5).

$$
\mathrm{IP} f \mathrm{ft}=\mathrm{b}_{1}+\mathrm{b}_{2}\left(\mathrm{IP}_{\mathrm{KNOTS}}\right)^{\mathrm{b} 3}+\mathrm{b} 4 \mathrm{MOE}_{\mathrm{dyn}}+\mathrm{b}_{5} \text { DENS }
$$

The model was fitted to the data by means of the Levenberg-Marquardt nonlinear least squares algorithm implemented in MATLAB Statistics and Machine Learning Toolbox ver. R2016a (Mathworks, Natick, MA, USA). Additionally, separate prediction models for the static modulus of elasticity and density were created:

$$
\mathrm{IP} \mathrm{MOE} \sim \mathrm{MOE}_{\mathrm{dyn}}+\mathrm{IP}_{\mathrm{KNOTS}} \text {; }
$$

IP DENS DENS.

In this case, knottiness improved the prediction accuracy of $\mathrm{MOE}_{\text {stati }}$ significantly by 0.05 .

The three IPs served as benchmarks for the prediction of the grade determining properties (strength, stiffness and density). How ever, for the grading, two IPs [modelled tensile strength (IP ft) and modelled modulus of elasticity (IP MOE)] were considered. Modelled density (IP DENS) was not considered for the strength class assignment. The initial settings were derived separately for ash and maple to test the feasibility of machine grading. All mechanical property value requirements were met (FprEN 14081-2:2017) and were calculated in accordance with EN 14358:2016.

Compared to the procedure of FprEN 14081-2:2017, the verification steps have been skipped and less than four sub-samples were used for settings. Therefore, the settings are approximative to check the grading feasibility for selected species. It should be noted, that the settings are only representative for the growth area (Germany/Central Europe) of ash and maple, dimensions and sawing techniques used. 
Particularly, the timber is sawn from small sized logs (TH) and small to medium-sized logs (BAY) of qualities suitable for sawn wood. However, for the final application in sawmills, the verification procedure is mandatory. The final yields and thresholds may therefore differ.

For the combined method (visual plus machine grading), $\mathrm{MOE}_{\mathrm{dyn}}$ measured in Eq. 1 is combined with the visual assessment of boards with separate thresholds for each of the parameters and without allowing an interaction of the grading parameters in the regression model. This option was suggested by Frese and Blaß (2007) for beech glulam and is recommended in the German technical approval Z-9.1-679 (2013).

Destructive tests: The specimens were tested in tension in accordance with EN 408:2010 and EN 384:2016 with a testing span of 9 times the width. For all specimens, the grade-determining density, MOE and TS properties were measured under the conditions of $20^{\circ} \mathrm{C} / 65 \%$ relative humidity (RH). Density was determined on clear wood specimens as specified by EN 408 (2010). Moisture content (MC) was measured in accordance with EN 13183-1:2002 and was on an average 11\% for each of the species and sub-samples. The MOE and density were adjusted to the reference $\mathrm{MC}$ of $12 \%$ and the TS adjusted to $150 \mathrm{~mm}$ width based on the equations listed in EN 384:2016. The characteristic values were calculated in accordance with EN 14358:2016 nonparametric method.

Optimisation of grading thresholds: Setting grading thresholds for both visual and combined grading is a required step to produce sawn timber with the desired mechanical properties with simultaneous yield maximising. Both higher yield and enhanced mechanical properties are the desired objectives, but these requirements are conflicting, as a higher yield can be obtained only by reducing the mechanical properties ceteris paribus. Therefore, a multi-objective optimisation was applied:

$$
\max \mathrm{F}(\mathrm{x})=\left[\mathrm{f}_{\text {yield }}(\mathrm{x}), \mathrm{f}_{\text {class }}(\mathrm{x})\right],
$$

where $\mathrm{f}_{\text {wit }}$ and $\mathrm{f}_{\text {the }}$ are the objective functions and $\mathrm{x}=\left(\mathrm{x}_{1}, \mathrm{x}_{2} \ldots, \mathrm{x}_{\mathrm{N}}\right)^{\mathrm{T}}$ is the vector of the decision variable, i.e. in our case the grading thresholds. The objective functions calculate the yield and strength class assignment for each combination of grading thresholds.

For problem solutions, the multi-objective optimisation based on evolutionary algorithms, particularly the genetic algorithm NSGAII presented by Deb et al. (2002), was applied. The underlying principle for all evolutionary algorithms is similar, i.e. the extinction of weak and unfit species by natural selection (Konak et al. 2006). Fitter and stronger individuals have a greater chance of passing to the next generation. The application of this algorithm to grading is explained in detail by Kovryga et al. (2016a). Boundary values are optimised for each successive grading class LS13 to LS7, beginning with the highest class. This gives the highest yield and highest strength class for the highest grades.

TS classes: No TS classes are currently listed for HWs in the European strength class systems. The highest TS class for SWs is T30 (characteristic TS $30 \mathrm{MPa}$ ). To study the potential of HW species, the material profiles derived by Kovryga et al. (2016b) were used as a basis. Table 3 shows the material profiles named DT (deciduous TS) classes. As TS classes for HWs begins with the characteristic TS of $18 \mathrm{MPa}$ for the lower valued specimens. In the current study, SW strength classes will also serve for the classification.
Table 3: Selection of TS-classes for softwoods (T-classes, adopted from EN 338 (2016) and proposed TS-classes for hardwoods (DT-classes), adopted from Kovryga et al. (2016b).

\begin{tabular}{lrrr}
\hline & & & Properties \\
\cline { 2 - 4 } Classes & $\mathbf{f}_{\mathrm{t}, 0, \mathrm{k}}(\mathbf{M P a})$ & $\mathbf{E}_{0, \text { mean }}(\mathrm{GPa})$ & $\boldsymbol{\rho}_{\mathbf{k}}\left(\mathbf{k g ~ m}^{-3}\right)$ \\
\hline T-classes for SW & & & \\
T14 & 14 & 11 & 350 \\
T14.5 & 14.5 & 11 & 350 \\
T15 & 15 & 11.5 & 360 \\
T16 & 16 & 11.5 & 370 \\
Prop0sed DT-classes & & & \\
DT18 & 18 & 12 & 550 \\
DT22 & 22 & 13 & 550 \\
DT25 & 25 & 13.5 & 550 \\
DT28 & 28 & 14 & 550 \\
DT30 & 30 & 14.5 & 550 \\
DT34 & 34 & 15 & 610 \\
DT38 & 38 & 15.5 & 610 \\
DT42 & 42 & 16 & 620 \\
DT46 & 46 & 16.5 & 630 \\
DT50 & 50 & 16.5 & 640 \\
DT54 & 54 & 17 & 640 \\
\hline
\end{tabular}

\section{Results and discussion}

\section{Ungraded properties}

Table 4 shows the values for the visible and mechanical properties of ungraded ash and maple boards. For ash, the mechanical properties differ between TH and BAY. The boards from BAY sample show lower TS, $\mathrm{MOE}_{\text {static }}$ and densities compared to the TH sample. The higher values for ash boards are comparable to those for ash boards presented by Frühwald and Schickhofer (2005) as well as for both $5^{\text {th }}$ percentile and mean. Van de Kuilen and Torno (2014) reported higher values, though specimens were tested with reduced testing length.

The ratio between mean density and characteristic density differs between northern Germany and Central Germany growth regions, with the ratio of 1.2, which is specified in EN 384 for SWs and HWs. The coefficient of variation is low for density, particularly in Central Germany. The variation of TS is very high for all specimens and samples (CV > 0.470).

The European maple values are comparable to those of red maple reported by Green and McDonald (1993), who reported mean TS values as high as $62.8 \mathrm{MPa}$ for visually graded timber following standard grading rules (NELMA 1991) based on "select structural" (SS), and $41.3 \mathrm{MPa}$ for grade No. 3, and mean MOE values of $13.0 \mathrm{GPa}$ and 
Table 4: Descriptive statistics of visual and mechanical properties of ash (Fraxinus spp.) and maple (Acer spp.) boards.

\begin{tabular}{llrrr}
\hline & & \multicolumn{3}{r}{ Ash } \\
\cline { 3 - 4 } Parameter & Statistics & BAY & TH & Maple TH \\
\hline $\mathrm{n}$ & & 178 & 303 & 381 \\
$\mathrm{SK}(-)$ & $\mu$ & 0.07 & 0.079 & 0.115 \\
& $\mathrm{CV}[-]$ & 1.450 & 1.135 & 0.992 \\
$\mathrm{KC}(-)$ & $\mu$ & 0.09 & 0.102 & 0.149 \\
& $\mathrm{CV}[-]$ & 1.525 & 1.159 & 1.002 \\
$\mathrm{MOE}_{\text {dyn }}(\mathrm{GPa})$ & $\mu$ & 13.7 & 16.2 & 14.5 \\
& $\mathrm{CV}[-]$ & 0.164 & 0.111 & 0.118 \\
$\rho\left(\mathrm{kg} \mathrm{m}^{-3}\right)$ & $\mu$ & 657 & 701 & 664 \\
& $\mathrm{CV}[-]$ & 0.097 & 0.067 & 0.067 \\
& $\mathrm{Q}_{0.05}$ & 549 & 635 & 569 \\
$\mathrm{MOE}_{\text {static }}(\mathrm{GPa})$ & $\mu$ & 12.7 & 15.6 & 13.8 \\
& $\mathrm{CV}[-]$ & 0.206 & 0.146 & 0.16 \\
$\mathrm{f}_{\mathrm{t}}(\mathrm{MPa})$ & $\mu$ & 52.7 & 67.1 & 53.4 \\
& $\mathrm{CV}[-]$ & 0.470 & 0.487 & 0.490 \\
& $\mathrm{Q}_{0.05}$ & 19.4 & 23.0 & 18.9 \\
\hline & & & & \\
& & &
\end{tabular}

BAY, Bavaria; TH, Thuringia.

11.85 GPa, respectively. The results, however, should be compared with caution due to a possible size effect, as the specimens were tested in tension with a free test duration of $16 \mathrm{~h}$ in the study of Green and McDonald (1993) and only $9 \mathrm{~h}$ in the present study. Maple shows lower tensile and bending properties than ash (Glos and Torno 2008).

\section{Strength grading parameters}

Table S2 shows the type and number of different wood features, with the exception of knots. Overall, a high proportion of boards with pith was observed. The BAY sample contains fewer pith boards compared to $\mathrm{TH}$ samples as in the former the larger log dimensions, combined with a special pith-omitting sawing pattern reduced the relative moiety of the pith. Nevertheless, some stocks of pith boards are present due to stem eccentricity. For some boards, the presence of pith coincides with fibre deviation, thus pith removal also means mitigating fibre deviation.

The cumulative distribution function of TS for ash and maple boards is shown in Figure 3, where visually observable fibre deviation reveals TS values in the lower part of the strength distribution. Specimens showing a visible fibre deviation should be rejected, though the fiber deviation is difficult to quantify (Frühwald and Schickhofer 2005). Rejecting these specimens affects the bottom part of the distribution (Figure 3), and it is a criterion applied by Ehrhart et al. (2016b) for grading of beech boards into classes with TS values of $50 \mathrm{MPa}$.

The pith-containing specimens in lamellas (154 for ash and 137 for maple) show a higher frequency of low-strength values compared to the cumulative frequency distribution of the whole dataset. The mean strength values for the pith-containing boards are of 49.7 and $44.9 \mathrm{MPa}$ for ash and maple, respectively, lower than pith-free boards, with 67.2 and $58.4 \mathrm{MPa}$, respectively. This supports the findings by Glos and Lederer (2000) and Frühwald and Schickhofer (2005) concerning the strength-reducing effect of pith. Nevertheless, strength values of pith-containing specimens range up to $130 \mathrm{MPa}$, with a considerable fraction of test values above $40 \mathrm{MPa}$ (over $50 \%$ for ash and $40 \%$ for maple). Rejecting pith during visual assessment oversimplifies the relationship and leads to lower yields and not necessarily higher strength values. Moreover, other criteria a

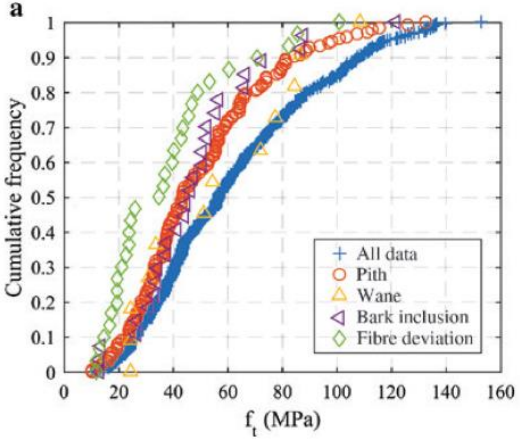

b

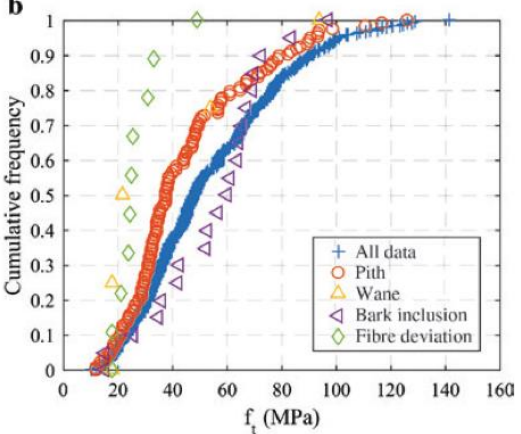

Figure 3: Empirical CDF of tensile strength grouped by defect type for ash (a) and maple (b). For each defect the distribution of tensile strength values is illustrated. 


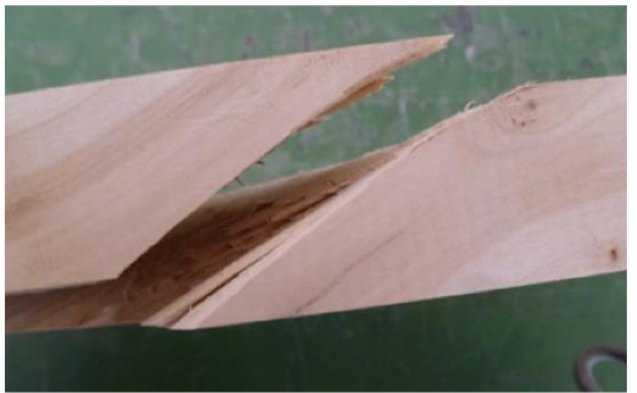

Figure 4: Maple specimen, failure at the slope of grain.

in pith-containing boards, such as knottiness or fibre deviation, also impact strength. For some boards, as can be seen in Table S2, several wood features are significantly overlapping. Figure 4 shows an example of a pith board with failure induced by the grain slope.

There are indicators that pith boards do not affect the properties of glulam, as shown by Janowiak et al. (1997), who found that the quality of the inner and outer log materials are very similar. On the other hand, pith boards tend to have a higher number of splits (Glos and Lederer 2000) and the glulam TS perpendicular to the grain (TS ) is also deteriorated in presence of pith. The study by Hübner (2013) revealed that ash glulam TS differs significantly between boards without and with pith.

Table 5 shows the relationship between grading parameters and TS. Generally, knottiness shows the highest correlation to strength as a single parameter. $\mathrm{R}^{2}$ values over 0.37 for ash and 0.475 for maple are far beyond those obtained for SWs, that range from 0.15 to 0.35 (Denzler et al. 2015). Knot free and boards with small knots are analysed together as will be the case under practical production conditions. Assuming non-linear conditions, even higher $\mathrm{R}^{2}$ values between knot cluster and strength ( 0.466 for ash and 0.588 for maple) can be obtained (Figure 5). In contrast, the impact of the edge knot criterion is low with an $\mathrm{R}^{2}$ of 0.051 , because this criterion is valid only on the edge and not under single

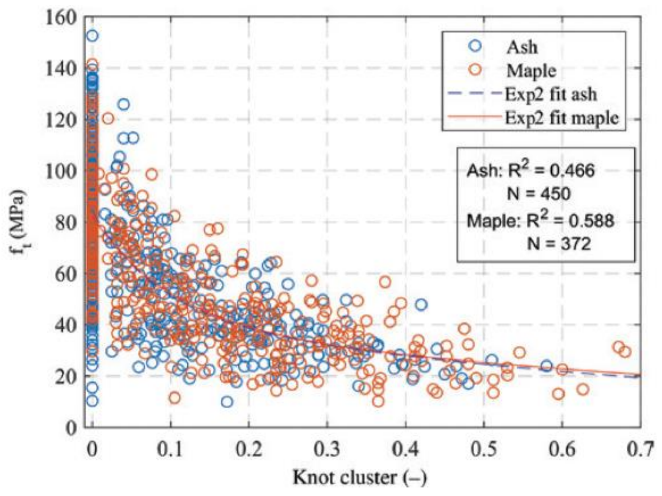

Figure 5: Scatter plot between knot cluster and tensile strength for ash and maple with an exponential fit.

Visible fibre deviation and large bark inclusions are rejected.

Table 5: Coefficient of determination $\left(\mathrm{R}^{2}\right)$ for the prediction of grade-determining properties for ash and maple.

\begin{tabular}{|c|c|c|c|c|c|c|}
\hline \multirow[b]{2}{*}{ Grading parameters } & \multicolumn{3}{|r|}{ Ash } & \multicolumn{3}{|r|}{ Maple } \\
\hline & $\boldsymbol{\rho}_{12}$ & $E_{0}$ & $f_{t, 150}$ & $\boldsymbol{\rho}_{12}$ & $\mathrm{E}_{0}$ & $f_{t, 150}$ \\
\hline \multicolumn{7}{|l|}{ Visual grading } \\
\hline SK (all data) & 0.013 & 0.121 & 0.381 & 0.098 & 0.237 & 0.475 \\
\hline SK (w/o knot free spec.) & 0.000 & 0.217 & 0.334 & 0.068 & 0.222 & 0.403 \\
\hline KC (all data) & 0.007 & 0.119 & 0.377 & 0.087 & 0.208 & 0.461 \\
\hline KC (w/o knot free spec.) & 0.000 & 0.206 & 0.345 & 0.056 & 0.182 & 0.385 \\
\hline E & 0.008 & 0.000 & 0.051 & 0.022 & 0.040 & 0.098 \\
\hline Pith & 0.017 & 0.001 & 0.071 & 0.015 & 0.025 & 0.059 \\
\hline Fibre deviation (after break) & 0.001 & 0.011 & 0.025 & 0.012 & 0.016 & 0.028 \\
\hline Fibre dev. (after break, knot free) & 0.005 & 0.002 & 0.072 & 0.10 & 0.009 & 0.023 \\
\hline \multicolumn{7}{|l|}{ Machine grading } \\
\hline $\mathrm{MOE}_{\text {dyn }}$ & 0.519 & 0.737 & 0.270 & 0.013 & 0.184 & 0.288 \\
\hline $\mathrm{IP}_{\mathrm{KNOTS}}$ & 0.008 & 0.109 & 0.197 & 0.188 & 0.590 & 0.143 \\
\hline IP MOR (logstrength) & 0.113 & 0.603 & 0.484 & 0.024 & 0.441 & 0.485 \\
\hline IP MOR_nlinear & 0.098 & 0.516 & 0.576 & 0.018 & 0.397 & 0.533 \\
\hline IP MOE & 0.519 & 0.786 & 0.315 & 0.114 & 0.641 & 0.251 \\
\hline IP DENS & 0.907 & 0.351 & 0.039 & 0.896 & 0.025 & 0.032 \\
\hline
\end{tabular}


knot and knot cluster conditions. Despite the high correlation of knottiness parameters to TS, a high TS variation for knot-free and low-knottiness specimens $(\mathrm{KC}<0.1)$ is visible (Figure 5). The TS ranges from 10 to $150 \mathrm{MPa}$ and increases the importance of other criteria in addition to knottiness, which does not provide satisfactory strength prediction for high quality material. As shown in Figure 3, pith and larger fibre deviation affects the average quality and the TS values are decreasing in most cases.

The machine grading parameters show medium to high prediction accuracy for both TS and stiffness. Nonlinear grading model improves the strength prediction (Figure 6), i.e. $\mathrm{R}^{2}$ is 0.576 for ash and 0.533 for maple. In this case, machine knottiness does not improve the data based on $\mathrm{MOE}_{\mathrm{dyn}}$ alone ( $\mathrm{R}^{2}$ for ash 0.276 and 0.151 for maple), as $\mathrm{MOE}_{\mathrm{dyn}}$ is estimated over the entire length of the timber piece and lowers the effects the size and position of local defects. The prediction strength of the combined models is lower compared to similar SW models, where $R^{2}$ values of up to 0.69 are usual (Bacher 2008). The low $R^{2}$ values are due to the lower correlation between knottiness and strength of HWs because the algorithm is not optimised for HWs, where the similar densities of clear HW and knots has to be considered (Giudiceandrea 2005).

For both species, density and stiffness are best predicted by the IP DENS and IP MOE, respectively. The measured $\mathrm{R}^{2}$ values between IP MOE and TS are comparable to those reported by Frühwald and Schickhofer (2005) for temperate European HWs and by Green and McDonald (1993) for red maple. Neither IP MOR nor IP MOE provides accurate measurement for density ( $R^{2}$ below 0.1 ), even though density is part of the strength prediction model and included in $\mathrm{MOE}_{\mathrm{dyn}}$ calculations. This behaviour is related to the low correlation between TS and density, which is even negative for maple $(r=-0.180)$, meaning a density decrement for higher strength values. This pattern can be attributed to species-specific characteristics, as density decreases with age for Norway maple and sycamore maple (von Wedel 1966). Outer parts display higher quality in terms of lower knottiness, while at the same time lower density values are measured.

\section{Visual grading}

The optimised thresholds for grading after DIN 4074-5 are presented including the optional knot criteria.

Table S3 shows the grading results according to German visual grading rules. Concerning the yields, the highest grade LS13 accounts for over $50 \%$ of the ash and maple lamellas. Rejects constitute the $2^{\text {nd }}$ highest category. Differences between ash sub-samples are observable. Over $80 \%$ of boards from BAY were assigned to the LS13 grade, whereas lamellas from BAY showed only $10.5 \%$ rejects, and $40.9 \%$ of the lamellas from TH were rejected. The latter is due to a high number of pith containing boards that are generally rejected for HWs by DIN 4074-5 (2008). The pith boards are the result of different sawing patterns chosen. This supports the findings by Glos and Torno (2008) that the quality of HW timber is either high or at a low quality level, and no specimens belongs to medium grades.

In the compilation of Table S4, the properties of LS13 ash differ between sub-samples. Lamellas from BAY have the lowest strength values with $23.8 \mathrm{MPa}$ and MOE values with $12.8 \mathrm{GPa}$, whereas lamellas from $\mathrm{TH}$ dispose of data a

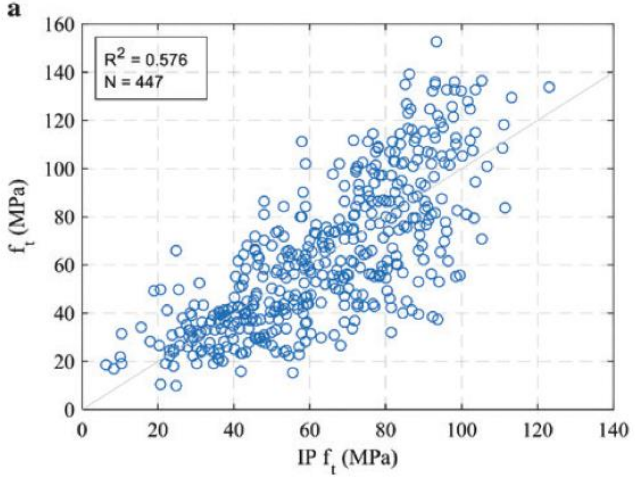

b

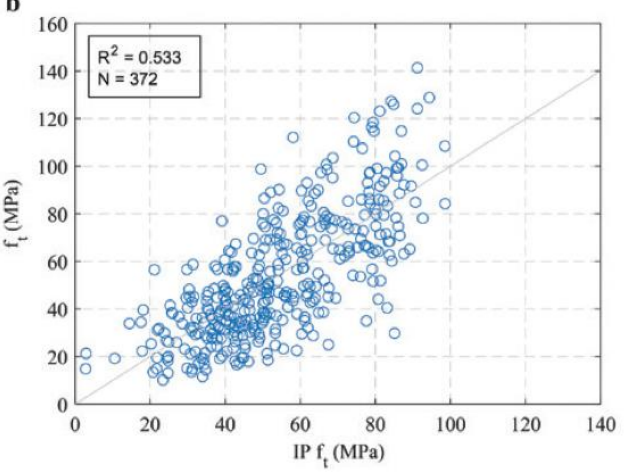

Figure 6: Scatter plot of the relationship between predicted tensile strength IP ft and measured tensile strength of ash (a) and maple (b), graphs are used in conjunction with EN 14081-2 and EN 14358 for the determination of grade thresholds. 
around $36 \mathrm{MPa}$. The strength values for maple assigned to LS13 are with $34 \mathrm{MPa}$ slightly lower than that of ash. The mean MOE for maple is with $14.5 \mathrm{GPa}$, not as high as the one for ash from $\mathrm{TH}$. If the samples are assigned to the strength class profiles proposed by Kovryga et al. (2016b), the ash data exceed the requirements of DT34 for the TH and BAY samples only in case of assignment to DT22. The difference is due to the specimen's origin and partly due to size effects, as the BAY sample specimens include both large and small cross-sections. Large crosssections show lower strength values. No adjustment for specimens with height over $150 \mathrm{~mm}$ to the reference height of $150 \mathrm{~mm}$ is required according to EN 384:2016. For the assignment of LS13, the TS was the grade-limiting property.

Applying the "edge knot criterion" to lamella grading is optional. If a criterion is applied, the yield for the highest grade is reduced only slightly compared to the lamella rules presented above. A maximum of 3.0\% for the TH sample and minimum of $0.6 \%$ for the BAY sample was seen. There is also an effect on TS, which increases slightly by $0.6 \mathrm{MPa}$ for both species. In Figure 7, the scatter plot between edge knot criterion and the TS for timber graded is presented. A high variation in TS for edge knotfree $(E=0)$ timber can be observed. Lamellas containing edge knots show homogenous scatter in TS for increasing edge-knot penetration depth. Thus, TS does not seem to be affected by edge knot size. The low $\mathrm{R}^{2}$ values of 0.05 and 0.098 between edge knot and TS for ash and maple, respectively, supports this conclusion. Stapel and Van de

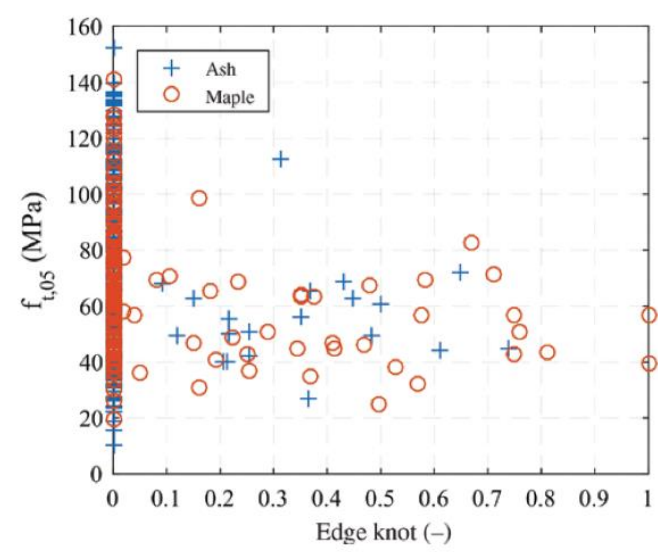

Figure 7: Scatter plot of the relationship between the edge knot criterion as per DIN 4074-5 and tensile strength for specimens assigned to LS13 of DIN4074-5 (2008), without considering the edge knot criterion.
Kuilen (2014) showed the limited significance of the edge knot criterion for tension loaded spruce boards. The edge knot criterion, however, is mandatory if boards are used for flatwise bending applications.

The grading boundaries were optimised aimed at increasing the mechanical properties and yields and also for selection of easily applicable parameters (Table 6). Solution A represents grading to the highest possible strength class (DT34 in this case), while solution B is used to benchmark the visual grading. Grading to DT34 allows for higher mechanical properties at the expense of lower yields. In this case, density requirements are not considered. If graded to DT30, 10\% higher yields can be achieved compared to visual grading. With the selected precision of optimisation steps (0.1), grading to DT28 was not possible. Smaller changes in the knottiness boundary values would make grading less robust because the actual knot measurement is vulnerable to the human estimates error. Regarding the grading thresholds, one should keep in mind that thresholds of 0 are a numerical value, as knots below $5 \mathrm{~mm}$ are not considered.

For maple, visual grading to DT30 is possible. Compared to visual grading as per DIN 4074-5 (2008), no higher strength class assignment is possible. Solution A represents grading to the same grade as visual strength grading: In this case, the yield is 5\% higher and the remaining timber can be utilised as T14. A possible application for the low-grade lamellas would be the inner part of glulam beams. Solution B represents grading to a lower strength class (DT28). In this case, $22.8 \%$ higher yields are possible.

The grading results show the high potential of visually graded ash and maple lamellas for glulam production, especially compared to SW lamellas. Machine-graded spruce can be assigned to T30 $\left(\mathrm{f}_{\mathrm{t}, 0, \mathrm{k}}=30 \mathrm{MPa}\right.$ and $\mathrm{E}_{0, \text { mean }}=15.5 \mathrm{GPa}$ ). Based on the result by Stapel and Van de Kuilen (2014), visually graded spruce can be assigned to T22. Yields of only $20 \%$ are likely. The high yield of HWs at the highest grade levels are attractive. However, from the economic feasibility point of view, the yield from log to lamellas is a more accurate indicator. For HWs, higher volumetric losses occur during processing (e.g. due to sawing and shrinkage losses).

\section{Combined visual and machine strength grading}

Combined visual and machine grading improves the results. The edge knot criterion was not included in the optimisation procedure due to the marginal effect on TS. Optimisation with an edge knot allowed only for slightly 
Table 6: Optimised visual grading threshold values and mechanical properties for ash and maple.

\begin{tabular}{|c|c|c|c|c|c|c|c|c|c|}
\hline \multirow{2}{*}{$\begin{array}{l}\text { Wood, } \\
\text { solution }\end{array}$} & \multirow[b]{2}{*}{ Grade } & \multirow[b]{2}{*}{ SK (-) } & \multicolumn{2}{|c|}{ Threshold values } & \multirow[b]{2}{*}{$\rho_{\mathrm{k}}\left(\mathrm{kg} \mathrm{m}^{-3}\right)$} & \multicolumn{2}{|c|}{ Characteristic values } & \multirow{2}{*}{$\begin{array}{l}\text { Tensile } \\
\text { class }\end{array}$} & \multirow[b]{2}{*}{ Yield (\%) } \\
\hline & & & KC (-) & Pith & & $\mathrm{E}_{0, \text { mean }}(\mathrm{GPa})$ & $f_{t, 0, k}(M P a)$ & & \\
\hline \multicolumn{10}{|l|}{ Ash } \\
\hline \multirow[t]{4}{*}{ DIN } & LS13 & 0.2 & 0.333 & No & 559 & 14.9 & 28.7 & DT28 & 61.3 \\
\hline & LS10 & 0.333 & 0.5 & No & 625 & 12.3 & 17.6 & T16 & 7.1 \\
\hline & $\mathrm{LS7}^{\mathrm{a}}$ & 0.5 & 0.666 & No & 596 & 10.2 & 15.3 & T13 & 1.1 \\
\hline & Rej & & & & & & & & 30.4 \\
\hline \multirow[t]{4}{*}{ A } & LS13 & 0 & 0 & Yes & $549^{b}$ & 15.0 & 36.8 & DT34 & 43.8 \\
\hline & LS10 & 0.1 & 0.3 & yes & 596 & 15.0 & 27.9 & DT25 & 27.6 \\
\hline & LS7 & 0.4 & 0.6 & Yes & 609 & 13.5 & 18.1 & DT18 & 28.4 \\
\hline & Rej & & & & & & & & 0.2 \\
\hline \multirow[t]{3}{*}{ B } & LS13 & 0.1 & 0.3 & Yes & 570 & 15.1 & 30.7 & DT30 & 71.3 \\
\hline & LS10 & 0.4 & 0.6 & Yes & 610 & 13.4 & 18 & DT18 & 28.4 \\
\hline & Rej & & & & & & & & 0.2 \\
\hline \multicolumn{10}{|l|}{ Maple } \\
\hline \multirow[t]{4}{*}{ DIN } & LS13 & 0.2 & 0.333 & No & $546^{b}$ & 14.5 & 34 & DT30 & 50.3 \\
\hline & LS10 & 0.333 & 0.5 & No & 616 & 12.6 & 14.9 & T14 & 9.7 \\
\hline & LS7 & 0.5 & 0.666 & No & 620 & 11.0 & 11.9 & - & 3.8 \\
\hline & Rej & & & & 588 & 13.2 & 16 & - & 36.3 \\
\hline \multirow[t]{3}{*}{ A } & LS13 & 0.1 & 0.3 & Yes & $546^{b}$ & 14.6 & 32.1 & DT30 & 55.4 \\
\hline & LS10 & 0.6 & 0.8 & Yes & 611 & 12.6 & 14 & T14 & 44.6 \\
\hline & Rej & & & & & & & & 0.0 \\
\hline \multirow[t]{3}{*}{ B } & LS13 & 0.2 & 0.3 & Yes & 555 & 14.3 & 28.4 & DT28 & 73.1 \\
\hline & LS10 & 0.4 & 0.5 & Yes & 614 & 12.4 & 15.1 & T15 & 22.6 \\
\hline & Rej & & & & & & & & 0.2 \\
\hline
\end{tabular}

${ }^{a} \mathrm{n}<40$. Characteristic properties calculated using parametric method of EN 14358 (2016). ${ }^{b}$ Characteristic density does not match the requirements of the strength class.

higher yields in the higher classes. Thresholds for assigning ash lamellas to the characteristic TS of $62 \mathrm{MPa}$ are possible, though yields are low (11\%). Combinations with yields above $20 \%$ are more beneficial as enough volume for production is available. Compared to ash, maple with a TS of up to $42 \mathrm{MPa}$ is possible. Table 7 shows the selected optimal boundary combinations. For ash, combination A (solution "A") gives an economically attractive yield (23\%) and good properties (DT54). Solution "B" shows the thresholds for assigning the highest grade to DT38. This currently appears to be the most efficient solution. As for ash, in combination with the best available gluing systems, a characteristic finger-joint tension strength of up to $35.1 \mathrm{MPa}$ can be achieved (Van de Kuilen and Torno 2014). Over 56.4\% of the specimens is suitable for the highest grade. Solution "C" is a benchmark performance of visual grading in terms of yield. In this case, higher yields (74.9\%) can be achieved than in case of visual grading (61.3\%). The yields are slightly higher than the ones based on optimised visual grading $(71.3 \%)$. The characteristic property values match the TS class profiles for HWs.

The mechanical properties of maple are inferior to those of ash. The highest possible strength class assignment is DT42 grading (Table 7, solution A). For all strength classes, the characteristic properties fit the required values, with the exception of density, and all values should be elevated for a higher strength class assignment. Grading to DT38 allows assigning to the $2^{\text {nd }}$ lowest grade to DT25, with yields almost equally distributed between the grades.

The coefficient of variation (CV) for combined grading is lower than for visual grading, falling in the case of the TS of DT54 ash below 0.27 and 0.09-0.1 for the characteristic $\mathrm{MOE}_{\text {static }}$. For maple, the $\mathrm{CV}$ of $\mathrm{MOE}_{\text {static }}$ is even lower (0.08-0.09). For both species, the lowest class can be assigned to grades T15/T16 and DT18, respectively. The obtained properties of lower grade samples are comparable to those of red maple glulam inner laminations (Janowiak et al. 1997).

The optimised thresholds for grading by the combined approach tolerates the presence of pith. All parameter combinations are successful with the exception for grading to DT54 (solution "A") for ash. For achieving TS values below $54 \mathrm{MPa}$, the pith criterion seems to be less important. The observation for the pith criterion on the CDF of TS in section "Strength grading parameters" reinforces this conclusion. A separate analysis for the effect of pith on the properties of glulam is required. Density 
Table 7: Grading thresholds and mechanical properties for combined visual and machine strength grading of ash and maple boards.

\begin{tabular}{|c|c|c|c|c|c|c|c|c|c|c|c|}
\hline \multirow{2}{*}{$\begin{array}{l}\text { Species, } \\
\text { solution }\end{array}$} & \multirow[b]{2}{*}{ Grade } & \multicolumn{5}{|c|}{ Threshold values } & \multicolumn{3}{|c|}{ Characteristic values } & \multirow{2}{*}{$\begin{array}{l}\text { Tensile } \\
\text { Class }\end{array}$} & \multirow[b]{2}{*}{ Yield (\%) } \\
\hline & & SK (-) & KC (-) & $E(-)$ & Pith & $\mathrm{E}_{\mathrm{dyn}}(\mathrm{GPa})$ & $\rho_{k}\left(\mathrm{~kg} \mathrm{~m}^{-3}\right)$ & $\mathrm{E}_{0, \text { mean }}(\mathrm{GPa})$ & $\mathrm{f}_{\mathrm{t}, 0, \mathrm{k}}(\mathrm{MPa})$ & & \\
\hline \multicolumn{12}{|l|}{ Ash } \\
\hline \multirow[t]{4}{*}{$A$} & 1 & 0 & 0 & - & No & 15.7 & 641 & 17.1 & 57.5 & DT54 & 23.1 \\
\hline & 2 & 0.1 & 0.1 & - & Yes & 13.4 & 624 & 15.9 & 34.4 & DT34 & 32.9 \\
\hline & 3 & 0.5 & 0.6 & - & Yes & - & $545^{a}$ & 12.7 & 18.2 & DT18 & 44.0 \\
\hline & Rej & & & & & & & & & & 0.0 \\
\hline \multirow[t]{3}{*}{ B } & 1 & 0.1 & 0.1 & - & Yes & 13.1 & 629 & 16.0 & 38.4 & DT38 & 56.4 \\
\hline & 2 & 0.5 & 0.6 & - & Yes & - & $545^{a}$ & 12.8 & 18.2 & DT18 & 43.6 \\
\hline & Rej & & & & & & & & & & 0.0 \\
\hline \multirow[t]{3}{*}{$\mathrm{C}$} & 1 & 0.2 & 0.4 & - & Yes & 13.1 & 624 & 15.5 & 30.2 & DT30 & 74.9 \\
\hline & 2 & 0.4 & 0.6 & - & Yes & 8.3 & 525 & 11.5 & 16.3 & T16 & 24.4 \\
\hline & Rej & & & & & & & & & & 0.2 \\
\hline \multicolumn{12}{|l|}{ Maple } \\
\hline \multirow[t]{4}{*}{ A } & 1 & 0.1 & 0.1 & - & Yes & 15.0 & 617 & 16.0 & 42.1 & DT42 & 24.2 \\
\hline & 2 & 0.2 & 0.2 & - & Yes & 13.0 & 605 & 14.0 & 28 & DT28 & 34.7 \\
\hline & 3 & 0.3 & 0.6 & - & Yes & - & 532 & 12.5 & 16.3 & T16 & 32.8 \\
\hline & Rej & & & & & & & & & & 8.3 \\
\hline \multirow[t]{4}{*}{ B } & 1 & 0.1 & 0.1 & - & Yes & 13.9 & $613^{a}$ & 15.5 & 41.3 & DT38 & 37.1 \\
\hline & 2 & 0.2 & 0.5 & - & Yes & 12.2 & 601 & 13.5 & 25.2 & DT25 & 33.6 \\
\hline & 3 & 0.3 & 0.6 & - & Yes & 10.9 & 539 & 12.4 & 15.2 & T15 & 18.5 \\
\hline & Rej & & & & & & & & & & 8.1 \\
\hline \multirow[t]{3}{*}{ C } & 1 & 0.2 & 0.3 & - & Yes & 12.0 & 608 & 14.6 & 30.2 & DT30 & 62.9 \\
\hline & 2 & 0.4 & 0.5 & - & Yes & - & 527 & 12.3 & 15.8 & T15 & 32.8 \\
\hline & Rej & & & & & & & & & & 4.3 \\
\hline
\end{tabular}

aCharacteristic density does not match the requirements of the strength class.

requirements were not considered strictly, as the values deviated from the ones specified in the profiles by less than $5 \mathrm{~kg} \mathrm{~m}^{-3}$. Assigning the specimens to lower grades based on density appears to be inefficient.

\section{Machine strength grading}

Three combinations for (a) grading to the highest strength class, (b) grading to the maximum possible finger-joint strength, and (c) grading to the highest possible visual grade are presented below. Table 8 shows the properties and yields for grading to the selected class combinations. For ash, grading to DT54-DT34-DT18 shows only low yields for the highest grade DT54 (9.2\%) and higher yields to DT34 and DT18. Machine grading to DT50-DT34-DT18 appears more reasonable, as yields of approximately $15.7 \%$ and a characteristic strength of $51.8 \mathrm{MPa}$ can be obtained. The DT38-DT18 combination also shows promising results. For finger-joints, strength of $35 \mathrm{MPa}$ (Van de Kuilen and Torno 2014) and yields around 55\% can be obtained in the grade DT38. For grading to DT30, yields up to $71.8 \%$ are possible. The characteristic property values match the profiles. Nevertheless, the characteristic density does not match the property profiles (Table 3) in each case. For maple, the highest possible strength class achieved is DT42 (DT42-DT28-DT18) with yields up to 10 $\%$. For grade DT38 - with TS data corresponding to the maximum finger-joint TS - a higher yield of 38\% can be achieved (lower than for ash). Grading to DT30 allows for yields slightly above $50 \%$. Machine grading, allows only low yields around $10 \%$ at the highest grade levels (ash graded to DT 54 and maple graded to DT42). The low yields are caused by the high variation in strength for the higher IP values (higher variation of residuals). In this case, characteristic strength calculated according to EN14358:2016 is decreased by the calculation procedure because of the high variation. Obviously, machine grading is better than the visual one, which also allows for grading to higher classes. Strength values above $28 \mathrm{MPa}$ is substantial for machine-graded HW lamellas, especially when compared to visual strength grading. Thus, for ash machine-graded to DT30, the yields are $10.5 \%$ higher than that of ash lamellas visually graded to S13 (DT30). For maple, machine grading yields are 6.3\% higher.

For the highest grades, DT54 for ash and DT42 for maple, the yields for machine grading are twice as low 
Table 8: Grading IP thresholds and mechanical properties of ash and maple boards graded using non-linear IP ft model.

\begin{tabular}{|c|c|c|c|c|c|c|c|c|}
\hline \multirow[b]{2}{*}{ Grading class comb. } & \multirow[b]{2}{*}{ Strength class } & \multirow[b]{2}{*}{$\mathrm{n}$} & \multirow[b]{2}{*}{$I P f_{t} \mathrm{MPa}$} & Thresholds & \multicolumn{3}{|c|}{ Characteristic values } & \multirow[b]{2}{*}{ Yield (\%) } \\
\hline & & & & IP MOE (GPa) & $\rho_{\mathrm{k}}\left(\mathrm{kg} \mathrm{m}^{-3}\right)$ & $E_{0, \text { mean }}(G P a)$ & $f_{t, 0, k}(M P a)$ & \\
\hline \multicolumn{9}{|l|}{ Ash } \\
\hline \multirow[t]{4}{*}{ DT54-DT34-DT18-Rej } & DT54 & 41 & 94.3 & 16.4 & 645 & 18.1 & 54.6 & 9.2 \\
\hline & DT34 & 226 & 54.5 & 9.8 & $607^{a}$ & 15.5 & 34.1 & 50.6 \\
\hline & DT18 & 180 & 6.4 & 7.4 & $545^{a}$ & 12.7 & 18.1 & 40.3 \\
\hline & & & & & & & & 0 \\
\hline \multirow[t]{4}{*}{ DT50-DT34-DT18-Rej } & DT50 & 70 & 88.6 & 15.9 & 643 & 17.7 & 51.8 & 15.7 \\
\hline & DT34 & 196 & 57.3 & 10.1 & $568^{\mathrm{a}}$ & 15.1 & 34.4 & 43.8 \\
\hline & DT18 & 181 & 6.4 & 7.4 & 568 & 12.9 & 18 & 40.5 \\
\hline & & & & & & & & 0 \\
\hline \multirow[t]{3}{*}{ DT38-DT18-Rej } & DT38 & 246 & 58.8 & 10.1 & 620 & 16.1 & 38.3 & 55.0 \\
\hline & DT18 & 201 & 6.4 & 7.4 & $546^{\mathrm{a}}$ & 12.9 & 18.1 & 45.0 \\
\hline & & & & & & & & 0 \\
\hline \multirow[t]{3}{*}{ DT30-T16-Rej } & DT30 & 321 & 47.4 & 8.9 & 575 & 15.6 & 30.1 & 71.4 \\
\hline & T16 & 126 & 6.4 & 7.4 & 565 & 12.2 & 17.7 & 28.6 \\
\hline \multirow{2}{*}{\multicolumn{9}{|c|}{ Maple }} \\
\hline & & & & & & & & \\
\hline \multirow[t]{4}{*}{ DT42-DT28-DT18 } & DT42 & 39 & 64.7 & 15.4 & $609^{\mathrm{a}}$ & 16.5 & 43.6 & 10.5 \\
\hline & DT28 & 192 & 46.2 & 8.7 & 554 & 14.2 & 28.1 & 51.6 \\
\hline & DT18 & 97 & 32 & 7.7 & 591 & 12.6 & 16.1 & 26.1 \\
\hline & & & & & & & & 11.8 \\
\hline \multirow[t]{4}{*}{ DT38-DT25-DT15-Rej } & DT38 & 110 & 63.7 & 11.7 & $605^{a}$ & 15.5 & 38.3 & 29.3 \\
\hline & DT25 & 119 & 46.2 & 9.3 & 602 & 14.1 & 25 & 30.9 \\
\hline & T15 & 128 & 23.7 & 6.4 & 532 & 12.4 & 15.5 & 34.4 \\
\hline & & & & & & & & 5.4 \\
\hline \multirow[t]{3}{*}{ DT30-DT16-Rej } & DT30 & 210 & 49.5 & 8.7 & 560 & 14.7 & 30.1 & 56.5 \\
\hline & T16 & 140 & 25.1 & 6.4 & 573 & 12.7 & 16.1 & 37.6 \\
\hline & & & & & & & & 5.9 \\
\hline
\end{tabular}

${ }^{a}$ Characteristic density does not match the requirements of the strength class.

(over 10\% differences) than the ones using a combined grading approach. For lower grades, however, such as DT38 for ash, machine-graded yields are at $55 \%$, only slightly lower than the combined yields graded to DT38 (56.4\%). For maple graded to DT38, the difference is slightly larger. Machine grading leads to $7.4 \%$ lower yields than the combined grading approach.

The high yields to DT54 for ash and DT42 for maple is attractive for producing premium products with high mechanical properties. In the case of machine-grading, higher throughput rates are possible, though it is not as attractive as in case of the combined grading approach. Improvements in machine strength grading prediction discussed earlier would increase efficiency of grading machines. To utilise material properties efficiently, a reliable finger-joint connection is required. Machine grading to class combinations containing DT34 and/or DT38 appears interesting. The yield for the strength class is only a few percent lower compared to the combined grading approach. In this case, higher processing speed and, thus, higher production volume is likely to compensate for the lower grading yields.

\section{Strength class profiles}

Figures S1 and S2 summarise all property data for the class combinations and grading methods compared to the TS profiles for HWs according to Kovryga et al. (2016b) and the profiles for SW (T-classes) as per EN 338:2016. Generally, for high-quality lamellas with strength $>28 \mathrm{MPa}$, the properties for visual and machine grading methods match the profiles. Though for ash the MOE appears to be undervalued, the scatter of MOE values for the same strength grade reaches the profiles. Thus, for DT34, the MOE ranges between 15 and $16 \mathrm{GPa}$.

For samples assigned to grades below DT22, the empirically estimated MOE exceeds the values of the 
proposed DT-classes. Therefore, by assigning the samples to DT classes with lower MOE values, the actual MOE is undervalued. Due to the low correlation between knottiness and MOE, visual grading does not permit sufficient distinction between MOE values.

For machine-graded timber, the characteristic MOE values exceed the profiles (Table 3 ) due to the grading procedure itself and to the assumptions made for the strength profile definitions (Kovryga et al. 2016b). For machine grading, in addition to the IP $\mathrm{f}_{t}$ a separate IP for stiffness is used, allowing a higher stiffness prediction compared to grading based on a single IP or to visual grading. Moreover, the $\mathrm{HW}$ profiles for TS $>30 \mathrm{MPa}$ are based on the model of visually determined knottiness and $\mathrm{MOE}_{\mathrm{dyn}}$ that show higher strength prediction accuracy $\left(\mathrm{R}^{2}=0.56\right)$ and lower stiffness prediction accuracy $\left(R^{2}=0.59\right)$ compared to the data presented here (Table 5).

\section{Conclusions}

Visual grading in accordance with German visual grading standard DIN 4074-5 (2008) allows for high tensile properties for the highest grades resulting in TS of up to $30 \mathrm{MPa}$, which is achieved for machine graded SW timber as a maximum. Higher mechanical properties can be achieved via combined visual and machine strength grading, as well as via fully automated grading. If grading HW timber by the combined approach for ash, a characteristic TS of $62 \mathrm{MPa}$ is possible, and $42 \mathrm{MPa}$ for maple. Automated grading systems based on combination of MOE and X-ray knot detection allows increasing the prediction accuracy to 0.576 for ash and to 0.533 for maple compared to the $\mathrm{MOE}_{\mathrm{dyn}}$ strength prediction. Compared to the combined grading, lower yields are achieved via grading to classes with superior characteristic property values ( $>50 \mathrm{MPa}$ for ash). The graded lamellas show good agreement with the material profiles proposed by Kovryga et al. (2016b). These profiles reflect $\mathrm{MOE}_{\text {static }}$ values better than the profiles of SW-T-classes for the highest grades obtained by visually grading or by combined grading of boards. However, for visually graded timber to lower grades (e.g. LS10) and machine-graded timber, the actual $\mathrm{MOE}_{\text {static }}$ values are underestimated. The "pith" parameter has little impact on TS properties parallel to the grain during grading. Rejecting the pith allowed only for grading to higher strength classes resulting in strength $>54 \mathrm{MPa}$. For classes with lower property values, the pith may be present in the boards leading to higher yields. Pith is not detrimental in boards applied for glulam beams, if the desired mechanical properties of the final glulam product remain unaffected. The use of the edge knot criterion does not affect the TS properties of the boards in a meaningful way and as such, it can be excluded for grading of tensile loaded boards.

Author contributions: All the authors have accepted responsibility for the entire content of this submitted manuscript and approved submission.

Research funding: This research was supported by the German Federal Ministry of Food and Agriculture (BMEL); Funder Id: 10.13039/501100005908, grant no.: FKZ 22011913.

Employment or leadership: None declared.

Honorarium: None declared.

\section{References}

Aicher, S., Reinhardt, H.-W. (2007) Delaminierungseigenschaften und Scherfestigkeiten von verklebten rotkernigen Buchenholzlamellen [Delamination properties and shear strength of glued beech wood laminations with red heartwood]. Eur. J. Wood Prod. 65:125-136.

Aicher, S., Stapf, G. (2014) Glulam from European white oak: finger joint influence on bending size effect. In: Materials and Joints in Timber Structures. Recent Developments of Technology; RILEM Book series, Vol. 9. Eds. Aicher, S., Reinhardt, H.-W., Garrecht, H. Springer, Dordrecht, The Netherlands. pp. 641-656.

Aicher, S., Christian, Z., Dill-Langer, G. (2014) Hardwood Glulams Emerging Timber Products of Superior Mechanical Properties. In: Proceeding of WCTE 2014, Quebec City, Canada. August $10-14$.

Ammann, S., Schlegel, S., Beyer, M., Aehlig, K., Lehmann, M., Jung, H., Niemz, P. (2016) Quality assessment of glued ash wood for construction engineering. Eur. J. Wood Prod. 74:67-74.

Bacher, M. (2008) Comparison of different machine strength grading principles. In: Proceedings of Conference COST E53, 29-30 October, Delft, The Netherlands.

Bundesministerium für Ernährung und Landwirtschaft (BMEL). (2015) Der Wald in Deutschland - Ausgewählte Ergebnisse der dritten Bundeswaldinventur [The Forests in Germany Selected Results of the Third National Forest Inventory]. BMEL, Bonn, Germany.

Deb, K., Pratap, A., Agarwal, S., Meyarivan, T. (2002) A fast and elitist multiobjective genetic algorithm: NSGA-II. IEEE Trans. Evolut. Computat. 6:182-197.

Denzler, J., Diebold, R., Glos, P. (2015) Machine strength grading - commercially used grading machines - current developments. In: Proceedings of the $14^{\text {th }}$ International Symposium on Nondestructive Testing of Wood, Hannover, Germany. pp. 9-16.

DIN 4074-5. (2008) Strength grading of wood - Part 5: Sawn hardwood. DIN, Berlin. 
Ehrhart, T., Fink, G., Steiger, R., Frangi, A. (2016a) Experimental investigation of tensile strength and stiffness indicators regarding European beech timber. In: Proceeding of WCTE 2016, Vienna, Austria. August 23-25. TU Verlag, Vienna.

Ehrhart, T., Fink, G., Steiger, R., Frangi, A. (2016b) Strength grading of European beech lamellas for the production of GLT and CLT. In: Proceedings of $49^{\text {th }}$ INTER and CIB Meeting, Graz, Austria.

EN 13183-1. (2002) Moisture contentof a piece of sawn timber - Part 1: Determination by oven dry method. CEN European Committee for Standardization, Brussels.

EN 408. (2010) Timber structures - structural timber and glued laminated timber - determination of some physical and mechanical properties. CEN European Committee for Standardization, Brussels.

EN 14358. (2016) Timber structures - calculation of characteristic 5-percentile and mean values for the purpose of initial type testing and factory production control. CEN European Committee for Standardization, Brussels.

EN 338. (2016) Structural timber - Strength classes. CEN European Committee for Standardization, Brussels.

EN 384. (2016) Structural timber - Determination of characteristic values of mechanical properties and density. CEN European Committee for Standardization, Brussels.

FprEN 14081-2. (2017) Timber structures - Strength graded structural timber with rectangular cross section - Part 2: Machine grading; additional requirements for initial type testing. CEN European Committee for Standardization, Brussels.

Frese, M., Blaß, H.J. (2007) Characteristic bending strength of beech glulam. Mater. Struct. 40:3-13.

Frühwald, K., Schickhofer, G. (2005) Strength grading of hardwoods. $14^{\text {th }}$ International Symposium on Nondestructive Testing of Wood, Hannover. pp. 198-210.

Giudiceandrea, F. (2005) Stress grading lumber by a combination of vibration stress waves and X-ray scanning. In: $11^{\text {th }}$ International Conference on Scanning Technology and Process Optimization in the Wood Industry (ScanTech 2005), Las Vegas, NV, USA. pp. 99-108.

Glos, P., Lederer, B. (2000) Sortierung von Buchen- und Eichenschnittholz nach der Tragfähigkeit und Bestimmung der zugehörigen Festigkeits- und Steifigkeitskennwerte [Strength grading of beech and oak timber and derivation of strength and stiffness property values]. Report Nr. 98508. TU München, München, $125 \mathrm{pp}$.

Glos, P., Torno, S. (2008) Allocation of domestic maple, ash and poplar species into the European Standard EN 1912 Structural timbe - strength classes - assignment of visual grades and species. (in German.) 06517 B. TU München, München.

Green, D.W., McDonald, K.A. (1993) Mechanical properties of red maple structural lumber. Wood Fibre Sci. 25:365-374.

Hübner, U. (2013) Mechanische Kenngrößen von Buchen-, Eschenund Robinienholz für lastabtragende Bauteile: Dissertation. Technische Universität Graz, 424 pp.

Janowiak, J.J., Manbeck, H.B., Hernandez, R.H., Moody, R.C. (1997) Red maple lumber resources for glue-laminated timber beams. Forest Prod. J. 47:55-64.

Jeitler, G., Augustin, M., Schickhofer, G. (2016) BIRCH | GLT\&CLT: mechanical properties of glued laminated timber and cross laminated timber produced with the wood species birch. In: Proceeding of WCTE 2016, Vienna, Austria. August 23-25. TU Verlag, Vienna.
Knorz, M., Schmidt, M., Torno, S., van de Kuilen, J.-W. (2014) Structural bonding of ash (Fraxinus excelsior L.): resistance to delamination and performance in shearing tests. Eur. J. Wood Prod. 72:297-309.

Kolling, C. (2007) Klimmahüllen für 27 Waldbaumarten [Climate shells for 27 forest tree specimens]. AFZ-DerWald: 1242-1245.

Kollmann, F.F.P., Côté, W.A. Principles of Wood Science and Technology: I. Solid wood. Springer-Verlag, Berlin, 1968.

Konak, A., David, W.C., Alice, E.S. (2006) Multi-objective optimization using genetic algorithms: A tutorial. Reliab. Eng. Sys. Safe. 91:992-1007.

Konnerth, J., Kluge, M., Schweizer, G., Miljković, M., Gindl-Altmutter, W. (2016) Survey of selected adhesive bonding properties of nine European softwood and hardwood species. Eur. J. Wood Prod. 74:809-819.

Kovryga, A., Stapel, P., van de Kuilen, J.W.G. (2016a) Optimizing characteristic properties of visually graded soft- and hardwoods lamellas for the glulam production. In: Proceeding of WCTE 2016, Vienna, Austria. August 23-25. TU Verlag, Vienna.

Kovryga, A., Stapel, P., van de Kuilen, J.W.G. (2016b) Tensile strength classes for hardwoods. In: Proceedings of $49^{\text {th }}$ INTER and CIB Meeting, Graz, Austria.

Kretschmann, D.E., Green, D.W. (1999) Mechanical grading of oak timbers. J. Mater. Civ. Eng. 11:91-97.

Luedtke, J., Amen, C., van Ofen, A., Lehringer, C. (2015) 1C-PURbonded hardwoods for engineered wood products: influence of selected processing parameters. Eur. J. Wood Prod. 73:167-178.

Manbeck, H.B., Janowiak, J.J., Blankenhorn, P.R., Labosky, P., Moody, R.C., Hernandez, R. (1993) Performance of red maple glulam timber beams. Res. Pap. FPL-RP-519. U.S. Department of Agriculture, Forest Service, Forest Products Laboratory, Madison, WI, 33 pp.

Nocetti, M., Bacher, M., Brunetti, M., Crivellaro, A., van de Kuilen, J.W.G. (2010) Machine grading of Italian structural timber: preliminary results on different wood species. In: Proceeding of WCTE 2010, Riva del Garda, Trento, Italy. June 20-24.

Nocetti, M., Brunetti, M., Bacher, M. (2016) Efficiency of the machine grading of chestnut structural timber: prediction of strength classes by dry and wet measurements. Mater. Struct. 49:4439-4450.

Nocetti, M., Pröller, M., Brunetti, M., Dowse, G., Wessels, C (2017) Investigating the potential of strength grading green Eucalyptus grandis lumber using multi-sensor technology. BioResources 12:9273-9286.

Oliver-Villanueva, J.-V., Quer, M., Becker, G. (1996) Influence of structural parameters on the nondestructive evaluation of ash timber (Fraxinus excelsior L.) Eur. J. Wood Prod. 54:109-112.

Ravenshorst, G.J.P. Species independent strength grading of struc tural timber. Technische Universiteit Delft, Delft, 2015.

Schmidt, M., Glos, P., Wegener, G. (2010) Verklebung von Buchenholz für tragende Holzbauteile. Eur. J. Wood Prod. 68:43-57.

Schmidt, M., Thönnißen, A., Knorz, M., Windeisen, E., Wegener, G. (2012) Relevant wood characteristics for gluing beech and ash with regard to discoloration. Eur. J. Wood Prod. 70:319-325.

Stapel, P., van de Kuilen, J.-W.G. (2014) Influence of cross-section and knot assessment on the strength of visually graded Norway spruce. Eur. J. Wood Prod. 72:213-227.

Torno, S., Knorz, M., van de Kuilen, J.W.G. (2013) Supply of beech lamellas for the production of glued laminated timber. In: $4^{\text {th }}$ 
International Scientific Conference on Hardwood Processing (ISCHP), Florence, Italy.

van de Kuilen, J.-W.G., Torno, S. (2014) Material properties of ash for application in glulam. (in German.) TU München, Munich, $82 \mathrm{pp}$.

Vega, A., Dieste, A., Guaita, M., Majada, J., Baño, V. (2012) Modelling of the mechanical properties of Castanea sativa Mill. structural timber by a combination of non-destructive variables and visual grading parameters. Eur. J. Wood Prod. 70:839-844. von Wedel, K. (1966) Bohrspanuntersuchungen über das Gewicht des Bergahorn und des Spitzahornholzes [Investigations on the weight of increment cores from sycamore and norway maple]. Eur. J. Wood Prod. 24:329-338.

Z-9.1-679. (2013) German technical building approval issued by DIBt for "Glulam from beech wood and beech hybrid glulam beams" (in German), approval issued first on 07. Oct. 2009; approval holder: Studiengemeinschaft Holzleimbau e. V., Germany. Issued by Deutsches Institut für Bautechnik (DIBt), Germany. 


\section{Paper d}

Comparison of three systems for automatic grain angle determination on European hardwood for construction use 


\title{
Comparison of three systems for automatic grain angle determination on European hardwood for construction use
}

\author{
Philipp Schlotzhauer ${ }^{1}$ (]) Fritz Wilhelms ${ }^{1} \cdot$ Christian Lux $^{2} \cdot$ Susanne Bollmus ${ }^{1}$ \\ Received: 15 August 2016 \\ (c) Springer-Verlag GmbH Germany, part of Springer Nature 2018
}

\begin{abstract}
This paper aims to sketch the research results on machine grain angle determination on six indigenous hardwoods and spruce as reference. The system widely used for softwood grain angle determination (tracheid effect) is only restrictedly suitable for hardwoods. Therefore, the systems microwave scanning and electrical field strength measurement were tested as well as the above-mentioned tracheid effect with optimized settings. The measured grain angles were compared to visually determined splitting angles (reference angles). All three machine systems give reliable grain angle values for spruce. For oak, the tracheid effect is not applicable. The reference angle splitting contains weaknesses. Nonetheless, high coefficients of determination $\left(\mathrm{R}^{2}\right)$ indicate a functioning automatic measurement system. Thus, it can be concluded that for the majority of the tested species automatic grain angle determination is possible. Ash does not show satisfactory results.
\end{abstract}

\section{Introduction}

In the year 2011, the German annual felling was made up of about $75 \%$ coniferous round wood (Seintsch and Weimar 2012). This contradicts the availability of the resource. The results of the latest German National Forest Inventory from the year 2015 show that German forests are at present stocked with approximately $54 \%$ coniferous species and $43 \%$ hardwood species. Hardwood forest area increased by around 7.3\% from 2002 to 2012. This trend is expected to continue in the next decades, since Europe-wide new approaches to silviculture call for a maximum increase of biodiversity in forests through the creation of mixed forest stands (Federal Ministry of Food and Agriculture 2014). Therefore, in the future it will be necessary to use hardwood more extensively to meet upcoming demands. One possible application for hardwoods is currently seen in construction, since strength and stiffness (MOE) values exceed those of softwoods in many cases. One main criterion influencing the strength and

Philipp Schlotzhauer pschlot1@gwdg.de

1 Wood Biology and Wood Products, Burckhardt Institute, Georg-August-University of Göttingen, Büsgenweg 4, 37077 Göttingen, Germany

2 Holzforschung Austria, Franz Grill-Strasse 7, 1030 Vienna, Austria stiffness (MOE) values of sawn timber is the grain angle. As Fig. 1 shows, when increasing the angle between wood grain and loading direction, the strength decreases considerably (Kollmann and Côté Jr 1968). The same holds for stiffness.

Grain angle deviations from $0^{\circ}$ appear globally due to spiral grain and milling of bowed or tapered stems. Locally they mostly appear around knots, or in areas, in which a tree experienced top rupture. Global grain angle deviations are normally not as severe as local deviations (Denzler et al. 2013; Denzler and Weidenhiller 2015). A further annotation given by Augustin (2004) on this matter is the fact that by milling round stems into prismatic objects the naturally connected grains (fibers) are severed, resulting in lower strength and stiffness of the sawn timber compared to the round log.

According to the German standard DIN 4074-5 (2008) grain angles can be determined by analyzing shrinkage cracks or by using a scriber (sharp stylus). Local grain deviations resulting from knots are not to be determined. Another visual approach analyzes the surface pattern of the wood to predict grain angles. This can be done automatically via digital image processing. Schickhofer and Augustin (2001) state that this system is open to serious doubt. 


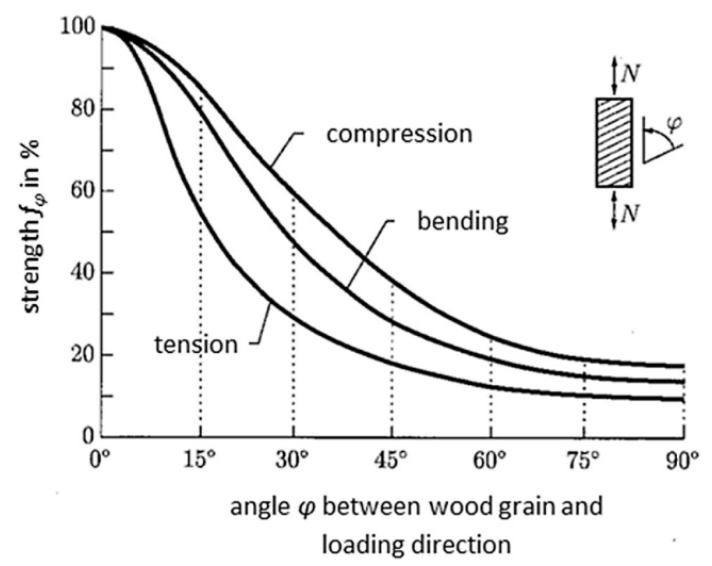

Fig. 1 Influence of the grain angle $(\varphi)$ on tensile, bending and compression strength (adapted from Kollmann and Côté Jr 1968)

\subsection{Tracheid effect}

An effect widely used by grading machines for softwoods is the so-called "tracheid effect". For this method, the wood surface is irradiated with laser light. Part of the light is being reflected, part of it penetrates into the partially luminescent surface of the wood (first few cell layers). The penetrated laser light is being reflected inside the first few cell layers following the optical anisotropy of the wood ("light conductor effect"), i.e. the longitudinal direction of the fibers respectively tracheids. The resulting scattering pattern on the wood surface is a quasi-ellipse, which is then captured by a charge-coupled device (CCD) camera and finally analyzed via digital image processing (Mathews and Beech 1976; Nyström 2003; Simonaho et al. 2004; Sarén et al. 2006).

Satisfactory research results are published for Douglas fir (Pseudotsuga menziesii), lodgepole pine (Pinus contorta), Norway spruce (Picea abies), Scots pine (Pinus sylvestris L.) and sugi (Cryptomeria japonica D.Don) (Simonaho et al. 2004; Hu et al. 2004a; Olsson and Oscarsson 2014; Daval et al. 2015; Schajer and Sutton 2016). Hu et al. (2004b) prove that the system also works for Japanese beech (Fagus crenata Blume), and Simonaho et al. (2004) report good results for silver birch (Betula pubescens Ehrh.). Daval et al. (2015) show the systems functionality for poplar (Populus), while for oak (Quercus petraea) it is evaluated as inefficient, because no ellipse appears. They explain the results with the higher density and the shorter length of the hardwood fibers, which do not diffuse the laser light sufficiently.
Machining of the surface (surface roughness) also has an influence on the scatting pattern of the laser (Shen et al. 2000; Daval et al. 2015). Schajer and Sutton (2016) also prove the systems functionality for 3D grain angle determination (surface plane angle and diving angle) on lodgepole pine (Pinus contorta).

\subsection{Microwave measurement}

For grain angle determination, the microwave and electrical field strength measurement techniques—as radiographic methods-analyze the dielectric properties of wood, which are strongly anisotropic. The relative permittivity of wood for electrical fields is the highest in the longitudinal direction (Norimoto and Yamada 1972; Torgovnikov 1993; Bucur 2003). In the radial and tangential direction it is considerably lower (Norimoto and Yamada 1972). From a dielectric point of view, hardwood species are more anisotropic in the transverse plane $(\mathrm{R} / \mathrm{T})$ than softwood species (Makovíny 1988). Comparing the axial plane (R/L and T/L; direction of fibers respectively tracheids) with the transverse plane (R/T), according to Makovíny (1988) and Kröner and Pungs (1952), softwoods are more anisotropic than hardwoods. This leads to the assumption that the systems, which analyze the dielectric properties for grain angle determination, should work better on softwoods than on hardwoods. Furthermore, the higher heterogeneity of hardwoods concerning the macroscopic structure (more different cell types) can influence the dielectric properties of the wood in a way that makes results hard to interpret.

In contrast to the tracheid effect, which determines grain angles only on the wood surface, these measurements give information about the grain angle for the entire depth of the wood specimen (in this study $30 \mathrm{~mm}$ ).

Using microwave measurement for grain angle determination has been subject to research for some decades now. Several publications give an overview of the research results and the different measurement systems (Torgovnikov 1993; Bucur 2003; Schajer and Orhan 2005; Bogosanovic et al. 2010; Denzler et al. 2013). The results prove that it is possible to determine grain angles via microwave measurement both for hardwood and softwood species. It has also been demonstrated that the system is able to provide data on the three-dimensional grain angle- a diving angle in addition to the surface plane angle (Denzler and Weidenhiller 2015).

Microwaves are electromagnetic waves with frequencies between 1 and $300 \mathrm{GHz}$. The wave characteristics are changed while passing through the wood (Torgovnikov 1993). These changes are mainly influenced by the moisture content of the wood, the density and the grain angle. Consequently, the changes of the wave characteristics can be utilized to determine the above-mentioned wood characteristics. The moisture content has a substantial effect on 
the wave attenuation (reduction of amplitude) and the phase shift (wave length reduction). The phase shift is also affected by the density. By passing through the wood, the formerly linearly polarized wave is becoming elliptically polarized (depolarization). This depolarization is primarily influenced by the grain angle (Torgovnikov 1993; Bucur 2003; Denzler and Weidenhiller 2015). Through sophisticated data analysis, microwave scanning allows the detection of moisture content, density and a three-dimensional grain angle (Schajer and Orhan 2006; Denzler et al. 2014).

Two basic microwave techniques have been proven to work for dielectric measurements on wood. The more recently developed focused beam measurement technique places a wooden specimen between two horn antennas (receiving and transmitting). Between the antennas and the wooden specimen lenses are also located (Bogosanovic et al. 2010). Since resolution is not high enough, local grain angles cannot be detected with this system (Denzler and Weidenhiller 2015). The so-called modulated scattering technique is able to give more local information. Furthermore, it is a simple and affordable solution (Bogosanovic et al. 2010; Denzler and Weidenhiller 2015). In literature, a pronounced disturbing effect of specimen edges is being described (Baradit et al. 2006; Bogosanovic et al. 2010; Denzler et al. 2013). This so-called edge diffraction can either be removed by re-computing the angles (systematic correction) or by extending the specimen on the edges with a material with the same density and material thickness (Denzler et al. 2013). The latter, though, is not practical for an industrial application.

\subsection{Electrical field strength measurement}

The grain angle determination by means of electrical field strength measurement (electrical capacitance) is a further radiographic method. In contrast to the microwave technology, here the test specimen is not irradiated by an electromagnetic wave (Augustin 2004). Instead, a sinusoidal electrical field is applied. Due to the dielectric properties of wood the electrical field experiences a phase shift, when passing through the wood specimen. This phase shift correlates with the grain deviation (slope of grain), and thus the grain angle can be determined (Becker 1993). This system is able to determine the grain angle of planed wood fast, automatic and in a non-destructive way without the need of a skilled and experienced user (McDonald and Bendtsen 1986).

Norton et al. (1974) describes two apparatus set-ups, which allow the measurement of the dielectric constant through electrical field strength measurement.

The first measuring apparatus consists of a pair of spaced flat capacitor plates, which are isolated and located opposite from each other. Together, the flat plates form the surface of a circular disk, which is mounted on a drum. A motor lets the drum rotate at a constant speed. The rotational speed of the drum should be different from overlapping interference frequencies (e.g. power frequencies of $50 \mathrm{~Hz}$ in Europe) and its multiples. Frequencies of 20 or $40 \mathrm{~Hz}$ have been proven to be suitable. The rotation of the capacitor plates generates a sinusoidal electrical field (alternating field). The changes the electrical field experiences through the interaction with the wood specimen (dielectric) are measured in form of a voltage. This voltage is compared to a reference alternating current (AC) voltage, whose frequency is directly related to the rotation speed of the disc, and whose phase corresponds to a grain angle of $0^{\circ}$. Thus, grain angles can be determined. The wood specimen should be placed over the capacitor plates in the least possible distance (max. $3.2 \mathrm{~mm}$ ). Due to the rotation of the capacitor plates, this can lead to material wear between the plates and the wood surface. By placing two measurement apparatuses orthogonally to each other, a three-dimensional grain angle is obtained.

The second apparatus described in literature is not subjected to the above described material wear, since the electrical field is not generated by rotating capacitor plates. The scanning head is stationary and the electrical field vector is caused to rotate electronically. The above mentioned US-patent (Norton et al. 1974) describes a possible system set-up in detail. Comparable to the first apparatus, the grain angle is also determined measuring an output voltage, which is proportional to the phase displacement of the capacitance maximum referred to the longitudinal axis of the wood piece.

Similar to the edge diffraction effect described for microwave measurement techniques (Denzler et al. 2013), this system gives distorted results, when the center point of the detector overlaps the edge of the wood specimen. This edge diffraction can easily be recognized and systematically corrected (McDonald et al. 1988; Schlotzhauer et al. 2014).

The company Metriguard Inc. (Pullman, WA) has developed the only device using the field strength technology for grain angle determination. McDonald and Bendtsen (1986) use a system with a rotating head (Metriguard 5100 Slopeof-Grain Indicator) on the surface of Douglas-fir slats and compare the results with visually determined grain angles. They conclude that the system appears to measure the localized slope of grain (grain angle) accurately. The same device was used to detect defects on red oak boards as a function of grain angles. The results suggest that the system also generates reasonable results for hardwoods (Steele et al. 1991). A study applying a device with a stationary scanning head (Model 511 Grain Angle Meter) to small specimens gives promising results for six European hardwood species (Schlotzhauer et al. 2014). Here the obtained grain angles are compared to splitting angles. According to this study, the splitting angle as reference angle contains sources of error and therefore results have to be evaluated critically. 


\subsection{Other machine systems}

Daval et al. (2015) present a system similar to the tracheid effect, but instead of analyzing the light scattering of the laser on the wood surface, they visualize the resulting heat conduction with an infrared camera. According to the authors, the presented system is able to detect and estimate the slope of grain (grain angle) for any wood species, including hardwood.

Furthermore, it is also possible to facilitate ultrasonic waves for grain angle determination on wood specimens by mapping the variation of the elastic properties in the three different anisotropic planes (Chazelas et al. 1988). For this purpose the ultrasonic velocity is measured for each spot of a selected grid on the wood specimen and afterwards the corresponding modulus of elasticity is calculated (Chazelas et al. 1988; Bucur 2003).

\subsection{Aim of the study}

Automatic grain angle determination on construction timber by means of the tracheid effect is a widely used tool to inspect softwood construction timber in the industry. Together with parameters like dynamic Modulus of Elasticity $\left(\mathrm{MOE}_{\mathrm{dyn}}\right)$, density and others, strength grading is carried out (Olsson et al. 2013). So far, for hardwoods such grading systems are not in use. This is on the one hand due to the comparably low use of hardwood in construction and consequently low research efforts in this field. On the other hand, literature reports a limited functionality of the tracheid effect on hardwoods. Therefore, it is the goal of this research project to evaluate the laser tracheid effect used in the industry for softwood concerning its suitability for grain angle determination on European hardwood timber. As alternative systems, electrical field strength measurement and microwave scanning are tested. The machine measurements are compared to visually determined grain angles on physically split specimens (reference angles).

\section{Materials and methods}

The study was carried out with the six European hardwood species ash (Fraxinus excelsior L.), basswood (Tilia spp. L.), beech (Fagus sylvatica L.), birch (Betula pendula R.), maple (Acer spp. L.) and oak (Quercus spp. L.). Spruce (Picea abies Karst.) was evaluated as reference species, since for this species the "tracheid effect" is widely being used in the industry-as only commercially applied machine grain angle determination system.

For each of the above mentioned species, three planed boards with a large quantity of wood characteristics (e.g. knots of different sizes, grain angle deviations, etc.) were selected for the investigation-resulting in 21 boards. Each board had a length of $1500 \mathrm{~mm}$ and a cross-section of $100 \times 30 \mathrm{~mm}^{2}$. Before measuring the boards, they were conditioned at $20{ }^{\circ} \mathrm{C}$ and $65 \%$ relative humidity.

Measurements were taken for a $25 \times 12.5 \mathrm{~mm}^{2}$ (axial $\times$ radial/tangential) grid over the two wider surfaces $(100 \mathrm{~mm})$ of each board with a measuring accuracy of $0.1^{\circ}$. Afterwards, the specimens were split with a splitting device, which was developed for this study. The grain angles were determined visually. Since preliminary investigations revealed that visual grain angle determination is rather difficult on small size split specimens, the grid was chosen to be $25 \times 12.5 \mathrm{~mm}^{2}$ (axial $\times$ radial/tangential).

\subsection{Stratification}

Former studies have shown that the performance of the system depends greatly on the wood characteristics of the boards (knots, spiral grain, bark ingrowth, etc.). Therefore, it was decided to include stratification (pre-grouping after wood characteristics) to the experimental set-up. The properties of four different strata (groups) were defined as listed in Table 1. The two grouping characteristics were knots and extreme local grain angle changes. It was intended to minimize the characteristics variation within one group to raise the descriptive values of the analysis.

Per species, two board pieces of each $150 \mathrm{~mm}$ length (axially) were selected for each stratum. Thus, for each species

Table 1 Description of strata

\begin{tabular}{llll}
\hline Stratum & Description & $\begin{array}{l}\text { Board pieces } \\
\text { per species }\end{array}$ & $\begin{array}{l}\text { Visual splitting angle } \\
\text { measurements per spe- } \\
\text { cies }\end{array}$ \\
\hline 1 & Straight grained and without knots & 2 & 192 \\
2 & Grain deviation and without knots & 2 & 192 \\
3 & Low grain deviation and small knots $(<15 \mathrm{~mm})$ & 2 & 192 \\
4 & High grain deviation and large knots $(>15 \mathrm{~mm})$ & 2 & 192 \\
& Total & 8 & 768 \\
\hline
\end{tabular}




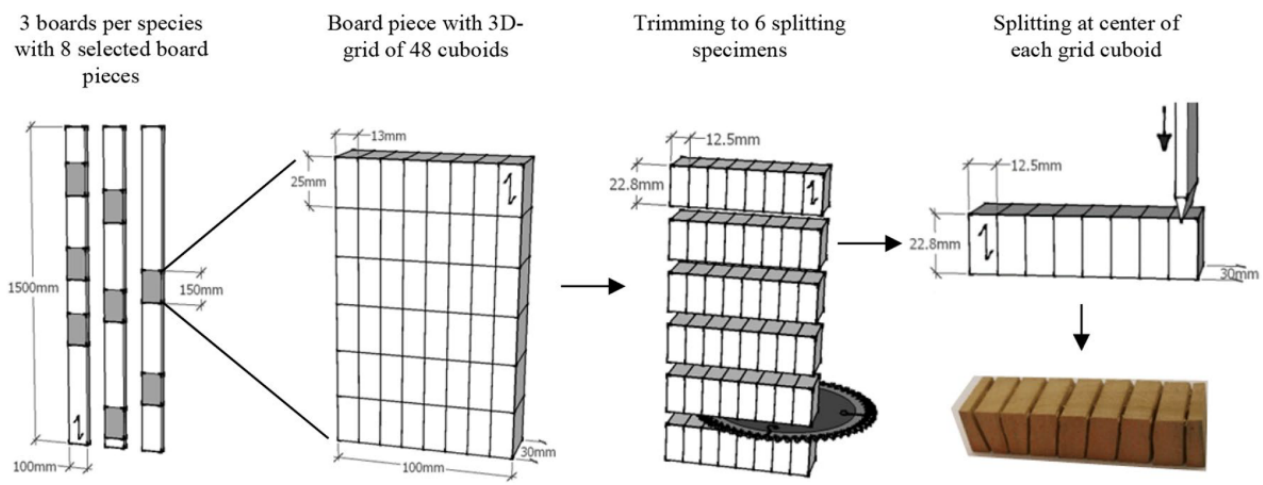

Fig. 2 Chronology of specimen production from 3 boards with 8 board pieces (stratification) to splitting

eight of these board pieces were selected (see Fig. 2) resulting in a total of 56 board pieces for the seven species. The visual splitting angle determination was only carried out for these areas. Each board piece is made up of two (top and bottom) $100 \mathrm{~mm}$ wide (radial/tangential) and $150 \mathrm{~mm}$ long (axial) surface areas, for which splitting grain angles were determined. Per $150 \times 100 \mathrm{~mm}^{2}$ surface, 48 splitting angle measurements ( $8 \mathrm{radial} /$ tangential $\times 6$ axially) were carried out, resulting in 96 measurements per board piece (see Fig. 2). This results in a total number of 5376 visual splitting angle measurements, which are compared to the same number of grain angles attained through the three machine systems.

\subsection{Tracheid effect}

For grain angle determination with this system the apparatus Argus Spectra (ATB Blank GmbH) was used with an automatic feed. A $100 \mathrm{~mW}$ laser with a wavelength of $660 \mathrm{~nm}$ (red) was installed. The resulting scattering patterns on the surface were obtained via a matrix camera and its shape analyzed automatically to obtain a grain angle value. The analyzation approach is similar to the one presented by $\mathrm{Hu}$ et al. (2004a).

As Table 2 shows, the grain angle value obtained for each $25 \times 12.5 \mathrm{~mm}^{2}$ grid center point is the arithmetic mean of 36 single point (ellipse) measurements ( 9 axial and 4 radial/ tangential) on the specimen surface.

\subsection{Microwave measurement}

The measurements were carried out on a prototype developed by the institute EMCE of the Vienna University of Technology and the Austrian Forest Products Research Society (Holzforschung Austria). The prototype is thoroughly described by Denzler and Weidenhiller (2015). The system operates at a frequency of $12 \mathrm{GHz}$, resulting in a resolution of $12.5 \times 12.5 \mathrm{~mm}^{2}$. The boards were moved through the machine manually.

With this apparatus, a high number of parameters can be recorded based on the microwave transmission. These parameters are processed to obtain data on moisture content, density, horizontal grain angle $(\vartheta)$ as well as the so-called diving grain angle $(\omega)$ (Denzler et al. 2014; Denzler and Weidenhiller 2015). For this investigation, only the horizontal grain angle $(\vartheta)$ of each $12.5 \times 12.5 \times 30 \mathrm{~mm}^{3}$ cuboid (volume) was determined. As Table 2 shows, the grain angle value obtained for each $25 \times 12.5 \mathrm{~mm}^{2}$ grid center point is the arithmetic mean of two horizontal grain angle $(\vartheta)$ measurements. Due to the different operating mode of the microwave measurement (measurement through the entire board) in comparison to the other systems, microwave measurements were carried out only on one surface. The obtained value for each $25 \times 12.5 \times 30 \mathrm{~mm}^{3}$ cuboid was used twice in the later comparison (to the splitting angle) - once for the measured side and the negative value of the obtained grain angle value for the opposite side.

\subsection{Electrical field strength measurement}

For these measurements, the only hand-held device commercially available was used-the Model 511 Grain Angle Meter (Metriguard Inc.). The device generates a sinusoidal electrical field with a frequency of $500 \mathrm{kHz}$. The detector lies in the middle of the hand-held device. By laying it on the wood surface a mean grain angle is being measured with a hemispheric volume. This hemisphere has a diameter of $25 \mathrm{~mm}$, resulting in a measurement depth of $12.5 \mathrm{~mm}$. Like in microwave measurement, the grain angle value obtained for each $25 \times 12.5 \mathrm{~mm}^{2}$ grid center point is the arithmetic mean of two electrical field strength measurements (see Table 2). In contrast to the microwave measurement, for 
Table 2 Grain angle determination scheme for one surface (of two) of $25 \times 12.5 \times 30 \mathrm{~mm}^{3}$ cuboid for the four different measurement techniques

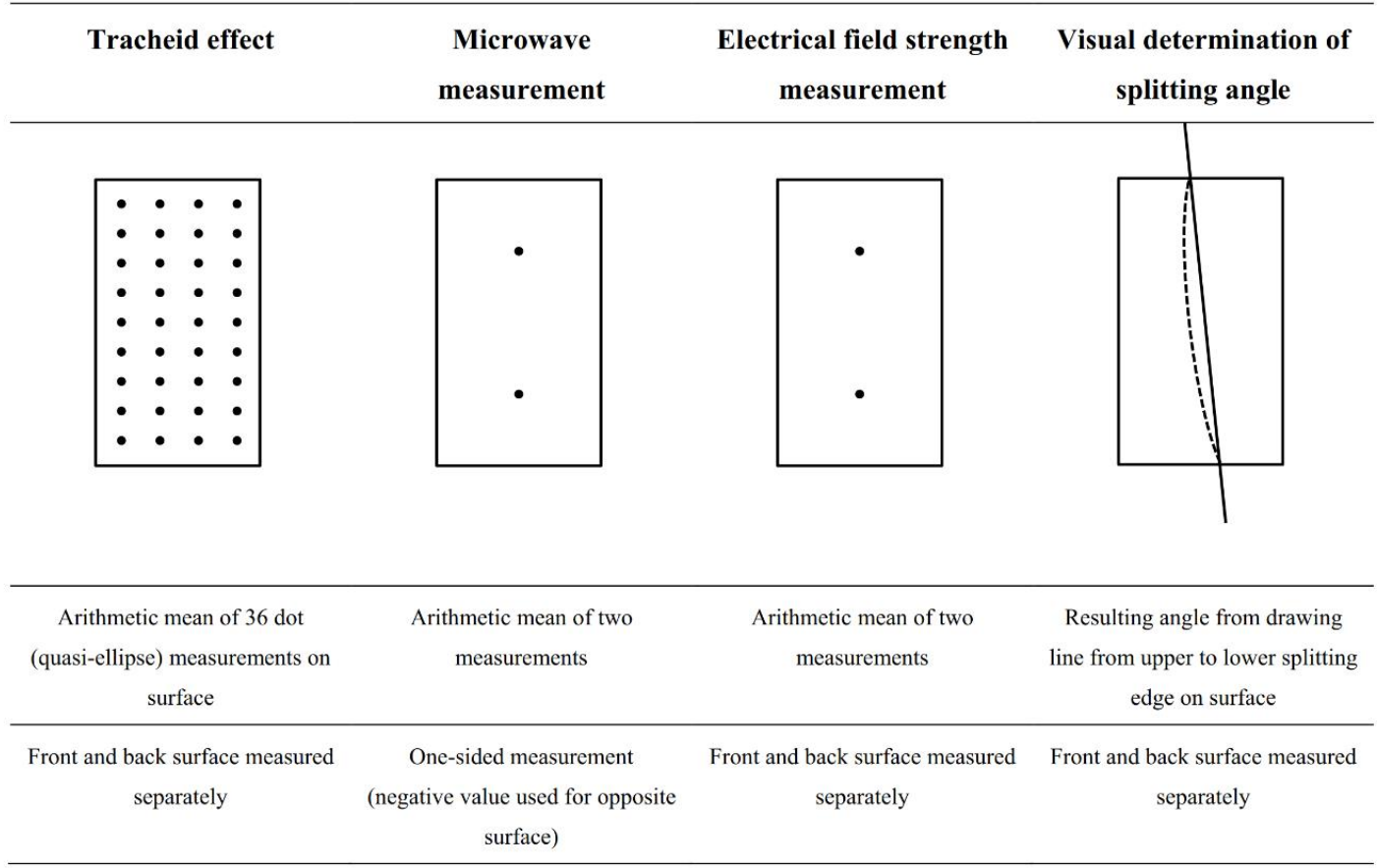

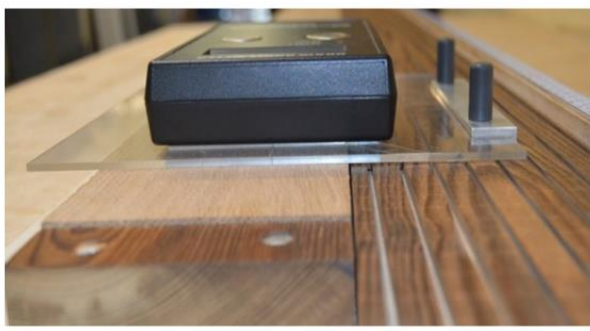

Fig. 3 Semi-automatic measuring device for exact positioning of the grain angle meter

this system the measurements were carried out separately for each surface, since the scanning depth of the system is only $12.5 \mathrm{~mm}$. For semi-automation, a measuring device was constructed allowing the exact positioning of the Grain Angle Meter (Fig. 3).

\subsection{Visual splitting angle determination}

It was intended to compare each of the three machine grain angle values with a reference angle derived from splitting the specimens and determining the angles visually. For this purpose, each board was trimmed to six splitting specimens of $25 \mathrm{~mm}$ length (longitudinally). Since the

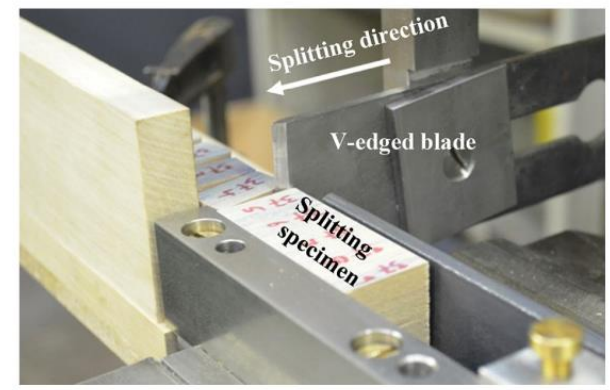

Fig. 4 Splitting of fixed splitting specimen with automatic splitting device

sawblade had a blade thickness of $2.2 \mathrm{~mm}$, the resulting splitting specimens had a final length of $22.8 \mathrm{~mm}$ (see Fig. 2). Each of these splitting specimens (width: $100 \mathrm{~mm}$ ) was afterwards axially split eight times in the center of each grid cuboid (Fig. 2). For splitting, an automated splitting device was developed applying the same force to the splitting specimen at each splitting event (Fig. 4). In this device, the splitting specimen is clamped and split at the desired location with the V-edged splitting blade $(50 \mathrm{~mm}$ wide). The $5 \mathrm{~mm}$ thick blade is fixed to the automated splitting device preventing it from rotating. 


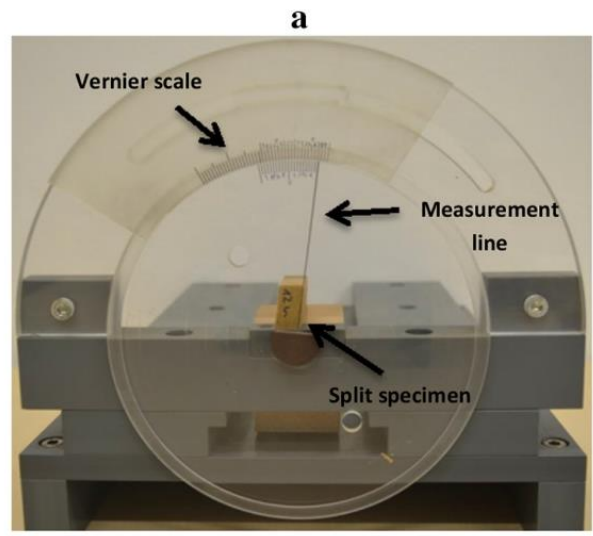

b

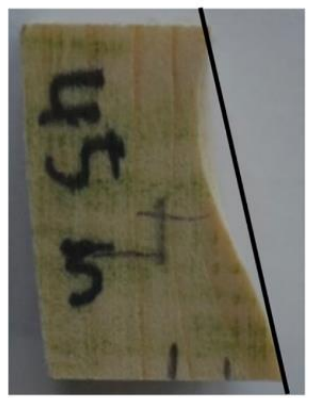

Fig. 5 a Visual grain angle determination device used for this investigation and $\mathbf{b}$ example of a measured split specimen with the projected measurement line

On each resulting splitting specimen the grain angle was determined visually using a device developed at the University of Göttingen (Oliver-Villanueva 1993). For this purpose, the measurement line on the device is aligned with the upper and lower splitting edge on the surface of the split specimen. The specific degree value can then be read manually from a Vernier scale (Fig. 5; Table 2).

\section{Results}

In the following description, the angle values obtained through the three automated devices are compared to the visually determined splitting angles. A grain angle of $0^{\circ}$ equals a straight grain, compared to the longitudinal axis of the board. Figure $5 \mathrm{~b}$ shows a split specimen exhibiting a negative angle value. Here the grain angle is moving from the lower right to the upper left corner of a board surface. A positive angle value describes a grain sloping in the opposite direction.
1-4

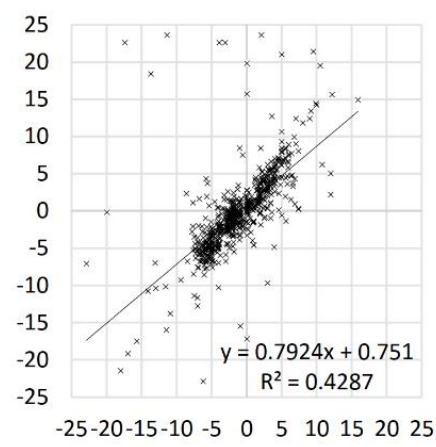

1-2

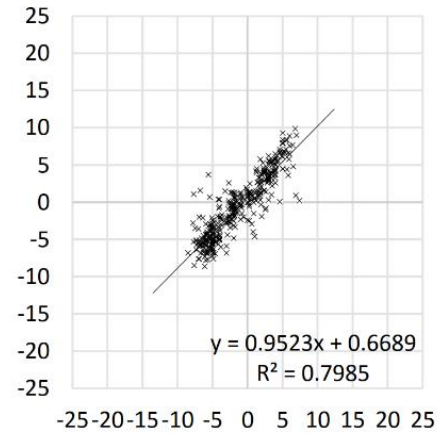

3-4

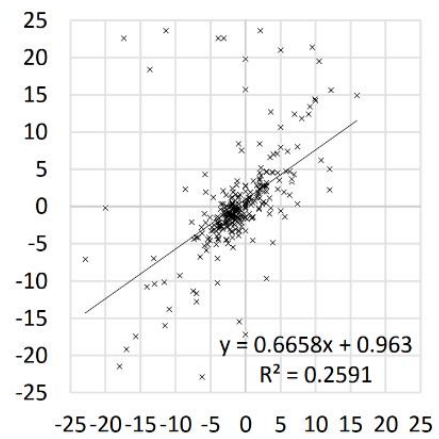

Fig. 6 Scatterplots for oak comparing the angle values obtained with the field strength measurement (y-axis) and the splitting (x-axis) for the entire data set (strata 1-4), for knotless areas (strata group "1-2") and knot containing areas (strata group " $3-4$ ")

As example, Fig. 6 shows scatterplots for the comparison of the splitting and the field strength measurement for the hardwood species oak. The first scatterplot comprises all collected data from stratum 1 to 4 (see also Table 1). The resulting coefficient of determination $\left(\mathrm{R}^{2}\right)$ is with 0.43 small. While a high number of pair of values is situated close to the 
European Journal of Wood and Wood Products

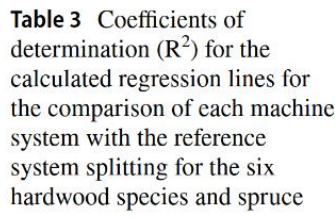

\begin{tabular}{|c|c|c|c|c|c|c|c|c|c|}
\hline \multirow{2}{*}{$\begin{array}{l}\text { System } \\
\text { Strata }\end{array}$} & \multicolumn{3}{|c|}{ Tracheid effect } & \multicolumn{3}{|c|}{ Field strength } & \multicolumn{3}{|c|}{ Microwave } \\
\hline & $1-4$ & $1-2$ & $3-4$ & $1-4$ & $1-2$ & $3-4$ & $1-4$ & $1-2$ & $3-4$ \\
\hline Ash & 0.00 & 0.04 & 0.00 & 0.07 & 0.00 & 0.10 & 0.04 & 0.00 & 0.07 \\
\hline Basswood & 0.44 & 0.71 & 0.21 & 0.37 & 0.23 & 0.40 & 0.06 & 0.16 & 0.02 \\
\hline Beech & 0.20 & 0.53 & 0.12 & 0.28 & 0.66 & 0.20 & 0.17 & 0.35 & 0.12 \\
\hline Birch & 0.37 & 0.51 & 0.35 & 0.34 & 0.48 & 0.32 & 0.04 & 0.00 & 0.10 \\
\hline Maple & 0.52 & 0.81 & 0.33 & 0.14 & 0.51 & 0.01 & 0.67 & 0.88 & 0.56 \\
\hline Oak & 0.12 & 0.20 & 0.07 & 0.43 & 0.80 & 0.26 & 0.36 & 0.73 & 0.15 \\
\hline Spruce & 0.52 & 0.62 & 0.50 & 0.24 & 0.67 & 0.17 & 0.40 & 0.62 & 0.35 \\
\hline
\end{tabular}

regression line, some value pairs show drastic differences between both systems. In the two following scatterplots, the data is divided into one group of specimens without knots (strata group "1-2") and one group of specimens with knots (strata group "3-4"). It becomes clear that the extreme differences in values are mainly found in the specimens with knots (strata group " $3-4$ "), what leads to a low $\mathrm{R}^{2}$ value of 0.26 . For the areas without knots, a high $R^{2}$ value of 0.80 is achieved for oak. This effect is observed for all species in the same manner (see Table 3).

Accordingly, to compare the suitability of the three machine systems for grain angle determination on oak wood, Fig. 7 shows the scatterplots for oak for all three machine measurement systems for the group of specimens without knots (strata group "1-2"). As Daval et al. (2015) already stated, for oak wood the use of the tracheid effect has to be evaluated as inefficient (here $\mathrm{R}^{2}=0.20$ ). The electrical field strength measurement as well as the microwave system show high coefficients of determination $\left(\mathrm{R}^{2}\right)$ for the calculated regression line (0.80 and 0.73 ).

Table 3 lists the attained $\mathrm{R}^{2}$ values for all seven tested species. For spruce, the three systems show comparative values in the strata group " $1-2$ " $(0.62-0.67)$. The other species" $\mathrm{R}^{2}$ values differ between the systems. The use of the tracheid effect resulted in high $\mathrm{R}^{2}$ values for basswood $(0.71)$, maple (0.81) and spruce (0.62). For ash and oak, values are with 0.04 and 0.20 very low. The field strength measurement achieved a strong similarity of the value pairs for beech (0.66), oak (0.80) and spruce (0.67). Ash (0.88), oak (0.73) and spruce $(0.62)$ gave high $\mathrm{R}^{2}$ values for the comparison of the microwave system with the splitting angles. For the hardwood species ash, all coefficients of determination were very low $(<0.05)$.

\section{Discussion}

\subsection{Stratification}

Separate analyses of the four different groups of stratification (strata) did not give clear results, since the sample size within each stratum (per wood species) was too small. However, the method stratification helped to identify the shortcomings of the splitting methods in knot areas. The final grouping into the strata groups " $1-2$ " (no knots) and "3-4" (knot containing) was conclusive. For further investigations, it is advisable to only analyze single characteristics separately (e.g. only straight grained specimens or similar knots), when comparing the suitability of different systems.

\subsection{Tracheid effect}

As mentioned before, the tracheid effect is already widely used in the softwood milling industry, because its functional capability of grain angle determination on softwoods has been proven. The attained $R^{2}$ value for the strata group "1-2" seems with 0.62 comparatively low, while species like basswood and maple attain values of 0.72 and 0.81 . Figure 8 shows the laser scattering patterns on the surfaces of the seven selected wood species. For spruce, a clearly quasielliptical pattern is recognized. The quasi-ellipses have a high major-axis/minor-axis ratio. The comparatively low $\mathrm{R}^{2}$ value compared to basswood and maple can either be due to inaccuracies in the reference method splitting (see below) or characteristics that distort the ellipse formation on the wood surface (e.g. resin pockets, bark ingrowth etc.). Furthermore, a statistical phenomenon appears in this case, which makes comparison of $\mathrm{R}^{2}$ difficult. The variance in angle values is significantly lower for spruce than for basswood and maple (see Fig. 9). Thus, angle differences have a more drastic effect on the $\mathrm{R}^{2}$ value of spruce than of basswood and maple. Figure 10 plots the absolute angle differences for the three species. It becomes clear that for the two hardwood species the angle differences are more pronounced. Their $\mathrm{R}^{2}$ values are higher anyways.

The major-axis/minor-axis ratio of the quasi-ellipses formed on the wood surface is lower for hardwoods (see Fig. 8), although in most cases a direction is still identifiable. For oak, the scattering patterns stay almost circular, with a star-like expression on the edges. The ellipse recognition algorithm falsely identifies this star-like expression as quasiellipse and therefore almost always gives a positive value for 


\section{Tracheid effect}

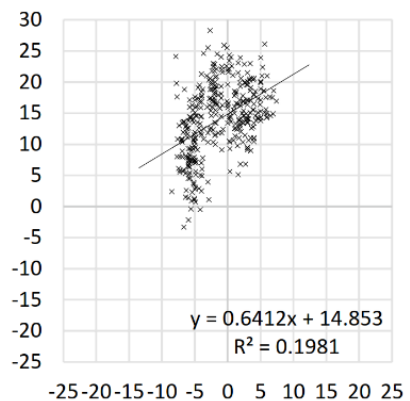

Field strength

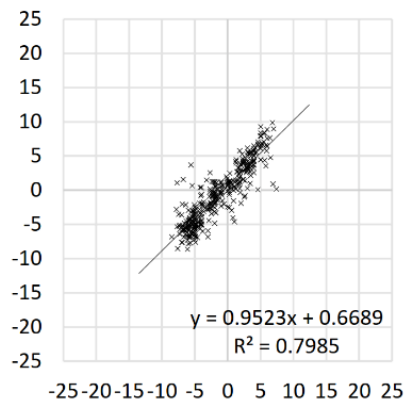

Microwave

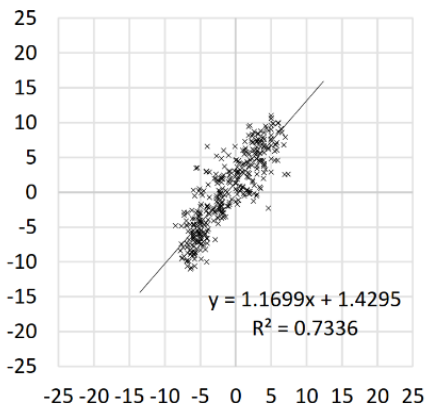

Fig. 7 Scatterplots for oak comparing the angle values of the three different machine systems (y-axis) with the splitting (x-axis) for knotless areas (strata group “1-2”)

the grain angle (see Fig. 7 tracheid effect). The mentioned star-like expression around the recorded quasi-ellipses can be seen for all species. For the two ring-porous species oak and ash, they are very pronounced. Unlike in the case of oak, for ash algorithm adjustments will lead to a considerable raise in $\mathrm{R}^{2}$ values, because the laser dot forms a slight quasi-ellipse. For beech and birch, such algorithm adjustments will lead to satisfactory results, which is in line with the findings of $\mathrm{Hu}$ et al. (2004b) and Simonaho et al. (2004).

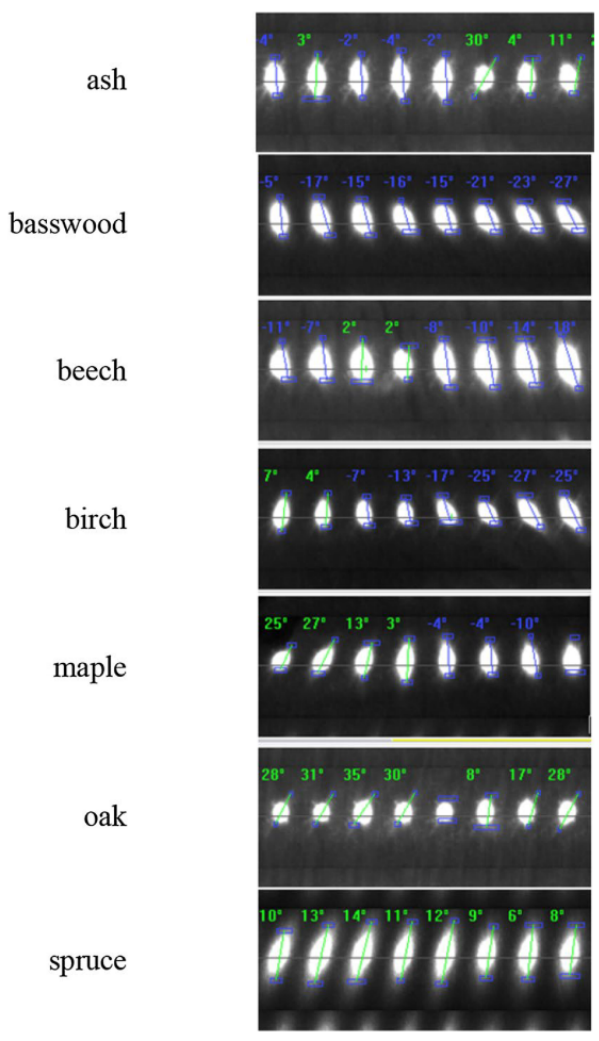

Fig. 8 Laser-dot patterns for the seven investigated species measured with the tracheid effect system. The superimposed lines and the numbers indicate the calculated grain angle

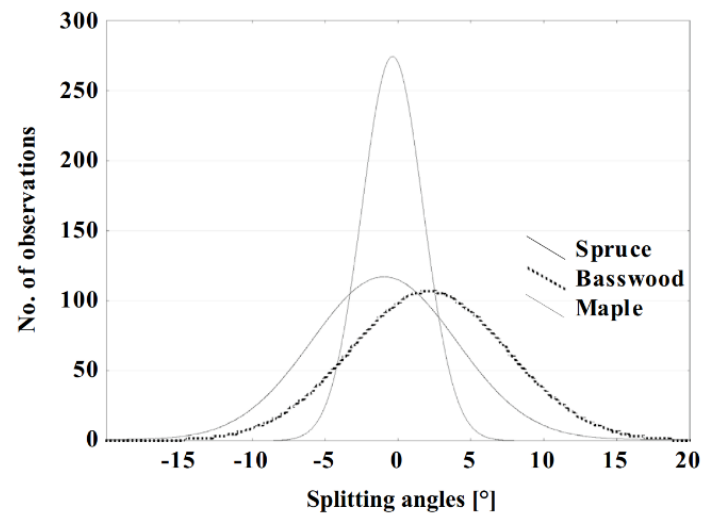

Fig. 9 Frequency curves of the measured splitting angles in the strata group "1-2" for spruce, basswood and maple 


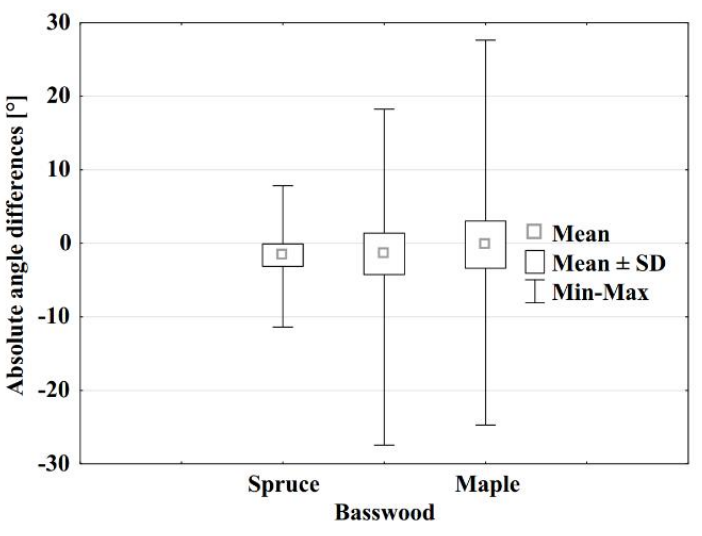

Fig. 10 Boxplots of absolute angle differences in the strata group "1-2" for spruce, basswood and maple

For the hardwood species oak, the microwave system as well as the electrical field strength measurement present a functioning alternative for machine grain angle determination. This contradicts the statement made by Daval et al. (2015) that the introduced system of analyzing heat conduction on the wood surface is the only method of determining grain angles on oak wood.

The differences in quasi-ellipse formation between different species is explained by Daval et al. (2015) with the higher density and the shorter length of the hardwood fibers, which do not diffuse the laser light sufficiently. The appearance of other cell types (i.e. rays, vessels, etc.) must also have an influence on the light reflection. To the best of the authors' knowledge, no literature analyzes the differences in quasi-ellipse formation between different species systematically on the basis of cell type or even cell wall composition.

\subsection{Microwave and electrical field strength measurement}

According to Kröner and Pungs (1952), one reason for the dielectric anisotropy of wood can be the microscopic structure of the main cell type of each species (in most cases fibers and vessels respectively tracheids), for example the length-diameter-ratio, cell wall thickness, cellulose orientation and others. This matter was checked for the studied species, but did not give a conclusive picture. If an effect should be observable, then it should be evident for the electrical field strength measurement and the microwave measurement in a similar magnitude. For the majority of species, though, the two different systems performed extremely different.

Kröner and Pungs (1952) also state that the macroscopic structure of wood is mainly responsible for the dielectric anisotropy (coefficient $\varepsilon_{\mathrm{L}}^{\prime} / \varepsilon_{\mathrm{T}}^{\prime}$ ) of a species. Thus, the grain
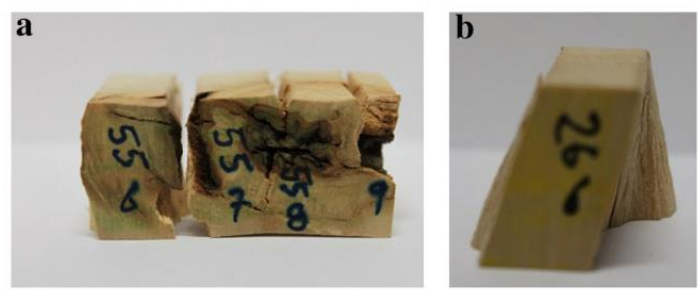

Fig. 11 Splitting results for a a knot containing area and $\mathbf{b}$ a basswood specimen showing a positive splitting angle on the front and a negative splitting angle on the back surface due to spiral grain

angle has a main influence as well as the existence of cell types other than tracheids and fibers. Kröner and Pungs (1952) report a higher dielectric anisotropy for spruce than for beech followed by oak. In line with these findings is the statement of Makovíny (1988), who describes the dielectric anisotropy of wood (coefficient $\varepsilon_{\mathrm{L}}^{\prime} / \varepsilon_{\mathrm{T}}^{\prime}$ ) as a function of vascular ray percentage. He proves that the more vascular rays a specimen/species possesses, the lower the dielectric anisotropy gets. In this study, spruce wood does not always give higher correlations for the electrical field strength measurement and the microwave measurement than hardwoods. Within the group of hardwoods, the results show no clear trend either. The annual ring orientation (radial and tangential orientation) respectively the orientation of vascular rays in the specimens was not considered in this study and was therefore random. This leads to a high variation in the dielectric anisotropy (coefficient $\varepsilon_{\mathrm{L}}^{\prime} / \varepsilon_{\mathrm{T}}^{\prime}$ or $\varepsilon_{\mathrm{L}}^{\prime} / \varepsilon_{\mathrm{R}}^{\prime}$ ) even within one species. This explains why the results do not reflect the findings of Kröner and Pungs (1952) or Makovíny (1988). The selected set-up aims to evaluate the industrial application of machine systems for grain angle determination. Thus, further inaccuracies introduced by the selected set-up overlay the described microscopic and macroscopic effects. Although it will not add descriptive value to this study, it is evaluated as very interesting to analyse the influence of the single cell types on the dielectric anisotropy of the different hardwood and softwood species.

\subsection{Visual splitting angle determination}

The reason for the high values of angle differences in the strata 3 and 4 (see Fig. 6; Table 3) are owed to shortcomings in the reference grain angle. The manual splitting in areas with a high amount of wood characteristics (e.g. knots, spiral grain, bark ingrowth, extreme grain angle changes, etc.) is problematic. Especially big knots present a major challenge for the developed automatic splitting device. Splitting specimens can either not at all be split in these areas or the visually determined angle values are not representative (Fig. 11a). For future investigations of this kind, it will be 
helpful to exclude knots from the final analysis and only use the adjacent areas. Then, extreme values of angle differences between the machine system and the reference method splitting can be avoided. Consequently, the informative value of such a comparative study is raised. Nonetheless, knots are important, strength-reducing board characteristics, which can in fact be identified by using grain angle determination systems. For example, knots can be identified by algorithms searching for extreme value changes in neighboring grid points. For the systems using the tracheid effect and microwave scanning, this can also be done by identifying deep diving angles. Knot identification has been described for all above mentioned machine grain angle determination systems (e.g. Stahl et al. 1990; Steele et al. 1991; Bucur 2003; Baradit et al. 2006; Petersson 2010; Olsson and Oscarsson 2014; Daval et al. 2015). In this manner, it is possible to analyze knots and grain angles at the same time without the application of a second system, potentially lowering the overall costs of sorting. Further models have been developed utilizing the attained data for strength prediction of entire boards (Stahl et al. 1990; Brännström et al. 2008; Olsson and Oscarsson 2014; Denzler and Weidenhiller 2015; Viguier et al. 2015).

There are further deficiencies of the method of comparing visually determined splitting angles with grain angles determined by an automated scanning system. First of all, the accuracy of the visually determined angle depends on the axial distance between the grid points. If the chosen grid is too small, reading the values from the device (Fig. 5a) presents a source of error. The bigger the grid gets, the attained angle becomes more and more an imprecise average of many local grain angles. For example, in Fig. 5b the projected measurement line indicating the measured grain angle on the split specimen shows a negative grain angle, while in the upper third of the specimen the grain angle is clearly positive. The higher the variation in grain angles is, the more drastic this effect gets. The chosen grid length of $22.8 \mathrm{~mm}$ presented an optimal solution for visual angle determination in this study. As measurement repetitions have shown, the person carrying out the measurement also presents a source of error, which cannot be ruled out completely. The splitting itself with the V-edged blade produces unbiased angle values, as Fig. 9 indicates. The splitting angles of the three species shown as well as the other species are normally distributed around the value $0^{\circ}$.

Future investigations should consider and evaluate the use of a different reference method to splitting. For example, specimens could be moved through the machine measurement apparatus at different angles-starting at $0^{\circ}$. With every measurement repetition, the specimen could be turned $1^{\circ}$ further. The resulting angle changes could then be compared to the turning angles. This way, the shortcomings of the reference method splitting could be ruled out.

\subsection{Scanning depth}

As explained in the Sect. 2, the four different grain angle determination systems have different "scanning depths". While the microwave measurement gives an average angle value for a $30 \mathrm{~mm}$ deep cuboid, the electrical field strength measurement gives an average value to a depth of $12.5 \mathrm{~mm}$ for the top and the bottom surface. The tracheid effect as well as the visual angle determination give values only for the surface. Thus, theoretically the tracheid effect values should be closer to the splitting values than the values obtained with the other systems. This effect can be observed clearly for basswood in Table 3. While the tracheid effect exhibits an $\mathrm{R}^{2}$ value of 0.71 in the strata group " $1-2$ ", the field strength measurement shows a value of 0.23 and the microwave system 0.16 . One basswood board was characterized by extreme spiral grain. Figure $11 \mathrm{~b}$ shows one resulting split specimen. In a depth of only $30 \mathrm{~mm}$ the grain angle changes extremely. While the use of the tracheid effect produces similar angle values to splitting, the other methods, which give average values for the described scanning depth, produce highly different values. Equivalent to the biggest scanning depth, the microwave system shows the least correlation between values. This example shows that, despite the stratification process, there are still differences in the occurrence of wood characteristics in the different species (absolute quality differences). This makes comparison of the $\mathrm{R}^{2}$ values difficult.

In summary, high $\mathrm{R}^{2}$ values $(>0.60)$ reported in this study indicate a high suitability of a system for machine grain angle determination. In contrast, low values do not necessarily mean that the system is not suitable for grain angle determination on this species. A mix of distorting factors (scanning depth, reference method, quality difference in specimens) might lead to a low coefficient of determination.

\section{Conclusion}

The three tested systems tracheid effect, microwave measurement and electrical field strength measurement are applicable to grain angle determination on spruce boards confirming the findings of previous publications. The reference method splitting contains sources of errors-especially in knot areas. Therefore, the resulting data has to be evaluated critically. To evaluate the functionality of a machine measurement system for grain angle determination, mainly the analysis of the strata 1 and 2 (knotless areas) is helpful. A different reference system would raise the informative value of such a study substantially.

Only analyzing knotless areas, no system showed satisfactory correlations for all seven selected species. Ash showed no correlation at all $\left(\mathrm{R}^{2}=0.0\right)$, while on basswood only the 
tracheid effect showed a high $\mathrm{R}^{2}$ value $(0.71)$. For beech wood, the electrical field strength measurement showed the highest correlation (0.66). For birch wood, the correlation was the highest, when using the tracheid effect, although the value is with 0.51 low. It is expected by the authors that with rather simple algorithm adjustments, $\mathrm{R}^{2}$ will rise considerably. The system utilizing the tracheid effect is not applicable for oak $\left(R^{2}=0.2\right)$. For oak, the electrical field strength system and the microwave measurement system present true alternatives $\left(R^{2}=0.80\right.$ and 0.73$)$. For maple, the tracheid effect and the microwave systems showed high coefficients of determination $\left(\mathrm{R}^{2}=0.81\right.$ and 0.88$)$.

Acknowledgements This work was supported by the German Federal Ministry of Food and Agriculture through the Agency for Renewable Resources (FNR). Very special thanks go to the Austrian Forest Products Research Society (Holzforschung Austria) for supplying a microwave scanning machine and the company ATB Blank GmbH for contributing the hardware and software to evaluate the 'tracheid effect' on hardwood. A hand-held device for the electrical field strength measurement was supplied by the company Metriguard Inc. (USA) and a second one by the DOKA Group Austria.

\section{References}

Augustin M (2004) Eine zusammenfassende Darstellung der Festigkeitssortierung von Schnittholz [A summary of the strength grading of sawn wood]. Diploma thesis, Graz University of Technology, Austria

Baradit E, Aedo R, Correa J (2006) Knots detection in wood using microwaves. Wood Sci Technol 40:118-123

Becker G (1993) Verfahren der zerstörungsfreien HolzprüfungEntwicklungstendenzen in Nordamerika and Folgerungen für die Anwendung in Mitteleuropa [Methods of non-destructive wood testing-development tendencies in North America and conclusions for application in Central Europe]. Holz Roh- Werkst 51:83-87

Bogosanovic M, Al Anbuky A, Emms GW (2010) Overview and comparison of microwave noncontact wood measurement techniques. J Wood Sci 56:357-365

Brännström M, Manninen J, Oja J (2008) Predicting the strength of sawn wood by tracheid laser scattering. BioResources $3: 437-451$

Bucur V (2003) Nondestructive characterization and imaging of wood. Springer Series in Wood Science, Berlin

Chazelas J, Vergne A, Bucur V (1988) Analyse de la variation des propriétes physique et méchanique locales du bois autour des noeuds [Analysis of the variation of the local physical and mechanical properties of wood around knots]. In: Actes du Colloque Comportement Mecanique du Bois, Bordeaux, pp 376-386

Daval V, Pot G, Belkacemi M et al (2015) Automatic measurement of wood fiber orientation and knot detection using an optical system based on heating conduction. Opt Express 23:33529-33539

Denzler JK, Weidenhiller A (2015) Microwave scanning as an additional grading principle for sawn timber. Eur J Wood Prod 73:423-431

Denzler JK, Koppensteiner J, Arthaber H (2013) Grain angle detection on local scale using microwave transmission. Int Wood Prod J 4:68-74

Denzler JK, Lux C, Arthaber H (2014) Contactless moisture content and density evaluation of sawn timber using microwave transmission. Int Wood Prod J 5:200-206
DIN 4074-5 (2008) Strength grading of wood-Part 5: Sawn hardwood. German Institute for Standardization, Berlin

Federal Ministry of Food and Agriculture (2014) Der Wald in Deutschland-Ausgewählte Ergebnisse der dritten Bundeswaldinventur [The forest in Germany-Selected results of the Third National Forest Inventory]. Bundesministerium für Ernährung und Landwirtschaft (BMEL)

Hu C, Tanaka C, Ohtani T (2004a) On-line determination of the grain angle using ellipse analysis of the laser light scattering pattern image. J Wood Sci 50:321-326

Hu C, Tanaka C, Ohtani T (2004b) Locating and identifying sound knots and dead knots on sugi by the rule-based color vision system. J Wood Sci 50:115-122

Kollmann F, Côté WA Jr (1968) Principles of wood science and technology, I. solid wood. Springer, Berlin

Kröner K, Pungs L (1952) Zur dielektrischen Anisotropie des Naturholzes im großen Frequenzbereich [About the dielectric anisotropy of natural wood in the high frequency range]. Holzforsch-Int J Biol Chem Phys Technol Wood 6:13-16

Makovíny I (1988) The anisotropy of wood dielectric constants as a function of anatomical structure. Holztechnologie 29:210-213

Mathews PC, Beech BH (1976) Method and apparatus for detecting timber defects. U.S. Patent 3976384 A, U.S. Patent Office, Washington, D.C.

McDonald K, Bendtsen BA (1986) Localized slope-of-grain-its importance and measurement. In: Pellerin RF (ed) Proceedings of the 5th nondestructive testing of wood symposium. Washington State University, Pullman, WA, pp 477-489

McDonald K, Cramer S, Bendtsen B (1988) Research progress in modeling tensile strength of lumber from localized slope of grain. In: Proceedings of the 6th Nondestructive testing of wood symposium. Washington State University, Pullman, WA, pp 113-123

Norimoto M, Yamada T (1972) The dielectric properties of wood VI: on the dielectric properties of the chemical constituents of wood and the dielectric anisotropy of wood. Wood Res 52:31-43

Norton JAP, Mclauchlan TA, Kusec DJ (1974) Wood slope-of-grain indicator. U.S. Patent 3805156, U.S. Patent Office, Washington, D.C.

Nyström J (2003) Automatic measurement of fiber orientation in softwoods by using the tracheid effect. Dev Image Process Scan Wood 41:91-99

Oliver-Villanueva JV (1993) Holzeigenschaften der Esche (Fraxinus excelsior L.) und ihre Variabilität im Hinblick auf Alter und Standraum [Wood properties of ash (Fraxinus excelsior L.) and their variability depending on age and stand]. Dissertation, Georg-August-University of Göttingen, Germany

Olsson A, Oscarsson J (2014) Three dimensional fibre orientation models for wood based on laser scanning utilizing the tracheid effect. In: Proceedings of the 2014 World Conference on Timber Engineering (WCTE), Quebec City, Canada

Olsson A, Oscarsson J, Serrano E et al (2013) Prediction of timber bending strength and in-member cross-sectional stiffness variation on the basis of local wood fibre orientation. Eur J Wood Prod 71:319-333

Petersson H (2010) Strength grading and prediction of shape stability by use of optical and laser-based scanning techniques. In: Proceedings of the 11th World Conference on Timber Engineering (WCTE) 2010, Trento, Italy

Sarén M-P, Serimaa R, Tolonen Y (2006) Determination of fiber orientation in Norway spruce using X-ray diffraction and laser scattering. Holz Roh Werkst 64:183-188

Schajer GS, Orhan FB (2005) Microwave non-destructive testing of wood and similar orthotropic materials. Subsurf Sens Technol Appl 6:293-313 
Schajer GS, Orhan FB (2006) Measurement of wood grain angle, moisture content and density using microwaves. Holz Roh- Werkst 64:483-490

Schajer GS, Sutton DB (2016) Identification of 3D wood grain angle by directional reflection measurement. Wood Mater Sci Eng 11:170-175

Schickhofer G, Augustin M (2001) EU-Project INTELLIWOOD—final report; working package 3: strength correspondence. Graz, Austria

Schlotzhauer P, Emmerich L, Militz H, Bollmus S (2014) Machine grain angle determination on six European hardwoods. In: Németh $\mathrm{R}$, Teischinger A, Schmitt U (eds) Proceedings of the "IAWS Plenary Meeting 2014_Sopron (Hungary)_Vienna (Austria) -Eco-efficient Resource Wood with special focus on hardwoods, University of West Hungary Press, Sopron, Hungary, pp 45-46

Seintsch B, Weimar H (2012) Actual situation and future perspectives for supply and demand of hardwood in Germany. In: Nemeth R, Teischinger A (eds) The 5th conference on hardwood research and utilisation in Europe 2012. University of West Hungary Press, Sopron, pp 301-312
Shen J, Zhou J, Vazquez O (2000) Experimental study of optical scattering and fiber orientation determination of softwood and hardwood with different surface finishes. Appl Spectrosc 54:1793-1804

Simonaho S-P, Palviainen J, Tolonen Y, Silvennoinen R (2004) Determination of wood grain direction from laser light scattering pattern. Opt Lasers Eng 41:95-103

Stahl DC, Cramer SM, McDonald KA (1990) Modeling the effect of out-of-plane fiber orientation in lumber specimens. Wood Fiber Sci 22:173-192

Steele PH, Neal SC, McDonald KA, Cramer SM (1991) The slope-ofgrain indicator for defect detection in unplaned hardwood lumber. For Prod J 41:15-20

Torgovnikov GI (1993) Dielectric properties of wood and wood-based materials. Springer, Berlin

Viguier J, Jehl A, Collet R et al (2015) Improving strength grading of timber by grain angle measurement and mechanical modeling. Wood Mater Sci Eng 10:145-156 


\section{Paper e}

Effect of size and geometry on strength values and MOE of selected hardwood species 


\title{
Effect of size and geometry on strength values and MOE of selected hardwood species
}

\author{
P. SCHLOTZHAUER ${ }^{1}$, P. A. NELIS ${ }^{1}$, S. BOLLMUS ${ }^{1}$, A. GELLERICH ${ }^{1}$, H. MILITZ ${ }^{1}$, \& \\ W. SEIM ${ }^{2}$ \\ ${ }^{1}$ Department of Wood Biology and Wood Products, Georg-August-University of Göttingen, Göttingen, Germany, and \\ ${ }^{2}$ Department of Timber Structures and Building Rehabilitation, University of Kassel, Kassel, Germany
}

\begin{abstract}
The total hardwood timber stock of German forests is fast growing. The lack of knowledge concerning test standards, product standards and sorting criteria makes it difficult to expand the processing and marketing of hardwoods into the field of construction usage. Strength and stiffness data derived from small, defect-free specimens do mostly exist, but in order to be able to insert hardwoods into building applications, data derived from real size specimens is needed. Subsequently, the results of these two different specimen categories need to be correlated and the so-called size effect needs to be quantified and qualified. This paper aims to analyze the size effect of defect-free compression, bending and tensile specimens for the six European hardwood species maple (Acer spp.), birch (Betula pendula), beech (Fagus sylvatica), ash (Fraxinus excelsior), oak (Quercus $s p p$.) and lime (Tilia $s p p$.). They are tested exclusively parallel to grain. Regarding the compression strength for maple, birch and ash, the specimen dimensions did not influence the compression strength value. For beech, oak and lime, it was observed that compression strength increased as the specimen volume was increased. The bending strength of all species decreased as the specimen dimensions increased. Concerning the tensile strength, a clear statement on whether dimensions influence the tensile strength value is not possible. Further research with adjusted specimen sizes, specimen shapes and machine set-ups is needed. Regarding the compression and bending MOE, in most cases, the dimensions did not influence the MOE values. In tensile testing, MOE values differed significantly for the different specimen sizes. Whether these differences were due to slightly different test set-ups in the different sizes or a true size effect could not be answered conclusively.
\end{abstract}

Keywords: Bending strength testing, compression strength testing, hardwood, size effect, tensile strength testing, MOE

\section{Introduction}

Currently, the forests of Germany and Central Europe are undergoing changes in stocking area. While to date, Germany's 10.1 million hectare stocking area is made up of $43 \%$ hardwood trees, in the first age class ( 1 to 20 years old stands), this group already covers $54 \%$ of the stocking area (Oehmichen et al. 2011). Seintsch and Weimar (2012) state that in the future, it will not be possible to maintain the actual level of softwood fellings (with special emphasis on spruce). In 2011, 68.4 million $\mathrm{m}^{3}$ were felled. Only $20 \%$ of these fellings were comprised of hardwoods (Seintsch and Weimar 2012). With a rising supply of hardwood, new sales markets need to be found. One option will be the application in the building sector as substitution for the diminishing spruce stock. For this application, fundamental scientific data need to be gathered in the next years. Next to the determination of general elasto-mechanic properties, research on strength grading (according to DIN EN 14081 2012) of hardwoods needs to be carried out. The so-called size effect is an important aspect of this research.

In literature, many authors state that mechanical properties of specimens are dependent on the specimen dimensions (Schneeweiß 1964, Bohannan 1966, Showalter et al. 1987). This phenomenon is often called size effect. According to Denzler (2007), already in 1906, Tanaka describes the influence of cross-section height on bending strength and presumes a dependence on the species. Until

Correspondence: P. Schlotzhauer, Department of Wood Biology and Wood Products, Georg-August-University of Göttingen, Büsgenweg 4, D-37077 Göttingen, Germany. Tel: +49 551 3933562. Fax: +49551 399646. E-mail: pschlot1@gwdg.de 


\section{P. Schlotzhauer et al.}

today, a lot of research has been done on bending, compression and tensile strengths of wood regarding the size effect (see below). The focus, though, has mostly been set on softwood species. Depending on the wood product (glulam, solid wood, veneer, etc.), the different mechanical tests (bending, compression or tensile test) and the grain direction, various authors are following different approaches in order to explain the size effect. The most famous approach is Weibull's weakest link theory. It is applied to bending, compression and tensile tests (perpendicular or parallel to grain). Weibull (1939) states that increased stressed volume is attended by a decrease in wood strength due to stochastically appearing weak locations in the wood. Thus, there is an increased probability of encountering a strength-reducing flaw, when the volume of the material under stress is increased (Pedersen et al. 2003). Since the turn of the century, several authors have found evidence for the hypothesis that the size effect cannot only be explained by Weibull's theory, but also by the (cylindrical orthotropic) structure of wood - a deterministic explanation instead of only a stochastic one (Hoffmeyer et al. 2000, Pedersen et al. 2003, Astrup et al. 2007).

The analysis of the influencing factors on the size effect of strength and elastic properties is very complex and a number of hypotheses have been developed in the last 100 years. To simplify the matter, it is helpful to look at different species and the different mechanical tests separately. Results of the microscopic and macroscopic (and even massive) scale as well as defect-free specimens and construction timber (different grades) have to be distinguished (Smith et al. 2003, Buchelt and Pfriem 2011, Schneeweiß and Felber 2013).

This study has four main objectives:

- provide strength values derived from defectfree specimens of different sizes,

- provide MOE values derived from defect-free specimens of different sizes,

- examine the so-called size effect for selected hardwoods, and

- evaluate, if the possible specimen length range $(30-60 \mathrm{~mm})$ stated in the DIN 52185 (1976) for little error-free compression specimens, produces different strength and MOE values.

For the six European hardwood species, maple (Acer pseudoplatanus, A. platanoides), birch (Betula pendula), beech (Fagus sylvatica), ash (Fraxinus excelsior), oak (Quercus petraea, Q. robur) and lime (Tilia cordata, T. platyphyllos) compression, bending and tensile tests (all parallel to grain) were carried out. Inside a genus, it cannot be distinguished between single species and their exact share, since all wood was ordered through regular timber trade companies and thus had the customary characteristics. The six hardwood species were selected due to their availability in northern Germany and their promising wood characteristics in relation to construction use.

\section{Material and methods}

\section{Material}

Table I shows the amount of samples tested for each species and each size. It also visualizes the size differences between the specimens.

To be able to compare the results with literature values available on the matter, standard specimens (named Standard) were produced according to the German test standards for little, defect-free specimens. These standards are:

- DIN 52185 (1976) for compression,

- DIN 52186 (1978) for 3-point-bending, and

- DIN 52188 (1979) (adapted) for tension.

As representative for construction timber, the socalled Real size specimens were produced - also defect-free. They were produced in accordance with test standard EN 408 (2003). For Real size compression and tensile testing, the specimens were also produced in accordance with Blaß et al. (2005). The tensile test specimen proposed by Blaß et al. (2005) and tested in this study deviate in length from EN 408 (2003) specimens.

To create an additional link between the standard specimens and the Real size specimens, a third group of specimens was established - the F5 specimens. They show the same length-to-width-toheight ratio as the Real size specimens - with the reduction factor of 5 (therefore named F5). Their lengths (longitudinal direction) are similar to the Standard specimens.

The year ring orientation of the specimens was clearly defined (Table I) and in the case of the Standard specimens according to the test standards. Only the Real size specimens had varying year ring orientations, due to their sizes.

In total, in the course of this study, 833 specimens for compression testing, 428 specimens for bending testing and 392 specimens for tensile testing were tested. The smaller specimen number in bending and tensile testing compared to compression testing is due to the considerably higher material use in Real size testing. Therefore, for Real size bending and tensile testing, it was decided to reduce the sample number $(\mathrm{n})$ per species from approximately 30 to 10 . 
Table I. Overview of the amount of samples (n) tested per species and size.

\begin{tabular}{|c|c|c|c|c|c|c|c|}
\hline Specimen name & Maple & Birch & Beech & Oak & Ash & Lime & Figure \\
\hline \multicolumn{8}{|l|}{ Compression test (long. $\times$ rad. $\times$ tang.) } \\
\hline Standard $3\left(30 \times 20 \times 20 \mathrm{~mm}^{3}\right)$ & 37 & 34 & 34 & 46 & 44 & 49 & 日 \\
\hline Standard6 $\left(60 \times 20 \times 20 \mathrm{~mm}^{3}\right)$ & 30 & 35 & 32 & 34 & 39 & 30 & $\boxminus$ \\
\hline Real size $\left(200 \times 100 \times 30 \mathrm{~mm}^{3}\right)$ & 32 & 29 & 27 & 27 & 30 & 29 & \\
\hline F5 $\left(40 \times 20 \times 6 \mathrm{~mm}^{3}\right)$ & 37 & 33 & 34 & 35 & 44 & 32 & $\square$ \\
\hline \multicolumn{8}{|l|}{ Bending test (3-point) } \\
\hline Standard $\left(380 \times 20 \times 20 \mathrm{~mm}^{3}\right)$ & 32 & 37 & 33 & 29 & 32 & 42 & $\longrightarrow$ \\
\hline Real size $\left(1900 \times 100 \times 30 \mathrm{~mm}^{3}\right)$ & 10 & 10 & 10 & 10 & 10 & 10 & \\
\hline F5 $\left(380 \times 20 \times 6 \mathrm{~mm}^{3}\right)$ & 25 & 28 & 27 & 28 & 28 & 27 & $\Longrightarrow$ \\
\hline \multicolumn{8}{|l|}{ Tensile test } \\
\hline Standard $\left(300 \times 20 \times 5 \mathrm{~mm}^{3}\right)$ & 29 & 32 & 30 & 30 & 34 & 29 & 夏巨正 \\
\hline Real size $\left(800 \times 100 \times 30 \mathrm{~mm}^{3}\right)$ & 10 & 10 & 10 & 10 & 10 & 10 & \\
\hline F5 $\left(160 \times 20 \times 6 \mathrm{~mm}^{3}\right)$ & 25 & 25 & 25 & 25 & 24 & 24 & ب \\
\hline
\end{tabular}

\section{Methods}

After the specimens were produced, they were conditioned at a temperature of $20^{\circ} \mathrm{C}$ and a relative humidity of $65 \%$ until the equilibrium moisture content was reached. Thereafter, their density was determined according to DIN 52182 (1976). The compression, bending and tensile tests were carried out in accordance with the above-mentioned standards and literatures. Deformation was mostly measured with a contact-free system (camera system VideoXtens from Zwick/Roell). Only for the Real size specimens of the compression and tensile test, a clip-on extensometer was used. Directly after testing the specimens, the moisture content was determined according to DIN 52183 (1977).

Table I shows the grouping for the statistical analysis of the results. For each species separately, the three different sizes (for compression testing four sizes) were tested for significant differences. To test the different groups for significant differences with an ANOVA, the data must fulfill the normality assumption and the assumption for homogeneity of variances. The assumption of normality was tested using the Shapiro-Wilk's $W$ test. For testing the assumption of homogeneity of variances, the Levene test was performed. The assumptions were rejected at an error level (p-value) beyond 0.05. If one or two of the assumptions were not met, the nonparametric Kruskal-Wallis ANOVA and Median Test was selected to test for significant differences between the single specimen sizes. Differences in strengths and MOE data between the specimen sizes were regarded significant at an error level beyond 0.05. Thereafter, it was assessed, if a possible explanation for significant differences was either varying moisture content or a varying density between two groups.

\section{Results and discussion}

General information

As representative example, Figure 1 shows the boxplots of the bending strength $\left[\mathrm{N} / \mathrm{mm}^{2}\right]$ of birch (Betula pendula). Additionally, it provides the mean density and mean moisture content within each group. Table II summarizes the subsequent statistical analysis. The F5 specimens show no significant difference compared to Real size and Standard. Real size and Standard, though, are different from each other. In this case, the mean densities and the mean moisture contents did not differ by much. Hence, it can be assumed that they did not have any influence on the strength results.

This analysis was carried out for each species of each test - resulting in 18 single analyses for strength. Additionally, 18 statistical analyses were carried out for MOE.

\section{Compression strength}

Regarding the compression strength values, lime achieved the lowest mean values with $38.48 \mathrm{~N} / \mathrm{mm}^{2}$ (Table III). The highest strength was achieved by the Real size birch specimens (mean $61.15 \mathrm{~N} / \mathrm{mm}^{2}$ ). The strength values inside the groups varied only to a small extent (SD 1.67-7.25 N/ $\mathrm{mm}^{2}$ ). The standard deviations between the different specimen sizes and species also showed a small variation.

Comparing the compressions strength values (Table III) attained through this study (Standard3 and Standard6) with mean values for little 


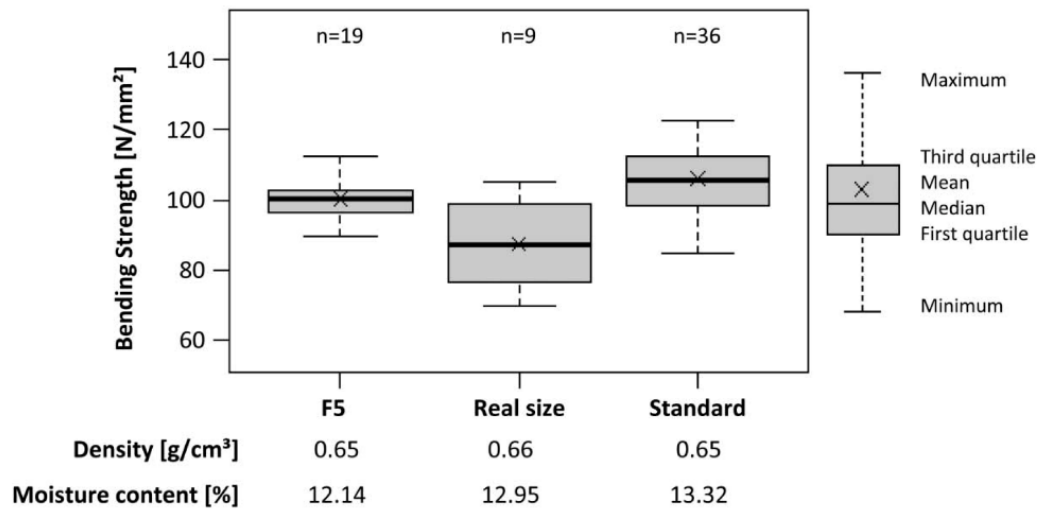

Figure 1. Boxplot of bending strength $\left[\mathrm{N} / \mathrm{mm}^{2}\right]$ of birch dependent on specimen size. Below mean density $\left[\mathrm{g} / \mathrm{cm}^{3}\right]$ and mean moisture content [\%] per specimen size are listed.

Table II. Statistical analysis comparing the strength values of the bending specimen sizes of birch.

\begin{tabular}{lccc}
\hline & F5 & Real size & Standard \\
\hline F5 & $\mathrm{x}$ & $\mathrm{N}$ & $\mathrm{N}$ \\
Real size & & $\mathrm{x}$ & $\mathrm{Y}$ \\
Standard & & & $\mathrm{x}$ \\
\hline
\end{tabular}

Significant differences are marked with Y (light grey) and not significant differences with $\mathrm{N}$ (dark grey).

defect-free specimens provided by DIN 68364 (2003) and Wagenführ (2007):

- maple and birch showed similar mean values,

- beech, oak and ash values were lower than the ones listed by the standard,

- with $39 \mathrm{~N} / \mathrm{mm}^{2}$ the lime mean value was by far lower than the literature value (Wagenführ 2007).

Concerning the size effect, one objective of this study was to evaluate, if the two different lengths (longitudinal direction) of the standard specimens (according to DIN $52185197630 \mathrm{~mm}$ and $60 \mathrm{~mm}$ ) produce different strength results. This was not the case. Comparing all four different sizes, for maple, birch and ash, the specimen dimensions did not influence the values. For beech, oak and lime, it was observed that compression strength increased as specimen volume was increased. This is contradictory to Weibull's (1939) theory, which states that with increasing volume, the strength decreases. Schneeweiß (1964) concluded that the volumestrength dependence is a function of absolute specimen volume. He established three different categories. At volumes below $10 \mathrm{~cm}^{3}$ (Category 1) and above $1000 \mathrm{~cm}^{3}$ (Category 3), Weibull's theory applies. In between (Category 2), the volume is considered an influencing factor of low importance. Only considering the volume of Real size $\left(600 \mathrm{~cm}^{3}\right)$, Standard6 $\left(24 \mathrm{~cm}^{3}\right)$, Standard $3\left(12 \mathrm{~cm}^{3}\right)$ and F5 $\left(4.8 \mathrm{~cm}^{3}\right)$, the results of this study confirm the categorization of Schneeweiß (1964). To fully support Schneeweiß (1964), geometrical similarity is a prerequisite. Real size specimens and Standard specimens

Table III. Compression strengths derived from defect-free specimens of different sizes - Mean \pm SD $\left[\mathrm{N} / \mathrm{mm}^{2}\right]$.

\begin{tabular}{|c|c|c|c|c|c|c|}
\hline Specimen size & Maple & Birch & Beech & Oak & Ash & Lime \\
\hline $\begin{array}{l}\text { Standard3 } \\
\text { (a) }\end{array}$ & $\begin{array}{c}54.52 \pm 2.13 \\
(0)\end{array}$ & $\begin{array}{c}59.42 \pm 5.05 \\
\text { (d) }\end{array}$ & $\begin{array}{c}49.33 \pm 2.27 \\
\text { (c) }\end{array}$ & $\begin{array}{c}41.69 \pm 2.24 \\
(\mathrm{c}, \mathrm{d})\end{array}$ & $\begin{array}{c}46.85 \pm 3.73 \\
(0)\end{array}$ & $\begin{array}{c}38.48 \pm 2.50 \\
(\mathrm{c}, \mathrm{d})\end{array}$ \\
\hline $\begin{array}{l}\text { Standard6 } \\
\text { (b) }\end{array}$ & $\begin{array}{c}53.43 \pm 2.32 \\
\text { (c) }\end{array}$ & $\begin{array}{c}57.81 \pm 2.53 \\
(0)\end{array}$ & $\begin{array}{c}50.01 \pm 2.95 \\
(\mathrm{c}, \mathrm{d})\end{array}$ & $\begin{array}{c}42.07 \pm 1.83 \\
(\mathrm{c}, \mathrm{d})\end{array}$ & $\begin{array}{c}44.19 \pm 3.53 \\
(0)\end{array}$ & $\begin{array}{c}39.55 \pm 3.23 \\
(\mathrm{c}, \mathrm{d})\end{array}$ \\
\hline $\begin{array}{l}\text { Real size } \\
\text { (c) }\end{array}$ & $\begin{array}{c}55.65 \pm 3.04 \\
(\mathrm{~b}, \mathrm{~d})\end{array}$ & $\begin{array}{c}61.15 \pm 5.62 \\
\text { (d) }\end{array}$ & $\begin{array}{c}58.59 \pm 5.25 \\
(a, b, d)\end{array}$ & $\begin{array}{c}45.16 \pm 2.96 \\
(a, b, d)\end{array}$ & $\begin{array}{c}46.78 \pm 5.47 \\
\text { (0) }\end{array}$ & $\begin{array}{c}47.18 \pm 3.60 \\
(\mathrm{a}, \mathrm{b})\end{array}$ \\
\hline $\begin{array}{l}\text { F5 } \\
\text { (d) }\end{array}$ & $\begin{array}{c}53.00 \pm 3.65 \\
\text { (c) }\end{array}$ & $\begin{array}{c}55.60 \pm 3.51 \\
(\mathrm{c}, \mathrm{a})\end{array}$ & $\begin{array}{c}46.64 \pm 4.22 \\
(\mathrm{~b}, \mathrm{c})\end{array}$ & $\begin{array}{c}38.67 \pm 1.67 \\
(\mathrm{a}, \mathrm{b}, \mathrm{c})\end{array}$ & $\begin{array}{c}45.53 \pm 7.25 \\
\text { (0) }\end{array}$ & $\begin{array}{c}43.35 \pm 3.85 \\
(\mathrm{a}, \mathrm{b})\end{array}$ \\
\hline
\end{tabular}

Literature value (mean) 50 (DIN 68364) 60 (DIN 68364) 60 (DIN 68364) 52 (DIN 68364) 50 (DIN 68364) 52 (Wagenführ 2007)

The letter/digit in exclamation marks shows the specimen size (group) this specimen size differs from (statistically significant). 0 means that this specimen size is not statistically significantly different from any other specimen size. 
(Standard3 and Standard6), though, show only little similarity in geometry. To determine the effect a change in one single dimension (e.g. width) has on the compression strength, more different sizes than the four tested in this study need to be compared. The similar results produced by the two different standard specimens, though, indicate that as long as there is no buckling, a length (long. direction) change does not affect the compression strength.

The mode of failure is also affected by the specimen dimensions. In Standard3 and Standard6 specimens, the predominating failure mode was the typical formation of compression wrinkles due to buckling of fibers (Figure 2(b)). Here, the lime specimens showed a completely different behavior. At the bottom and top of these specimens, a bulge was formed (Figure 2(a)). This difference in failure mode could not be observed in Real size and F5 specimens. Here, buckling of the entire specimen with subsequent formation of strong compression wrinkles was the typical reaction of the specimen to compression stress. This strong buckling indicated that for compression testing, the chosen length-to-width-to-height ratio of Real size and F5 specimens is not optimal. Although the compression strength values of the Real size specimens were always higher than those of the Standard ( $3 \& 6$ ) specimens, it has to be stated that due to the buckling, it is not a pure compression test anymore.

As mentioned above, Schneeweiß (1964) analyses the size effect in compression testing in depth. Okohira et al. (1989) confirm those findings. Madsen (1992) and Burger (1998) also prove a size effect in compression testing. The latest publication on the matter is Schneeweiß and Felber (2013), in which literature lists for publications on compression, bending and tensile tests can be found. Here, it becomes obvious that most of the findings result from tests with softwoods. Another detail that needs to be kept in mind when comparing test results with older findings is whether clear-wood specimens (defect-free) were tested or not. In compression testing, this is mostly the case, but bending and tensile tests are often carried out on structural timber, which shows typical wood characteristics like knots and grain deviations.

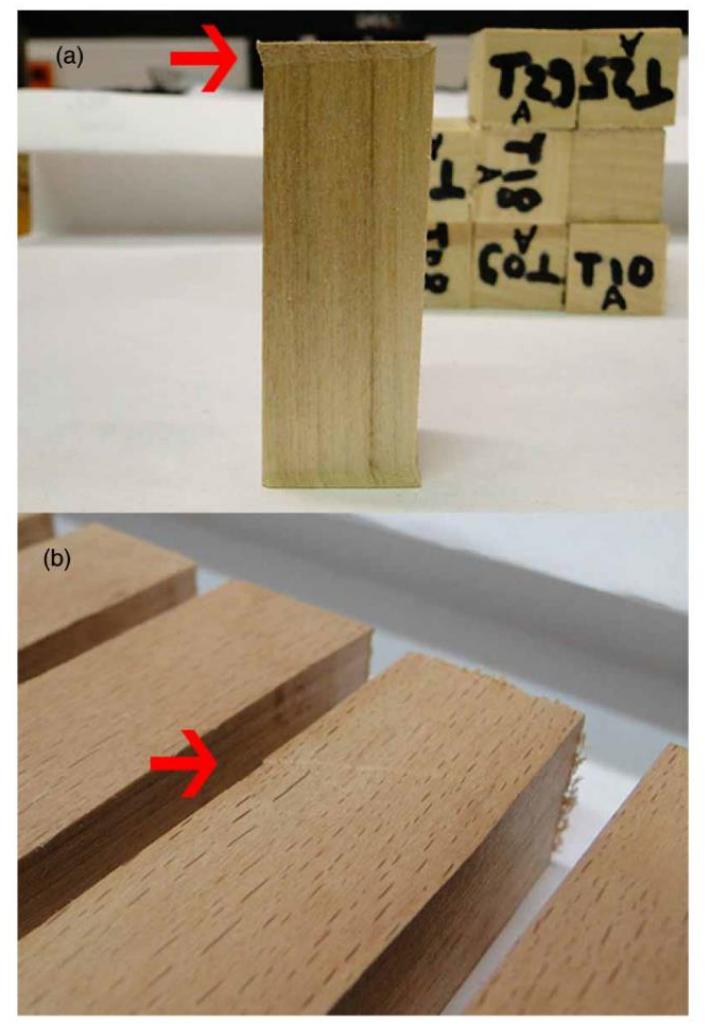

Figure 2. Standard compression specimen failure modes. (a) It shows the compression failure mode of lime. (b) It shows the compression failure mode of beech representative for all other species. 
P. Schlotzhauer et al.

Table IV. Bending strengths derived from defect-free specimens of different sizes - Mean \pm SD $\left[\mathrm{N} / \mathrm{mm}^{2}\right]$.

\begin{tabular}{|c|c|c|c|c|c|c|}
\hline Specimen size & Maple & Birch & Beech & Oak & Ash & Lime \\
\hline $\begin{array}{l}\text { Standard } \\
\text { (a) }\end{array}$ & $\begin{array}{c}108.23 \pm 6.66 \\
\text { (b) }\end{array}$ & $\begin{array}{c}106.09 \pm 9.37 \\
\text { (b) }\end{array}$ & $\begin{array}{c}120.64 \pm 8.64 \\
(b, c)\end{array}$ & $\begin{array}{c}86.52 \pm 9.09 \\
\text { (b) }\end{array}$ & $\begin{array}{l}100.50 \pm 18.56 \\
(b, c)\end{array}$ & $\begin{array}{c}77.75 \pm 6.01 \\
\text { (c) }\end{array}$ \\
\hline $\begin{array}{l}\text { Real size } \\
\text { (b) }\end{array}$ & $\begin{array}{c}86.21 \pm 8.02 \\
(\mathrm{a}, \mathrm{c})\end{array}$ & $\begin{array}{l}87.39 \pm 13.02 \\
\text { (a) }\end{array}$ & $\begin{array}{l}96.82 \pm 5.44 \\
\text { (a) }\end{array}$ & $\begin{array}{c}72.74 \pm 9.83 \\
(\mathrm{a}, \mathrm{c})\end{array}$ & $\begin{array}{l}80.63 \pm 11.85 \\
\text { (a) }\end{array}$ & $\begin{array}{c}68.92 \pm 7.46 \\
\text { (c) }\end{array}$ \\
\hline $\begin{array}{l}\text { F5 } \\
\text { (c) }\end{array}$ & $\begin{array}{c}104.54 \pm 5.99 \\
\text { (b) }\end{array}$ & $\begin{array}{c}100.26 \pm 6.55 \\
(0)\end{array}$ & $\begin{array}{l}108.16 \pm 7.40 \\
\text { (a) }\end{array}$ & $\begin{array}{l}87.85 \pm 13.05 \\
\text { (b) }\end{array}$ & $\begin{array}{l}85.50 \pm 12.39 \\
\text { (a) }\end{array}$ & $\begin{array}{c}111.14 \pm 9.80 \\
(\mathrm{a}, \mathrm{b})\end{array}$ \\
\hline $\begin{array}{l}\text { Literature value } \\
\text { (mean) }\end{array}$ & 95 (DIN 68364) & 120 (DIN 68364) & $120($ DIN 68364) & 95 (DIN 68364) & 105 (DIN 68364) & $\begin{array}{l}106 \text { (Wagenführ } \\
2007 \text { ) }\end{array}$ \\
\hline
\end{tabular}

The letter/digit in exclamation marks shows the specimen size (group) this specimen size differs from (statistically significant).

0 means that this specimen size is not statistically significantly different from any other specimen size.

\section{Bending strength}

The bending strength values of beech were in most cases superior to that of the other species, whereas lime normally showed the lowest values (Table IV). In contrast to that, the F5 lime specimens had the highest bending strength of all the $\mathrm{F} 5$ specimens with a mean value of $111.14 \mathrm{~N} / \mathrm{mm}^{2}$. This was due to a drastically higher raw density in this group (mean $0.72 \mathrm{~g} / \mathrm{cm}^{3}$ ). The standard deviation in most groups was small.

Compared to literature (Table IV):

- standard maple mean values were considerably higher,

- with $120.64 \mathrm{~N} / \mathrm{mm}^{2}$ beech values were comparable to literature values,

- birch, oak and ash showed lower values, and

- lime showed values by far lower.

Regarding the size effect, for all species, the bending strength decreased as the specimen's dimensions were increased. The results back two statements of Denzler (2007). First, there is a direct influence of the specimen's height on the bending strength of defect-free specimens. Denzler (2007) explains that due to the test standards, specimen height and length (span) are normally multiples of one another. Thus, the mentioned height effect can rather be defined as a combined size effect of specimen height and length (span). Whether the specimen height contributes more to this size effect or the specimen length (span) is in most publications not considered. Madsen and Tomoi (1991), though, designed a set-up to answer especially this question and concluded that a consistent height effect was not present, but a substantial length (span) effect. The second statement of Denzler (2007), which is backed by the results of this study, is the fact that as long as the specimens are kept defect-free, the specimen width has no influence on the bending strength (Bohannan 1966, Denzler 2007, Madsen and Tomoi 1991). Since a direct size effect occurs, Weibull's theory (1939) applies for the bending tests of this study.

In literature, a lot of controversy on the matter of size effect can be found. Denzler (2007) explains the results of the different authors in the most comprehensive way. Again, Schneeweiß and Felber (2013) provide a list of publications on the matter with some explanations.

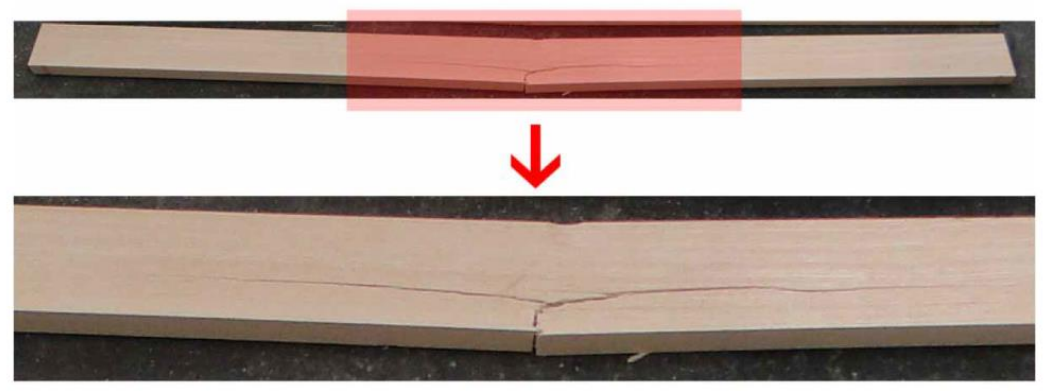

Figure 3. Typical bending testing failure mode with wrinkles in compression zone and T-break in tension zone. The specimen shown here is an ash Real size specimen. 
The failure mode of the Standard specimens and the F5 specimens was similar for all species. As explained in Madsen (1992), typically, the upper part of the specimen experiences compression stress (compression zone), to which it reacts quite ductile with compression wrinkles (i.e. failure), before the lower side under tension fails suddenly (brittle) with a weak formation of a typical T-break (mixed mode of failure: tension perpendicular and parallel to grain; Figure 3). The Real size specimens showed the same sequence of events. It has to be stated, though, that here, clear differences in the failure modes of the different species can be found. While ash and beech showed tension failure similar to that of the Standard specimens (weak to pronounced T-break in tension zone; Figure 3), oak and maple failed very brittle, mostly breaking into many little pieces. Lime and birch form very pronounced wrinkles in the compression zone (buckling of fibers), before the tension zone fails quite ductile. The more stress is applied, the more little fiber bundles are torn apart, resulting in many scattered little $\mathrm{T}$ breaks.

During the testing, it was observed that the F5 specimens had a tendency to tilt to the side - a movement referred to as 'lateral torsional buckling'. Whenever this movement influenced the $F_{\max }$ values, in other words, the specimens fell over before $F_{\max }$ was reached, the test was declared void. Per species, this happened in one to six cases. In the birch group, one-third of the tests were invalid. This 'lateral torsional buckling' did not present a problem in the Real Size group, which have the same length-to-width-to-height ratio as the F5 specimens. This could be due to either a size effect or the slightly different test set-up of both groups. For Real size testing, all support pins and the compression die were fixed, while for F5, one support pin and the compression die were movable, which makes the specimens more susceptible to tilting. Furthermore, the production of the very little F5 specimens can
Effect of size and geometry on strength values

be seen as one source of error. In the F5 specimens, already a slight deviation from a right angle causes the specimens to tilt to the side. Therefore, the width-to-height ratio of the F5 specimens (0.3) is not recommended for little defect-free specimens.

\section{Tensile strength}

Tensile strength values varied greatly (Table V). The mean values ranged from $39.45 \mathrm{~N} / \mathrm{mm}^{2}$ (lime Real size) to $160.50 \mathrm{~N} / \mathrm{mm}^{2}$ (birch Standard). In general, birch and beech Standard specimens attained the highest strength values. Compared to literature (Table V):

- the birch value was considerably higher than the one DIN 68364 (2003) provides,

- the attained maple mean strength was again higher than the literature value,

- oak $\left(73.46 \mathrm{~N} / \mathrm{mm}^{2}\right)$ and ash $\left(97.13 \mathrm{~N} / \mathrm{mm}^{2}\right)$ showed much lower values than the German standard, and

- the lime mean value was with $104.69 \mathrm{~N} / \mathrm{mm}^{2}$ considerably higher than the value Wagenführ (2007) presents.

In this study, a clear statement of the effect of specimen size on tensile strength is not possible. For that, a number of explanations can be listed. First, this is due to the drastic differences in selected specimen shapes (Standard versus Real size and F5). Second, testing set-ups of Real size and F5 specimen testing were not optimal (see failure mode description below). Third, the production of the bone-shaped Standard specimen is very likely to influence the strength values, due to cutting into the fibers, when routering the taper. This led to a (in most cases) very high standard deviation (coefficient of variation for ash $38.03 \%$ ). Still, the bone shape of the Standard specimens represents the optimal way of force transmission. Thus, the Standard mean strength values were always significantly higher. Further research is

Table V. Tensile strengths derived from defect-free specimens of different sizes - Mean \pm SD $\left[\mathrm{N} / \mathrm{mm}^{2}\right]$.

\begin{tabular}{|c|c|c|c|c|c|c|}
\hline Specimen size & Maple & Birch & Beech & Oak & Ash & Lime \\
\hline $\begin{array}{l}\text { Standard } \\
\text { (a) }\end{array}$ & $\begin{array}{c}140.65 \pm 23.49 \\
(b, c)\end{array}$ & $\begin{array}{c}160.50 \pm 44.58 \\
(b, c)\end{array}$ & $\begin{array}{c}128.18 \pm 25.17 \\
(b, c)\end{array}$ & $\begin{array}{c}73.46 \pm 16.10 \\
(\mathrm{~b}, \mathrm{c})\end{array}$ & $\begin{array}{c}97.13 \pm 36.94 \\
\text { (b) }\end{array}$ & $\begin{array}{c}104.69 \pm 27.21 \\
(\mathrm{~b}, \mathrm{c})\end{array}$ \\
\hline $\begin{array}{l}\text { Real size } \\
\text { (c) }\end{array}$ & $\begin{array}{c}48.73 \pm 13.84 \\
(a, c)\end{array}$ & $\begin{array}{c}68.73 \pm 6.38 \\
\text { (a) }\end{array}$ & $\begin{array}{c}93.68 \pm 12.59 \\
\text { (a) }\end{array}$ & $\begin{array}{c}60.41 \pm 13.04 \\
\text { (a) }\end{array}$ & $\begin{array}{c}75.12 \pm 5.67 \\
\text { (a) }\end{array}$ & $\begin{array}{c}39.45 \pm 6.56 \\
\text { (a) }\end{array}$ \\
\hline $\begin{array}{l}\text { F5 } \\
\text { (b) }\end{array}$ & $\begin{array}{c}82.65 \pm 4.73 \\
(a, b)\end{array}$ & $\begin{array}{c}100.17 \pm 14.10 \\
\text { (a) }\end{array}$ & $\begin{array}{l}100.80 \pm 10.41 \\
\text { (a) }\end{array}$ & $\begin{array}{c}57.17 \pm 9.45 \\
\text { (a) }\end{array}$ & $\begin{array}{c}87.85 \pm 14.70 \\
(0)\end{array}$ & $\begin{array}{c}50.74 \pm 10.45 \\
\text { (a) }\end{array}$ \\
\hline $\begin{array}{l}\text { Literature value } \\
\text { (mean) }\end{array}$ & 120 (DIN 68364) & 137 (DIN 68364) & 135 (DIN 68364) & $110(\mathrm{DIN} 68364)$ & $\begin{array}{c}130 \text { (DIN } \\
68364)\end{array}$ & $\begin{array}{l}85 \text { (Wagenführ } \\
2007 \text { ) }\end{array}$ \\
\hline
\end{tabular}

The letter/digit in exclamation marks shows the specimen size (group) this specimen size differs from (statistically significant). 0 means that this specimen size is not statistically significantly different from any other specimen size. 


\section{$8 \quad$ P. Schlotzhauer et al.}

needed with adjusted specimen sizes and shapes) (also bone shapes for the F5 and Real size specimens) to be able to make precise size effect statements for indigenous hardwoods. Especially for testing at real size, this means very high timber consumptions.

Concerning the failure mode, the Standard specimens failed very brittle in the center of the specimens. The simple board shape of the F5 and Real size specimens in most cases led to fracture in the clamping area. Based on these findings, the test set-up for real size specimens proposed by Blaß et al. (2005) should be employed with special care. Only when a certain knot size (or any other wood-debilitating characteristic) is exceeded, interpretation of the results makes sense. Below that characteristic knot size (etc.), the obtained strength values originate from the fracture induced in the clamping area. That characteristic knot size (etc.) threshold for a useful value is different for every species.

For defect-free specimens, Schneeweiß and Felber (2013) mention a strong decrease in tensile strength when increasing the length of the specimens and list a series of publications from 1925 to 1980 to back the statement. Again, these findings originate from softwood studies. The strong influence of the specimen length cannot be proved by this study, but results indicate that the specimen cross-section (width and depth) are minor influence factors compared to the influence of the clamping/jaws and wood characteristics like grain deviation.

\section{MOE}

Regarding the moduli of elasticity (MOE), for compression and bending testing, it was observed that for all species, the specimen's dimensions did not influence their MOE values. Therefore, Table VI only lists the mean values of the Standard specimens. Literature normally lists the bending MOE. Thus, Table VI also lists the mean bending MOE literature values:

- for maple, birch and lime, this study's values are higher than the ones of literature,

- for lime, study values are with $13,058 \mathrm{~N} / \mathrm{mm}^{2}$, about double the literature values,
- oak and ash values lie around $10,000 \mathrm{~N} / \mathrm{mm}^{2}$ and therefore are considerably lower than literature values $\left(13,000 \mathrm{~N} / \mathrm{mm}^{2}\right)$, and

- beech shows values similar to literature.

For maple and birch - very light colored species with little contrast - the contact-free camera system for elongation recording delivered distorted results. Especially in F5 and Standard3 compression testing, this shortcoming of the contact-less system in combination with a very little recording distance (area) led to sporadically very high MOE values up to 75,000 $\mathrm{N} / \mathrm{mm}^{2}$ (birch). Thus, the standard deviation of birch is with $9911 \mathrm{~N} / \mathrm{mm}^{2}$ very high (Table VI). For bending testing, this problem did not occur, since here no contrast but the distance between the specimen and a reference point was measured.

During the actual testing procedure, it was observed that the F5 compression specimens were too thin in comparison to their length (see failure mode description above), and so buckling occurred. According to the Euler buckling cases, case two was detected. It was concluded that the later MOE results should be interpreted with special care, since the resulting MOE would be a result of compression and buckling. In most cases, no significant difference between the four groups could be detected, which contradicted this temporary hypothesis. As explained earlier, another special phenomenon occurred in the Standard compression testing of lime. Here, the top and bottom parts, which were in direct contact with the metal plates, widened (bulge formation), because the short fibers were pressed together and so the specimen's height was reduced (Figure 2(a)). Thus, no further compression stress could be induced into the specimen, resulting in distorted strain measurements. It seems like this phenomenon is more pronounced when the cross-section is rather big compared to the specimen length (long. direction). Further testing is needed to evaluate this phenomenon and its influence on the MOE values of different size specimens.

So far, little literature addresses the effect specimen size has on MOE values. Only Madsen (1992) summarizes some of his research concerning the influence of span length in bending testing on MOE values. $\mathrm{He}$

Table VI. MOE values of defect-free Standard specimens - Mean \pm SD $\left[\mathrm{N} / \mathrm{mm}^{2}\right]$.

\begin{tabular}{lllllll}
\hline Test & \multicolumn{1}{c}{ Maple } & \multicolumn{1}{c}{ Birch } & \multicolumn{1}{c}{ Beech } & Oak & Ash & Lime \\
\hline Compression & $14,172 \pm 3582$ & $22,206 \pm 9911$ & $15,867 \pm 3845$ & $9496 \pm 1573$ & $11,589 \pm 2669$ & $14,686 \pm 3486$ \\
Bending & $12,206 \pm 870$ & $15,792 \pm 931$ & $13,708 \pm 1223$ & $10,096 \pm 1190$ & $10,231 \pm 2132$ & $13,058 \pm 1120$ \\
Tension & $14,401 \pm 2400$ & $18,591 \pm 1141$ & $13,411 \pm 1591$ & $10,370 \pm 1581$ & $9822 \pm 2145$ & $14,809 \pm 2748$ \\
Literature value & 10,500 & 14,000 & 14,000 & 13,000 & 13,000 & 7400 \\
$\quad$ (mean bending MOE) & (DIN 68364) & (DIN 68364) & (DIN 68364) & (DIN 68364) & (DIN 68364) & (Wagenführ 2007) \\
\hline
\end{tabular}


states that values increase dramatically with increasing span and that this is caused by an unknown phenomenon.

Regarding the tensile $M O E$, the statistical analysis detected a size effect for almost all species. Whether the MOE differences are due to a real size effect or rather caused by differences in specimen shapes and differing distances between the elongation measuring points and the force introduction area cannot be answered conclusively by this study. Here, also further research is needed with adjusted specimen sizes, shapes and machine set-ups.

\section{Disclosure statement}

No potential conflict of interest was reported by the authors.

\section{References}

Astrup, T., Clorius, C. O., Damkilde, L. and Hoffmeyer, P. (2007) Size effect of glulam beams in tension perpendicular to grain. Wood Science Technology, 41, 361-372.

Blaß, H. J., Denzler, J., Frese, M., Glos, P. and Linsemann, P. (2005) Biegefestigkeit von Brettschichtholz aus Buche Karlsruher Berichte zum Ingenieurholzbau Band 1 (Karlsruhe: Universitätsverlag Karlsruhe). p. 137.

Bohannan, B. (1966) Effect of Size on Bending Strength of Wood Members. U.S. Forest Service Research Paper FPL 56 (Madison, WI: Forest Products Laboratory).

Buchelt, B. and Pfriem, A. (2011) Influence of wood specimen thickness on its mechanical properties by tensile testing: solid wood versus veneer. Holzforschung, 65, 249-252.

Burger, N. (1998) Einfluss der Holzabmessungen auf die Festigkeit von Schnittholz unter Zugbeanspruchung in Faserrichtung. Dissertation (Aachen, Germany: Shaker-Verlag).

Denzler, J. K. (2007) Modellierung des Größeneffekts bei biegebeanspruchtem Fichtenschnittholz. Dissertation (Munich, Germany: Technische Universität München).

DIN 52182. (1976) Testing of wood; determination of density

DIN 52183. (1977) Testing of wood; determination of moisture content.

DIN 52185. (1976) Testing of wood; compression test parallel to grain.

DIN 52186. (1978) Testing of wood; bending test.

DIN 52188. (1979) Testing of wood; determination of ultimate tensile stress.

DIN 68364. (2003) Properties of wood species - Density, modulus of elasticity and strength.
DIN EN 14081. (2012) Timber structures - Strength graded structural timber with rectangular cross section - Part 1: General requirements.

EN 408. (2003) Timber structures - Structural timber and glued laminated timber - Determination of some physical and mechanical properties.

Hoffmeyer, P., Damkilde, L. and Pedersen, T. N. (2000) Structural timber and glulam in compression perpendicular to grain. Holz als Roh- und Werkstoff, 58, 73-80.

Madsen, B. (1992) Structural Behaviour of Timber (Vancouver, Canada: Timber Engineering Ltd.), p. 405.

Madsen, B. and Tomoi, M. (1991) Size effects occurring in defectfree spruce-pine-fir bending specimens. Canadian fournal of Civil Engineering, 18 (4), 637-643.

Oehmichen, K., Demant, B., Dunger, K., Grüneberg, E., Hennig, P., Kroiher, F., Neubauer, M., Polley, H., Riedel, T., Rock, J., Schwitzgebel, F., Stümer, W., Wellbrock, N., Ziche, D. and Bolte, A. (2011) Inventurstudie 2008 und Treibhausgasinventar Wald (Braunschweig: Landbauforschung, Sonderheft 343, vTI).

Okohira, Y., Masuda M. and Suzuki, N. (1989) The size effect of compressive strength of wood. Bulletin of the Faculty for Bioresources, 2, 13-21.

Pedersen, M. U., Clorius, C. O., Damkilde, P. and Hoffmeyer, P. (2003) A simple size effect model for tension perpendicular to grain. Wood Science and Technology, 37 (2), 125-140.

Schneeweiß, G. (1964) Druckfestigkeit und Stempelhärte. Holz als Roh- und Werkstoff, 22 (7), 258-264.

Schneeweiß, G. and Felber, S. (2013) Review on the bending strength of wood and influencing factors. American fournal of Materials Science, 3 (3), 41-45.

Seintsch, B. and Weimar, H. (2012) Actual situation and future perspectives for supply and demand of hardwood in Germany. In R. Németh and A. Teischinger (eds.) The 5th Conference on Hardwood Research and Utilisation in Europe. Proceedings of the "Hardwood Science and Technology" - the 5th Conference on Hardwood Research and Utilisation in Europe. September 10-11, Sopron, pp. 301312.

Showalter, K. L., Woeste, F. E. and Bendtsen, B. A. (1987) Effect of Length on Tensile Strength in Structural Lumber. U.S. Forest Service Research Paper FPL-RP-482. (Madison, WI: Forest Products Laboratory).

Smith, I., Landis, E. and Gong, M. (2003) Fracture and Fatigue in Wood (Chichester: John Wiley \& Sons Ltd.), p. 234.

Wagenführ, R. (2007) Holzatlas (Munich, Germany: Carl Hanser Verlag GmbH \& Co. KG), p. 816.

Weibull, W. (1939) A statistical theory of the strength of material. The Royal Swedish Institute for Engineering Research, Proceedings No. 151, Stockholm, pp. 1-45. 


\section{Paper f}

Critical discussion of perpendicular to grain tension testing of structural timber - case study on the European hardwoods ash, beech and maple 


\title{
Critical discussion of perpendicular to grain tension testing of structural timber - case study on the European hardwoods ash, beech and maple
}

\author{
Philipp Schlotzhauer, Alexander Ehrmann, Susanne Bollmus and Holger Militz \\ Wood Biology and Wood Products, Georg-August-University of Göttingen, Lower Saxony, Germany
}

ABSTRACT

Knowledge about perpendicular to grain tension behavior of wood is essential, since in construction tension stresses perpendicular to grain cannot be avoided completely. Especially for hardwoods, the data basis is scarce. EN 338 design values are with $0.6 \mathrm{~N} / \mathrm{mm}^{2}$ characteristic strength set very low. The US-American National Design Specifications even set this value to zero and make local reinforcements mandatory. This paper compares strength and stiffness values attained with newly-designed, little, prismatic specimens and EN 408 structural timber specimens to evaluate the current European design values. Little specimen's characteristic strength values range from 7.2 to $10.6 \mathrm{~N} / \mathrm{mm}^{2}$ and are assumed to be real material properties. EN 408 specimen values are with approximately $4.0 \mathrm{~N} / \mathrm{mm}^{2}$ lower. These lower values are mainly due to stress peaks introduced by the force introduction. Strength values attained for the medium-dense European hardwoods beech, ash and maple exceed EN 338 design values by a factor of six to seven. Adaptation of the EN 338 design value is not recommended, though. The abundance of influencing factors makes clear that the design value and the ensuing design code have to be synchronized carefully by tedious testing in order to make use of the perpendicular to grain tension strength potential of the selected hardwoods.
ARTICLE HISTORY

Received 8 May 2018

Revised 13 March 2019

Accepted 13 March 2019

KEYWORDS

Hardwoods; strength; stiffness; perpendicular to grain; design value; tension; test set-up; EN 338

\section{Introduction}

Since central European hardwood availability is rising constantly and softwood availability is declining, politicians and scientists have been working towards a raised utilization of hardwoods in the building sector. In the last decade, numerous Europe-wide research efforts resulted in a number of new products on the market. For each one of these products a set of strength, stiffness and density values are stated in the corresponding documents. For glulam products, these values can be found in technical building approvals (national and European). The basis for the technical building approval for beech glulam has been set by Blaß et al. (2005). The research basis for the approvals for other hardwood glulam products (oak, sweet chestnut, beech LVL) followed - mainly financed by private companies. For structural timber (not glued), EN 338 (2016) supplies the values, with which the engineer calculates and designs wooden elements of a building. The so-called Eurocode 5 (DIN EN 1995-1-1 2010), the standard package for timber construction, gives the design rules. According to EN 1912 (2013) the species ash, beech, maple, oak, poplar and sweet chestnut can be used as structural timber after visual strength grading according to national visual strength grading standards has been carried out. The basis for this has mainly been set by Glos and Näher (2005) and Glos and Torno (2008). To the knowledge of the authors, machine strength grading settings, which are defined in a so-called ITT-report, only exist for sweet chestnut at present. At the moment - except of glulam made of beech LVL (BauBauche) - no hardwood building product is used intensively in construction.
In contrast to softwood, the data basis for European hardwoods for construction usage is very limited. If a greater integration of hardwoods into the building sector is to succeed, this knowledge has to be raised. It is known that single hardwoods possess certain characteristics extremely superior to those of softwoods respectively the mainly used spruce (Picea abies L.) lumber (e.g. compression strength perpendicular to grain). Since characteristics as well as the ratios between the characteristics can vary strongly between the different hardwoods, for each hardwood species the set of characteristics stated in EN 338 (2016) needs to be determined separately.

Perpendicular to grain tension strength is the lowest of all strength characteristics stated in EN 338 (2016). Knowledge about perpendicular to grain tension properties of structural timber is essential, since it is not possible to avoid these stresses completely in construction. They appear everywhere, where loads are applied at an angle $\left(>0^{\circ}\right)$ to the grain, especially in the ridge of sloped and curved beams (particularly pitched-tapered), connections, openings (holes) and notches (Ehlbeck 1985, Blaß and Schmid 2001, Hübner 2013). Here the raised perpendicular to grain tension strength of hardwood could be economically advantageous, when expensive local reinforcements can be avoided.

\section{Values}

In EN 338 (2016) the calculation values for building with softand hardwood structural timber are given. Here, characteristic

CONTACT Philipp Schlotzhauer pschlot1@gwdg.de - Wood Biology and Wood Products, Georg-August-University of Göttingen, Lower Saxony 37077,

Germany

(1) 2019 Informa UK Limited, trading as Taylor \& Francis Group 
perpendicular to grain tension strength is set to the value 0.6 $\mathrm{N} / \mathrm{mm}^{2}$ for all strength classes from D18 to D70. The forme German standard DIN 1052 (2008) gave an even lower value of $0.5 \mathrm{~N} / \mathrm{mm}^{2}$ for both soft- and hardwoods. Although the EN 338 (2016) distinguishes between soft- and hardwoods with a $50 \%$ higher value for hardwoods, the calculation value is still estimated to be very conservative (Van de Kuilen 2016). Hunger and Van de Kuilen (2015) analyze the perpendicular to grain tension test data of Westermayr (2014) and propose that EN 338 (2016) strength values should be raised and mean stiffness should be adjusted. The German technical building approval for beech glulam also sets the characteristic perpendicular to grain strength very low with $0.5 \mathrm{~N} / \mathrm{mm}^{2}$. Mean and 5 -percentile stiffness are with 690 and $550 \mathrm{~N} / \mathrm{mm}^{2}$ lower than in EN 338 (2016), where the mean stiffness ranges from 730 to $860 \mathrm{~N} / \mathrm{mm}^{2}$ for beech, ash and maple.

The scientific literature on perpendicular to grain tension properties of European hardwoods is scarce. The following Table 1 lists the literature values available on the three target species of this study - European ash, maple and beech. The values are listed in a descending order of the mean strength values.

Due to several influencing factors, strength and stiffness values under tension perpendicular to grain vary greatly.

\section{Influencing factors}

The following section summarizes the influencing factors on perpendicular to grain tension strength and stiffness. These factors also interact with each other. Therefore, when interpreting the data and when applying values in building design, special care must be taken. Other factors like the original location in the tree (horizontally and vertically), the tree origin, the drying process and the duration of load (and others) also effect strength and stiffness. Therefore, when listing test results, info on these factors should also be listed.

\section{Density and moisture content}

Kollmann (1956) emphasizes the importance of specimen density and moisture content on the perpendicular to grain characteristics. Testing little, error-free specimens of a variety of species, he concludes that with rising densities strength values also rise. Blaß and Schmid (1998), who tested structural timber, do not find a density-strength relationship. Regarding the wood moisture content, following Kollmann (1956) a 1\% rise in wood moisture content leads to strength loss of $1.5-2 \%$. Ożyhar (2013) describes a similar relationship for the stiffness of beech wood.

\section{Specimen geometry, size and force introduction}

Perpendicular to grain tension testing of structural timber and glulam is described in EN 408 (2012). Further details can be found in EN 1193 (1998). The specimen geometry and the test set-up is mainly based on the work of Ehlbeck and Kürth (1994), who also give an overview of the existing standards respectively specimens and test set-ups to determine perpendicular to grain tensile strength (and modulus of elasticity respectively MOE) of structural timber and glulam. The structural timber specimens differ in their geometry and the force introduction (see Table 2). There are three main specimen geometries: double-notched, bone-shaped and prismatic specimens. The force is either introduced directly through (clamping) jaws (like in tension testing parallel to grain) or via metal plates and/or other wood members, which are glued on and/or screwed to the test specimen.

Ehlbeck and Kürth (1994) summarize the assets and drawbacks of each of the existing test methods. They confirm the statement of Kollmann (1951) and Markwardt and Youngquist (1956) that in any double-notched specimen local stress peaks are formed. The occurring stresses are hardly analyzable. This

Table 1. Available literature values of perpendicular to grain tension testing of European ash, maple and beech at $12 \%$ moisture content.

\begin{tabular}{|c|c|c|c|c|c|c|c|c|}
\hline \multirow[b]{2}{*}{ Species } & \multicolumn{2}{|c|}{ Strength } & \multicolumn{2}{|c|}{ MOE } & \multirow[b]{2}{*}{ Specimen geometry - force introduction } & \multirow[b]{2}{*}{ Literature } & \multirow{2}{*}{$\begin{array}{l}\text { Annual ring } \\
\text { orientation }\end{array}$} & \multirow[b]{2}{*}{ Further specifications } \\
\hline & Mean & 0.051 & Mean & 0.05 & & & & \\
\hline \multirow[t]{4}{*}{ Ash } & 11.0 & & & & Prismatic - Clamping & Keylwerth (1951) & Tang. & Little, error-free \\
\hline & 6.12 & 2.97 & 1070 & 705 & Prismatic - glued on metal plates & Westermayr (2014) & $\begin{array}{l}\text { All directions } \\
\text { (tang., rad., } 45^{\circ} \text { ) }\end{array}$ & Real size, error-free \\
\hline & 3.0 & & & & Double-notched & Keylwerth (1951) & Tang. & Little, error-free \\
\hline & 2.93 & 1.58 & 1115 & 898 & $\begin{array}{l}\text { Prismatic - glued on longitudinal wood } \\
\text { member }\end{array}$ & Hübner (2013) & All & $\begin{array}{l}\text { Real-size glulam with } \\
\text { errors }\end{array}$ \\
\hline \multirow[t]{3}{*}{$\begin{array}{l}\text { Maple (Acer } \\
\text { saccharum) }\end{array}$} & 10.4 & & & & Double-notched & $\begin{array}{l}\text { Kretschmann and Mascia } \\
\text { (2016) }\end{array}$ & Rad. & Little, error-free \\
\hline & 8.4 & & & & & $45^{\circ}$ & & \\
\hline & 5.3 & & & & & Tang. & & \\
\hline \multirow[t]{10}{*}{ Beech } & 19.5 & & 1510 & & Bone-shaped (both-sided) - clamping & Ożyhar (2013) & Rad. & Little, error-free \\
\hline & $\sim 17.7$ & & & & Bone-shaped (necked) - clamping & Goulet (1960) & Rad. & Little, error-free \\
\hline & 12.6 & & & & Bone-shaped (necked) - clamping & Kollmann (1956) & Rad. & Little, error-free \\
\hline & 10.5 & & & & Prismatic - clamping & Keylwerth (1951) & Tang. & Little, error-free \\
\hline & $\sim 10.3$ & & & & Bone-shaped (necked) - clamping & Goulet (1960) & Tang. & Little, error-free \\
\hline & $\begin{array}{l}\sim 8.89 \\
\text { (Ameri }\end{array}$ & ican b & $\begin{array}{r}\sim 929 \\
\text { beech) }\end{array}$ & & Bone-shaped (necked) - clamping & Ellwood (1954) & Tang. & Little, error-free \\
\hline & 8.9 & & 730 & & Bone-shaped (both-sided) - clamping & Ożyhar (2013) & Tang. & Little, error-free \\
\hline & 5.61 & 3.08 & 966 & 663 & Prismatic - glued on metal plates & Westermayr (2014) & $\begin{array}{l}\text { All directions } \\
\text { (tang., rad., } 45^{\circ} \text { ) }\end{array}$ & Real-size, error-free \\
\hline & 3.88 & 2.08 & 1212 & 1096 & $\begin{array}{l}\text { Prismatic - glued on longitudinal wood } \\
\text { member }\end{array}$ & Hübner (2013) & All & $\begin{array}{l}\text { Real-size glulam with } \\
\text { errors }\end{array}$ \\
\hline & 3.1 & & & & Double-notched & Keylwerth (1951) & Tang. & Little, error-free \\
\hline
\end{tabular}


makes them unsuitable for perpendicular to grain strength determination of structural timber. Furthermore, the validity of values is questionable, since specimens are very little compared to structural timber. A possible size effect may affect the values. Strain measurements are not intended or possible in these specimens. Strain measurements are generally possible in bone-shaped (necked) specimens, when the parallel measurement length is sufficient. In that parallel measurement area, an even stress distribution is attainable (Kollmann 1951, Ehlbeck and Kürth 1994). Their drawbacks are that the production of 'perfect' (error-free) specimens is close to impossible, what makes the results questionable. Due to their little size, the informative value for structural timber is also limited. Prismatic specimens are easy to produce, but force introduction presents a challenge. Glued on metal plates or wooden members hinder transverse contraction and produce multiaxial stresses and stress peaks, what leads to failures close to the glued edges. This makes the attained strength values hard to interpret (Blaß and Schmid 2001, Pedersen et al. 2003). Strain measurement is possible, as long as measurements are taken at a certain distance from force introduction. The present specimen and test set-up of the EN 408 (2012) is based on a proposal by Larsen (1987) for a prismatic specimen with glued on metal plates (Ehlbeck and Kürth 1994). They also state that by integrating (gluing) two longitudinal (axial) pieces of wood between the prismatic test specimen and the two metal plates, stress peaks are reduced. Gluing on the metal plates or even metal plates and longitudinal pieces of wood is a rather difficult task with frequent occurrence of defective bonds as consequence. Schniewind and Lyon (1973) present an easier alternative, where specimens are loaded directly via clamping jaws. Attaining crack free specimens of the desired height presents a challenge for all above mentioned prismatic specimens.

In the presented literature, bone-shaped (necked) solid wood specimens give the highest strength values followed by prismatic and double-notched specimens. As explained above, this is mainly owed to the distribution of stresses in the different specimen types. Comparing the results attained with prismatic specimens by Westermayr (2014) and Hübne (2013) reveals the influence the specimen size has on the tension strength perpendicular to grain. With the bigger glulam specimens with allowed strength reducing flaws Hübner (2013) achieves strength values half (ash) respectively two third (beech) of the Westermayr (2014) values. Weibull's (1939) size effect theory explains the lower values with the higher probability of encountering strength reducing errors (flaws) in bigger specimens.

\section{Annual ring orientation and crack formation}

The influence of the annual ring orientation in the specimen respectively the loading direction is also undisputed. Goulet (1960), for example, tested bone-shaped, little and error-free beech specimens and reports mean strength values of $17.7 \mathrm{~N} / \mathrm{mm}^{2}$ for loading in the radial direction and $10.3 \mathrm{~N} /$ $\mathrm{mm}^{2}$ in the tangential direction. The lower strength in the tangential direction is owed to the anatomic structure of the beech wood namely the low strength of the medullary rays and micro-cracks formed during the drying process or already in the standing tree (Kollmann 1956, Niemz 2005, Westermayr 2014, Kretschmann and Mascia 2016). Generally, drying cracks are formed in the direction of the medullary rays due to the swelling and shrinking anisotropy of wood i.e. highest shrinkage rate in the tangential direction (Kollmann 1956). Thus, the effect of drying cracks on the mechanical properties of wood members depend on respectively interact with the annual ring orientation in the wood member. Changes in environmental conditions have a big effect on cracking and therefore the final strength and stiffness under short- and long-term loading.

Perpendicular to grain MOE is not considered by most of the literature presented in Table 1. The values available for beech and ash are similar between the species, but the variation within the species groups is high (Hübner 2013, Ożyhar 2013, Westermayr 2014).

\section{Aim of study}

EN 338 (2016) perpendicular to grain characteristic strength values for hardwoods and values presented by scientific literature differ extremely. Therefore, it is the goal of this study to test structural timber according to EN 408 (2012) and EN

Table 2. Possible specimen types for perpendicular to grain tension testing

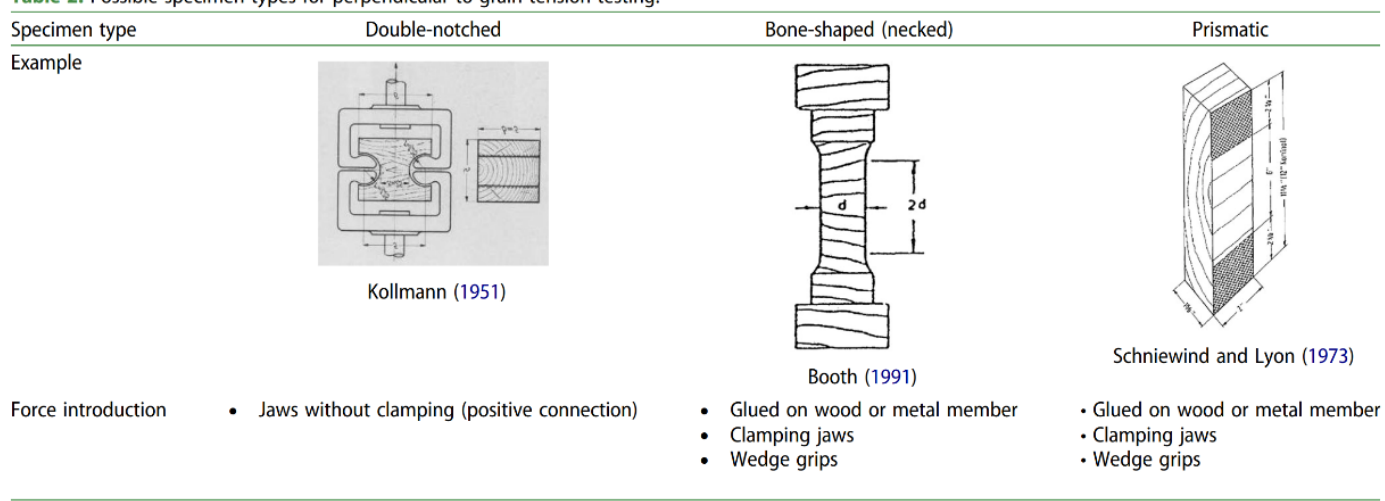


384 (2016) specifications and discuss the values. The prismatic specimen type of the EN 408 (2012) is criticized by a series of authors (Blaß and Schmid 2001, Pedersen et al. 2003, Westermayr 2014), because attained values are negatively influenced by stress peaks introduced by glued on metal plates for force introduction. For this study, a new specimen shape for perpendicular to grain tension testing of structural timber is designed. The data gathered is used to evaluate, if the newly designed specimen (and test set-up) is suitable as alternative to the difficult to produce present EN 408 (2012) specimen.

This paper contributes to the overall goal of supplying data for an increased use of hardwood in construction. As research material, the three European hardwood species maple (Acer pseudoplatanus L.), ash (Fraxinus excelsior L.) and beech (Fagus sylvatica L.) were chosen. The applicability of beech wood in construction is contemporarily constantly under discussion, due to the tree's wide availability, which in Central Europe is expected to grow in the future (Sauter 2016). Ash and maple have only recently been introduced into the EN 1912 (2013) list of species of strength-graded structural timber, based on the work of Glos and Torno (2008). Data on their perpendicular to grain tension characteristics is hardly present, though.

\section{Material and methods}

For this study, specimens were produced in accordance with EN 408 (2012) to the final dimensions of $70 \times 180 \times 45 \mathrm{~mm}^{3}$ (long. $\times$ rad./tang. $\times$ tang./rad.). As specified by the standard EN 384 (2016), the specimens were produced without any strength reducing characteristics (flaws). The standard also states that the testing sample (set of specimens) must be representative for the full spectrum of growth regions, densities and growth rates. This condition is not met by this study, since the selected species are at present not marketed as structural timber. Thus, no typical assortment is available, for which a typical distribution of properties could be determined. The research material originated from B quality round logs (according to RVR 2015) from South-West Germany that were live-sawn. In order to evaluate a size respectively geometry effect or effect of force introduction system on strength and MOE values, a second, little specimen is tested. In Europe, no standard for tension testing little, errorfree specimens perpendicular to grain is available. Thus, a prismatic specimen of the cross-section $20 \times 20 \mathrm{~mm}^{2}$ and the length $180 \mathrm{~mm}$ was designed (see Figure 1). The selected cross section is equivalent to that of the little, error-free specimens described in DIN 52192 (1979) for compression testing perpendicular to grain.

To ensure comparability of results, for each EN 408 specimen (big) two $20 \times 20 \mathrm{~mm}^{2}$ cross-section specimens (little) were produced from the axially adjacent wood section in the plank ("axially assigned"). As Figure 2 shows, from the area adjacent to each big specimen two little specimens could be produced. For maple 68 big specimens (resulting in 136 little specimens) were produced, for ash 66 big specimens (respectively 132 little specimens) and for beech 85 big specimens (170 little specimens).

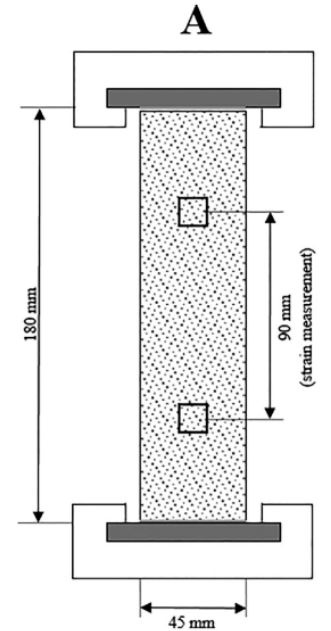

B

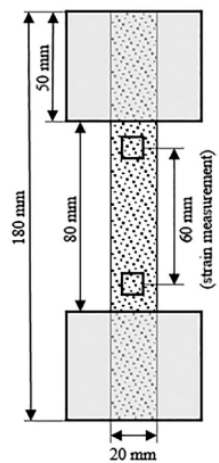

Figure 1. Schematic drawing of specimens (with speckle-pattern) and force introduction systems for (A) big EN 408 specimen and (B) little, newly designed specimen ("sub-set B").

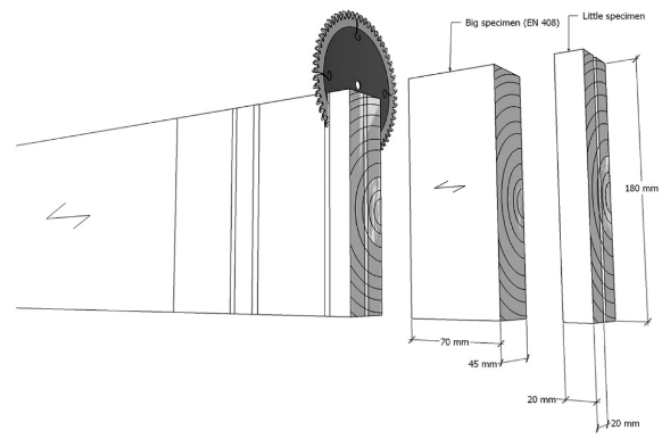

Figure 2. Cutting scheme of production of big (EN 408) and little specimens from original plank.

The specimens were sorted according to their annual ring orientation (Figure 3), following the classification proposed by Blaß and Schmid (1998).

After conditioning to the equilibrium moisture content in $20^{\circ} \mathrm{C}$ and $65 \%$ relative humidity, the specimens were uniformly
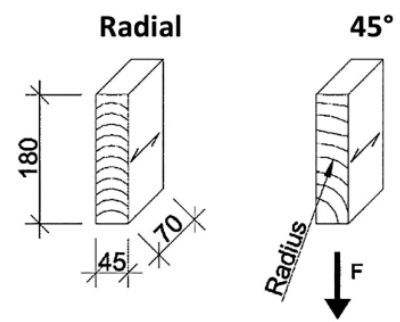

Tangential

Figure 3. Classification after annual ring orientation in the specimens proposed by Blaß and Schmid (1998). 
loaded with a $100 \mathrm{kN}$ universal testing machine at constant environmental conditions (static short-term loading). Into the big (EN 408) specimens the force is introduced according to EN 408 (2012) specifications. Here a $10 \mathrm{~mm}$ thick meta plate is glued to both $45 \times 70 \mathrm{~mm}$ planes of each specimen with a 2-component epoxy glue. Preliminary testing of six different 2-component epoxy glues revealed that the majority of glues is not applicable due to insufficient strength, resulting in premature glue-line failures. Finally, a gluing system was identified, which performed satisfactory (Araldite 2011 GB resin, Huntsman). The main difference between the different size specimens, next to the changed geometry, is the force introduction system. While into the big specimens the force is introduced through the metal plates and the glue-line, in the little specimens simple clamping in longitudinal (axial) direction introduces the testing force.

The tests were carried out with a speed of $0.3 \mathrm{~mm}$ per minute (strain-controlled) for the big specimens and $0.7 \mathrm{~mm}$ per minute for the little specimens, aiming for times to failure of $300 \pm 120 \mathrm{~s}$ for the big and $90 \pm 30 \mathrm{~s}$ for the little specimens. According to the standard EN 408 (2012), strength values attained with EN 408 specimens are only valid, when at least $80 \%$ of the failure is located outside the bond. The strain (displacement) was measured on one side of each specimen with a contact-free system (camera system VideoXtens, Zwick/Roell). For this purpose, prior to testing a speckle-pattern was sprayed on one axial plane (end-grain) of each specimen. Measurement distance for the big specimens was $90 \mathrm{~mm}$. For the little specimens, the set was divided into two sub-sets, since for each big specimen two little specimens were produced. In "sub-set A" strain was measured at a distance of $40 \mathrm{~mm}$, in "sub-set B" this distance was set to $60 \mathrm{~mm}$. In all cases, one side of the force introduction was mounted spherically.

\section{Results}

Table 3 summarizes the results of the presented test series under tension stress loaded perpendicular to the grain. The little specimens are divided into two subsets with different strain measurement distances -60 and $40 \mathrm{~mm}$. Below the results of the entire EN 408 (all) specimen set, for each species one further set is specified. This set only contains the specimens, which meet the EN 408 (2012) requirement that less than $20 \%$ of the failure area lie in the glue line (EN 408 valid).
The values relevant for a discussion of the EN 338 design strength values are the EN 408 (valid) figures, which are highlighted in Table 3. For the three tested species, these values are similar and range from $3.76 \mathrm{~N} / \mathrm{mm}^{2}$ for maple to $4.24 \mathrm{~N}$ / $\mathrm{mm}^{2}$ for beech. The low number of valid specimens especially for beech $(n=14)$ - makes the value little robust. For maple and ash, approximately half of the test sample was evaluated as valid. Not considering the EN 408 (2012) glue line failure requirements results in lower characteristic strength values. The coefficient of variance $(\mathrm{CoV})$ is for all species the highest for the EN 408 (all) group. The little specimens attain strength values that are much higher than the EN 408 (all and valid) groups' values. For both, mean and 5-percentile values, maple achieves the highest strength followed by beech and ash.

Mean MOE values $\left(E_{t, 90}\right)$ in the different groups of one species show little to no differences - regardless of specimen size or measuring distance. While ash values are slightly lower, beech and maple show comparable values (1.2-1.34 kN/ $\mathrm{mm}^{2}$ ). The variability in MOE values is high (CoV $\left.=21-43 \%\right)$, what leads to low 5-percentile values. For the species ash, the 5-percentile MOE value is the lowest. Comparing the little specimen sample with the EN 408 sample, beech and ash show lower 5-percentile values for the little specimens.

\section{Discussion}

\section{Influencing factors}

As explained above, perpendicular to grain tensile strength and stiffness values depend on a series of factors. Below, the results are analyzed and are discussed for the different factors separately.

Density and moisture content

It was intended to keep densities and moisture contents between the different specimen types indifferent to make sure strength and stiffness differences between specimen types (groups) are not due to differences in density or moisture content (see Figure 4).

Regarding the densities, the three different groups do not show significant differences for any species, which excludes the possible influence of density differences on stiffness and strength values. This is an effect of the cutting scheme ("axially assigned") of the specimens (see Figure 2).

\begin{tabular}{|c|c|c|c|c|c|c|c|c|}
\hline & Specimen & $n$ & $\begin{array}{l}\mathrm{f}_{\mathrm{t}, 90, \text { mean }} \\
{\left[\mathrm{N} / \mathrm{mm}^{2}\right]}\end{array}$ & $\begin{array}{c}\mathrm{CoV} \mathrm{f}_{\mathrm{t}, 90} \\
{[\%]}\end{array}$ & $\begin{array}{c}\mathrm{f}_{\mathrm{t}, 90,0.05} \\
{\left[\mathrm{~N} / \mathrm{mm}^{2}\right]}\end{array}$ & $\begin{array}{l}\mathrm{E}_{\mathrm{t}, 90, \text { mean }} \\
{\left[\mathrm{kN} / \mathrm{mm}^{2}\right]}\end{array}$ & $\begin{array}{c}\operatorname{CoV} E_{t, 90} \\
{[\%]}\end{array}$ & $\begin{array}{c}E_{t, 90,0.05} \\
{\left[\mathrm{kN} / \mathrm{mm}^{2}\right]}\end{array}$ \\
\hline \multirow{4}{*}{ Maple } & Little $(60 \mathrm{~mm})$ & 68 & 14.26 & 15.48 & 10.59 & 1.31 & 31.19 & 0.74 \\
\hline & Little $(40 \mathrm{~mm})$ & 68 & 14.15 & 19.06 & 10.40 & 1.34 & 30.05 & 0.73 \\
\hline & EN 408 (all) & 68 & 4.29 & 23.21 & 2.61 & 1.33 & 27.06 & 0.77 \\
\hline & EN 408 (valid) & 32 & 4.92 & 14.60 & 3.76 & 1.30 & 27.73 & 0.79 \\
\hline \multirow[t]{4}{*}{ Beech } & Little $(60 \mathrm{~mm})$ & 85 & 11.01 & 27.66 & 7.28 & 1.20 & 24.90 & 0.84 \\
\hline & Little $(40 \mathrm{~mm})$ & 85 & 12.12 & 25.86 & 8.07 & 1.27 & 21.19 & 0.88 \\
\hline & EN 408 (all) & 84 & 3.52 & 44.64 & 0.84 & 1.33 & 21.87 & 0.98 \\
\hline & EN 408 (valid) & 14 & 5.31 & 12.02 & 4.24 & 1.23 & 22.35 & 0.97 \\
\hline \multirow[t]{4}{*}{ Ash } & Little $(60 \mathrm{~mm})$ & 31 & 9.47 & 17.29 & 7.19 & 1.17 & 42.51 & 0.45 \\
\hline & Little $(40 \mathrm{~mm})$ & 66 & 9.25 & 16.07 & 7.16 & 1.18 & 39.02 & 0.45 \\
\hline & EN 408 (all) & 66 & 4.09 & 32.89 & 1.52 & 1.21 & 34.47 & 0.59 \\
\hline & EN 408 (valid) & 34 & 5.04 & 12.75 & 4.04 & 1.21 & 34.41 & 0.59 \\
\hline
\end{tabular}



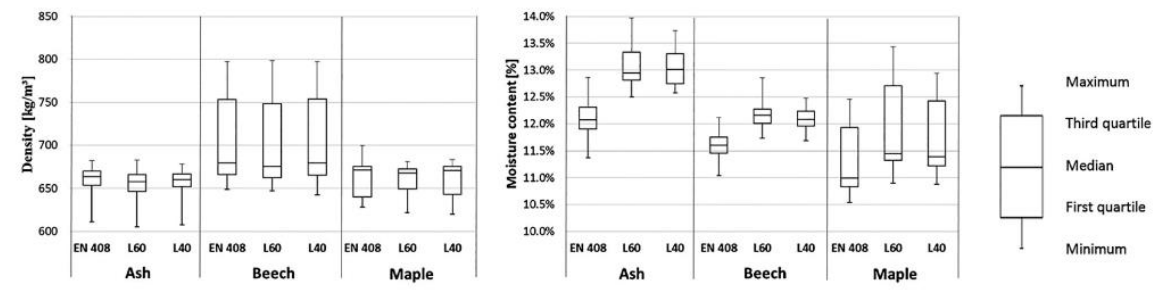

Figure 4. Boxplots of density and moisture content separated after species and specimen size respectively MOE measurement distance $(L 60=l i t t l e, 60 \mathrm{~mm} ; \mathrm{L} 40=$ little, $40 \mathrm{~mm}$ ).

The density's influence on strength values of little errorfree specimens (E40 and E60) is shown in Figure 5 for beech.

The coefficient of determination $\left(R^{2}\right)$ for the best-fit linear regression line is with $0.37 \mathrm{low}$. The regression line has a negative slope. The density-stiffness relationship is comparably low $\left(R^{2}=0.23\right)$. Maple correlations are with $R^{2}$ values for the density-strength-relationship of 0.65 and 0.74 for the density-stiffness-relationship higher. For maple, the regression line shows a positive slope, i.e. with rising density both strength and stiffness rise. This relationship is also observed for little error-free ash specimens. $R^{2}$ values, though, are lower (strength: 0.45; stiffness: 0.53).

The low $R^{2}$ values for ash and beech confirm the findings of Blaß and Schmid (1998) that report no correlation between perpendicular to grain strength and density. Kollmann's (1956) statement that perpendicular to grain tension strength rises with rising density cannot be confirmed. His findings, though, refer to the testing of many different species with highly different densities, while in this study each species is analyzed separately. In the present study, the described species-independent strengthdensity relationship may be superimposed by other underlying factors. Figure 5, for example, indicates a strong grouping effect of the annual ring orientation on density and strength. This effect is observed for all species for strength and stiffness. The density differences of the different groups are mainly due to the different original locations (horizontally) of the specimens in the tree. As Figure 6 indicates, it was only possible to produce unglued specimens that are loaded in the tangential direction from side cut boards. Here only mature wood can be found, which is

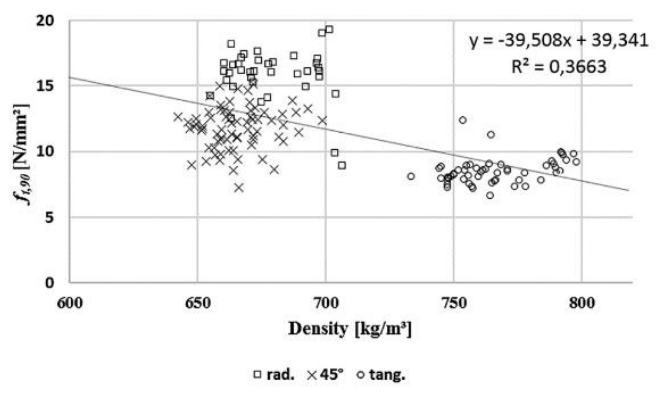

Figure 5. Density-strength-relationship for little error-free beech specimens separated after annual ring orientation. characterized by higher densities compared to juvenile wood. Specimens, which are loaded radially or at approximately $45^{\circ}$ contain mature as well as juvenile wood. Consequently, their mean densities are lower. It was also expected that strength and stiffness value variation would be higher for these collectives than for tangential specimens. This was clearly observed for maple and ash wood, but not for the tested beech samples (see Figure 7).

Moisture contents show differences between the little and the big EN 408 specimens, since they were tested at different times (see Figure 4). The biggest difference is observed for ash, where the median of the moisture content of the EN 408 group is about $1 \%$ lower $(12.1$ vs. $13.0 \%$ ) than that of the little specimens. As Table 3 depicts, for the species beech and ash the 5-percentile MOE values are slightly lower for the little specimens than for the EN 408 specimens, while the mean values are similar. Since this effect cannot be observed for maple, this difference is not likely to be due to the specimen geometry. Differences in density or annual ring orientation are not present due to the "axial assignment"

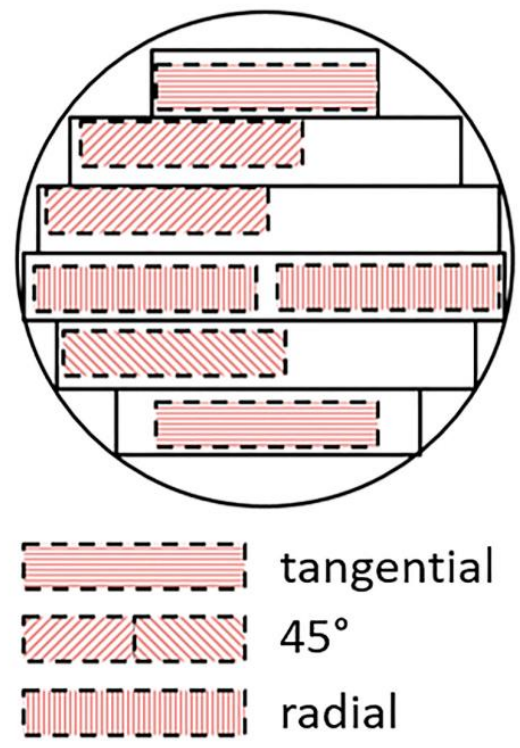

Figure 6. Horizontal location of different annual ring orientation specimens in the original log. 

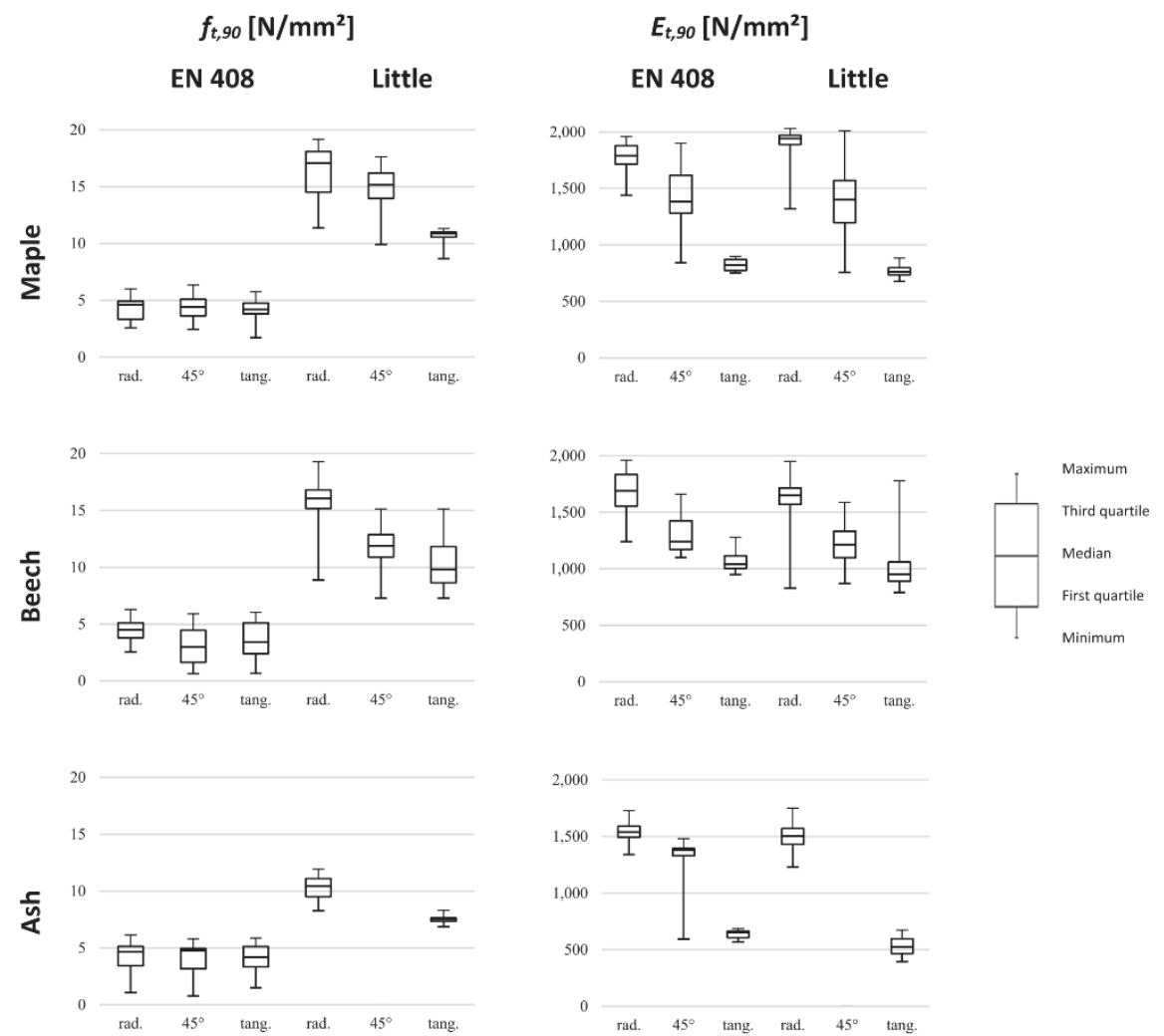

Figure 7. Boxplots showing the influence of annual ring orientation on the strength and stiffness of EN 408 and little perpendicular to grain tension specimens.

of the specimens (see Figure 4). Ożyhar (2013) describes for beech wood that a $1 \%$ MC change is accompanied by a relative stiffness change of approximately $2.5 \%$. Since the 5 -percentile value is very sensitive to changes in the lower value range, the $\mathrm{MC}$ differences reported here, are an explanation for the lower 5-percentile values in the little beech and ash specimens, compared to the EN 408 specimens. Kollmann (1956) reports a similar relationship between perpendicular to grain strength and MC (1.5-2\% strength change with $1 \%$ MC change). This hypothesis cannot be checked in this study, because the possible influence of MC differences is superimposed by other influencing factors.

Specimen geometry, size and force introduction

The two different specimen types of this study are next to geometry differences characterized by different force introduction systems. While in the little specimens, the force is introduced via clamping jaws, which are closed on the specimens in longitudinal (axial) direction, the big EN 408 specimens are loaded through glued on metal plates. With finite element calculations, Blaß and Schmid (2001) prove for EN 408 specimens the formation of stress peaks in the corners of the glue lines due to stiffness differences between the joining partners. In their specimens, an intermediate wood block oriented parallel to the grain reduces stiffness differences between the joining partners (wood perpendicular to grain - wood parallel to grain - metal plate). Still, failure moistly occurs near or in the glue lines. This is also the case in this study. Thus, the attained strength values are not "real" material characteristics. Similar results are reported by Pedersen et al. (2003). According to them, the stress peaks in the glue line corners appear, because the glued-on metal plates hinder the wood from contracting in the transverse direction (to loading).

The force introduction into the little specimens of this study through clamping introduces just enough force to avoid slipping out of the specimens during testing. No clamping marks were visible. Nonetheless, a considerable share of specimens of each species showed failure within the clamping area (maple $88 \%$, beech $77 \%$, ash $53 \%$ ). Rather than a consequence of clamping stresses, failure in these areas occurs due to stochastic reasons. $56 \%$ of the specimen length is located between clamps, only $44 \%$ of the total length presents the free testing length. Strength values of specimens that broke in the clamping areas are not different from the ones that fail within the free testing length. According to Kollmann (1956), only necked specimens give "real" perpendicular to grain material characteristics, although under certain 
conditions also prismatic specimens produce satisfactory results. This is achieved with the newly designed specimen, which is very easy to produce. Schniewind and Lyon (1973) that also tested prismatic specimens via clamping, report frequent failure in the clamping areas as well. Here, though, the force is introduced in the weaker radial/tangential direction and not axially, like in this study. Thus, the influence of clamping on strength values must be higher, because clamping produces clear clamping marks (i.e. compression failure perpendicular to grain), which introduces stress peaks into the transition zones between clamping and the free testing length.

Concerning the stiffness, no differences between the mean values of the EN 408 specimens and the little $(40$ and $60 \mathrm{~mm}$ measuring distance) specimens are found in this study. This means that, in the case of the little specimens, although strain measurements are taken at a close distance from the force introduction (at $60 \mathrm{~mm}$ measuring distance only $10 \mathrm{~mm}$ ), the clamping has no influence on the measurement Similar results are reported by Brabec et al. (2015) for compression testing parallel to grain. At a distance over $5 \mathrm{~mm}$ from the force introduction, stiffness measurement is not affected by force introduction anymore.

According to the standard EN 408 (2012), strength values attained with EN 408 specimens are only valid, when at least $80 \%$ of the failure is located outside the bond. This distinction leads to a different characteristic strength, since it makes sure that the attained strength value is not (or only little) influenced by possibly deficient bonding. Nonetheless, the resulting strength values are influenced by the force introduction system in a negative way. The low number of valid specimens (sample size), especially for beech $(n=14)$, makes the attained characteristic value little robust and emphasizes a further problem connected to the EN 408 specimen. Attaining bonds that exceed the load-bearing capacity of the wood member, is difficult. According to Weibull's weakest link theory, with growing volume, the possibility of the appearance of strength reducing flaws (checks, little knots, etc.) rises (Weibull 1939). Thus, the mean strength of the highe volume collectives will always be lower (stochastic explanation). This can - next to other factors - be an explanation for the lower strength of the EN 408 specimens. What effect exactly the volume difference (factor 7.88) of the different tested specimens has on the strength values, cannot be determined accurately with the selected test set-up, since force introduction is extremely different. Geometrical similarity, though, which according to Barrett (1974) is a prerequisite for a size effect analysis, is given in this study. Since stiffness does not differ for the different sizes, Weibull's weakest link theory as explanation of the observed size effect is questionable. A higher amount of strength reducing flaws, would obviously also influence stiffness. Other authors also doubt that the size effect observed in tension strength testing perpendicular to grain can exclusively be explained by Weibull's weakest link theory. Astrup et al. (2007) proves for spruce glulam that stress concentrations play an important role in the observed size effect. Pedersen et al. (2003) model (FE) the cylindrical orthotropy of wood to explain the observed strength (perpendicular to grain tension) size effect. They observe a simple maximum stress failure criterion, i.e. with growing size the stress inhomogeneity in the specimen increases, what leads to lower values. Barrett (1974) points out that the observed strength size effect has to be seen as a combination between volume, stresses and material quality. The implications for building design are always the same - allowable working stress must decline with size (Barrett 1974).

\section{Annual ring orientation and crack formation}

Many authors have emphasized the major influence of the annual ring orientation on perpendicular to grain characteristics (Baumann 1922, Kollmann 1956, Youngs 1957, Burgert et al. 1999). Therefore, for this study the annual ring orientation in the specimens was classified as proposed by Blaß and Schmid (1998). Figure 7 shows the influence the annual ring orientation has on the strength and stiffness values of the two different specimen types. While for the EN 408 specimens no influence of annual ring orientation on strength is shown, it has a significant influence on stiffness. For the little specimens, the annual ring orientation has a clear influence on both characteristics.

As in literature (Kollmann 1956, Goulet 1960, Burgert et al. 1999, Blaß and Schmid 2001, Kretschmann and Mascia 2016), the strength of specimens loaded in the radial direction is the highest. Stiffness values show the same trend. Absolute mean strength values stated by Kollmann (1956) for little, error-free necked beech specimens are with $12.6 \mathrm{~N} / \mathrm{mm}^{2}$ considerably lower than in this study. Goulet (1960) states for the same type specimen higher mean values of $17.7 \mathrm{~N} / \mathrm{mm}^{2}$. For beech specimens loaded tangentially, he reports the same values as this study $\left(10.3 \mathrm{~N} / \mathrm{mm}^{2}\right)$.

The lower strength in the tangential compared to the radial direction can be explained by the occurrence of micro drying cracks (checks), which form in the same direction as the medullary rays that also have a negative effect on strength in tangential testing (Kollmann 1956, Burgert et al. 1999, Kretschmann and Mascia 2016). In the radial direction, the rays have a strengthening effect, what is proved by Burgert et al. (1999) for living trees. A factor negatively influencing strength and stiffness in the radial direction is the occurrence of so-called shake (e.g. ring shake) due to growth anomalies in the living tree (Blaß and Schmid 1998).

The observation that the annual ring orientation has no influence on the strength values of big specimens may lead to a faulty interpretation. It is assumed that the force introduction system of the EN 408 specimens has such a strong effect on the strength values that it overlaps the effect the annual ring orientation has on the wood strength. Even for the EN 408 specimens that are evaluated as valid (less than $20 \%$ glue line failure), this effect is that strong that no influence of annual ring orientation can be seen. Mean MOE values $\left(E_{t, 90}\right)$ in the different groups of one species show no differences - regardless of specimen size or measuring distance. While ash values are slightly lower, beech and maple show comparable values $\left(1.2-1.34 \mathrm{kN} / \mathrm{mm}^{2}\right)$. Hübner (2013) and Westermayr (2014) present comparable results for ash. For beech, Hübner (2013) reports matching results, while the Westermayr (2014) mean value is lower. This is due to the fact that 
Westermayr (2014) mainly tested tangential and $45^{\circ}$ specimens, for which MOE values are comparatively low compared to specimens that are loaded in the radial direction. The variability in MOE values is high, which is also reported by Westermayr (2014), what leads to relatively low 5-percentile values.

Besides these theoretical considerations, as Figure 8 indicates, in structural timber the distinction of annual ring orientations becomes less clear with rising specimen height and/o width due to their circular arrangement around the pith (equalization effect). The described equalization effect explains why in timber engineering (structural timber and glulam) the different elastic behavior between radial and tangential loading is usually not considered. Also, the distinction between ring shake and drying cracks is not logic anymore at this size level.

\section{Implications on EN 338 design values}

Literature of the last 70 years shows (see Table 1) that the highest strength values are attained by necked respectively bone-shaped, little and error-free specimens. These values can be seen as "real" material properties. The analysis of the stress formation in double-notched specimens is close to impossible and thus attained values are hard to transfer to other material dimensions (Keylwerth 1951). As Kollmann (1956) already implies, special specimen and set-up designs of prismatic specimen testing can produce similar values to bone-shaped specimens. Consequently, values can also be "real" material properties. The values attained with the little prismatic specimens of this study are similar to those found by Keylwerth (1951) - also with prismatic specimens. They are also similar to the literature values, which are attained with bone-shaped specimens (Kollmann 1956, Goulet 1960, Ożyhar et al. 2013). Thus, these values can also be seen as "real" material properties, which can be transferred to other material dimensions.

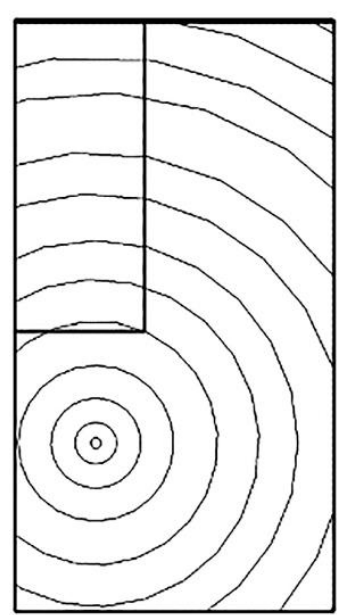

Figure 8. Influence of cross-section on annual ring orientation in timber.
The EN 408 specimens produce values that are heavily influenced (negative) by the stresses introduced by the force introduction. Westermayr (2014) also tested EN 408 specimens (test set-up slightly different: one glue-line in center of the wood member) and reports for the sample of valid ash and beech specimens marginally higher mean strength values than this study. 5-percentile values are higher in this study, though. Regarding perpendicular to grain tensile strength and stiffness - the values obtained for the hardwood species maple are comparable to those obtained for ash and beech by this and other studies. Hübner (2013) tested beech and ash glulam with errors (knots, pith, drying cracks etc.) and achieved lower mean and 5-percentile strength values (see Table 1). This emphasizes the importance of considering all influencing factors of a wood member's perpendicular to grain tension strength.

Concerning the strength design values provided by EN 338, the 5-percentile values obtained in this study for beech, maple and ash structural timber are six to seven times higher. Westermayr (2014) reports a factor of five for structural ash and beech timber and Hübner (2013) a factor of at least two for ash and beech glulam. Both authors as well as Hunger and Van de Kuilen (2015) propose a higher EN 338 design value. In fact, the EN 338 (2016) characteristic value of $0.6 \mathrm{~N} / \mathrm{mm}^{2}$ for perpendicular to grain tension strength seems very low and therefore prevents the calculating engineer to make use of this particular strength advantage. Nonetheless, a change is only then advisable, when a model is developed, which incorporates all influencing factors. For this purpose, further research is necessary. The establishment of a perpendicular to grain strength model, which considers all the above-mentioned factors (especially member size and geometry, moisture conditions, duration of load), can then be used to synchronize the EN 338 design value and the design code to a fitting set.

By setting perpendicular to grain strength to zero and making mechanical reinforcements mandatory, wherever perpendicular to grain tension stresses appear, the US-American National Design Specifications for Wood Construction (American Wood Council 2016) circumvent the described difficulties. On the one hand, this is the safest way to handle the challenging perpendicular to grain material characteristics on the other hand, the superior hardwood material potentials remain unused.

Attained stiffness values are similar for the two different type specimens tested in this study. Literature does not provide abundant data sets on perpendicular to grain tension stiffness values (see Table 1). The high stiffness variability, though, is stressed by all authors. This statement also holds for this study, where CoVs range from $21 \%$ to $43 \%$. Accordingly, 5-percentile values are very low. Looking at the design values stated in the EN 338 (2016), mean values for beech, ash and maple range from 730 to $860 \mathrm{~N} / \mathrm{mm}^{2}$ (D30 D40). These are by far exceeded by the attained values (1170-1340 N/mm²). In Eurocode 5 (DIN EN 1995-1-1 2010), only perpendicular to grain compression stiffness is important, when performing the serviceability check of contact connections (regarding perpendicular to grain deformations). For modeling the behavior of timber elements that experience 
perpendicular to grain tension stresses (e.g. due to connections, holes, etc.), reliable stiffness data is needed, which is provided by this paper.

\section{Conclusion}

Perpendicular to grain tension strength values (5-percentile) attained in this study with the EN 408 specimen are higher than EN 338 design strength value. Nonetheless, a need for a change of the EN 338 design value of medium-dense European hardwoods cannot be concluded only on the basis of the presented results. More important than the design value itself, are its implications on designing structures. The specimen design (shape, size and force introduction), the design value (EN 338), the design standard (Eurocode rules) and the assortments respectively grading (i.e. occurrence of cracks, knots, pith etc.) must be synchronized carefully. In construction situations, where perpendicular to grain strength is critical, the stresses, which are introduced into a wood member, need to be modeled prudently. Subsequently, it needs to be tested on real structures, if the applied models hold (short and long term) under different climatic conditions. According to the applied model, the EN 338 design value needs to be selected respectively adapted. These works are at present still missing.

It is the opinion of the authors that the ideal perpendicular to grain tension specimen should reflect the "real" materia properties and should, if possible, not be affected by an inhomogeneous stress distribution. Therefore, a prismatic specimen with axial clamping is suited better for strength determination on structural timber than the current EN 408 specimen with glued on metal plates. What also speaks for a substitution is the simple design and the easy production of such a specimen. In any case, it must be clear that the EN 338 design value does not reflect the "real" material property.

Perpendicular to grain tension stiffness (mean and 5-percentile) is higher in this study than the EN 338 design values. Both type specimens tested in this study allow MOE measurements. According to Eurocode 5 (DIN EN 1995-1-1 2010), the compression stiffness is important for building design. Tension stiffness is only important for modeling purposes, for which this paper provides useful data.

\section{Disclosure statement}

No potential conflict of interest was reported by the authors.

\section{References}

American Wood Council (2016) National Design Specification (NDS) for Wood Construction 2015 Edition (Leesburg: American Wood Council).

Astrup, T., Clorius, C. O., Damkilde, L. and Hoffmeyer, P. (2007) Size effect of glulam beams in tension perpendicular to grain. Wood Science and Technology, 41, 361-372.

Barrett, J.D. (1974) Effect of size on tension perpendicular-to-grain strength of douglas-fir. Wood and Fiber Science, 6, 126-143.

Baumann, R. (1922) Die Bisherigen Ergebnisse der Holzprüfungen in der Materialprüfungsanstalt an der Technischen Hochschule Stuttgart [The results of the wood tests at the Materials Testing Institute of the Technical University Stuttgart]. Forschungsarbeiten auf dem Gebiete des Ingenieurwesens (Berlin: Verlag des Vereines Deutscher Ingenieure), p. 139.

Blaß, H.J., Denzler, J., Frese, M., Glos, P. and Linsenmann, P. (2005) Biegefestigkeit von Brettschichtholz aus Buche [Bending strength of beech glulam] Band 1 Karlsruher Berichte zum Ingenieurholzbau (Karlsruhe: Universitätsverlag Karlsruhe), p. 137.

Blaß, H. J. and Schmid, M. (1998) Ermittlung der Querzugfestigkeit von Voll-und Brettschichtholz [Determinatin of perpendicular to grain tension strength of solid wood and glulam] (Stuttgart: Fraunhofer IRB Verlag), p. 262

Blaß, H. J. and Schmid, M. (2001) Querzugfestigkeit von Vollholz und Brettschichtholz [Perpendicular to grain tension strength of solid wood and glulam]. Holz als Roh- und Werkstoff, 58, 456-466.

Booth, L.G. (1991) Strength of timber in tension perpendicular to the grain: UK procedures past, present and future. Journal of the Institute of Wood Science, 12(3), 131-142.

Brabec, M., Tippner, J., Sebera, V., Milch, J. and Rademacher, P. (2015) Standard and non-standard deformation behaviour of European beech and Norway spruce during compression. Holzforschung, 69, 1107-1116.

Burgert, l., Bernasconi, A. and Eckstein, D. (1999) Evidence for the strength function of rays in living trees. Holz als Roh- und Werkstoff, 57, 397-399. DIN 1052 (2008) Design of Timber Structures - General Rules and Rules for Buildings (Berlin: German Institute for Standardization).

DIN 52192 (1979) Testing of Wood; Compression Test Perpendicular to Grain (Berlin: German Institute for Standardization).

DIN EN 1995-1-1 (2010) Eurocode 5: Design of Timber Structures - Part 1-1: General - Common Rules and Rules for Buildings (Berlin: German Institute for Standardization).

Ehlbeck, J. (1985) Möglichkeiten zur Erhöhung der Querdruck- und Querzugbelastbarkeit von Holz [Possibilities for increasing the perpendicular to grain compression and tension load-bearing capacity of wood]. Holz als Roh- und Werkstoff, 43, 105-109.

Ehlbeck, J. and Kürth, J. (1994) Ermittlung der Querzugfestigkeit von Vollund Brettschichtholz - Entwicklung Eines Prüfverfahrens [Determinatin of perpendicular to grain tension strength of solid wood and glulam development of a test method] (Stuttgart: Fraunhofer IRB Verlag), p. 60.

Ellwood, E. L. (1954) Properties of American Beech in Tension and Compression Perpendicular to the Grain and Their Relation to Drying (New Haven: Yale University), p. 82

EN 338 (2016a) Structural Timber - Strength Classes (Brussels: European Committee for Standardization).

EN 384 (2016b) Structural Timber - Determination of Characteristic Values of Mechanical Properties and Density (Brussels: European Committee for Standardization).

EN 408 (2012) Timber Structures - Structural Timber and Glued Laminated Timber - Determination of Some Physical and Mechanical Properties (Brussels: European Committee for Standardization).

EN 1193 (1998) Timber Structures - Structural Timber and Glued Laminated Timber - Determination of Shear Strength and Mechanical Properties Perpendicular to the Grain (Brussels: European Committee for Standardization).

EN 1912 (2013) Structural Timber - Strength Classes - Assignment of Visual Grades and Species (Brussels: European Committee for Standardization). Glos and Näher (2005) Aufnahme der Einheimischen Holzarten Buche (Fagus Sylvatica), Eiche (Quercus Petraea, Quercus Robur) und Douglasie (Pseudotsuga Menziesii) in die Europäische Norm EN 1912 [Inclusion of the native wood species beech, oak and douglas fir in the European standard EN 1912] (Munich: Technical University of Munich), p. 30.

Glos, P. and Torno, S. (2008) Aufnahme der Einheimischen Holzarten Ahorn, Esche und Pappel in die Europäische Norm EN 1912: "Bauholz Festigkeitsklassen - Zuordnung von Visuellen Sortierklassen und Holzarten [Inclusion of tha native wood species maple, ash and poplar in the European standard EN 1912: "Structural timber - Strength classes - Assignment of visual grades and species"] (Munich: Technical University of Munich), p. 73.

Goulet, M. (1960) Die Abhängigkeit der Querzugfestigkeit von EichenBuchen- und Fichtenholz von Feuchtigkeit und Temperatur im Bereich von $0^{\circ}$ bis $100^{\circ} \mathrm{C}$ [Dependence of perpendicular to grain tension strength of oak, beech and spruce wood on humidity and emperature in the range of $0^{\circ}$ to $100^{\circ} \mathrm{C}$. Holz als Roh- und Werkstoff, $18,325-331$. 
Hübner, U. (2013) Mechanische Kenngrößen von Buchen-, Eschen- und Robinienholz für Lastabtragende Bauteile [Mechanical parameters of beech, ash and locust lumber for load bearing members]. Doctoral thesis, (Graz: Technical University of Graz).

Hunger, F. and Van de Kuilen, J. W. (2015) Festigkeitsprofile von Heimischen Laubhölzern [Strength profiles of indigenous hardwoods] (Munich: Technical University of Munich), p. 58.

Keylwerth, R. (1951) Spalten, Spaltbeanspruchung und Querfestigkeit des Holzes [Splitting, splitting stresses and perpendicular to grain strength of wood]. Holz als Roh- und Werkstoff, 9 (1), 1-7.

Kollmann, F. (1956) Untersuchungen über die Querzugfestigkeit der Hölzer [Studies on perpendicular to grain tension strength of wood] (Munich: Technical University of Munich), p.15.

Kollmann, F. (1951) Technologie des Holzes und der Holzwerkstoffe Anatomie und Pathologie, Chemie, Physik, Elastizität und Festigkeit [Technology of wood and wood-based materials: anatomy and pathoogy, chemistry, physics, elasticity and strength] (Berlin: SpringerVerlag), p. 1050.

Kretschmann, D.E. and Mascia, N.T. (2016) Testing of small clear tension perpendicular to grain samples of sugar maple for radial, tangential and 45 degree loading orientation. World Conference on Timber Engineering 2016, 22-25 August 2016, Austria, Vienna.

Larsen, H. J. (1987) Determination of shear strength and strength perpendicular to grain. CIB-W18A paper 20-6-3, Dublin, Ireland.

Markwardt, L.J. and Youngquist, W.G. (1956) Tension Test Method for Wood, Wood-Base Materials, and Sandwich Constructions. U.S. Fores Service Research Paper FPL 2055 (Madison, WI: Forest Products Laboratory).

Niemz, P. (2005) Physik des Holzes. Vorlesungsskript [Wood physics. Lecture notes] (Zurich: ETH), p. 50.

Ożyhar, T. (2013) Moisture and time-dependent orthotropic mechanical characterization of beech wood. Doctoral thesis (Zurich: ETH).
Ożyhar, T., Hering, S., Sanabria, S. J. and Niemz, P. (2013) Determining moisture-dependent elastic characteristics of beech wood by means of ultrasonic waves. Wood Science and Technology, 47, 329-341.

Pedersen, M.U., Clorius, C.O., Damkilde, L. and Hoffmeyer, P. (2003) A simple size effect model for tension perpendicular to the grain. Wood Science and Technology, 37, 125-140.

RVR. (2015). Rahmenvereinbarung für den Rohholzhandel in Deutschland (RVR) [Framework agreement on raw timber trade in Germany] (Berlin: Deutscher Forstwirtschaftsrat \& Deutscher Holzwirtschaftsrat), p. 56.

Sauter, U. (2016) WP 1: Hardwood resources in Europe - Standing stock and resource forecasts. Presentation at workshop "European hardwoods for the building sector", 6 December 2016, Germany, GarmischPatenkirchen.

Schniewind, A. P. and Lyon, D. E. (1973) A fracture mechanics approach to the tensile strength perpendicular to grain of dimension lumber. Wood Science and Technology, 7, 45-59.

Van de Kuilen, J. W. (2016) Wood properties from roundwood to timber engineering. World Conference on Timber Engineering 2016, 22-25 August 2016, Austria, Vienna.

Weibull, W. (1939) A statistical theory of the strength of material. The Royal Swedish Institute for Engineering Research, Proceedings No. 151, Stockholm, pp. 1-45.

Westermayr, M. (2014) Querzugfestigkeit von Buchen- und Eschenholz Ermittlung von Kennwerten mittels DIN EN 408:2010 [Perpendicular to grain tension strength of beech and ash wood - determination of characteristic values according to DIN EN 408:2010]. Bachelor thesis (Munich: Technical University of Munich).

Youngs, R. L. (1957) The Perpendicular-to-Grain Mechanical Properties of red oak as Related to Temperature, Moisture Content, and Time. U.S. Forest Service Research Paper FPL 2079 (Madison, WI: Forest Products Laboratory). 


\section{Paper g}

(Published in the Conference transcipt of 6. Doktorandenkolloquium

Überprüfung der in DIN EN 338 angegeben

(Querdruck-)Festigkeits- und Steifigkeitseigenschaften sowie

Rohdichten für Buchen-, Eschen- und Ahornholz

[Review of EN 338 characteristic (perpendicular to grain compression) strength and stiffness as well as density values for European beech, ash and maple wood] 


\section{Überprüfung der in DIN EN 338 angegeben Festigkeits- und Steifigkeitseigenschaften sowie Rohdichten für Buchen-, Eschen- und Ahornholz}

\section{SCHLOTZHAUER PHILIPP}

M.Sc.

Wiss. Mitarbeiter

Abt. Holzbiologie \&

Holzprodukte

Georg-August-Universität

Göttingen

philipp.schlotzhauer@forst.uni-

goettingen.de

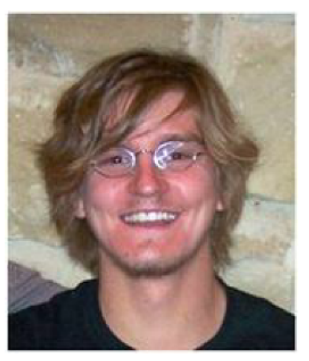

1985 geboren in Eisenach

2006-2012 Studium

Forstwissenschaften und

Waldökologie, Universität

Göttingen

Seit 2012 wissenschaftlicher Mitarbeiter in der AbtHolzbiologie \& Holzprodukte, Universität Göttingen

\section{Zusammenfassung}

Verfügbarkeitsaspekte, vorteilhafte elasto-mechanische Eigenschaften, sowie zum Teil offensives Marketing haben in den letzten Jahren zu einer Vielzahl an Forschungsvorhaben zum Thema „Laubholz für konstruktive Anwendungen“ und in deren Folge zu einigen bauaufsichtlichen Zulassungen geführt. Dabei sind ausgewählte Fragestellungen für spezielle Produkte beantwortet und geregelt worden. Allgemeine Materialkennwerte (charakteristische Werte und Mittelwerte) sind in der DIN EN 338 [1] für Nadel- und Laubholz angegeben. Im Zuge dieses Forschungsvorhabens sollen Festigkeits- und Steifigkeitseigenschaften, sowie Rohdichten der Laubhölzer Buche, Esche und Ahorn gemäß DIN EN 408 [2] nach Sortierklassen getrennt getestet und mit den in DIN EN 338 [1] angegebenen Werten verglichen werden.

Biegefestigkeiten wurden bis dato nur für fehlerfreies Material untersucht. Druckfestigkeiten parallel und rechtwinklig zur Faserrichtung wurden untersucht. Die Versuche zeigen, dass die Druckfestigkeit rechtwinklig zur Faserrichtung für die ringporige Esche nur eingeschränkt gemäß DIN EN 408 [2] zu bestimmen ist. Die Versuche zu den Schubfestigkeiten und den Zugfestigkeiten rechtwinklig zur Faserrichtung haben bis zum jetzigen Zeitpunkt noch keine eindeutigen Ergebnisse geliefert. Die Ergebnisse zu den Zugfestigkeiten parallel zur Faser für die in DIN 4074-5 [3] angegebenen Sortierklassen stehen noch aus.

\section{Einleitung}

Neuartige Waldbaukonzepte sehen zur Erhöhung und zum Schutz der Artenvielfalt in größtmöglichem Umfang Mischwälder vor. In den Niedersächsischen Landesforsten soll der gegenwärtige Laubholzanteil z.B. von $40 \%$ zukünftig auf $65 \%$ erhöht werden. Dementsprechend wird sich der Nadelholzanteil von derzeit $60 \%$ auf $35 \%$ verringern [4]. Jene Grundsätze ökologischer Waldbaukonzepte stehen im Widerspruch zum aktuellen Holzverbrauch in Deutschland. In der Sägeindustrie als wichtigster Rohholzabnehmer werden über $90 \%$ des Stammholzeinschnittes von Nadelholz gedeckt [5]. Nach Mantau [6] verbraucht auch die Holzwerkstoffindustrie mehr Nadelindustrieholz (34,1\%) als Laubindustrieholz (12,8 \%). 
Zukünftig wird es erforderlich sein, Laubholz in einem erhöhten Maß wirtschaftlich zu nutzen und potenzielle Wertschöpfungsketten und Anwendungsgebiete für dessen technischen Einsatz zu erschließen. Das Forschungsvorhaben „Schaffung neuer Absatzmärkte und Anwendungsfelder für einheimische Laubhölzer unter Anwendung neuartiger Technologien“ an der Universität Göttingen befasst sich mit dieser Thematik. Im Arbeitsschwerpunkt 1 „Verwendung von Laubholz für tragende Bauteile“ steht das Produkt Brettschichtholz (BSH) im Zentrum der Betrachtungen. Entlang der Produktionskette sollen drängende Fragestellungen analysiert und beantwortet werden. Welling [7] zählt eine Reihe von Gründen auf, warum bis dato Nadelholz der bevorzugte Rohstoff für stabförmige Holzbauprodukte ist. Geringe Abholzigkeit, gerade lange Stämme, homogene Sortimente, kleine i. d. R. gleichmäßig verteilte Äste, geringe Unterschiede physikalischer Eigenschaften zwischen den Nadelholzarten sowie gut vorhersagbare Eigenschaften begünstigen demnach die Verwendung von Nadelholz. Auf all diesen Gebieten sowie zusätzlich auch im Bereich der Verklebung weisen die einheimischen Laubhölzer Nachteile gegenüber den Nadelhölzern auf. Die erhöhten Rohdichten, Festigkeiten und Steifigkeiten jedoch sind Vorteile der Laubhölzer, die es zu nutzen gilt.

In den letzten 20 Jahren sind zahlreiche Forschungsvorhaben finanziert worden, um eine flächendeckende Nutzung von Laubhölzern im konstruktiven Bereich zu forcieren. Diese führten in einigen Fällen zu bauaufsichtlichen Zulassungen. Aicher [8] listet den aktuellen Stand der baurechtlich verwendbaren Brettschichtholz-Produkte aus Laubholz auf. Dazu gehören BSH aus Buche, Eiche, Edelkastanie sowie Buche-Furnierschichtholz. Diese Allgemeinen bauaufsichtlichen Zulassungen machen exakte Angaben zu Lamelleneigenschaften und Klebstoffen. Darüber hinaus finden sich dort Angaben zur Herstellung und Kennzeichnung der Träger sowie zu Entwurf und Bemessung. Allgemeine bauaufsichtliche Zulassungen sind notwendig, da Laubholz-BSH bis dato nicht gemäß europäischer Normen hergestellt werden kann. Ausgesuchte Laubholz-Vollholzprodukte dürfen jedoch nach europäischen Normen äquivalent zu Nadelholz hergestellt werden.

Im Allgemeinen gibt es für Holzprodukte die sog. Produktnorm, welche vorschreibt, wie das Holzprodukt zu fertigen ist. Für die verschiedenen Holzprodukte - Vollholz, keilgezinktes Vollholz, BSH, etc. - gibt es unterschiedliche Produktnormen. Die Bemessungsnorm DIN EN 1995-1-1 [9] gibt Planern bzw. Ingenieuren vor, wie Holzbauwerke zu bemessen sind. Die für die Berechnungen notwendigen Festigkeits-, Steifigkeits- und Rohdichtewerte sind in der DIN EN 338 [1] aufgeführt und werden in Festigkeitsklassen zusammengefasst. Hier sind sowohl Festigkeitsklassen für Nadelhölzer (C - coniferous) als auch für Laubhölzer (D deciduous) zu finden. Verschiedene Holzarten werden unterschiedlichen Festigkeitsklassen zugeordnet. Darüber hinaus können gleiche Holzarten unterschiedlicher Herkunft Festigkeitsunterschiede aufweisen. Auch unterschiedliche Sortierungen gleicher Holzarten (nach Astgrößen, Faserverläufen, Rohdichten, etc.) können zu Werteunterschieden führen. Beispiele nationaler visueller Sortierungen ausgewählter Hölzer und deren korrespondierende Festigkeitsklassen sind in der DIN EN 1912 [10] angegeben. Die DIN EN 14081-1 [11] gibt Anforderungen für maschinelle Sortierungen, damit diesen Festigkeitsklassen zugeordnet werden können. Die Bestimmung der Festigkeits-, Steifigkeits- und Rohdichtewerte zur Verifizierung der jeweiligen Zuordnung sind nach DIN EN 384 [12] zu ermitteln. Hier finden sich allgemeine Anweisungen zur Probennahme, Prüfungsdurchführung und -bedingungen sowie Berechnungsformeln. Für genaue Prüfanweisungen (z.B. Stützweiten, Prüfgeschwindigkeiten, Maßverhältnisse und ähnliches) zur Bestimmung physikalischer und mechanischer Eigenschaften wird auf die DIN EN 408 [2] verwiesen.

Zum einen haben Vorversuche gezeigt, dass einzelne Materialkennwerte für Laubhölzer nicht oder nur eingeschränkt entsprechend DIN EN 408 [2] zu bestimmen sind. Zum anderen sind 
die wissenschaftlichen Erkenntnisse zu Materialkennwerten einiger Laubhölzer bestimmter Provenienzen noch lückenhaft. Aus diesem Grund ist es ein Ziel dieses Forschungsvorhabens, die in der DIN EN 338 [1] angegebenen Materialkennwerte für die einheimischen Laubholzarten Buche, Esche und Ahorn zu bestimmen. Hierzu wird die Normenlage zu jeder einzelnen Prüfung analysiert, Literaturen zu der Thematik zusammengetragen und studiert, Materialprüfungen durchgeführt und deren Ergebnisse evaluiert. Wo es notwendig erscheint, werden Anmerkungen zu möglichen Optimierungen der Prüfungen vorgeschlagen. Dieses Vorgehen und die entsprechenden Ergebnisse werden in dieser Darstellung exemplarisch für den Materialkennwert Druckfestigkeit rechtwinklig zur Faser (inkl. E-Moduln und Rohdichten) durchgeführt.

\section{Druckfestigkeit rechtwinklig zur Faser}

\subsection{Normen- und Literaturlage}

Die Problematik „Querdruckprüfungen von Vollholz“ wurde in der Vergangenheit überwiegend für Nadelhölzer untersucht. Hierbei wurden verschiedenste Belastungssituationen \& Prüfkörperabmessungen (bzw. Ausformungen) geprüft. Diese Ergebnisse mündeten in Bemessungsmodellen, bei denen der Materialkennwert mit einem Querdruckbeiwert $\left(k_{\mathrm{c}, 90}\right)$ multipliziert wird. Auch andere Einflussfaktoren (Jahrringlage, Feuchte, sonstige Holzmerkmale und Bruchdefinition) auf die Druckfestigkeit und den EModul rechtwinklig zur Faser wurden analysiert. Die Untersuchungen wurden sowohl an Vollholz als auch an Brettschichtholz durchgeführt. Eine ausführliche Auflistung der bisherigen Forschungen auf diesem Gebiet listet Hübner [13] auf. Für Laubholz liegen ausschließlich Publikationen zu Brettschichtholz vor. Hübner [14] listet die Ergebnisse getrennt nach Holzart und Publikation. Für Buche liegen die charakteristischen Querdruckfestigkeiten zwischen $6,75 \mathrm{~N} / \mathrm{mm}^{2}$ und $8,4 \mathrm{~N} / \mathrm{mm}^{2}$, für Esche zwischen $6,75 \mathrm{~N} / \mathrm{mm}^{2}$ und 7,5 N/mm². Mittlere Querdruck-Elastizitätsmodul-Werte für Buche-BSH liegen je nach Publikation zwischen $690 \mathrm{~N} / \mathrm{mm}^{2}$ und $1040 \mathrm{~N} / \mathrm{mm}^{2}$. Für Esche liegen die Werte mit $1220 \mathrm{~N} / \mathrm{mm}^{2}$ und $1240 \mathrm{~N} / \mathrm{mm}^{2}$ näher beieinander. Aussagen über erreichte Stauchungen bei Erreichen der Querdruckfestigkeit $\left(f_{\mathrm{c}, 90, \mathrm{k}}\right)$ sind sehr unterschiedlich und zum Teil nicht angegeben. Wenn die Prüfung gemäß DIN EN 408 [2] durchgeführt wird, ist eine Stauchgrenze von $1 \%$ plastischer Verformung $\left(0,01 h_{0}\right)$ vorgegeben - ein Wert, bei dem je nach Elastizitätsmodul die absolute Stauchung unterschiedlich ausfällt (Abb. 1). Abweichend davon wird in der DIN 52192 [15] an kleinen, fehlerfreien Prüfkörpern die Druckfestigkeit bei einer plastischen Verformung von $2 \%$ bestimmt. Die Norm AITC-119 [16], welche in den USA Anwendung findet, gibt einen absoluten Wert für die Verformung bei der Druckfestigkeit an. Demnach gelten die Bemessungswerte für eine absolute Verformung von 0,04 inch $(1,016 \mathrm{~mm})$. Die hier angegebenen Bemessungswerte der Querdruckfestigkeiten für die nordamerikanischen Verwandten unserer einheimischen Buche und Esche (Fraxinus americana L., Fagus grandifolia Ehrh.) liegen bei 5,57 N/mm² [13]. 


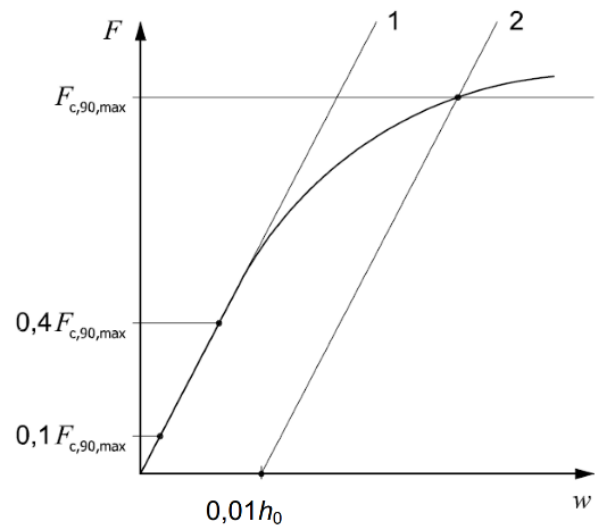

Abb. 1: Last-Verformungs-Diagramm für Querdruck nach DIN EN 408 [2]

Laut DIN EN 384 [12] gibt es ein „Alternativverfahren zur Bestimmung der mechanischen Eigenschaften". Hierbei wird die charakteristische Druckfestigkeit rechtwinklig zur Faserrichtung $\left(f_{\mathrm{c}, 90, \mathrm{k}}\right)$ gemäß folgender Gleichung errechnet:

$$
f_{c, 90, k}=0,015 \rho_{k}
$$

Die Formel zur Berechnung der Druckfestigkeit setzt einen Zusammenhang zwischen der charakteristischen Rohdichte $\left(\rho_{\mathrm{k}}\right)$ und der Druckfestigkeit voraus. Die DIN EN 338 [1] führt bei steigenden Festigkeitsklassen steigende Rohdichten und somit steigende Druckfestigkeiten rechtwinklig zur Faser an. Die konkreten Werte der DIN EN 338 [1] ergeben sich aus der Gleichung (1) und liegen zwischen 7,5 N/mm² (D18) und 13,5 N/mm² (D70). Dem hingegen wird in den bauaufsichtlichen Zulassungen für die Buche-BSH [17] und Eiche-BSH [18] die Druckfestigkeit $\left(f_{\mathrm{c}, 90, \mathrm{~g}, \mathrm{k}}\right)$ für alle Festigkeitsklassen einheitlich auf $8,4 \mathrm{~N} / \mathrm{mm}^{2}$ bzw. $8,0 \mathrm{~N} / \mathrm{mm}^{2}$ gesetzt, was einem Zusammenhang zwischen Rohdichte und Festigkeit widerspricht. Allerdings ist in den Zulassungen auch die Rohdichte konstant gesetzt, was auf Grund der Homogenisierung, den der Werkstoff durch seine Produktion (vom Vollholz zum BSH) erfährt, eine mögliche Vorgehensweise ist.

Äquivalent zur Druckfestigkeit rechtwinklig zur Faserrichtung wird in der EN 384 (2013) der E-Modul rechtwinklig zur Faserrichtung in Abhängigkeit zum E-Modul parallel zur Faserrichtung gesetzt:

$$
E_{90, \text { mean }}=E_{0, \text { mean }} / 15
$$

Auch hier zeichnen die bauaufsichtlichen Zulassungen zu BSH aus Buche und Eiche ein anderes Bild. Hier steigt mit steigender Festigkeitsklasse der E-Modul parallel zur Faserrichtung $\left(E_{0, \mathrm{~g}, 0,05}\right)$, der E-Modul rechtwinklig zur Faserrichtung ist jedoch konstant. Für die Buche werden für den Mittelwert $\left(E_{90, \mathrm{~g}, \text { mean }}\right) 690 \mathrm{~N} / \mathrm{mm}^{2}$ und für den charakteristischen Wert $\left(E_{90, \mathrm{~g}, 0,05}\right) 550 \mathrm{~N} / \mathrm{mm}^{2}$ angegeben. Hübner [13] deutet an, dass die Werte der 
Zulassungen auf einem wenig breiten Datenfundament stehen, was eine Erklärung für dieses Vorgehen sein könnte.

\subsection{Ergebnisse}

In der folgenden Darstellung werden die Ergebnisse der Querdruckfestigkeitsuntersuchungen (inkl. E-Moduln) an Vollholzprüfkörpern aus Ahorn, Buche und Esche an der Georg-AugustUniversität Göttingen dargestellt. Verschiedene Lastsituationen (zur Herleitung eines Bemessungsmodells) sind nicht Gegenstand der Prüfungen. Es wurde ausschließlich gemäß DIN EN 408 [2] geprüft und Werte gemäß DIN EN 384 [12] berechnet. Das bedeutet, dass die Werte $F_{\mathrm{c}, 90, \max }$ bei einer plastischen Verformung von $1 \%$ und der E-Modul in einem Bereich zwischen $0,1 F_{\mathrm{c}, 90, \max }$ und $0,4 F_{\mathrm{c}, 90, \max }$ ermittelt wurde (Abb. 1). Das Versuchsmaterial wurde aus $65 \mathrm{~mm}$ starker Blockware von hochqualitativen Stämmen erzeugt. Es entsprach den Anforderungen von DIN EN 384 [12], wonach die Prüfkörper frei von Eigenschaften sein müssen, welche eine Reduzierung der Festigkeit bewirken. Die Ergebnisse der Untersuchungen sind in Tabelle 1 dargestellt.

Tab. 1: Zusammenfassung der Ergebnisse der Querdruckversuche

\begin{tabular}{|c|c|c|c|c|}
\hline & Ahorn & Buche & \multicolumn{2}{|c|}{ Esche } \\
\hline $\begin{array}{l}\text { Bruchdefinition } \\
\left(\text { Def. } \mathrm{F}_{\max }\right)\end{array}$ & $\begin{array}{l}1 \% \text { plast. } \\
\text { Verformung }\end{array}$ & $\begin{array}{c}1 \% \text { plast. } \\
\text { Verformung }\end{array}$ & $\begin{array}{l}1 \% \text { plast. } \\
\text { Verformung }\end{array}$ & $\begin{array}{c}10 \% \\
\text { Kraftabfall }\end{array}$ \\
\hline Stichprobenanzahl & $\mathrm{n}=88$ & $\mathrm{n}=90$ & $n=39$ & $\mathrm{n}=84$ \\
\hline$f_{\mathrm{c}, 90, \text { mean }\left[\mathrm{N} / \mathrm{mm}^{2}\right]}$ & 9,25 & 9,34 & 6,44 & 7,47 \\
\hline$f_{\mathrm{c}, 90,0,05\left[\mathrm{~N} / \mathrm{mm}^{2}\right]}$ & 6,73 & 7,41 & 5,22 & 5,29 \\
\hline$E_{\mathrm{c}, 90, \text { mean }\left[\mathrm{N} / \mathrm{mm}^{2}\right]}$ & 304 & 360 & $(438)$ & 583 \\
\hline$E_{\mathrm{c}, 90,0,05\left[\mathrm{~N} / \mathrm{mm}^{2}\right]}$ & 192 & 259 & (358) & 358 \\
\hline$\rho_{\mathrm{c}, 90, \text { mean }\left[\mathrm{g} / \mathrm{cm}^{3}\right]}$ & 0,637 & 0,735 & $(0,611)$ & 0,618 \\
\hline$\rho_{\mathrm{c}, 90,0,05\left[\mathrm{~g} / \mathrm{cm}^{3}\right]}$ & 0,590 & 0,653 & $(0,534)$ & 0,540 \\
\hline
\end{tabular}

Während der charakteristische Wert $7,4 \mathrm{~N} / \mathrm{mm}^{2}$ für Buche im Bereich der oben genannten Literaturwerte für $\mathrm{BSH}$ liegt $\left(6,75-8,4 \mathrm{~N} / \mathrm{mm}^{2}\right)$, erreicht die Esche nur Werte bis zu $5,3 \mathrm{~N} / \mathrm{mm}^{2}$ (Literaturwerte Esche-BSH 6,75-7,5 N/mm²). Desweiteren ist zu bemerken, dass $1 \%$ plastische Verformung $\left(0,01 h_{\mathrm{o}}\right)$, welche die DIN EN 408 [2] als Bruchdefinition vorgibt, bei mehr als der Hälfte der Eschen Prüfkörper nicht erreicht wurde (39 von 84 Prüfkörpern). Zuvor trat ein deutlicher Kraftabfall ein. Als Prüfungsende bzw. alternative Bruchdefinition wurde nach Analyse des Bruchverhaltens ein Kraftabfall von 10 \% gewählt. Dieses Versagen ist auf den ringporigen Aufbau der Esche zurückzuführen und findet abhängig von der Jahrringlage statt. Bei einer Prüfung in tangentialer Richtung (stehende Jahrringe) gibt es üblicherweise kein Versagen der Gefäße bevor 1\% plastische Verformung erreicht wird. Es ist auffällig, dass der charakteristische Wert $\left(f_{\mathrm{c}, 90,0,05}\right)$ der Querdruckfestigkeit jedoch nur in geringem Maße von der Bruchdefinition abhängt. Nichtsdestotrotz wird eine Adaptierung der Bruchdefinition für verschiedene Hölzer vorgeschlagen. So könnte, wie in dieser Arbeit geschehen, für ringporige Hölzer ein Kraftabfall von $10 \%$ als Prüfungsende definiert werden.

Der mittlere Elastizitätsmodul liegt bei allen untersuchten Holzarten unter den angegebenen Werten in der Literatur (690-1240 N/mm²). Bei Ahorn liegen die Werte mit $304 \mathrm{~N} / \mathrm{mm}^{2}$ und bei Buche mit $360 \mathrm{~N} / \mathrm{mm}^{2}$ weit unter Literaturwerten im für Nadelhölzer üblichen Bereich. Bei Esche $\left(583 \mathrm{~N} / \mathrm{mm}^{2}\right)$ sind die Unterschiede weniger gravierend. Ob die Ursache hierfür in verschiedenen Prüfkörperabmessungen (Größeneffekt) oder aber in fehlerhaften Aufnahmen 
liegen, wird zurzeit an kleinen, fehlerfreien Prüfkörpern überprüft. Zum Beispiel wird untersucht, ob das zur Aufnahme der Stauchung verwendete Videoextensometer bei der sehr hellen und strukturarmen Ahornholzoberfläche fehlerhafte Werte liefern könnte. Als Ursache für niedrige E-Moduln wäre außerdem auch die Auswahl bestimmter Bretter (Rift, Halbrift, Seitenware) denkbar. Hübner [13] rät zur Vermeidung von Riftbrettern in Bereichen, in denen die Deformation möglichst gering gehalten werden soll. Das Versuchsmaterial dieser Untersuchungen stammt hauptsächlich aus Riftbrettern, da die Stärke der Prüfkörper $(45 \mathrm{~mm})$ mit der zum starken Verziehen neigenden Seitenware sonst schwer zu erzielen ist. Auffällig ist, dass die charakteristischen Werte $\left(E_{\mathrm{c}, 90,0,05}\right)$ noch sehr viel geringer sind als die Mittelwerte $\left(E_{\mathrm{c}, 90, \text { mean }}\right)$. Die 45 Prüfkörper, die bei der Esche eine plastische Verformung von $1 \%$ nicht erreicht haben, sondern zuvor einen Kraftabfall von $10 \%$ erlitten, hatten äquivalent zu den Querdruckfestigkeiten keinen Einfluss auf den charakteristischen Elastizitätsmodul.

Die ermittelten Rohdichtewerte entsprechen den Literaturwerten. Abbildung 2 zeigt, dass die Querdruckfestigkeit der Esche nur eine geringfügige Abhängigkeit von der Rohdichte erkennen lässt.

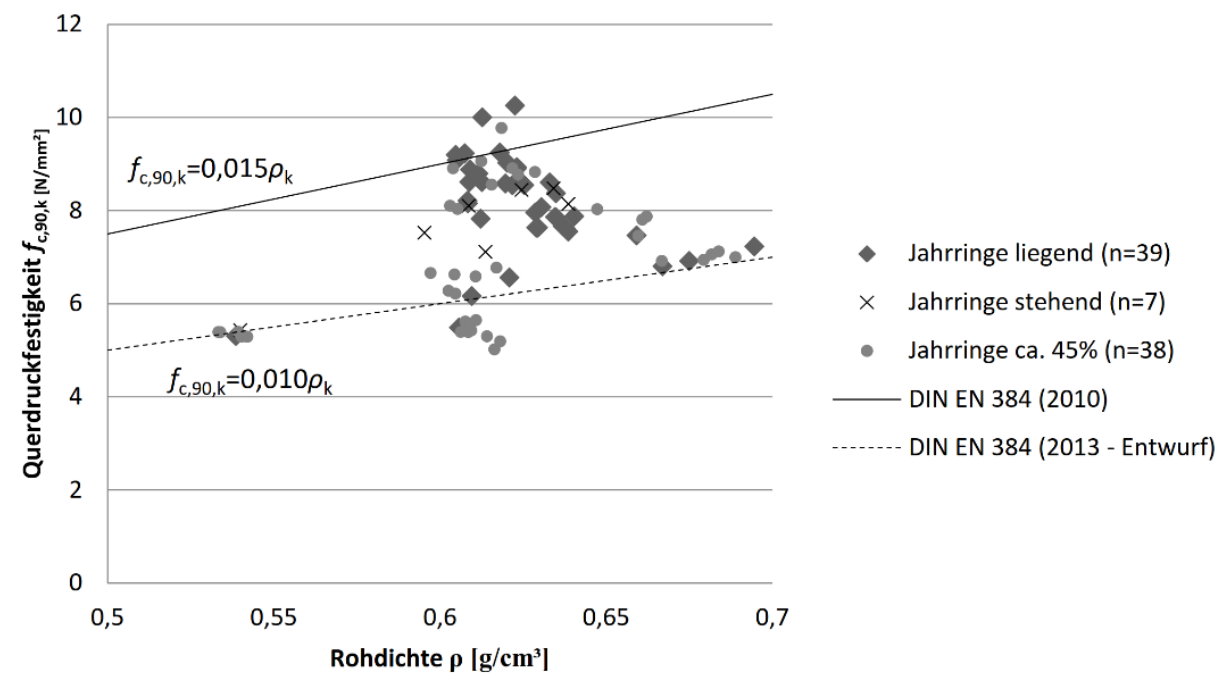

Abb. 2: Querdruckfestigkeit (10\% Kraftabfall) versus Rohdichte getrennt nach Jahrringlage für Esche

Die eingefügte Ausgleichsfunktion spiegelt die Gleichung (1) wieder, welche von der DIN EN 384 [12] als Alternativverfahren zur Bestimmung der Querdruckfestigkeit von Laubholz angegeben wird. Diese Funktion für den charakteristischen Wert der Querdruckfestigkeit überschätzt $93 \%$ der ermittelten Werte für die Esche. Es fällt auf, das die Werte der Prüfkörper mit liegenden Jahrringen über denen der anderen Prüfkörper liegen. Bei Ahorn liegen knapp 60\% der Werte unter der Ausgleichsgerade nach DIN EN 384 [12]. Prüfkörper mit liegenden Jahrringen liegen überwiegend über der Gerade. Eine Abhängigkeit der Querdruckfestigkeit von der Rohdichte wird auch hier nur eingeschränkt bestätigt. Für die Buche zeigen die Ergebnisse vergleichbare Annahmen. Nichtsdestotrotz ist es nicht sinnvoll, die Werte getrennt nach Jahrringlage anzugeben, da in einem Brett in den seltensten Fällen nur eine Jahrringlage vorliegt. Der aktuelle Norm-Entwurf der DIN EN 384 [19] schlägt eine Anpassung der Ausgleichsfunktion der DIN EN 384 [12] vor. Die angepasste Funktion lautet: 


$$
f_{c, 90, k}=0,010 \rho_{k}
$$

Abbildung 2 zeigt, dass nur noch $16 \%$ der Werte für die Querdruckfestigkeit der Esche unter dieser Geraden liegen, also von der Ausgleichsfunktion überschätzt werden. Für Buche sind es noch $28 \%$ und für Ahorn $0 \%$. Die angepasste Funktion (Gleichung 3) stellt somit die passendere Ausgleichsfunktion für alle drei Holzarten dar.

\section{Schlussfolgerung}

Im Rahmen des laufenden Forschungsprojektes werden die Materialkennwerte der DIN EN 338 [1] für die einheimischen Laubholzarten Buche, Esche und Ahorn überprüft. Hierzu werden zunächst die relevanten Normen und Literaturen zusammengetragen und analysiert. Im Anschluss werden experimentelle Untersuchungen durchgeführt und Schlussfolgerungen für die Praxis gezogen. Der vorliegende Beitrag zeigt dieses Vorgehen exemplarische für den Materialkennwert Druckfestigkeit rechtwinklig zur Faserrichtung.

Die experimentellen Untersuchungen werden gemäß DIN EN 408 [2] durchgeführt. Sie zeigen, dass die charakteristischen Druckfestigkeiten der untersuchten Laubhölzer (Vollholz) unter denen der DIN EN 338 [1] liegen. Aktuelle Norm-Entwürfe sowohl für die DIN EN 338 als auch die DIN EN 384 gehen auch von niedrigeren charakteristischen Druckfestigkeiten aus. Eine Anpassung der Bruchdefinition für ringporige Holzarten wie Esche wird überdies vorgeschlagen. Die mittleren Elastizitätsmoduln liegen bei allen untersuchten Hölzern unter Norm- und Literaturwerten. Die Ursachen hierfür werden zurzeit untersucht.

\section{Literatur}

[1] DIN EN 338: Bauholz für tragende Zwecke- Festigkeitsklassen, DIN-Deutsches Institut für Normung e.V., 2010.

[2] DIN EN 408: Holzbauwerke - Bauholz für tragende Zwecke und Brettschichtholz Bestimmung einiger physikalischer und mechanischer Eigenschaften, DIN-Deutsches Institut für Normung e.V., 2012.

[3] DIN 4074-5: Sortierung von Holz nach der Tragfähigkeit- Teil 5: Laubschnittholz, DIN-Deutsches Institut für Normung e.V., 2008.

[4] Niedersächsische Landesforsten: Das LÖWE-Programm - 20 Jahre langfristige ökologische Waldentwicklung, Braunschweig, 2011.

[5] Döring P. und Mantau U.: Standorte der Holzwirtschaft - Sägeindustrie - Einschnitt und Sägenebenprodukte 2010, Universität Hamburg, Zentrum Holzwirtschaft, Arbeitsbereich: Ökonomie der Holz- und Forstwirtschaft, Hamburg, 2012.

[6] Mantau U.: Standorte der Holzwirtschaft, Holzrohstoffmonitoring, Holzwerkstoffindustrie - Kapazitätsentwicklung und Holzrohstoffnutzung im Jahr 2010, Universität Hamburg, Zentrum Holzwirtschaft, Arbeitsbereich Ökonomie der Holz- und Forstwirtschaft, Hamburg, 2012.

[7] Welling J.: Unterschiede zwischen Laub- und Nadelholz und deren Einfluss auf die Verarbeitung und Verwendung,. Johann-Heinrich von Thünen Institut, Institut für Holztechnologie und Holzbiologie, BMEVL-Laubholztagung, Würzburg, 2012.

[8] Aicher S.: Laubholzprodukte \& Anwendungen im Bauwesen - aktueller Stand in Europa, MPA Stuttgart, Otto-Graf-Institut, Ligna 2015: Ressource Laubholz, Hannover, 
2015.

[9] DIN EN 1995-1-1: Eurocode 5: Bemessung und Konstruktion von Holzbauten - Teil 11: Allgemeines - Allgemeine Regeln und Regeln für den Hochbau, DIN-Deutsches Institut für Normung e.V., 2013.

[10] DIN EN 1912: Bauholz für tragende Zwecke - Festigkeitsklassen - Zuordnung von visuellen Sortierklassen und Holzarten, DIN-Deutsches Institut für Normung e.V., 2013.

[11] DIN EN 14081-1: Holzbauwerke - Nach Festigkeit sortiertes Bauholz für tragende Zwecke mit rechteckigem Querschnitt - Teil 1: Allgemeine Anforderungen, DINDeutsches Institut für Normung e.V., 2014.

[12] DIN EN 384: Bauholz für tragende Zwecke - Bestimmung charakteristischer Werte für mechanische Eigenschaften und Rohdichte, DIN-Deutsches Institut für Normung e.V., 2010.

[13] Hübner U.: Mechanische Kenngrößen von Buchen-, Eschen- und Robinienholz für lastabtragende Bauteile, Technische Universität Graz, Institut für Holzbau und Holztechnologie, Dissertation, 2013.

[14] Hübner U.: Höhere Festigkeitseigenschaften von Laubhölzern. Welche Chancen ergeben sich daraus für den Holzbau?, Wiener Leimholz Symposium, Wien, 2014, S. $20-26$.

[15] DIN 52192: Prüfung von Holz; Druckversuch quer zur Faserrichtung, DIN-Deutsches Institut für Normung e.V., 1979.

[16] AITC-119: Standard specifications for structural glued laminated timber of hardwood species, 1996.

[17] Allgemeine bauaufsichtliche Zulassung Nr. Z-9.1-679: BS-Holz aus Buche und BS-Holz Buche-Hybridträger, Antragsteller: Studiengemeinschaft Holzleimbau e. V., Deutsches Institut für Bautechnik, 2013.

[18] Allgemeine bauaufsichtliche Zulassung Nr. Z-9.1-704: VIGAM Brettschichtholz aus Eiche, Antragsteller: Elaborados y Fabricados Gamiz S.A., Spanien, Deutsches Institut für Bautechnik, 2012.

[19] DIN EN 384 [Entwurf]: Bauholz für tragende Zwecke - Bestimmung charakteristischer Werte für mechanische Eigenschaften und Rohdichte, DIN-Deutsches Institut für Normung e.V., 2013. 


\title{
Curriculum vitae
}

\author{
Personal details \\ Name Schlotzhauer, Philipp \\ $\begin{array}{ll} & \text { Lappstraße 2 } \\ \text { Address } & \text { 37133 Friedland }\end{array}$ \\ Germany \\ Place of birth \\ Eisenach, Germany \\ Date of birth \\ $09 / 21 / 1985$
}

\section{University and school education}

2012 - today

- University of Göttingen

- Ph.D.-student "Wood Biology and Wood Technology"

- special emphasis on "hardwoods in construction"

$2010-2012$

$2006-2010$

until 2005

- University of Göttingen

- Student „Tropical and International Forestry (TIF)“

- completion September 2012 with University degree „Master of Science“

- University of Göttingen

- Student "Forestry and Forest Ecology"

- completion March 2010 with University degree "Bachelor of Science"

- Philipp-Melanchthon-Gymnasium Gerstungen

- completion June 2005 with general matriculation 


\section{Work experience and internships}

Mai - September 2011

2005-2010

October 2007 - April 2008

$2007-2012$

Awards and scholarships

2014

2012

2010-2012
- GIZ, Ecuador

- internship and data collection for master thesis (value chain analysis wood products from the Amazon basin)

- work in wood construction

- Staats Constructions (USA), Schambach Holzverarbeitung (Germany) and Andre Görlach Holzverarbeitung (MAC Holzhaus, Germany)

- Arbofilia: NGO (Costa Rica)

- internship

- field work

- University of Göttingen: Dept. Ecoinformatics, Biometrics and Forest Growth

- $\quad$ student assistant

- "Best student presentation" award at conference "10th Meeting: Northern European Network for Wood Science \& Engineering (WSE)"

- "Sayn-Wittgenstein Forstlicher Förderpreis 2012" for best "Masters of Science" degree of the Faculty of Forest Sciences and Forest Ecology in the year 2012

- recipient of the scholarship of the German National Academic Foundation 